\title{
Archeological Impact Evaluations and Surveys in the Texas Department of Transportation's Abilene, Austin, Brownwood, Bryan, Fort Worth, Waco, and Yoakum Districts, 2001-2003
}

Ross C. Fields

Prewitt and Associates, Inc.

Karl W. Kibler

Cross Timbers Geoarcheological Services

E. Frances Gadus

Prewitt and Associates, Inc.

Douglas K. Boyd

Prewitt and Associates, Inc.

Timothy B. Griffith

Prewitt and Associates, Inc.

Follow this and additional works at: https://scholarworks.sfasu.edu/ita

Part of the American Material Culture Commons, Archaeological Anthropology Commons, Environmental Studies Commons, Other American Studies Commons, Other Arts and Humanities Commons, Other History of Art, Architecture, and Archaeology Commons, and the United States History Commons

Tell us how this article helped you.

This Article is brought to you for free and open access by the Center for Regional Heritage Research at SFA ScholarWorks. It has been accepted for inclusion in Index of Texas Archaeology: Open Access Gray Literature from the Lone Star State by an authorized editor of SFA ScholarWorks. For more information, please contact cdsscholarworks@sfasu.edu. 


\section{Archeological Impact Evaluations and Surveys in the Texas Department of}

Transportation's Abilene, Austin, Brownwood, Bryan, Fort Worth, Waco, and Yoakum Districts, 2001-2003

Creative Commons License

(c) $(1) \Theta$

This work is licensed under a Creative Commons Attribution-NonCommercial-No Derivative Works 4.0 International License. 


\title{
ARCHEOLOGICAL IMPACT EVALUATIONS AND SURVEYS IN THE TEXAS DEPARTMENT OF TRANSPORTATION'S ABILENE, AUSTIN, BROWNWOOD, BRYAN, FORT WORTH, WACO, AND YOAKUM DISTRICTS, 2001-2003
}

\author{
by \\ Ross C. Fields \\ Karl W. Kibler \\ E. Frances Gadus \\ Douglas K. Boyd \\ and \\ Timothy B. Griffith \\ with contributions by \\ Christopher W. Ringstaff \\ Patrick McLoughlin \\ Corey Crawford \\ Stephen M. Thompson \\ and \\ Cory J. Broehm
}

Principal Investigator: Ross C. Fields

REPORTS OF INVESTIGATIONS, NUMBER 143

Prewitt and Associates, Inc.

Cultural Resources Services

Austin, Texas

\author{
ARCHEOLOGICAL STUDIES PROGRAM, REPORT NO. 83 \\ Texas Department of Transportation \\ Environmental Affairs Division
}

November 2005

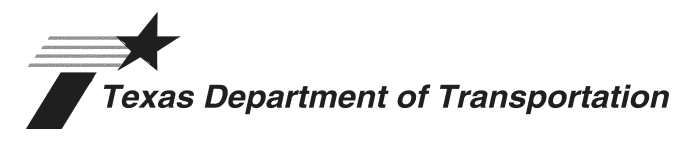

TEXAS ANTIQUITIES PERMIT NO. 2718 


\title{
ARCHEOLOGICAL IMPACT EVALUATIONS AND SURVEYS IN THE TEXAS DEPARTMENT OF TRANSPORTATION'S ABILENE, AUSTIN, BROWNWOOD, BRYAN, FORT WORTH, WACO, AND YOAKUM DISTRICTS, 2001-2003
}

Copyright $@ 2005$

Texas Department of Transportation (TxDOT) and Prewitt and Associates, Inc. (PAI)

TxDOT and PAI jointly own all rights, title, and interest in and to all data and other information developed for this project under Contract 572XXSA002. Brief passages from this publication may be reproduced without permission provided that credit is given to TxDOT and PAI. Permission to reprint an entire chapter, section, figures or tables must be obtained in advance from the Supervisor of the Archeological Studies

Program, Environmental Affairs Division, Texas Department of Transportation, 125 East 11th Street, Austin, Texas, 78701. Copies of this publication have been deposited with the Texas State Library in compliance with the State Depository Requirement.

\author{
jointly published by the \\ Texas Department of Transportation \\ Environmental Affairs Division \\ Archeological Studies Program \\ G. Lain Ellis, Ph.D., Supervisor \\ Archeological Studies Program, Report No. 83 \\ $\mathrm{Al}$ McGraw, Series Editor \\ and \\ Prewitt and Associates, Inc. \\ Cultural Resources Services \\ Austin, Texas \\ Reports of Investigations, Number 143
}

Printed by Morgan Printing in Austin, Texas

ISBN 1-930788-53-3 


\section{TABLE OF CONTENTS}

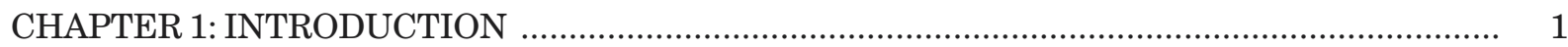

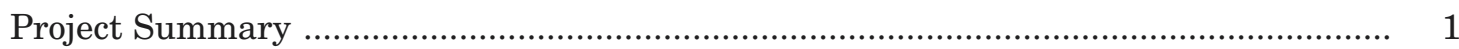

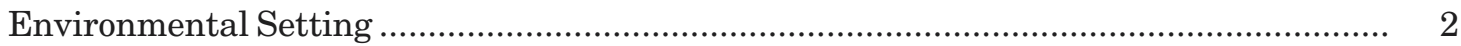

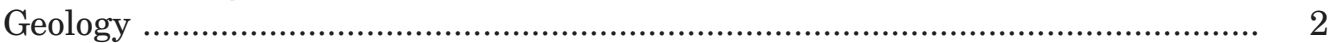

Natural Regions and Vegetation ................................................................. 3

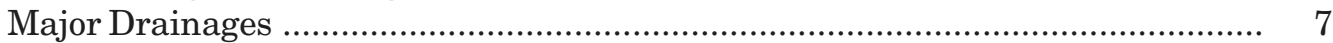

CHAPTER 2: SYNOPSIS OF NATIVE AMERICAN CULTURE HISTORY ............................... 11

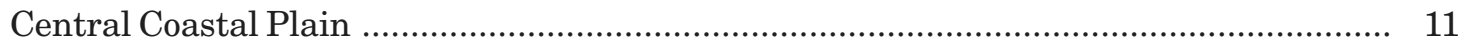

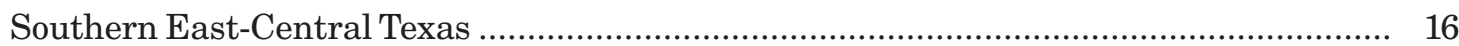

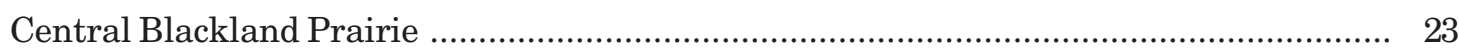

Northern and Northeastern Portions of Central Texas ................................................ 25

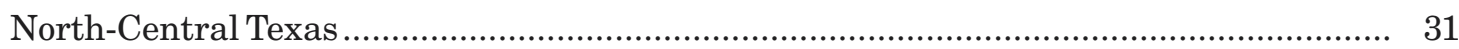

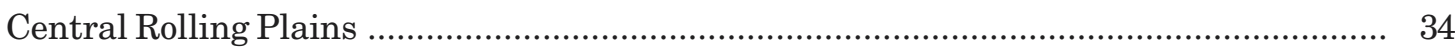

CHAPTER 3: SUMMARY OF IMPACT EVALUATIONS AND SURVEYS ................................. 43

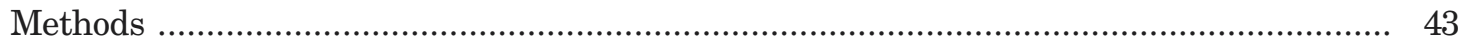

Synopsis of Work Authorizations ….......................................................................... 74

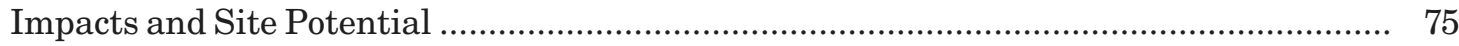

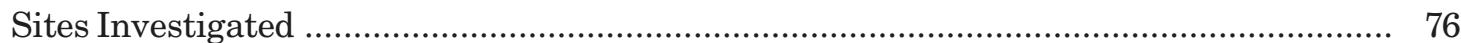

Work Authorization 3: 41WM646, 41WM1008, and 41WM1009 _....................... 101

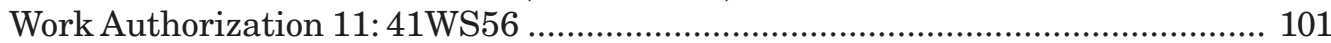

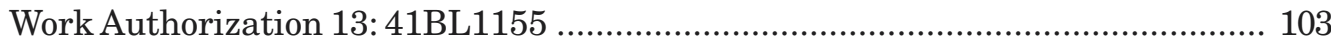

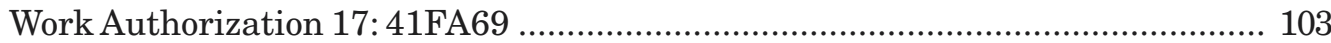

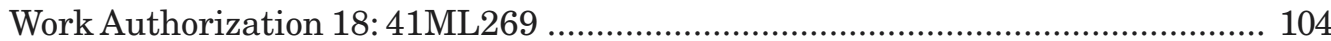

Work Authorization 20: 41MA26 .................................................................. 104

Work Authorizations 25 and 29: 41CJ93 and41CJ94 _........................................ 104

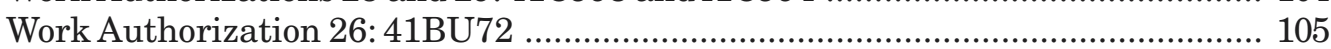

Work Authorization 30: Marked Historic Grave ……......................................... 106

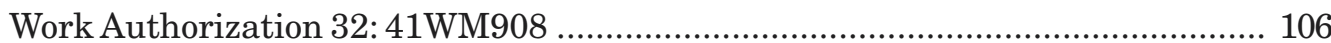

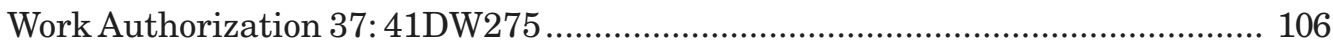

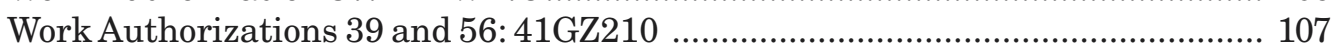

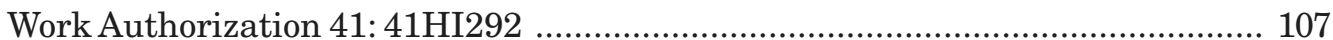

Work Authorization 47: 41BU51, 41BU54, and 41BU75 .................................. 108

Work Authorization 54: 41TV2022 and 41TV2023 ............................................ 109

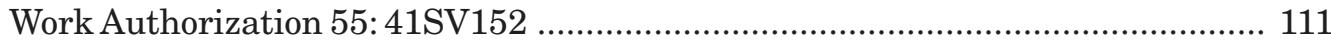




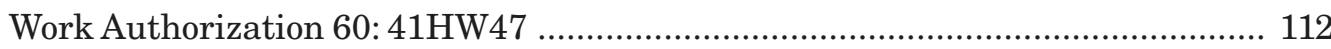

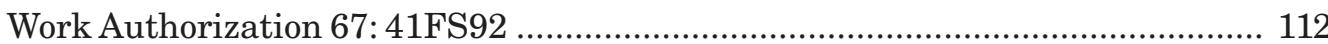

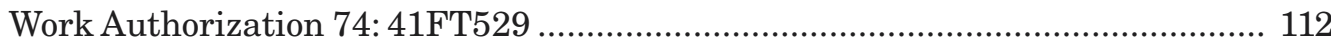

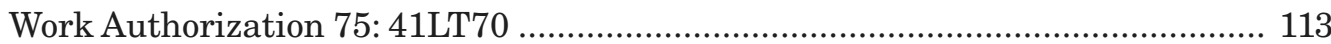

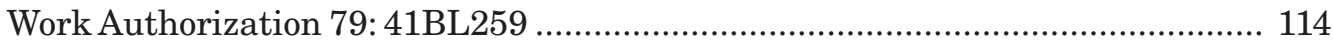

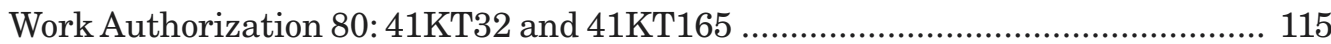

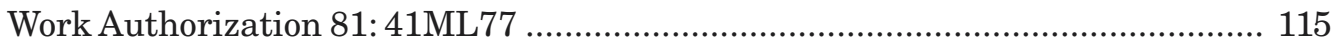

Work Authorization 81: 41ML24, 41ML28, and 41ML80 ................................. 116

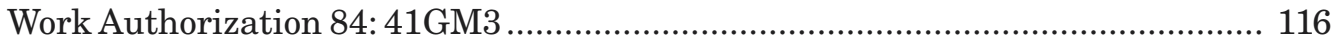

Work Authorizations 89 and 99: Isolated Historic-age Well and

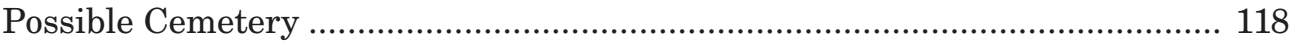

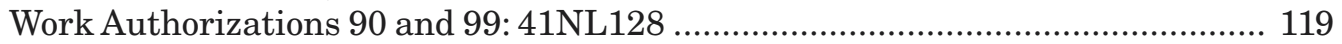

Work Authorization 91: 41WM235 and 41WM774 _......................................... 120

Work Authorization 91: 41TV1134 and 41TV1135 ........................................... 121

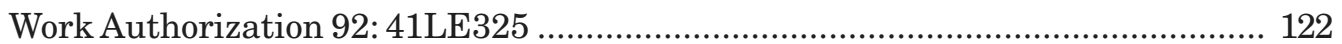

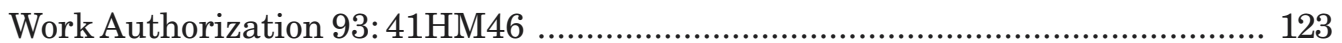

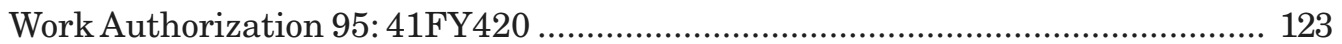

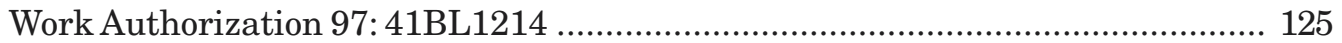

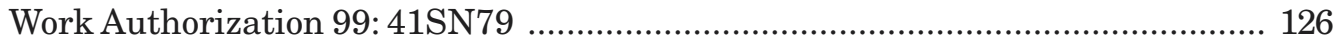

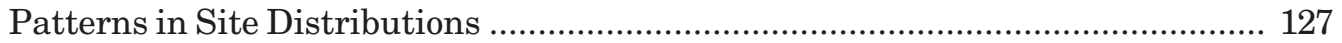

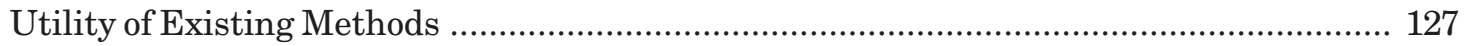

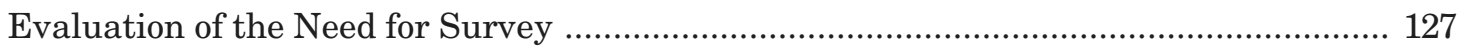

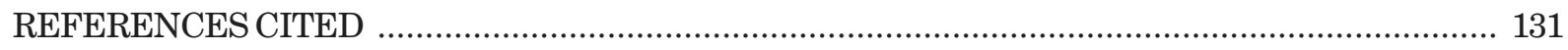

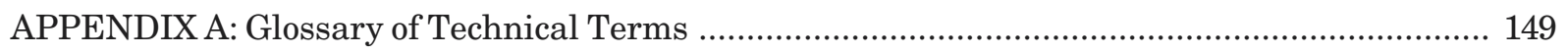

APPENDIX B: Letters and Letter Reports for Impact Evaluations and Surveys ........................ 153 


\section{LIST OF FIGURES}

1. Locations of the Abilene, Austin, Brownwood, Bryan, Fort Worth, Waco, and Yoakum Districts in relation to natural regions

2. Major drainages in the Abilene, Austin, Brownwood, Bryan, Fort Worth, Waco, and Yoakum Districts

3. Map showing the six culture history summary areas ….............................................. 12

4. Map of the study area showing the locations of all Impact Evaluations and Surveys

5. Schematic cross section of a bridge approach showing common disturbance factors

\section{LIST OF TABLES}

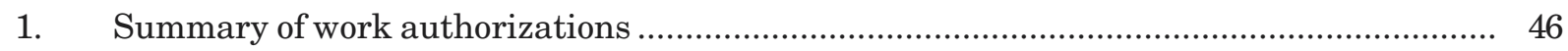

2. Summary of existing impacts by work authorization ............................................... 77

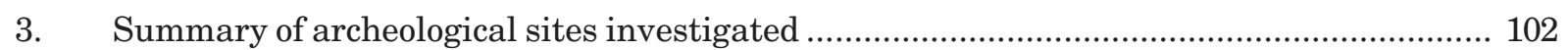




\begin{abstract}
This document constitutes the final report of work done by Prewitt and Associates, Inc. (PAI), under a contract from the Texas Department of Transportation (TxDOT) to provide archeological services in seven TxDOT districts-Abilene, Austin, Brownwood, Bryan, Fort Worth, Waco, and Yoakum. Under this contract, PAI completed Impact Evaluations and Surveys to assist TxDOT in meeting the requirements of their Memorandum of Understanding with the Texas Historical Commission and a Programmatic Agreement among the Advisory Council on Historic Preservation, the Federal Highway Administration, the Texas Historical Commission, and TxDOT. The contract began on 21 September 2001, and the last work authorization was issued on 15 September 2003. During those two years, fieldwork was done under 96 work authorizations.

The 97 work authorizations consisted of 94 Impact Evaluations, 74 Surveys, and 14 Surveys with Geoarcheological Evaluation. Combined, these work authorizations entailed efforts at 128 bridge replacements, 40 road realignments or widening projects (many also involving bridge replacements), 5 new road construction projects, 4 hike-and-bike trail construction projects, 4 rest area construction projects, 3 projects involving upgrades to 9 existing bridges or culverts, 2 projects where new borrow pits are planned, 2 projects involving relocation of historic bridges to public parks, 1 project involving construction of 2 new bridges, 1 project involving replacement of an interstate highway interchange, and 1 project involving establishment of a wetland mitigation area. During completion of these work authorizations, 43 newly discovered or previously recorded archeological sites were investigated, although in the case of 14 previously recorded sites, no archeological remains were observed in the areas that will be affected by the proposed Transportation Activities.

Twenty-three of the Impact Evaluations led to recommendations that survey could be needed before construction, in some cases depending on whether new right of way would be required. Based on the limited potential for sites with good integrity, the other 71 Impact Evaluations resulted in recommendations that no survey be required before construction. Twenty-two of the Surveys investigated a total of 17 newly recorded and 9 previously recorded sites. Of these 26 sites, 6 were recommended for testing to assess eligibility for listing in the National Register of Historic Places and designation as State Archeological Landmarks. The other 82 Surveys either did not find any archeological sites or investigated sites that could be assessed as ineligible for National Register listing and State Archeological Landmark designation using the survey data. All artifacts collected and records generated by projects done under this contract are curated at the Texas Archeological Research Laboratory (TARL), The University of Texas at Austin. Artifacts were collected from four sites. Those from 41GM3 are from state-owned lands and thus are curated in a held-in-trust status at TARL. The artifacts from 41BU51, 41BU54, and 41LE325 are from private lands and are curated in a non-held-in-trust status.
\end{abstract}




\section{ACKNOWLEDGMENTS}

A number of people contributed to the successful completion of this project. Dr. G. Lain Ellis managed the contract for the Archeological Studies Program, Environmental Affairs Division, Texas Department of Transportation, with the oversight of Owen Lindauer and Nancy Kenmotsu and the assistance of Jon Budd, Cindy Tennis, Tim Meade, and G. R. Dennis Price. At Prewitt and Associates, Ross C. Fields served as principal investigator, and Douglas K. Boyd was the quality control officer. Christopher W. Ringstaff, Patrick McLoughlin, Karl W. Kibler, E. Frances Gadus, Stephen M. Thompson, Timothy B. Griffith, and Cory J. Broehm served as project archeologists. Mr. Kibler and Corey Crawford filled the position of project geoarcheologist. These people performed most of the fieldwork and were responsible for writing most of the reports on individual work authorizations included as Appendix B; the site descriptions included in the body of the report are extracted from the work authorization reports. Mr. Kibler prepared the Environmental Setting section of the report and one of the culture history summaries (Northern and Northeastern Portions of Central Texas). Ms. Gadus wrote the culture history summaries for the Central Coastal Plain and North-Central Texas. Mr. Boyd and Mr. Griffith co-authored the culture history summary for the Central Rolling Plains. Mr. Fields wrote the remainder of the report. Support at Prewitt and Associates was provided by Karen M. Gardner (laboratory supervision, photograph cataloging, and curation); Brian J. Wootan and Sandra L. Hannum (production of graphics); and Audra L. Pineda and Jane Sevier (report editing and production). 



\section{INTRODUCTION}

\section{PROJECT SUMMARY}

This document constitutes the final report of work done by Prewitt and Associates, Inc. (PAI), under a contract (\#572XXSA002) with the Texas Department of Transportation (TxDOT) to provide archeological services in seven TxDOT Districts-Abilene, Austin, Brownwood, Bryan, Fort Worth, Waco, and Yoakum-stretching from the central Texas coast northward and northwestward into the east-central, central, north-central, and northwestern parts of the state. The contract began on 21 September 2001, and the last work authorization, for preparation of this report, was issued on 15 September 2003. During those two years, fieldwork was done under 96 work authorizations. Texas Antiquities Permit No. 2718 was issued by the Texas Historical Commission to cover the work done under this contract.

Under this contract, PAI completed Impact Evaluations and Surveys to assist TxDOT in meeting the requirements of their Memorandum of Understanding with the Texas Historical Commission and a Programmatic Agreement among the Advisory Council on Historic Preservation, the Federal Highway Administration, the Texas Historical Commission, and TxDOT. TxDOT defines Impact Evaluations as "on-site inspection ... documenting existing impacts or other conditions which may preclude the presence of intact archeological deposits within the project area for a proposed Transportation Activity." Impact Evaluations are thus an initial step to determine whether survey of a particular area is warranted, given the anticipated effects of the project, the existing level of disturbance, and the likelihood of archeological deposits in good context.
TxDOT defines Surveys as "archeological field work ... of a proposed Transportation Activity to locate archeological remains, if any, including on-foot examination of the surface, shovel testing, and subsurface trenching by mechanical means where appropriate." As described below, PAI completed 98 work authorizations involving 94 Impact Evaluations, 88 Surveys, and 1 work authorization to prepare this report. Fourteen of the surveys included geoarcheological evaluations, and 74 did not. Most of these projects focused on locations where bridges will be replaced. Other kinds of Transportation Activities included road-widening projects, road realignments, construction of new roads or bridges, construction of hike-and-bike trails, construction of new rest areas, new borrow pits, relocation of historic-age bridges, upgrading of existing bridges and culverts, creation of a wetland mitigation area, construction of a new railroad overpass, and reconstruction of a highway interchange.

During completion of these work authorizations, 43 newly discovered or previously recorded archeological sites were investigated, although in the case of 14 previously recorded sites, no archeological sites were investigated, although in the case of 14 previously recorded sites, no archeological remains were observied in the areas that will be affected by the proposed Transportation Activities. All artifacts collected and records generated by projects done under this contract are curated at the Texas Archeological Research Laboratory (TARL), The University of Texas at Austin. Artifacts were collected from four sites. Those from 41GM3 are from state-owned lands and thus are curated in a held-in-trust status at TARL. The artifacts from 41BU51, 41BU54, and 41LE325 are from 
private lands and are curated in non-held-intrust status.

The body of this report consists of three chapters. A brief characterization of the environmental setting of the seven TxDOT districts follows this introduction. Six synopses of $\mathrm{Na}-$ tive American culture histories are presented in Chapter 2. The first deals with the Gulf Coast Prairies and Marshes of the central coastal plain and encompasses much of the Yoakum District. The second focuses on the southern part of the Oak Woodlands of east-central Texas and covers the northern part of the Yoakum District, most of the Bryan District, and the eastern edges of the Austin and Waco Districts. The third looks at the central Blackland Prairie in the eastern Waco and Austin Districts and the western Bryan District. The fourth deals with the northern and northeastern portions of central Texasthe eastern Edwards Plateau and adjacent Blackland Prairie margin, the Llano Uplift, the southern parts of the Grand Prairie and the Eastern and Western Cross Timbers, and the southern edge of the Rolling Plains-and encompasses the central and western parts of the Austin and Waco Districts, the southern part of the Brownwood District, and the southern edge of the Fort Worth District. The fifth discusses the northern Grand Prairie and Eastern and Western Cross Timbers and adjacent eastern margin of the Rolling Plains of north-central Texas; most of the Fort Worth District is in this region. The final culture history section deals with the central Rolling Plains of northwest Texas, encompassing the Abilene District and the northern part of the Brownwood District. These synopses do not include histories of use by EuroAmericans because such overviews are not feasible here for such large areas. Historical background informatin can be found for specific project areas, however, in The New Handbook of Texas.

After the culture history synopses is a chapter summarizing the work done under this contract that discusses the methods employed in the Impact Evaluations and Surveys and evaluates their effectiveness. It also presents tables listing the Impact Evaluations and Surveys and their topographic and geologic settings, soils, land use, and presence or absence of archeological sites. Existing disturbances that affected the potential of project areas to contain sites with sufficient integrity to be eligible for National Register of
Historic Places listing or State Archeological Landmark designation are listed and discussed. The sites investigated are described next. This section also provides an evaluation of the need for survey based on the results of this project. A references cited section and two appendixes follow the body of the report. Appendix A is a glossary of technical terms, and Appendix B (on CD-ROM and included only with select copies) contains the letters and reports submitted to TxDOT for all Impact Evaluations and Surveys done under the contract.

\section{ENVIRONMENTAL SETTING}

\section{Geology}

The Abilene, Austin, Brownwood, Bryan, Fort Worth, Waco, and Yoakum Districts cover a 71-county area in west-central and central Texas and along the central Texas coast. The southeastern portion of this seven-district area lies within the Western Gulf Coastal Plain physiographic province, the western and northwestern portions lie within the Great Plains province, and a small part of the northern portion lies in the Osage section of the Central Lowlands province (Fenneman 1931, 1938). The intersection of these three physiographic provinces has had an interesting and dynamic geologic history (see Spearing 1991).

Geologically, the seven-district area straddles a deep-seated fracture zone and site of past orogenic events that separates the stable continental interior to the west from the subsiding Gulf basin to the east and southeast (Hayward 1988a, 1988b). The early geologic history of the area is evidenced in the rocks in the northwest portion of the Austin District and the southern part of the Brownwood District. Tectonic events during the Precambrian metamorphosed sediments deposited along the margin of the continent into gneiss and schists, which were later penetrated by intrusive granitic rocks. Marine transgression during the early Paleozoic followed, and sandy sediments were deposited along the edge of the sea. Farther to the east and southeast, limestones and dolomites were deposited in the deeper open waters. Continued transgression covered the earlier rock units with extensive dolomites, limestones, sandstones, and shales, which now form the tilted flanks of the Llano Uplift. Toward the end 
of the Paleozoic (Pennsylvanian), the Ouachita Mountains rose along the margin of the continent because of tectonic events related to formation of the supercontinent Pangaea. The rise of the Ouachita Mountains along this zone in the Paleozoic caused deposition of clastic sediments and carbonates on a broad shelf along the margin of the Permian Basin located southwest of the seven-district area. These sediments formed the Pennsylvanian and Permian rock units of the western and northwestern parts of the seven-district area. These sandstone, mudstone, and limestone units dip and become progressively younger toward the basin.

Later during the Cretaceous period as the Gulf of Mexico formed, clastic sediments and carbonates were deposited over the worn-down Ouachita Mountains and late Paleozoic rocks, and along the broad marginal shelf of the Gulf basin. The Lower Cretaceous sandstones, mudstones, limestones, and marls found throughout parts of the Abilene, Austin, Brownwood, Fort Worth, and Waco Districts represent cycles of marine transgression and regression throughout the period. By Upper Cretaceous times, infilling of the Gulf basin and shoreline progradation predominated, as evidenced by Upper Cretaceous sandstones and mudstones throughout the eastern parts of the Austin, Fort Worth, and Waco Districts. Marine regression and shoreline progradation continued during the Tertiary and Quaternary and are represented by various sandstone and mudstone units present throughout the Bryan and Yoakum Districts and the eastern parts of the Austin and Waco Districts. Also at this time (Miocene), another tectonic event along the fracture zone uplifted the Edwards Plateau, forming the Balcones Escarpment, which traverses the Austin District.

\section{Natural Regions and Vegetation}

The different rock units have a major influence on the topography, flora, and hydrology across the seven-district area. Seventeen different natural subregions lie within the area in part because of these lithological variations (Figure 1). These 17 subregions are the Mixed PineHardwood Forest of the Piney Woods region; the Oak Woodlands, Eastern Cross Timbers, and Western Cross Timbers of the Oak Woods and
Prairies region; the Blackland Prairie and Grand Prairie of the Blackland Prairies region; the Dunes/Barrier, Estuarine Zone, and Upland Prairies and Woods of the Gulf Coast Prairies and Marshes region; the Brush Country of the South Texas Brush Country region; the Live Oak-Mesquite Savanna, Balcones Canyonlands, and Lampasas Cut Plain of the Edwards Plateau region; the Llano Uplift region; the Escarpment Breaks and Mesquite Plains of the Rolling Plains region; and the High Plains region (LBJ School of Public Affairs 1978).

The Mixed Pine-Hardwood Forest subregion covers a small portion of the eastern Bryan District. The Oak Woodlands subregion encompasses most of the Bryan District, the eastern margins of the Austin and Waco Districts, and the northwestern margin of the Yoakum District. The Eastern and Western Cross Timbers cover the eastern and central parts of the Fort Worth District, small parts of the northern Waco District, and the east-central part of the Brownwood District. The Blackland Prairie subregion covers the eastern parts of the Fort Worth, Waco, and Austin Districts; small portions of the Bryan District; and the northern and western portions of the Yoakum District, and the Grand Prairie subregion extends through the central and eastern portions of the Waco and Fort Worth Districts. The Upland Prairies and Woods subregion covers most of the Yoakum District, and The Dunes/Barrier and Estuarine subregions encompass the bays, estuaries, and barrier islands of the district.

The Brush Country subregion covers a small part of the western portion of the Yoakum District. The Lampasas Cut Plain subregion is limited to the southwestern portion of the Waco District, a small part of the northern margin of the Austin District, the southeastern and central portions of the Brownwood District, and the extreme southeastern corner of the Abilene District. The Balcones Canyonlands and Live Oak-Mesquite Savanna compose much of the western part of the Austin District. The Llano Uplift is limited to the northwestern portion of the Austin District and southern part of the Brownwood District. The Mesquite Plains subregion covers most of the Abilene District, the northern and western portions of the Brownwood District, and the northwestern corner of the Fort Worth District. The Escarpment Breaks subregion and the High Plains region 


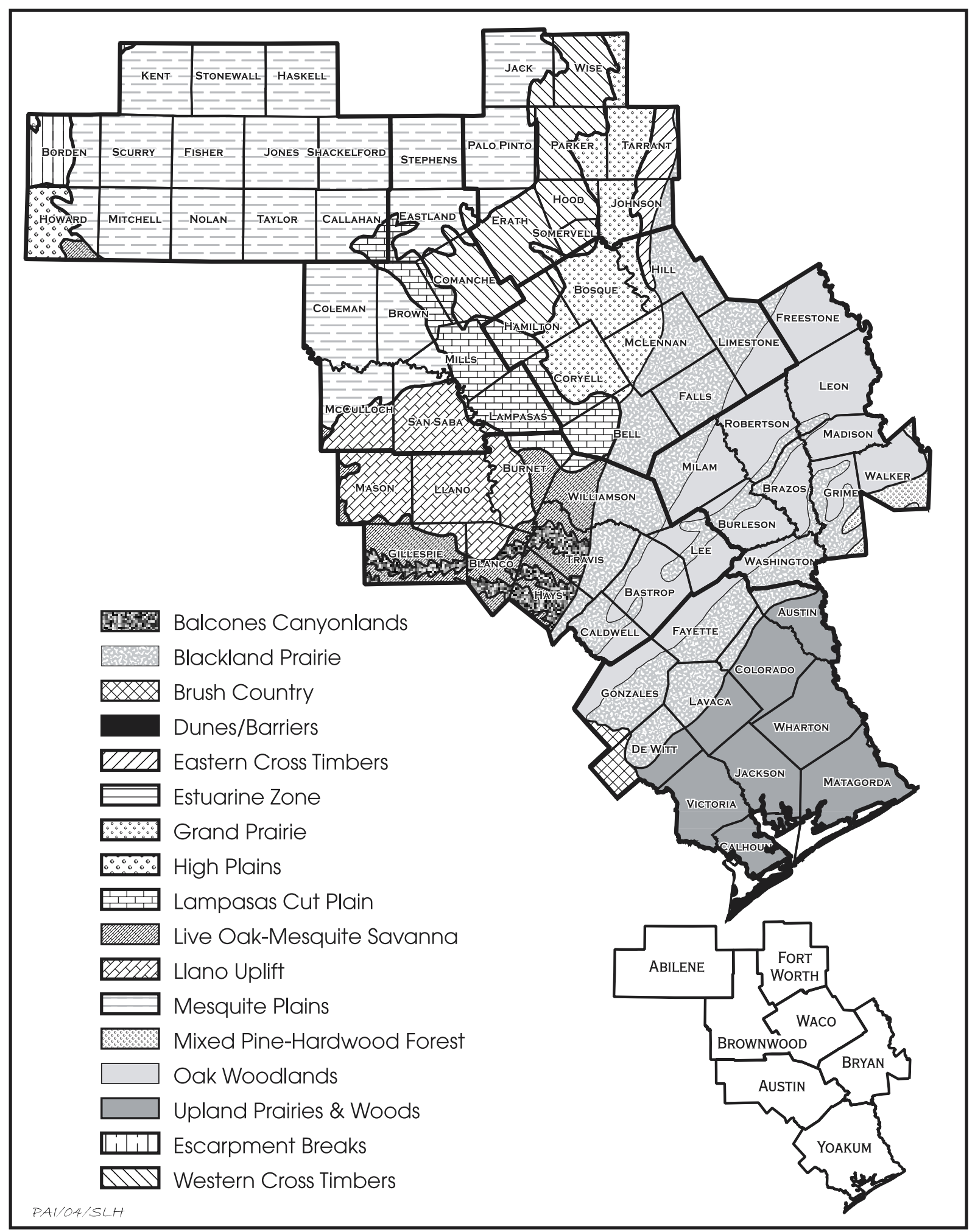

Figure 1. Locations of the Abilene, Austin, Brownwood, Bryan, Fort Worth, Waco, and Yoakum Districts in relation to natural regions. 
are limited to the extreme western portion of the Abilene District.

The modern plant communities vary from subregion to subregion. The Mixed PineHardwood Forest consists of deciduous forests (greater than 60 percent canopy cover) of loblolly pine, shortleaf pine, overcup oak, swamp chestnut oak, willow oak, water oak, sweetgum, and sweetbay (Diamond et al. 1987). Deciduous woodlands (26-60 percent canopy cover) of bluejack oak and pine and swamp communities of bald cypress, buttonbush, and water elm are also a part of the Mixed Pine-Hardwood Forest.

The Oak Woodlands subregion consists of overcup oak, post oak, and black hickory deciduous forests and bluejack oak, pine, post oak, and blackjack oak deciduous woodlands (Diamond et al. 1987). The flora of the Eastern Cross Timbers consists of deciduous forests of post oak and black hickory and post oak and blackjack oak woodlands, and the Western Cross Timbers are primarily post oak and blackjack oak deciduous woodlands (Diamond et al. 1987).

The Blackland Prairie subregion consists of tall grasslands (dominants greater than $1 \mathrm{~m}$ tall), primarily little bluestem and Indiangrass, with riparian deciduous forests of sugarberry and elm (Diamond et al. 1987). The Grand Prairie subregion is a mixed grass prairie dominated by little bluestem and containing isolated live oak mottes, junipers, and mesquite savannas (Hayward et al. 1996).

In the Dunes/Barrier subregion, tall grasslands of seacoast bluestem, forb-dominated communities of cenicilla and beach morning glory, and marshes (herbaceous-dominated wetlands) of marshhay cordgrass, smooth cordgrass, gulf cordgrass, rushes, and sedges prevail, and the Estuarine Zone consists of marshes of the same cordgrass, rush, and sedge species (Diamond et al. 1987). The Upland Prairies and Woods subregion consists of water oak and live oak forests; pecan, mesquite, huisache, post oak, and live oak woodlands; tall grasslands of brownseed paspalum, little bluestem, Indiangrass, gamagrass, and switchgrass; marshes of gulf cordgrass, marshhay cordgrass, rushes, and sedges; and swamps (forest or shrub-dominated wetlands) of buttonbush.

The Brush Country subregion consists of deciduous forests of hackberry and elm, deciduous woodlands of mesquite and huisache, and deciduous shrublands (dominants $0.5-3.0 \mathrm{~m}$ tall providing 26 percent or more canopy cover) of blackbrush and fern acacia (Diamond et al. 1987). Evergreen shrublands of ceniza and medium-tall grasslands (dominants $0.5-1.0 \mathrm{~m}$ tall) of cane bluestem are also part of the Brush Country floral mosaic.

Plant communities of the Lampasas Cut Plain include deciduous woodlands of Texas oak and riparian deciduous forests of sugarberry and elm (Diamond et al. 1987). The flora of the Balcones Escarpment form a complex mosaic of bald cypress, sycamore, sugarberry, and elm deciduous forests; juniper and live oak evergreen woodlands; and lacey and Texas oak deciduous woodlands. The Live Oak-Mesquite Savanna of the Edwards Plateau consists of riparian forests of sugarberry and elm, evergreen woodlands of juniper and live oak, deciduous woodlands of lacey and plateau live oak, and deciduous shrublands (greater than 26 percent canopy cover of shrubs less than $0.5 \mathrm{~m}$ tall) of Mohr's shin oak. Short (dominants less than $0.5 \mathrm{~m}$ ) to medium-tall (dominants $0.5-1.0 \mathrm{~m}$ ) grasslands of curlymesquite, sideoats grama, blue grama, and buffalograss also are part of the Live Oak-Mesquite Savanna plant community. Riparian deciduous forests of sugarberry and elm and deciduous woodlands of plateau live oak characterize the Llano Uplift region.

The Mesquite Plains subregion of the Rolling Plains contains riparian deciduous forests of sugarberry and elm and evergreen shrublands of Harvard shin oak, oneseed juniper, redberry juniper, and sandsage (Diamond et al. 1987). Deciduous shrublands of Mohr's shin oak, medium-tall grasslands of little bluestem and sideoats grama, and marshes of saltgrass also are part of the plant community. Floral communities of the Escarpment Breaks subregion include riparian deciduous forests of sugarberry and elm; evergreen woodlands of Rocky Mountain juniper; evergreen shrublands of Harvard shin oak, oneseed juniper, and redberry juniper; deciduous shrublands of Mohr's shin oak; and marshes of saltgrass.

The High Plains region consists of Harvard shin oak, oneseed juniper, redberry juniper, and sandsage evergreen shrublands; medium-tall grasslands of sideoats grama; and short grasslands of blue grama, buffalograss, and tobosa (Diamond et al. 1987). 


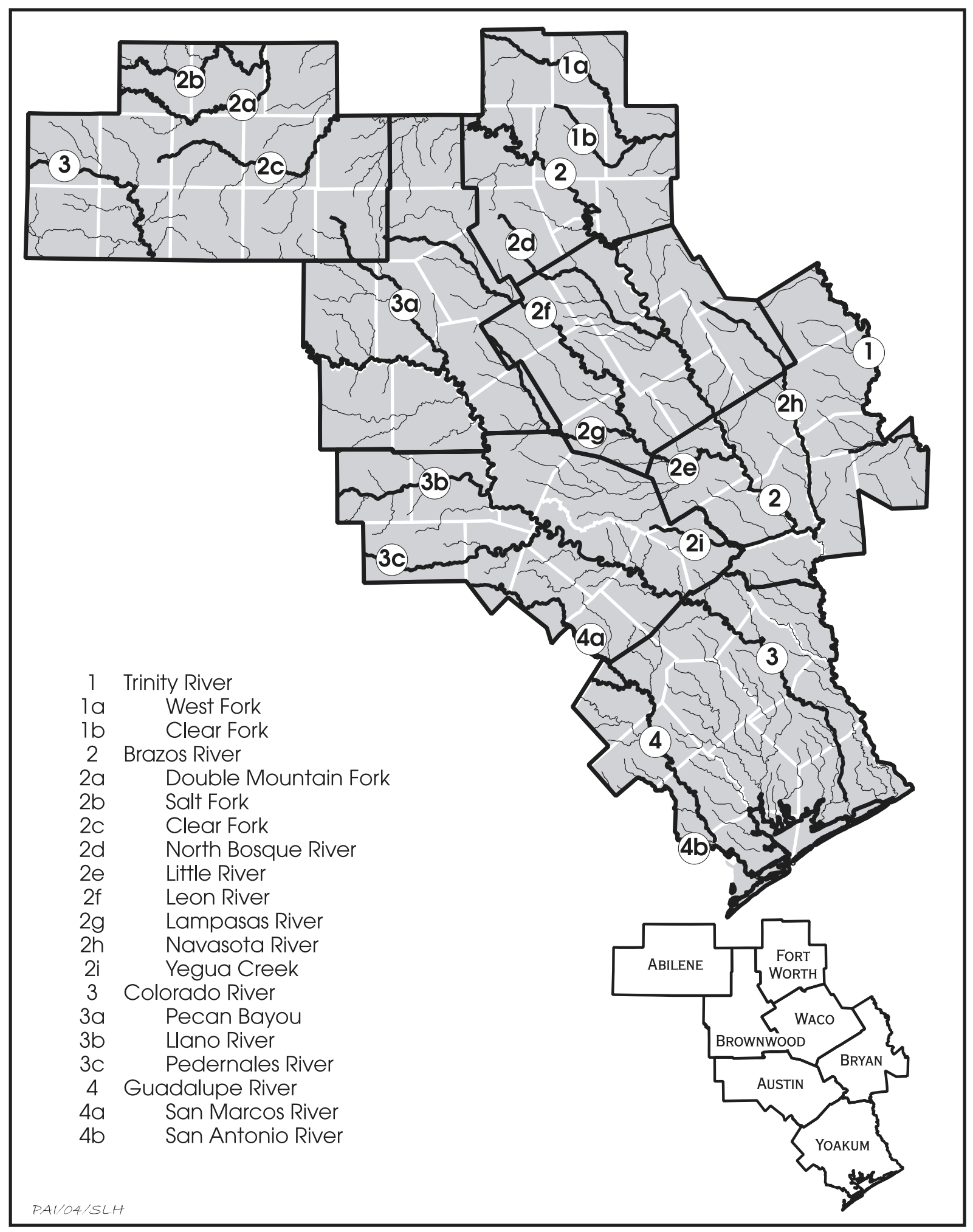

Figure 2. Major drainages in the Abilene, Austin, Brownwood, Bryan, Fort Worth, Waco, and Yoakum Districts. 


\section{Major Drainages}

The major drainages within the sevendistrict area are the Trinity, Brazos, Colorado, and Guadalupe Rivers (Figure 2). Two major branches of the Trinity River, the West Fork and Clear Fork, flow through the Fort Worth District and merge with the Elm Fork to form the Trinity River just east of the Fort Worth District. From here the Trinity River flows southeast outside the seven-district area, reentering the Bryan District at Freestone County and continuing to flow southeast along the eastern edge of the district. It leaves the Bryan District as it enters Lake Livingston and exits Walker County. Within the Bryan District, the Trinity River floodplain averages $5-6 \mathrm{~km}$ in width and is flanked by large segments of Pleistocene terraces (Proctor et al. 1970; Shelby et al. 1968). Holocene alluvium is also mapped along several of the larger tributaries of the Trinity River, including Richland Creek, Tehuacana Creek, Upper Keechi Creek, Lower Keechi Creek, Boggy Creek, and Bedias Creek.

Within the Fort Worth District, the branches of the Trinity River all contain Holocene alluvium below floodplains that are up to $1 \mathrm{~km}$ wide. One of the larger branches, the West Fork, has a narrow floodplain (less than $1 \mathrm{~km}$ ), and no Pleistocene terraces are mapped as it flows southeast across Jack and Wise Counties (Hentz and Brown 1987; McGowen et al. 1967). But as it enters Tarrant County, it flows south and then abruptly turns eastward to flow through the city of Fort Worth; it is along this stretch that extensive Holocene and Pleistocene alluvial surfaces are mapped (McGowen et al. 1972). Several tributaries of the West Fork flow southeast across Wise County (Big Sandy Creek and Denton Creek) and northeast across Johnson and Tarrant Counties (Clear Fork and Village Creek). Holocene floodplains averaging $1 \mathrm{~km}$ wide are mapped along these tributaries, as well as remnants of Pleistocene terraces (McGowen et al. 1967, 1972).

Branches of the Brazos River head west and northwest of the study area. Its tributaries, the Double Mountain Fork and Salt Fork, flow across the northern portion of the Abilene District, converging in Stonewall County. From here the Salt Fork flows northeast and exits the Abilene District. Another major branch, the Clear Fork, begins in the central part of the
Abilene District and flows east and northeast merging with the Salt Fork just north of the Brownwood District to form the Brazos River. From this point, the Brazos River flows southeast, reentering the study area in Palo Pinto County of the Fort Worth District. It continues to flow southeast across Parker, Hood, and Somervell Counties of the Fort Worth District. It enters the Waco District flowing southeast across Bosque, Hill, McLennan, and Fall Counties, and it continues on this course across Robertson, Milam, Brazos, Burleson, Grimes, and Washington Counties of the Bryan District. Exiting the Bryan District, the Brazos River continues southeasterly, flowing along the eastern edge of the Yoakum District (at Austin County), at which point it exits the study area.

From the city of Waco upstream to the confluence of the Clear Fork and Salt Fork of the Brazos, the Holocene floodplain of the Brazos River is very narrow (if not absent), and at Lake Whitney and Possum Kingdom Lake, it is below the surfaces of the flood pools (L. Brown et al. 1972; Hentz and Brown 1987; McGowen et al. 1972; Proctor et al. 1970). Pleistocene terraces are extensive along this stretch of the Brazos. Downstream from Waco, the Brazos River enters the Gulf Coastal Plain, and the Holocene floodplain is ca. 6-7 km wide and bordered by segmented Pleistocene terraces (Proctor et al. 1970). Dissected remnants of higher gravelly Pleistocene terraces are also sporadically placed along the upper slopes of the Brazos River valley. Traversing the Bryan District and the eastern edge of the Yoakum District, the floodplain of the Brazos varies from 2 to $12 \mathrm{~km}$ in width (Proctor et al. 1979; Proctor et al. 1981). Large segmented late Pleistocene terraces border the Holocene floodplain along this stretch of its course.

Several large tributaries of the Brazos traverse the seven-district area. In the Abilene District, large tributaries with mapped Holocene alluvium consist of the Clear Fork and Salt Fork. The Clear Fork has floodplain that is less than 1 to $2.5 \mathrm{~km}$ wide and is rarely flanked by Pleistocene terrace segments (L. Brown et al. 1972; Eifler et al. 1974; Hentz and Brown 1987). Tributaries of the Clear Fork with mapped Holocene alluvium traversing the Abilene and Brownwood Districts include Buffalo Draw and Alkali, Bitter, California, Cedar, Cottonwood, Deadman, 
Elm, Foyle, Gonzales, Hubbard, Lytle, Mulberry, Noodle, Plum, and Sweetwater Creeks.

The Salt Fork has a floodplain that is less than 1 to $2 \mathrm{~km}$ wide. Segmented Pleistocene terraces are present along the Salt Fork but are not common (Eifler et al. 1967). Tributaries of the Salt Fork with mapped Holocene alluvium traversing the Abilene District include the White River, Croton Creek, Double Mountain Fork, Duck Creek, and North Croton Creek.

From the confluence of the Salt and Clear Forks of the Brazos downstream to the City of Waco, several Brazos River tributaries within the Brownwood, Fort Worth, and Waco Districts display mapped Holocene alluvium. These tributaries include the Nolan and Paluxy Rivers and Aquilla, Big Caddo, Big Cedar, Childress, Dry, Keechi, Kickapoo, and Palo Pinto Creeks (L. Brown et al. 1972; McGowen et al. 1972; Proctor et al. 1970). Floodplains of these drainages measure less than $1 \mathrm{~km}$ to just more than $1 \mathrm{~km}$ in width. The larger streams such the Nolan and Paluxy Rivers and Palo Pinto, Aquilla, and Childress Creeks display small remnants of Pleistocene terraces.

At Waco and downstream to Austin County in the Yoakum District, several other large tributaries enter the Brazos River. They include the North Bosque, Little, Lampasas, Leon, and Navasota Rivers and Yegua Creek.

The North Bosque River heads in Erath County in the Fort Worth District and enters the Waco District in Hamilton County, flowing southeast and east through Hamilton, Bosque, and McLennan Counties before entering the Brazos valley. Its Holocene floodplain is ca. $1 \mathrm{~km}$ wide and bordered by a few small Pleistocene terrace segments or the bedrock valley wall (L. Brown et al. 1972; Proctor et al. 1970). Tributaries of the North Bosque River with mapped Holocene alluvium include the South Bosque, East Bosque, and Middle Bosque Rivers and Green, Duffau, Meridian, Neils, and Hog Creeks (L. Brown et al. 1972; Proctor et al. 1970).

The Little River is formed from the confluence of the Leon and Lampasas Rivers and flows southeast across Bell County of the Waco District and Milam County of the Bryan District. In central Milam County, its course changes to a northeasterly direction before turning again to flow in an easterly direction to meet the Brazos River at the Milam-Robertson County line. The Holocene floodplain of the
Little River is ca. $3 \mathrm{~km}$ wide and bordered by large segmented Pleistocene terraces along most of its course (Proctor et al. 1981). Near its confluence with the Brazos, the Little River's floodplain is $5-6 \mathrm{~km}$ wide. Tributaries of the Little River flow east, northeast, and southeast across the northern part of the Austin District, western part of the Bryan District, and southern part of the Waco District (Proctor et al. 1981). The largest tributary, the San Gabriel River, has a Holocene floodplain up to ca. $0.2 \mathrm{~km}$ wide that is flanked by segmented Pleistocene terraces. Other tributaries with mapped alluvium include Knob, Darrs, Donahoe, Big Elm, Pin Oak, and Sandy Creeks (Proctor et al. 1981).

The Leon River heads in Eastland County of the Brownwood District and flows southeast across Comanche County to enter the Waco District at Hamilton County. It continues southeast across Coryell and Bell Counties (Kier et al. 1976; Proctor et al. 1970). It merges with the Lampasas River in Bell County to form the Little River. The Holocene floodplain of the Leon is ca. $1 \mathrm{~km}$ wide and bound by Pleistocene terrace segments or the bedrock valley wall. Tributaries of the Leon River with mapped alluvium in the Brownwood and Fort Worth Districts include the Sabana River and Armstrong, Copperas, Holmsley, Indian, Resley, South Leon, and Warren Creeks. (Kier et al. 1976; L. Brown et al. 1972). Tributaries with mapped alluvium in the Waco District include Coryell, Cowhouse, Henson, Owl, and Plum Creeks (Proctor et al. 1970).

The Lampasas River begins in Mills County of the Brownwood District and Hamilton County of the Waco District and flows southeast through both districts. It then flows east and northeast across Bell County, where it merges with the Leon River to form the Little River. The Lampasas River has a relatively narrow Holocene floodplain averaging less than $1 \mathrm{~km}$ wide (Kier et al. 1976; Proctor et al. 1981). Small Pleistocene terrace remnants flank the floodplain along some segments of the river. Tributaries of the Lampasas River with mapped alluvium in the Brownwood District include Bennett, Lucy, Mesquite, School, Simms, and Sulphur Creeks (Kier et al. 1976). Tributaries with mapped alluvium within the Austin and Waco Districts include Rocky and Salado Creeks (Proctor et al. 1981).

The Navasota River begins in and flows 
southeast across Hill and Limestone Counties of the Waco District. It enters the Bryan District and flows south across Brazos, Grimes, Leon, Madison, and Robertson Counties. Near the city of Navasota in Grimes County, it meets the Brazos River. Along its upper course, the Navasota's Holocene floodplain is ca. $1 \mathrm{~km}$ wide; it widens to ca. $3 \mathrm{~km}$ along its lower stretch through the Bryan District (Proctor et al. 1970, 1981). Small remnant Pleistocene terraces flank the floodplain in the Waco District, becoming larger and more common along the river's lower course in the Bryan District. Larger tributaries of the Navasota River with mapped Holocene alluvium in the Waco District include Big, Blummers, Christmas, Faulkenberry, Sanders, and Steele Creeks (Proctor et al. 1970). Tributaries with mapped alluvium in the Bryan District include Brushy, Carters, Cedar, Duck, Gibbons, Holland, Rocky, West Caney, and Wickson Creeks (Proctor et al. 1970, 1981).

Yegua Creek begins in Williamson and Lee Counties of the Austin District and Burleson County in the Bryan District, where Middle Yegua and East Yegua Creeks converge. Yegua Creek flows eastward through Brazos, Burleson, Lee, and Washington Counties, meeting the Old River channel within the Brazos valley ca. $23 \mathrm{~km}$ downstream from Lake Somerville. The Yegua Creek floodplain is ca. $3 \mathrm{~km}$ wide, and Pleistocene terraces border it intermittently (Proctor et al. 1981). Holocene alluvium is also mapped for many of Yegua Creek's tributaries, including Alligator, Davidson, East Yegua, Middle Yegua, and Nails Creeks.

Several smaller tributaries with mapped Holocene alluvium enter the lower course of the Brazos River from the city of Waco to Austin County. In the Waco District, they include Tehuacana Creek, Cow Bayou, Deer Creek, Big Creek, and the Little Brazos River (Proctor et al. 1970). In the Bryan and Yoakum Districts, they include Caney, Cedar, Jackson, Mill, Mud, New Year, Pond, Rocky, and Walnut Creeks (Proctor et al. 1970, 1981).

Headwater tributaries of the Colorado River begin west and northwest of the seven-district area, coming together in Borden County of the Abilene District. It flows east and then southeast across Borden, Scurry, and Mitchell Counties of the Abilene District before it exits the study area. The Colorado River reenters the seven-district area in Coleman County of the
Brownwood District, flowing eastward and then southeastward across the district. It enters the Austin District in Burnet County, flowing south and then turning east and southeast across the district. It continues on its southeasterly course as it enters the Yoakum District in Fayette County. The Colorado River flows southeast across the Yoakum District to Matagorda Bay and the Gulf of Mexico.

In the headwaters area of Borden County, the Colorado River Holocene floodplain is 1.0 to $1.5 \mathrm{~km}$ wide, lacking higher Pleistocene terraces (Eifler et al. 1974). To the southeast in Mitchell County (Abilene District), the Holocene floodplain narrows, and large segmented Pleistocene terraces border the Colorado. Tributaries of the Colorado River along this stretch with mapped Holocene alluvium include Beals Branch, Big Silver, Bull, Gold, Grape, Kate, Red Bank, Rose, Wildcat, Wildhorse, and Willow Creeks.

The Holocene floodplain of the Colorado River is less than $1 \mathrm{~km}$ wide as it reenters the seven-district area in Coleman County of the Brownwood District and flows across the Brownwood and Austin Districts down to the city of Austin (Barnes and Rose 1981; Kier et al. 1976; Proctor et al. 1981). Along some portions of this stretch, it is not even mapped, or it lies under the conservation pools of the highland lakes. Pleistocene terraces are mapped along the western portions of this stretch of the Colorado but are nearly absent as the river flows through the narrow valleys and canyons of the Llano Uplift and Balcones Canyonlands. This portion of the Colorado River, from Coleman County to the city of Austin, has many tributaries with mapped Holocene alluvium. Within the Brownwood District, these include Antelope, Bluff, Bull, Cherokee, Clear, Corn, Cow, Deep, Elliot, Elm, Home, Nabors, Panther, Saddle, and Salt Creeks (Kier et al. 1976). In the Austin District, tributaries with the mapped alluvium include Alligator, Hamilton, Little Cypress, and Sandy Creeks and Whitman Branch (Barnes and Rose 1981).

Three larger tributaries-Pecan Bayou and the Llano and Pedernales Rivers-also merge with the Colorado River along this segment of its course. Pecan Bayou begins in Callahan County of the Abilene District and flows southeast across the Abilene and Brownwood Districts to meet the Colorado River in Mills County. The Pecan Bayou floodplain ranges from less than 
$1 \mathrm{~km}$ to almost $3 \mathrm{~km}$ wide (L. Brown et al. 1972; Kier et al. 1976). Pleistocene terrace segments flank portions of the floodplain but are rare. In the Abilene District, tributaries to Pecan Bayou displaying mapped Holocene alluvium include Clear Fork Pecan Bayou, Middle Fork Pecan Bayou, and Crooked Creek (L. Brown et al. 1972). In the Brownwood District, tributaries displaying mapped Holocene alluvium include Red River and Blanket, Brown, Doudle, Greenbriar, Hog, Jim Ned, Little Pecan, Mullin, Pompey, Salt, Steppe, and Willis Creeks (L. Brown et al. 1972; Kier et al. 1976).

The Llano River forms from the merger of the South Llano and North Llano Rivers at Junction, just west of the Austin District. As it enters the district, it flows east across Mason and Llano Counties and then turns southeast to join the Colorado River at Kingsland. The Holocene floodplain and older Pleistocene terraces along this stretch of the Llano River are not extensive (or are altogether absent) and are rarely mapped (Barnes and Rose 1981). Few tributaries of the Llano River within the Austin District have mapped Holocene alluvial deposits; these include the Little Llano River and the James River.

The Pedernales River heads in the western portion of the Austin District (Gillespie County) and flows east. It becomes deeply entrenched and canyon-confined as it traverses the Lower Cretaceous rocks near the eastern margin of the Edwards Plateau. Here, it turns and flows northeast to the Colorado River upstream from Austin. A narrow Holocene floodplain (less than $0.1 \mathrm{~km}$ ) is mapped for the western stretch of the Pedernales, and floodplains are rare as it enters the canyons of the eastern Edwards Plateau (Barnes and Rose 1981). Small Pleistocene terraces are mapped within the canyon-confined portion of the river. Tributaries of the Pedernales River with mapped Holocene alluvium include Dittmar Creek, Palo Alto Creek, South Grape Creek, White Oak Creek, and Williamson Creek.

The Colorado River enters the Gulf Coastal Plain near the city of Austin, where its valley and floodplain widen considerably. From this point and downstream across the Gulf Coastal Plain, the Holocene floodplain varies from 1 to $10 \mathrm{~km}$ wide and is bordered by extensive Pleistocene terraces (T. E. Brown et al. 1975; Proctor et al. 1974, 1981). Near the city of La Grange, upstream from Columbus, and down- stream from Wharton, the floodplain narrows as the channel wedges between Pleistocene terraces and bedrock valley walls (Proctor et al. 1974). Tributaries along the Colorado in the Austin District that display mapped Holocene alluvium include Barton, Cedar, Gilleland, Little Pin Oak, Onion, Walnut, and Wilbarger Creeks (Proctor et al. 1974, 1981). In the Yoakum District, tributaries with mapped Holocene alluvium include Blue, Buckners, Cummins, Rabbs, Skull, and Williams Creeks (Proctor et al. 1974).

The Guadalupe River heads south of the Austin District and west of the Yoakum District. It enters the seven-district area in Gonzales County and flows east and then southeast across the Yoakum District before it empties into San Antonio Bay. Throughout the Yoakum District, the upper portion of the Guadalupe River floodplain is less than 0.5 to $4.5 \mathrm{~km}$ wide and sporadically flanked by large Pleistocene terraces (Proctor et al. 1974). Along its lower course, the floodplain is 1 to $7.5 \mathrm{~km}$ wide and intermittently bordered by Pleistocene terraces and terraces of the Deweyville Formation (T. E. Brown et al. 1975). Tributaries of the Guadalupe River within the Yoakum District displaying mapped alluvium include Coleto, McCoy, Peach, and Sandies Creek (T. E. Brown et al. 1975; Proctor et al. 1974). Two larger tributaries to the Guadalupe River, the San Marcos and San Antonio Rivers, and many of their tributaries display wide Holocene floodplains that Pleistocene terraces flank intermittently.

The San Marcos River begins in Blanco County of the Austin District and flows southeast into the Yoakum District to meet the Guadalupe River in Gonzales County. The San Marcos floodplain varies from less than 1 to $2 \mathrm{~km}$ in width and is flanked by segmented Pleistocene terraces (Proctor et al. 1974). Tributaries of the San Marcos River with mapped Holocene alluvium include Brushy, Plum, and York Creeks.

Only a short segment of the San Antonio River traverses the seven-district area before it joins the Guadalupe River just northwest of San Antonio Bay. The San Antonio River heads west of the Yoakum District and flows southeast, entering the Yoakum District in Victoria County. Within the boundaries of the Yoakum District, the floodplain of the San Antonio River is up to $5 \mathrm{~km}$ wide and is bordered by Pleistocene terraces (T. E. Brown et al. 1975). 


\section{SYNOPSIS OF NATIVE AMERICAN CULTURE HISTORY}

\section{2}

The following culture history summaries divide the study region into six areas based on an amalgam of environmental and cultural characteristics (Figure 3). Some of these areas are more coherent as cultural regions, but others with less well-defined culture histories are based more on natural environments. Other differences between the sections arise from the fact that the archeology of some of these areas has been synthesized to a substantial extent in recent publications, but this is not the case in other areas. Hence, some summaries deal with the broad sweep of cultural developments, and others focus on serially recounting what has been learned from investigations at particular sites within a given area. No summary coincides precisely with a TxDOT district, and in most cases it has been necessary to use archeological information from multiple districts, including some outside the current study area, to construct summaries that make sense.

\section{Central Coastal Plain}

\section{Previous Research}

Many people, institutions, and governmental agencies have undertaken archeological investigations on the central coastal plain of Texas. Among the more prominent of these are excavations by The University of Texas at Austin and the Works Progress Administration at the Johnson and Kent-Crane sites in the Copano Bay and Aransas Bay areas (Campbell 1947, 1952); Story's (1968) excavations at the Ingleside Cove and Anaqua sites in San Patricio and Jackson Counties; excavations at 41AU37 and 41AU38 along Allen's Creek in southern Austin County by The University of Texas at Austin
(Hall 1981); excavations by the University of Texas at San Antonio (UTSA) at the Hinojosa site situated approximately $60 \mathrm{~km}$ inland from Corpus Christi Bay (Black 1986); explorations by the Texas Historical Commission in the projected area of Palmetto Bend Reservoir along the Lavaca and Navidad Rivers of Jackson County (Mallouf et al. 1973); UTSA survey and site testing in the area of Coleto Creek Reservoir in Victoria and Goliad Counties (Fox and Hester 1976; Fox et al. 1979); extensive survey and excavation efforts, primarily by UTSA, at Choke Canyon Reservoir in Live Oak and McMullen Counties (K. Brown et al. 1982; Hall et al. 1982, 1986; Highley 1986); excavations by the Texas Department of Transportation (TxDOT) at the Loma Sandia site in Live Oak County and subsequent analysis by The University of Texas at Austin (Taylor and Highley 1995); TxDOT-sponsored excavations by UTSA at Mission Nuestra Señora del Refugio in Refugio County (Meadows et al. 2002; Tennis 2002); Robert A. Ricklis's (1988, 1989, 1995, 1996) work at the Holmes and McKinzie sites, among others, in the Corpus Christi and Copano Bay area; testing and data recovery excavations at sites along the Victoria Barge Canal in Victoria and Calhoun Counties, much of which has not yet been published (Gadus et al. 1999; Weinstein 1992); and recent work by the Texas Historical Commission at La Salle's Fort St. Louis and the first location of Presidio La Bahía (Bruseth and Durst 2002; Davis and Bruseth 2000, 2001; Davis et al. 2000), as well as work at other Spanish Colonial Missionperiod sites (Calhoun 1999; Hindes et al. 1999; Ricklis 1999; Walter 1999). Summaries of the prehistory of the region based on these investigations, and more complete bibliographies 


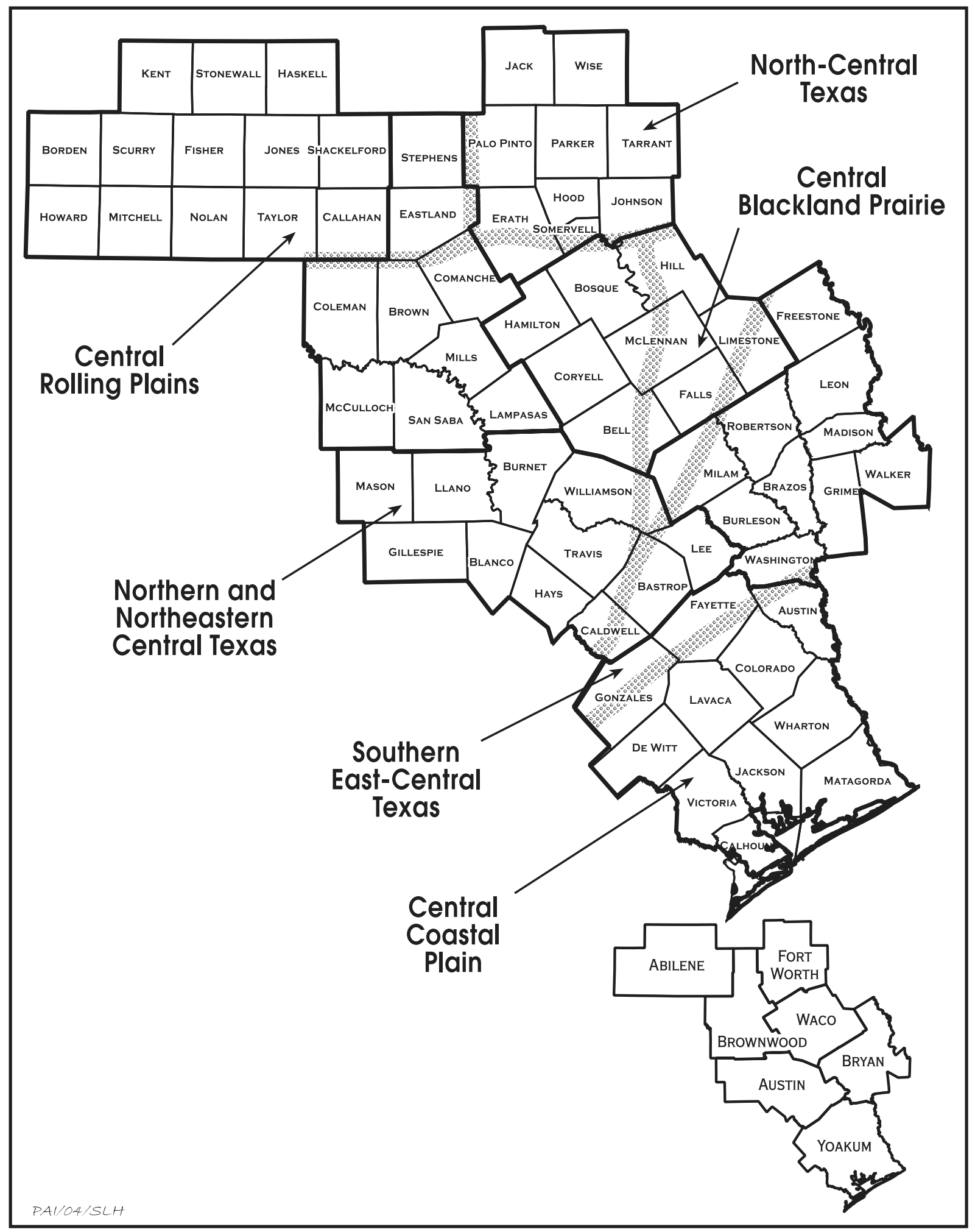

Figure 3. Map showing the six culture history summary areas. 
concerning previous work, have been compiled by Black (1989a), Weinstein (1992), Hester (1995), Ricklis (1995), and Tomka et al. (1997).

\section{Paleoindian Period}

The earliest occupation of the coastal plain occurred in the Paleoindian period ca. 11,000 to 8,000 years ago. The first half of this period is marked by the occurrence of Clovis and Folsom dart points, almost always in isolated contexts. For instance, a Clovis point was recovered from San Patricio County near the mouth of the Nueces River (Hester 1976), and a Folsom point was recovered on Oso Creek (Hester 1980:6). Excavated Paleoindian components on the coastal plain include the deep terrace sites of Buckner Ranch in Bee County, the Berger Bluff site in Goliad County, and the Johnston-Heller and J-2 Ranch sites in Victoria County. The Buckner Ranch site produced late Pleistocene fauna and hearth-like clusters of burned rocks, as well as Folsom, Plainview, Scottsbluff, and Angostura points (Sellards 1940). Hester (1976:8-9), in a reevaluation of Sellards's data, concluded that the site "served as a campsite for a succession of Paleo-Indian groups" possibly spanning 3,000 years. Though this site is the only one of the excavated components to produce a Folsom point, in a more recent discussion Hester (1995:434) states "no Folsom camps or kill sites have been located."

Late Paleoindian points such as Plainview and Golondrina have been recovered from the Johnston-Heller site and the J-2 Ranch site (Birmingham and Hester 1976; Fox et al. 1979). Clear Fork tools also were recovered at the Johnston-Heller site. The Berger Bluff site, now inundated by Coleto Creek Reservoir, produced a deeply buried hearth dated to ca. 8,000 to 6,000 years ago. This site is of interest because its faunal assemblage includes small animals not thought to be characteristic of a Paleoindian biggame subsistence pattern (Brown 1996:497-498; Weinstein 1992:60). Investigation of these components indicates the earliest Americans' longlived, slowly changing adaptation to the near-coast.

Evidence of Paleoindian use of the coastal zone also comes from isolated finds in eroded or disturbed contexts. The erosion is in part the result of a dramatic sea-level change associated with the end of the last glaciation. At that time, sea level was much lower than today, and the Gulf shoreline was appreciably farther south of its present position (Aten 1983:117, 146). As sea level began to rise, it likely inundated many Paleoindian sites. Both artifacts and fossil bones have been recovered from Texas beaches and are believed to be eroding from submerged, relict deltaic landforms that contain these ancient sites. One such area that has produced artifacts and fossil bones is 41MG4, the Sargent Beach site. The site produced one late Paleoindian Angostura point, as well as Archaic Pedernales and Kent points and fossil bones, including horse, bison, and mammoth teeth. Fossil bones and teeth of mastodon, mammoth, bison, horse, camel, deer, and turtle without associated artifacts have been recovered from several nearby disposal areas for dredged materials along the Gulf Intracoastal Waterway west of the San Bernard River (Black and Cox 1983) and to the south in alluvium of the ancestral Palo Blanco River of northern Kenedy County (Shum 1980).

\section{Archaic Period}

Toward the end of the Paleoindian period, a disruption in large game populations may have precipitated a greater reliance on a broad-based subsistence strategy (Aten 1983:152-157). This presumed but probably overstated change in subsistence strategy has been used to mark the beginning of the Archaic period. There also is evidence of climatic fluctuations and additional episodes of sea level rise within this period. These fluctuations have been used to divide the Archaic into early, middle, and late subperiods.

The Early Archaic spans the period from 8000 to 5000 B.P. when sea level was still well south of its present location (Aten 1983:117). As with Paleoindian sites, few Early Archaic sites are known, and it has been suggested that populations and site densities continued to be low on the entire coastal plain (Story 1985a:37). Projectile points diagnostic of the period include Andice, Bell, Gower, Martindale, Uvalde, Wells, and related forms (Black 1989a:49; Weinstein 1992:57). Inland along the edge of the coastal plain, sites are associated with upland landforms and high terraces, though several components within deep alluvium are known from the Choke Canyon area of Live Oak County (Scott and Fox 1982). Examples of sites from the coastal bend include 41VT17 (Fox and Hester 
1976), the McKenzie site (Ricklis 1988), and the Swan Lake site (Prewitt et al. 1987). Though the Early Archaic components at these sites are ephemeral, they demonstrate early use of the estuarine bay shore environment. During the late part of the Early Archaic, the number of coastal components increased, as did the intensity of the occupations. It appears that both shellfish and fish were exploited to the extent that these early components likely functioned as fishing camps (Ricklis 1988:101-102, 1995: 272-278).

The coastline reached its present position in the Middle Archaic, which lasted from 5000 to 3000 B.P., with the climate approaching modern conditions at the end of the period (Aten 1983:137, 316; Story 1990:244). It has been suggested that these changes may have enhanced coastal resources enough that populations and site densities increased (Story 1985a:39, 1990:244). Toward the end of this period, extensive shell middens appeared, signaling that the bays and estuaries had developed to the extent that shellfish had become a ubiquitous resource. On the coast in Aransas and Nueces Counties, this intensive exploitation of estuarine resources has been given the appellation Aransas focus or complex (Campbell 1947, 1952), with the Middle Archaic manifestation labeled the Ken phase (Weinstein 1992:61). Distinctive shell tools such as Busycon whorl scrapers and columella gouges mark Aransas sites. Similar tools have been recovered from shell midden sites as far north along the coast as Lavaca Bay and the lower reach of Caney Creek in Matagorda County (Fritz 1975:129). Projectile points including Bulverde, Matamoros, and Palmillas mark this phase. Other Middle Archaic period projectile points with inland ties include Morhiss, Nolan, Refugio, and Travis (Black 1989a:49; Weinstein 1992:61).

In the inland southern part of the region, data from the Choke Canyon Reservoir sites suggest that open camps along stream courses on natural levees and low terraces marked the Middle Archaic period. Features such as formal hearths, earth ovens, and concentrations of burned rocks point to an emphasis on the use of plant resources (Hall et al. 1986). Possible baking pit features with associated concentrations of burned rocks also have been identified at coastal shell midden sites. One such Middle Archaic shell midden-41CL9 situated in
Calhoun County along the upper Guadalupe River estuary-also produced faunal data indicating that terrestrial resources contributed significantly to the coastal resource base (Gadus et al. 1999:35-73).

The Late Archaic period, which dates from ca. 3000 to 1250 B.P., is marked by a continuation and intensification of Aransas adaptations on the coast as represented at sites such as KentCrane (Campbell 1958; Corbin 1974). Some sites, such as Mustang Lake on San Antonio Bay and Ingleside Cove on Corpus Christi Bay, produce faunal data that suggest intensive fishing (Ricklis 1995:281-280). Inland, the presence of grinding implements and large deposits of burned rocks at the Choke Canyon sites suggest continued, intensive exploitation of plant resources (Hester 1995:441). Point types found on the coast include Ensor, Darl, and Fairland. Inland point types for this period include Frio, Marcos, Montell, Morhiss, Castroville, and Ellis (Black 1989a:51; Weinstein 1992:57). Overall, this period saw a continued increase in populations and trend toward defined territories (Story 1985a:44-45, 48).

One indication of population increase is the expansion of formal cemeteries. Cemeteries appeared in the Middle Archaic period and grew in size and number through the Late Archaic and into the Late Prehistoric period (Hall 1995a:56-57). An extensive Middle Archaic through Late Prehistoric period cemetery has been excavated at Allen's Creek (Hall 1981). The site, 41AU36, is on the Brazos River approximately $115 \mathrm{~km}$ north of the coast in Austin County. Burials showed an increase in traumatic deaths, specifically during the Late Archaic period, that might be considered evidence of a boost in hostilities suggesting greater territorial competition (Hall 1981:284-285). Closer to the coast, the Blue Bayou cemetery (41VT94) and the Morhiss cemetery (41VT1) are situated on the lower reach of the Guadalupe River in Victoria County (Campbell 1976:81-85; Huebner 1988). The Morhiss cemetery has been dated to the Archaic period by diagnostic projectile points recovered from the associated habitation site. Because shell ornaments and many lithic materials were recovered from the habitation site, investigators have suggested that the inhabitants had both inland and coastal interactions (Hall 1995a:49-50). Similar interactions can be suggested from the inland formal cem- 
etery at the Loma Sandia site in Live Oak County (Taylor and Highley 1995). But Hall (1995b:645-646) points out that, though the grave furnishings from Loma Sandia suggest interaction with nearby coastal cultures, the overriding connection appears to be with cultures of the Rio Grande Plain. These suggested differences in interaction provide data needed for understanding territorial affiliations across the coastal plain.

\section{Late Prehistoric Period}

The Late Prehistoric period began variously along the Texas coastal plain at ca. 1700 to 1250 B.P. It was marked by the addition of pottery and the bow and arrow to an otherwise Archaic technological repertoire (Aten 1983:297-304; Corbin 1976:91; Weinstein 1992:57). Scallorn arrow points, one of the earliest forms found on the coast, have been recovered from burials at the Blue Bayou site dating to the early Late Prehistoric, ca. A.D. 430-990 (Huebner 1988). Scallorn points and expandingstem arrow point forms also were recovered from more-inland sites such as the Berger Bluff site in Goliad County (Brown 1983) and sites in the Choke Canyon area of Live Oak County (Hall et al. 1986). In many cases, no ceramics were associated with these components, suggesting separate arrival or development of the two technologies. Similarities of these components to the early Late Prehistoric Austin phase components of central Texas have been acknowledged (Brown 1983: 80-81; Weinstein 1992:63).

Slightly later but before A.D. 1000, bonetempered ceramics and expanding-stem arrow points are known from the Choke Canyon sites (Black 1989a:52), and Scallorn points and sandy paste ceramics like ceramics from the upper Texas coast appeared on the central coast. Scallorn points and sandy paste ceramics were recovered from the Anaqua site and other sites situated along the lower Lavaca and Navidad Rivers in Jackson County (Mallouf et al. 1973:136; Story 1968), as well as the Kent-Crane site in Aransas County (Cox and Smith 1988). Weinstein (1992:64) suggests that these components are recognizable cultural manifestations that preceded introduction of Rockport ceramics along the south and central coasts.

Rockport ceramics, a sandy paste ware decorated with asphalt designs and incising, occur most often with Perdiz and Fresno points. Other arrow point types occasionally found include Cliffton, McGloin, Padre, Scallorn, Starr, and Young (Corbin 1974:43). The occurrence of these artifact types along the coast-generally in Aransas, Kleberg, Nueces, Refugio, and San Patricio Counties-has been used to define the Rockport phase of the Late Prehistoric-Historic period (Campbell 1952, 1958; Story 1968; Suhm et al. 1954). The Rockport phase has been linked to the historically known Karankawa Indians because that group continued to produce the distinctive asphalt-decorated and asphaltcoated ceramics well into historic times.

Archeological studies of prehistoric and historic Karankawa adaptive strategies suggest that these people took advantage of both coastal estuarine and adjoining prairie-riverine resources. Based on sites in the Corpus Christi Bay and Copano Bay area, Ricklis (1996:100124) discerned a seasonal pattern in the occupation of coastal and nearby inland sites that may reflect this strategy. Two Late Prehistoric site types have been identified. One is a shoreline fishing camp that has extensive deposits of estuarine resource remains, and the other is an inland hunting camp with large quantities of terrestrial game such as deer and bison (Ricklis 1996:33). Seasonal data based on fish otoliths and Rangia cuneata samples indicate that the fishing camps were occupied in the fall through winter or early spring and that hunting camps were occupied in the spring and summer (Ricklis 1996:70-71, 89-95). In this model, fishing camps were occupied at a time of year when a reliable resource-that is, fish-was concentrated along the coast and allowed people to mass. Concomitantly, hunting camps represent population dispersal geared toward more-scattered resources-bison and deer. How far inland the Karankawa may have journeyed on their seasonal round and what interactions they may have had with inland-based groups are questions that require additional research.

Though the Karankawa may have moved inland seasonally to hunt bison and deer, faunal evidence from Hinojosa site in Jim Wells County and the Choke Canyon sites suggests that resident inland groups may have focused both on large game and a wide range of smaller animals (Steele 1986; Steele and Hunter 1986). Recognition of a related lithic tool kit emphasized the importance of large game such as 
bison to the subsistence base (Black 1989a:5354). Consisting of Perdiz arrow points, small end scrapers, and beveled knives, this tool kit has been linked to the Toyah phase cultures that appear to have originated on the Southern Plains and moved south to central Texas, probably in response to southward-expanding bison herds (Black 1989a:57). The Toyah phase tool kit has been identified at the Hinojosa site and is often found within Rockport phase sites on the central coast (Black 1986:254-255; Ricklis 1995:285, 287). But the mechanisms behind adoption of this Toyah technology and its meaning for the coastal and near-coastal peoples have yet to be clearly defined (see Johnson [1994] for a wide-ranging discussion of the Toyah culture).

\section{Historic Period}

Coastal aboriginal groups were affected not only by inland aboriginal groups, but they also bore the brunt of early contact with European explorers and colonists. The first encounter was that of the Spanish shipwreck survivor and eventual trader Alvar Nuñez Cabeza de Vaca, who lived and traveled with various aboriginal groups across coastal Texas ca. 1528 (Hester 1999:17-19). Reestablishing Cabeza de Vaca's movements places him on the Texas coast in the vicinity of San Antonio, Copano, and Corpus Christi Bays (Campbell and Campbell 1981:29). The Karankawa also met Robert Sieur de La Salle on his fateful expedition that ended along Matagorda Bay in the winter of 1685 (Ricklis 1996:1, 112). Recent work at the site of La Salle's Fort St. Louis (41VT4) and the excavation of La Salle's ship, the Belle, in Matagorda Bay will provide new information on this contact and the lives of the Frenchmen who participated in that expedition (Bruseth and Durst 2002; Davis and Bruseth 2000; Davis et al. 2000). The French presence on the Texas coast was short, but the Spanish, with their emphasis on establishing missions and presidios, had a lasting effect.

Spanish attempts to establish missions and presidios along the coastal plain continued through the 1700s. These included Mission EspírituSanto, established in 1722 in the present vicinity of Jackson County and then moved to Victoria County in 1726, Presidio La Bahia and Mission Rosario established in 1749 and 1754 in Goliad County, and Mission
Nuestra Señora de Refugio, first situated in Calhoun County and then moved to Refugio County in 1795 (Ricklis 1996:145). Recent investigations of some of these sites, especially the work by TxDOT and UTSA at Mission Refugio and Ricklis's excavations at Missions Espíritu Santo and Nuestra Señora del Rosario, have provided important information on mobility patterns, diet, technologies, economic activities, acculturation, demographic patterns, health, and interactions between the Spanish and Native Americans (Calhoun 1999; Meadows et al. 2002; Ricklis 1999; Tennis 2002; Walter 1999). These investigations, as well as work on Late Prehistoric and historic aboriginal sites, appear to indicate that coastal aboriginal groups kept their ethnic identities despite attempts by the Spanish to missionize them, and to some extent they fit the mission system into their aboriginal subsistence pattern (Ricklis 1996:159-168). Consequently, local coastal Native American groups, such as the Karankawa, survived as much-reduced but viable groups into the nineteenth century. Native groups did not, however, survive the aggressive Anglo-American settlement of the Texas coast that took place during the nineteenth and twentieth centuries.

\section{Southern East-Central Texas}

\section{Previous Research}

This synopsis focuses on the southern part of east-central Texas-most of the Bryan District, the northern part of the Yoakum District, and the eastern edges of the Austin and Waco Districts. Most of this area is within the Oak Woodlands region, although Blackland Prairie occurs along the western and southern edges and in a narrow band through the middle. The archeology of parts of this area is reasonably well understood because several large-scale projects involving excavations have been undertaken. Among those projects that have contributed important information are Richland-Chambers Reservoir in Freestone and Navarro Counties (Bruseth and Martin 1987; McGregor and Bruseth 1987); Lake Limestone in Leon, Limestone, and Robertson Counties (Mallouf 1979); Jewett Mine in Freestone and Leon Counties (Day 1984; Fields 1987, 1990; Fields and Klement 1995; Fields et al. 1991; Gadus et al. 2002); Calvert Mine in Robertson 
County (Davis et al. 1987; Robinson and Turpin 1993); Sandow Mine in Lee and Milam Counties (Ricklis 2001; Rogers 1997, 1999; Rogers and Kotter 1995); Gibbons Creek Mine in Grimes County (Rogers 1993, 1994, 1995); Somerville Lake in Burleson, Lee, and Washington Counties (Peterson 1965; Thoms and Ahr 1996); Cummins Creek Mine in Fayette County (Kotter et al. 1991); Fayette Power Plant in Fayette County (Skelton 1977); 41BU16 and 41BU51 in Burleson County, 41MM340 and 41MM341 in Milam County, the Kennedy Bluffs and Bull Pen sites in Bastrop County, and the Black Hopper site in Fayette County excavated because of Texas Department of Transportation projects (Bement et al. 1989; Ensor and Mueller-Wille 1988; Fields et al. 2004; Fullem 1977; Gadus et al. 2003; Mahoney et al. 2003; Roemer and Carlson 1987); and miscellaneous excavations such as those at the Winnie's Mound and Frisch Auf! sites (Bowman 1985; Hester and Collins 1969).

Not surprisingly given its location, the archeology of this region often has been seen as reflecting influences from adjoining regions with better-defined cultural histories, with the strength of these influences varying across the area. For example, Caddoan influences predominate in the northern part of the study area, coastal influences are especially strong on the southeastern edge, and similarities to central Texas are most pronounced on the southern and western margins.

\section{Paleoindian Period}

As elsewhere in Texas, excavated and reported Paleoindian materials from southern east-central Texas are scarce, but a variety of early points have been found, largely in mixed or surface contexts, and it is clear that this part of Texas was used throughout the period from ca. 10,000 to 6500 B.C. Presumably, this use was by hunter-gatherer groups with low population densities and high residential mobility. One significant early find, estimated to date between 12,000 and 10,000 B.P. was at the DuewellNewberry site in Brazos County (Carlson et al. 1984). The find consisted of mammoth remains deeply buried in Brazos River alluvium. Although no artifacts were found in association, some of the bones contained cut marks indicating human modification. Other early materials from the region include a few San Patrice points from Richland-Chambers Reservoir (McGregor and Bruseth 1987:176-179); one Folsom point from Lake Limestone (Mallouf 1979:44); a Golondrina point, several untyped lanceolate points, and a radiocarbon assay of 8940 B.P. from the Lambs Creek knoll site at the Jewett Mine (Fields 1995:304), as well as a Clovis point, a Meserve-Dalton point, and two San Patrice points from two other sites (Day 1984:83; Fields et al. 1991:317); a San Patrice point and a Plainview-like point from the lowermost stratum at the Winnie's Mound site (Bowman 1985:44); a Plainview point and a Golondrina point from the Chesser site and a Clovis point and possible Clovis blade in redeposited contexts at $41 \mathrm{LE} 177$ at the Sandow Mine (Ricklis 2001:150; Rogers and Kotter 1995:134); occasional Dalton and San Patrice points from sites at the Gibbons Creek Mine (Rogers 1995:166); a Dalton point from Somerville Lake (Thoms and Ahr 1996:13); and a few Plainview and Meserve points from sites in the Fayette Power Plant project area (Skelton 1977:124).

\section{Archaic Period}

Many of the excavated sites in the region have components dating to the Archaic period (ca. 8500-1250 B.P.), and it is clear that the area supported sizeable populations by the last third of the period. Materials dating to the early and middle parts of the period are widespread but not very abundant. For example, the relatively intensive work at Richland-Chambers Reservoir and Lake Limestone and Jewett Mine at the north end of the study area suggests limited use of the western edge of the Oak Woodlands before the Late Archaic, although for both areas it has been noted that data pertaining to the early to middle parts of the Archaic may be scarce in part because sites dating to this interval lie deeply buried or were removed by extensive erosion during the mid-Holocene (Fields 1995:302; McGregor and Bruseth 1987:229). Only a few radiocarbon assays predating 4000 B.P. were obtained from these project areas, and only one excavated site, Charles Cox at the Jewett Mine, contains a substantial component that might be Early or Middle Archaic in age (Fields 1995:303305). A variety of untyped dart points with expanding and parallel stems appear to represent this component, but later materials are mixed 
in as well, and the deposits were not dated by radiocarbon. Points dated to this interval in central Texas-for example, Bell, Andice, Calf Creek, and Hoxie-occur at both RichlandChambers Reservoir and the Jewett Mine, but only in very small numbers.

Similar conclusions can be reached for the other project areas listed above. The work at the Calvert Mine has not revealed evidence of significant Early to Middle Archaic occupations, and the evidence from most of the excavated sites at the Sandow Mine is limited as well-an early split-stem point, an Angostura-Hoxie point, and two Travis points from the Chesser site and a Martindale point from 41LE120 (Rogers 1997:52; Rogers and Kotter 1995:134). Site 41LE177 at the Sandow Mine contained an Early Archaic component represented by an Angostura point, an early split-stem point, a Uvalde point, two or three Hoxie points, and a hearth-debris cluster, as well as some perhaps redeposited Middle Archaic materials, including two Early Triangular points and a Travis point, but these components suffered from integrity and dating problems and were difficult to interpret other than noting that they probably reflected short-term occupations for hunting-related activities (Ricklis 2001:143, 145, 150).

Early to Middle Archaic materials elsewhere in the region, all from sites that date predominantly later, include a Hoxie point from 41GM166 at the Gibbons Creek Mine (Rogers 1995:166-167); an Angostura-like point from Somerville Lake (Thoms and Ahr 1996:13); a few Hoxie, Nolan, Travis, and Uvalde points from the Cummins Creek Mine (Kotter et al. 1991:111, 124, 136); single Gower and Angostura points from the Fayette Power Plant (Skelton 1977:124, 125); and a Travis point from the Black Hopper site (Fullem 1977:11).

Two excavated sites with substantial Early to Middle Archaic components are Winnie's Mound and Kennedy Bluffs, although the primary components at both of these sites are Late Archaic. At the former, a Bell point, a Hoxie point, five Gower-Uvalde-like points, two Gowerlike points, and five Hoxie-Gower-Uvalde-like points were found in the lower strata, along with at least one hearth (Bowman 1985:43-47, 70). At Kennedy Bluffs, only a few Early to Middle Archaic points (one Travis, one TortugasTaylor, two Angostura, one Gower-like, and one
Nolan) were found in the area TxDOT excavated, but many items dating to this interval were documented among the materials collectors recovered from another part of the site (Bement et al. 1989:35-36, 71-154). Given the limited information available for this part of the period, it is difficult to say much about adaptations and lifeways. It does appear, however, that the region was used in a limited fashion, presumably reflecting low population densities among mobile hunter-gatherers.

The late part of the Archaic period-after about 4000 B.P.- presents a very different picture. All parts of the area that have been studied archeologically contain sites dating to this period, and the Late Archaic represents the earliest time for which much is known about Native American lifeways. One of the morecomplete pictures of the archeology of the Late Archaic for this region comes from the Oak Woodlands on the north edge of the study area. Along Richland and Chambers Creeks, Late Archaic groups appear to have been huntergatherers whose subsistence pursuits focused on wild plant foods such as hickory nuts and prairie turnip and faunal taxa such as deer, turtles, small mammals, birds, and fish (McGregor and Bruseth 1987:236-240). Although presumably not sedentary, these groups clearly used the area intensively for residential purposes, and populations appear to have increased. A conspicuous component of the record is the so-called Wylie pit, examples of which were excavated at the Bird Point Island and Adams Ranch sites. These were large features that appear to have been used for communal processing of vegetal resources (and later as cemeteries), perhaps in the context of band aggregation in tension zones as territories decreased in size (McGregor and Bruseth 1987:237).

The Navasota River valley and the area eastward to and across the Trinity River divide also were occupied with increased intensity during the Late Archaic period (Fields 1995:307309), although there is no evidence for the kind of population aggregations indicated at Richland-Chambers Reservoir. Faunal and macrobotanical remains were not preserved in the Late Archaic components at Lake Limestone and the Jewett Mine, except for the ubiquitous hickory nut shells, and thus data on subsistence are limited. Nonetheless, it is surmised that 
these hunter-gatherers subsisted on a variety of wild plant foods and game, especially deer. Of the 20 excavated components assigned to this period, 15 are interpreted as residential bases and 5 as procurement or processing locations. Five of the residential-base components are situated along the Navasota River and appear to represent general-purpose campsites, and the others are in the uplands to the east and consist of 2 general-purpose residential bases and 8 residential bases at which activities focused heavily on plant processing and secondarily on hunting. This distinction suggests that Late Archaic settlement systems were based on the occurrence of plant foods. The analysis units interpreted as procurement-processing locations appear to have focused primarily on plant processing and then on hunting-related activities. Four of these are along streams in the uplands, and the fifth is along a Navasota River tributary to the west. The data from these 20 components are consistent with the idea that Late Archaic groups were chiefly foragers because procurement-processing locations suggesting logistical use are not frequent. Settlement systems appear to have been highly scheduled, probably by season, with residential sites in riverine settings differing from those in the uplands. Comparisons with earlier components at Lake Limestone and the Jewett Mine are difficult, but the much greater frequency of Late Archaic components and the overall greater intensity of use suggest increased population densities, decreased territories, or both. The occurrence of a Late Archaic cemetery at the Cottonwood Springs site along Lambs Creek on the east side of the Navasota River valley also points to this shift (Fields and Klement 1995).

Not only do constellations of projectile point styles (e.g., Dawson, Gary, Godley, Kent, Neches River, and Yarbrough) from the RichlandChambers, Lake Limestone, and Jewett Mine areas indicate ties to the north and east rather than to the south and west, but each of these areas also has yielded information suggesting that ceramics may have been introduced into the material culture of local groups during the latest part of the Late Archaic, as they were across most of Texas to the east (where this interval usually is called the Early Ceramic period and sometimes the Woodland period).

At Richland-Chambers Reservoir, distinctive shell-tempered sherds were recovered from contexts dated between A.D. 200 and 700 at the Adams Ranch site (McGregor and Bruseth 1987:180-181), apparently representing the earliest ceramic industry in this part of the Trinity River basin. At Lake Limestone and the Jewett Mine, a few shell-tempered sherds, a few sherds with a fine kaolin paste but no obvious temper, and larger numbers of sandy paste ceramics and grog- or bone-tempered ceramics were found in contexts that appeared to predate arrow points (i.e., the latter part of the Late Archaic). Although some of these could be genuinely early, especially the sandy paste wares that are so reminiscent of the early ceramics that predominate in east Texas south of the Sabine River, it is possible that the other sherds intruded from later deposits (Fields 1995:308). In either case, sherds were sufficiently infrequent to suggest that, although ceramic containers may have been a notable addition to the material culture, they were not abundant.

The Late Archaic archeology of the other project areas in southern east-central Texas has not been deciphered to the same extent as that at Richland-Chambers Reservoir and the Jewett Mine, but it is clear that similar, though not identical, cultural developments occurred within hunter-gatherer groups across the region. The single excavated site at the Calvert Mine, 41RT267, apparently contains a Late Archaic component, but small sample sizes and the lack of features hamper interpretation (Robinson and Turpin 1993). Two of the excavated sites at the Sandow Mine-the Chesser site and the Walleye Creek site-have strong Late Archaic components. At these sites, many burned rock features were found in association with dart point types such as Bulverde, Darl, Ensor, Fairland, Lange, Marcos, Marshall, and Pedernales (Rogers 1999:96; Rogers and Kotter 1995:134). Although these types show distinct ties to central Texas in general, Rogers (1999:96-97) argues that the last three represent more-local types especially common to the eastern margin of the Edwards Plateau. Site 41LE177 at the Sandow Mine yielded only one Bulverde point and apparently did not see substantial use during the Late Archaic period (Ricklis 2001:150). A single sandy paste sherd was recovered from the Chesser site, but it is unclear if it relates to terminal Archaic or Late Prehistoric use of the site. In either case, ceramics were a less-prominent part of the material 
culture here than they were farther to the east and north. The limited faunal and macrobotanical remains recovered suggest reliance on Carya nuts and deer (Rogers 1999:28, 31-32; Rogers and Kotter 1995:42-45, C-1-10).

To the east, three sites along the Brazos River-Winnie's Mound (41BU17), 41BU16, and 41BU51-have significant Late Archaic components (Bowman 1985; Fields et al. 2004; Roemer and Carlson 1987). Perhaps most important, all three apparently contained cemeteries probably at least partly Late Archaic in age. Cemeteries here and elsewhere across the region perhaps represent increased population densities and definition of territories. The projectile point styles recovered-Bulverde, Darl, Dawson, Edgewood, Ensor, Fairland, Frio, Gary, Kent, Lange, Marcos, Pedernales, and Yarbrough-are a mix of types characteristic of central and eastern Texas. Winnie's Mound and 41BU51 each yielded a few sandy paste sherds, and 41BU16 contributed a larger ceramic collection that is hard to relate typologically to ceramics in surrounding regions.

Not far north on the Little River in Milam County, both 41MM340 and 41MM341 have Late Archaic components, although only the one at 41MM340 was investigated intensively ( $\mathrm{Ga}$ dus et al. 2003; Mahoney et al. 2003). This site, which was occupied from about 1400 to 400 B.C., contained many hearth features represented by both burned rock clusters and charcoal and burned clay concentrations. Subsistence data indicate that the hunter-gatherers who occupied the Little River valley at this time consumed the meat of a variety of fauna, including mussels, deer, bison, turtles, beaver, rabbits, raccoon, opossum, skunk, turkey, ducks, and fish. Botanical remains were not as abundant, although nutshell fragments indicate that hickory and pecan nuts were part of the diet. Most of the dart points belong to types that firmly tie the region to central Texas to the west at this time, including Darl, Ensor, Godley, Marcos, Marshall, and especially Pedernales. Some more-eastern types, such as Gary, Kent, and Yarbrough, are represented, however.

At the Gibbons Creek Mine on the east edge of the study area, most of the excavated sites have Late Archaic components, and Rogers (1995:167) suggests that this reflects "a less mobile population relying more heavily on the area's plant resources, particularly hickory nuts." Rock hearths are common at these sites, but other kinds of features are not. Not surprisingly, the most common dart point types-Gary, Kent, and Palmillas-show strong connections to the eastern part of the state rather than to central Texas (Rogers 1995:167). As at the Jewett Mine and Richland-Chambers Reservoir to the north, ceramics may have been added to the material culture during the latest Archaic. These early ceramics were sandy paste wares comparable to early ceramics elsewhere in southeastern Texas (Rogers 1995:167).

At Somerville Lake on Yegua Creek, the single site excavated, Erwin's Bridge, contained a strong Late Archaic component, although it was difficult to isolate it from the Late Prehistoric component (Peterson 1965). Most of the kinds of projectile points recovered-Bulverde, Castroville, Darl-like, Elam, Fairland, Palmillas, and Pedernales-resemble those from the Sandow Mine not far to the northwest, with both collections indicating ties to central Texas to the west. Erwin's Bridge yielded a small collection of ceramics, primarily sandy paste, but it is impossible to tell if these relate to the Late Archaic or Late Prehistoric occupations.

Moving farther south into the Colorado River basin, the Kennedy Bluffs and Bull Pen sites in Bastrop County and most of the tested sites at the Fayette Power Plant and the Cummins Creek Mine have Late Archaic components. Both the Kennedy Bluffs site and the Bull Pen site contained evidence of extensive use of burned rock features associated with point styles typical of central Texas to the west, especially Pedernales, with Bulverde, Marcos, Montell, and Marshall-like points also at Kennedy Bluffs and Ensor, Fairland, and Darl at Bull Pen (Bement et al. 1989:21-30, 37-44; Ensor and Mueller-Wille 1988:181-183). These sites have been interpreted as seasonal base camps used repeatedly by hunter-gatherers for a variety of maintenance, extractive, and processing tasks (Ensor and Mueller-Wille 1988:183-200). At the Fayette Power Plant, a number of sites yielded similar styles of pointsPedernales, Marshall, Ensor, Darl, and Fairland. The last three types were especially common and indicated "a marked increase in site utilization and exploitation of the local resources" during terminal Archaic times (Skelton 1977:125-126). Several of the tested sites at the Cummins Creek Mine contained Darl, Ensor, 
Pedernales, and Mahomet points and were interpreted as having been used as short-term campsites during the Late Archaic period (Kotter et al. 1991:118-119, 159-160, 177).

\section{Late Prehistoric Period}

Sites dating to the Late Prehistoric, after ca. A.D. 700, also are common across most of the region. As for the preceding period, good data on how Native Americans used the region comes from Richland-Chambers Reservoir and Lake Limestone and nearby Jewett Mine. Sites dating to this interval are frequent at RichlandChambers Reservoir, especially for the early half of the period, and it appears that there was a significant decline in population densities after about A.D. 1300 (McGregor and Bruseth 1987:245). The data suggest that most of the excavated sites with Late Prehistoric components were used for residential purposes (McGregor and Bruseth 1987:241, 244, 246), although there are some sites, for example the streamside concentrations of mussel shells and artifacts at $41 \mathrm{FT} 193$ and $41 \mathrm{NV} 139$, that probably had more-limited use. The house patterns at the Bird Point Island site point to intensive use by sedentary hunter-gatherers during the first half of the period, and other components that are contemporaneous, slightly earlier, or later (for example, at Adams Ranch, Bird Point Island, Irvine, and Little Cedar Creek) have middens and many features suggesting intensive use but no houses. These components may represent occupations that were seasonal in length. Macrobotanical remains point to use primarily of wild plant foods-hardwood nuts, a variety of seeds, tubers, and rhizomes (McGregor and Bruseth 1987:243). The only tropical cultigen is maize, and it occurs in very small quantities only in contexts dating to the last half of the period, so groups who lived in this area were predominantly hunters and gatherers. Alba, Scallorn, and Steiner arrow points were used during the early part of the period, and Perdiz and Cliffton points are more characteristic of the late part. Gary dart points may have been used through the early Late Prehistoric (McGregor and Bruseth 1987:183). Ceramics are moderately common and clearly relate to Caddoan wares, with most of the identified types (for example, Maydelle Incised, Poyner Engraved, and Weches Fingernail
Impressed) indicating contact with groups in the Neches River drainage, east of the Trinity.

Work at Lake Limestone along the Navasota River and the Jewett Mine in the uplands to the east identified 12 components dating predominantly to the Late Prehistoric period, although not all are well dated (Fields 1995:313-317; Gadus et al. 2002). Six are interpreted as residential bases, and the other 6 are procurement-processing locations. These sites suggest that the Late Prehistoric period saw a change in settlement strategies from the Late Archaic and that there were changes within the Late Prehistoric period as well. During the early part of the period, residential activities were increasingly restricted to lowland sites, while the uplands were used mostly for huntingrelated procurement and processing tasks. This pattern indicates that logistical strategies became more important, but there is no evidence that groups also became more sedentary within the upper Navasota River basin itself. Only one site, McGuire's Garden, contained the kinds of features and other remains that suggest permanent (or nearly so) occupation, with this unusually sedentary use dating to a short interval around A.D. 1300. During the late part of the period, the area apparently saw a return to forager-oriented hunter-gatherer strategies entailing more equable use of upland and lowland settings. Faunal remains indicate that deer, turtles, and rabbits were hunted commonly, and other small mammals, bison, fish, birds, lizards, and snakes were represented as well. Hickory nut shells are by far the most common plant remains. The only evidence for horticulture came from the McGuire's Garden site. Scallorn and Steiner are the most common early arrow point styles, and use of dart points appears to have persisted through the early part of the period (Fields 1995:314). Perdiz is the dominant later arrow point style. Ceramics occur widely but infrequently, being common at only a handful of sites that date mostly to the middle and late parts of the period. Nonetheless, they all relate strongly to Caddoan wares from east of the Trinity River, with the more-distinctive sherds showing typological affinities to early types such as Holly Fine Engraved and Weches Fingernail Impressed and later types such as Killough Pinched, Maydelle Incised, Patton Engraved, and Poyner Engraved. Because there are 
Caddoan ceramics present in these components but evidence for permanent occupations (i.e., structures) is scarce, Fields et al. (1991) suggested that Caddo Indians used most of these sites as base camps to support forays by hunting parties or other procurement and processing task groups, or perhaps groups in transit between the eastern and central parts of the state used them. It is equally plausible, however, that local hunter-gatherer groups created them and that the ceramics resulted from trade or borrowing of ideas about ceramic manufacture and decoration.

At the Calvert Mine in the uplands between the Brazos and Navasota Rivers, the primary component at the single excavated site, 41RT267, appears to date to the early Late Prehistoric period (Robinson and Turpin 1993:2369). It contained Alba, Granbury, and Scallorn points, as well as a single potsherd and several burned rock features, and was interpreted as having been used mostly as a hunting camp with occasional use as a domestic campsite (Robinson and Turpin 1993:71-72). Moving southwestward across the Brazos River, 41MM341 on the Little River has a significant early Late Prehistoric component dating mostly to A.D. 900-1300 (Gadus et al. 2003). This site contains numerous surface hearths, pit hearths, processing pits, shell lenses, burned rock concentrations, and possible postholes and appears to represent a residential campsite used repeatedly for a variety of activities. Arrow points are typed primarily as Scallorn, Alba, and Perdiz, and the site also contained many finely chipped bifacial knives. Three bone-tempered potsherds and one sandy paste sherd were recovered, but it is not clear if they belong with the early Late Prehistoric component or a much sparser later component. Analysis of the data from 41MM341 is currently under way and will add greatly to an understanding of how this part of the study area was used during this time; of particular note is what it may tell us about interaction between Caddoan groups of east Texas and groups living in central Texas.

Farther south at the Sandow Mine, all three excavated sites have Late Prehistoric components, but they do not appear to represent intensive use. Materials diagnostic of this period include small numbers of Alba, Cuney, Perdiz, and Scallorn points; ceramics are scarce to absent (Ricklis 2001:150; Rogers 1999:96; Rogers and Kotter 1995:136). At Somerville Lake not far to the southeast, arrow points typed as Alba, Cliffton, Granbury, Perdiz, Scallorn, and Young were recovered from the Erwin's Bridge site, along with a handful of undecorated potsherds (Peterson 1965:22-27, 36-43); small numbers of Alba, Scallorn, Perdiz, and Bonham points and sandy paste sherds were found at other sites that Thoms and Ahr (1996) recorded.

Eastward along the Brazos, early Late Prehistoric components represented by small numbers of Scallorn points, a few sandy paste sherds (at Winnie's Mound), and burials were documented at Winnie's Mound (41BU17) and 41BU51 (Bowman 1985:43, 50, 61-63; Fields et al. 2004). Alba, Perdiz, and Scallorn points were found at 41BU16 nearby, along with both sandy paste and bone- or grog-tempered ceramics (Roemer and Carlson 1987:80-93); some of the burials at 41BU16 could relate to the Late Prehistoric component as well.

At the Gibbons Creek Mine at the southeast edge of the study area, Late Prehistoric remains are well represented, with substantial occupations at 41GM281 and 41GM282 and more-limited occupations at several other sites (Rogers 1993:77, 102, 174, 214, 1994:154, 1995:138-143, 164-165). The predominant early and late arrow point styles are Scallorn and Perdiz, respectively. The ceramics from most of the excavated sites (Rogers 1993:102, 160-173, 210-212, 1994, 1995:108-123, 168-171) are the sandy paste ware that occurs throughout southeast Texas, first in late Archaic (or Woodland or Early Ceramic) contexts and then in some Late Prehistoric contexts (e.g., on the upper coast). Two sites (41GM281 and 41GM282) also have sizable samples of pottery tempered with grog or bone. Some of these probably are related to the Late Prehistoric San Jacinto ware that occurs on the upper coast to the east and southeast, and small numbers of sherds bear designs similar to those seen on Caddoan pottery to the northeast. Subsistence data from the Gibbons Creek Mine are especially sparse, but hardwood nutshells occur in most sites and liliaceous bulb fragments were recovered from a single site (Rogers 1993:74, 124, 214, 1994:120, 149, 1995:56, 153). Consistent with the lack of cultigens at Gibbons Creek is the low stable carbon isotope value on human remains from a Late Prehistoric burial at 41GM205 (Rogers 1993:D1 through D-3). The combined evidence indi- 
cates that, for the most part, the Gibbons Creek sites represent short-term residential occupations by hunter-gatherers.

In the Colorado River basin at the south end of the study area, Late Prehistoric components do not seem to be well represented. At the Cummins Creek Mine, only one minor Late Prehistoric occupation is represented by a single untyped arrow point from one of the four sites tested (Kotter et al. 1991:154). The Black Hopper, Kennedy Bluffs, and Bull Pen sites all contained sparse Late Prehistoric materials indicating limited occupations; arrow point types consisted of Granbury, Perdiz, and Scallorn, with none of the sites yielding ceramics (Bement et al. 1989:47; Ensor and Mueller-Wille 1988:116118; Fullem 1977:12-13). One of the most substantial excavated Late Prehistoric components in this area was at the Cedar Bridge site at the Fayette Power Plant (Skelton 1977:127-128), where a Toyah occupation represented by Perdiz and Cliffton arrow points, bone-tempered ceramics, and bison bones was sampled. Another important Late Prehistoric component in the area was at the Frisch Auf! site, where Scallorn points and bone-tempered ceramics were found in association with a cemetery (Hester and Collins 1969).

\section{Historic Period}

Native American archeological materials dating to the protohistoric and early historic periods are scarce in southern east-central Texas. In fact, materials of this age are so rare as to be almost invisible archeologically in the project areas discussed above. But ethnohistoric accounts make it clear that historic Native Americans, both resident groups and immigrants, occupied the area (Bolton 1970; Campbell 1988; Newcomb 1993). Further, two historic routes from south Texas to east TexasCamino de los Tejas and Camino Arriba-passed through present-day Brazos, Burleson, Leon, Madison, Milam, and Robertson Counties by the seventeenth and eighteenth centuries (McGraw et al. 1991:9). In the late 1740s and early 1750s, the Spanish located three missions-San Francisco Xavier de Horcasitas, San Ildefonso, and Nuestra Señora de la Candelaria-and a presidio (San Francisco Xavier de Gigedo) near one of these routes, not far from where Brushy Creek joins the San Gabriel River in Milam
County (Gilmore 1996a, 1996b). The impetus for this came when members of the Deadose, Ervipiame, Mayeye, and Yojuane asked that a mission be established in their territory. Other Native American groups reportedly associated with the missions were the Akokisa, Asinia, Bidai, Coco, Nabedache, and Top. For a variety of reasons, the Spanish had abandoned their efforts in this region by the mid-1750s (Newcomb 1993:16-17).

\section{Central Blackland Prairie}

\section{Previous Research}

The archeology of the central Blackland Prairie is not well understood because few largescale projects involving excavations at numerous sites have been undertaken. But enough archeological work has been done on the northern and eastern margins of the Waco District to provide some insights into the culture history of this area. Among the projects that have contributed important information are Navarro Mills Reservoir and Aquilla Lake in Hill County (Brown 1987; Duffield 1963) and the Superconducting Super Collider and Bardwell Lake in Ellis County (Sorrow 1966; Yedlowski et al. 1998).

Several important investigations have been undertaken on or adjacent to the Blackland Prairie in the eastern part of the Austin District, particularly the work at Granger Lake in Williamson County (Bond 1978; Hays 1982; Prewitt 1974, 1982), the Bessie Kruze site in Williamson County (Johnson 2000), the Toyah Bluff site in Travis County (Karbula et al. 2001), the Armstrong site in Caldwell County (Schroeder et. al 1999), Rice's Crossing in Williamson County (Brownlow 2000), and the as-yet-unreported Rowe Valley site in Williamson County. As Johnson's (2000) excellent summary notes, however, the archeology of this part of the Blackland Prairie has more in common with that of the Edwards Plateau and central Texas to the west (as described below). Hence, the discussion below focuses on the rest of the central Blackland Prairie.

\section{Paleoindian Period}

Sites such as Horn Shelter No. 2 and Wilson-Leonard have provided substantial 
information on the Paleoindian period for the area to the west of this region, but there are no excavated and reported Paleoindian components on the central Blackland Prairie. Nonetheless, a variety of early points have been found, largely in surface contexts, and it is clear that this part of Texas was used throughout the Paleoindian period (ca. 11,500-8800 B.P.). Presumably, low population densities and high residential mobility characterized these early hunter-gatherer groups. Paleoindian materials from the region include several San Patrice or Brazos Fishtail and Plainview points from Aquilla Lake (Brown 1987:44-1 through 44-2); a handful of points typed as Clovis, Dalton, Golondrina, Plainview, and San Patrice, along with several untyped lanceolate specimens, in collections by C. K. Chandler and other avocational archeologists from sites mostly in Ellis County (Yedlowski et al. 1998:519-520); a cache of 23 prismatic blades from a site in Navarro County (Young and Collins 1989); and probably the Brookeen Creek cache of 173 blades and flakes from Hill County (Mallouf 1981).

\section{Archaic Period}

Some excavated sites in the region have components dating to the Archaic period (ca. $8800-1250$ B.P.), but materials dating to the early and middle parts of the period are not very abundant. A variety of projectile point styles traditionally associated with the Early and Middle Archaic periods of central Texas-such as Andice, Angostura, Bell, Gower, Hoxie, Martindale, Nolan, Travis, and Uvalde-were identified in private artifact collections analyzed for the Superconducting Super Collider project just to the north in Ellis County (Yedlowski et al. 1998:520). These points are few in number, however, and do not appear to represent major occupations of this part of the Blackland Prairie. Unequivocal early point styles were even scarcer at the nearby Pecan Springs site at Bardswell Reservoir and the Strawn Creek site at Navarro Mills Reservoir, with a Hoxie point from Pecan Springs being the clearest example (Duffield 1963; Sorrow 1966). Similarly, Early to Middle Archaic points-including Angostura, Bell/Andice, Gower, Hoxie (?), and Martindale-were found only in small numbers at Aquilla Lake (Brown 1987:44-12 through 4421 , suggesting limited use of the valleys of
Aquilla and Hackberry Creeks during this time. Given the limited information available for this part of the period, it is difficult to say much about adaptations and lifeways. It does appear, however, that the region was used in a limited fashion, presumably reflecting low population densities among mobile hunter-gatherers.

A different picture is presented for the latter part of the Archaic period-that is, after about 4000 B.P.- -in that more-intensive occupation is suggested. Both the Pecan Springs and Strawn Creek sites yielded such Late Archaic point types as Dawson, Gary, and Yarbrough, although they tended to be mixed with materials from later occupations (Duffield 1963:60-62; Sorrow 1966:56-61). The surface collections analyzed during the Superconducting Super Collider project also contained these types, as well other Late Archaic types common to central Texas-such as Bulverde, Darl, Ensor, Marcos, Marshall, Montell, and Pedernalesand a variety of probable Late Archaic forms more characteristic of north-central and eastern Texas, such as Carrollton, Edgewood, Elam, Ellis, Kent, and Neches River (Yedlowski et al. 1998:520-521). Noting the relatively high frequency of Late Archaic projectile points, Yedlowski et al. (1998:527-528, 533) suggest that the region saw an increase in use by huntergatherers as a result of moister climatic conditions than before, presumably associated with greater productivity in subsistence resources. They also note that, although the projectile point evidence indicates interaction with groups living in central Texas proper, larger proportions of points indicate affinities with eastern Texas than during the Early and Middle Archaic. Brown (1987:44-22 through 44-26) presents similar conclusions concerning an increase in occupational intensity (increased population?) and increased interaction to the north and east during the Late Archaic for the Aquilla Lake area based on an increase in the number of sites with Late Archaic diagnostics and the dominance of the Gary dart point type.

\section{Late Prehistoric Period}

Sites dating to the Late Prehistoric period, after ca. 1250 B.P., also are relatively common. The collections analyzed during the Superconducting Super Collider project contain substantial numbers of both early (e.g., Alba, Bonham, 
Catahoula, Colbert, Scallorn, and Steiner) and late (e.g., Cliffton and Perdiz) arrow points, but Yedlowski et al. (1998:521, 527) note that early arrow points are more frequent, perhaps reflecting continued high population densities from the Late Archaic period. Other than the Perdiz and Scallorn types, which have such widespread distributions, the arrow point styles suggest strong ties to the east and north. The limited ceramic samples, containing sherds reminiscent of types such as Killough Pinched, Maydelle Incised, Poyner Engraved, and Weches Fingernail Impressed also support interaction with Caddoan groups to the east (Yedlowski et al. 1998:521-522). The Strawn Creek site presents a similar picture, with most of the typed arrow points dating to the first half of the Late Prehistoric period and the more-distinctive ceramics in the small collection relating to the early Caddoan types Crockett Curvilinear Incised and Weches Fingernail Impressed (Duffield 1963).

Occupations dating to the early and late parts of the Late Prehistoric period also are represented at Aquilla Lake at the western edge of the Blackland Prairie, with the strongest components at the McDonald and Brazil sites (Brown 1987:44-27). Almost all of the small ceramic sample was from one site, McDonald. Among the ceramics are specimens that could be related to the Caddoan types Canton Incised, Kiam Incised, and Maydelle Incised, pointing to interaction with groups living to the east and northeast. The faunal sample from the McDonald site indicates that these huntergatherers relied on deer, turtles, fish, and mussels; bison were used only during the latter part of the period (Brown 1987:38-144).

\section{Historic Period}

There is ample historical and archeological evidence of Native American use of at least the margins of the central Blackland Prairie during the protohistoric and early historic periods. As noted under the discussion of east-central Texas above, the Spanish located three missions (San Francisco Xavier de Horcasitas, San Ildefonso, and Nuestra Señora de la Candelaria) and a presidio (San Francisco Xavier de Gigedo) near the confluence of Brushy Creek and the San Gabriel River in Milam County in the late 1740 s and early 1750 s in response to requests from immigrant Ervipiame, Deadose, Mayeye, and Yojuane (Gilmore 1996a, 1996b). Historical accounts place the Mayeye in the area southeast of Waco much earlier than this, by 1687 , and the 2,000-strong Ervipiame and associated groups, known as Ranchería Grande, were in the area of Milam County by 1716 (Newcomb 1993:24, 26). The Tonkawa also probably roamed the central Blackland Prairie during the eighteenth century, for they were documented in northwestern Limestone County in 1778 and elsewhere in the region (Newcomb 1993:27-28). Archeological evidence for Native American use of the area consists of a number of sites that have been associated with Wichita groups who moved southward into the region in the eighteenth century. Among these are the Vinson site in Limestone County (Smith 1993), as well as sites near Waco and Whitney Lake (see discussion of central Texas below).

\section{Northern and Northeastern Portions of Central Texas}

\section{Previous Research}

The archeological record of the central Texas region is known from decades of investigations at various stratified open-air sites and rockshelters. Traditionally, the central Texas archeological region has included the Llano Uplift, Lampasas Cut Plain, eastern Edwards Plateau and its highly dissected eastern margin, and adjacent prairie margin (e.g., Prewitt 1981; Suhm 1960), which encompass large portions of the Austin, Brownwood, and Waco Districts. In the Waco District, sites that have contributed important information include the Landslide site (Sorrow et al. 1967), the Youngsport site (Shafer 1963), the Gault site (Collins and Brown 2000), Kyle Rockshelter (Jelks 1962), and several sites at Fort Hood (see Kleinbach et al. 1999; Mehalchick et al. 1999, 2000) and Waco Lake (Scott et al. 2002; Story and Shafer 1965). These sites have contributed to a better understanding of the prehistory of central Texas, with projectile point styles from some of these sites suggesting influences and contacts to varying degrees over time with areas to the east and northeast (cf. Collins 1995; Johnson and Goode 1994).

To the west in the Brownwood District, sites that have contributed important information include the Finis Frost site (Green and Hester 
1973), the McCann site (Preston 1969), and several sites (41CN19, 41CN27, and 41CN95) at O. H. Ivie Reservoir in Coleman County (Lintz et al. 1993; Treece et al. 1993a, 1993b). Like some of the sites in the Waco District, some sites in the Brownwood District suggest influences and contacts to varying degrees over time with areas outside central Texas, such as the High Plains to the west.

To the south and southeast in the Austin District, sites that have contributed important information include the Wilson-Leonard site (Collins 1998), the Sleeper site (Johnson 1991), the Loeve-Fox site (Prewitt 1982), the Barton and Mustang Branch sites along Onion Creek (Ricklis and Collins 1994), and Smith Rockshelter (Suhm 1957). As in the other two districts, some of the sites in the Austin District suggest influences and contacts to varying degrees over time with areas outside central Texas, such as the Lower Pecos and Gulf Coastal Plain (Collins 1995; Johnson and Goode 1994). For more-complete bibliographies concerning archeological work done in the central Texas region, see Black (1989b), Collins (1995), and Johnson and Goode (1994).

\section{Paleoindian Period}

Paleoindian (11,500-8800 B.P.) occupations are represented by surficial and deeply buried sites, rockshelter sites, and isolated artifacts. The period often is described as having been characterized by small but highly mobile bands of foragers who were specialized hunters of Pleistocene megafauna. But a more accurate view of Paleoindian life probably includes the use of a much wider array of resources (Meltzer and Bever 1995:59), including small fauna and plant foods. Recent investigations at the Wilson-Leonard site support this view and have challenged the fundamental defining criterion of the Paleoindian period, that of artifacts in association with late Pleistocene megafauna (Collins 1998). Additionally, longstanding ideas about aspects of Paleoindian technologies are being challenged.

Collins (1995) divides the Paleoindian period into early and late subperiods. Two projectile point styles, Clovis and Folsom, are included in the early subperiod. Clovis chipped stone artifact assemblages, including the diagnostic fluted lanceolate Clovis point, were produced by bifacial, flake, and prismatic-blade techniques on high-quality and often-times exotic lithic materials (Collins 1990). Along with chipped stone artifacts, Clovis assemblages include engraved stones, bone and ivory points, stone bolas, and ochre (Collins 1995:381; Collins et al. 1992). Clovis points are found evenly distributed along the eastern edge of the Edwards Plateau, where springs and outcrops of chertbearing limestone are common (Meltzer and Bever 1995:58). Clovis, as well as a number of later Paleoindian dart points, have been recovered from the Gault site in Bell County (Collins and Brown 2000), the Triple S Ranch site in Hamilton County (Hatfield 1997), and San Marcos Springs in Hays County (Takac 1991). Probable Clovis polyhedral blade cores have been found in Hamilton County, as well as a blade and blade core in Comanche County (Goode and Mallouf 1991; Green 1963). Analyses of Clovis artifacts and site types suggest that Clovis peoples were well-adapted, generalized hunter-gatherers with the technology to hunt larger game but not rely on it solely.

In contrast, Folsom tool kits-consisting of fluted Folsom points, thin unfluted (Midland) points, large thin bifaces, and end scrapers-are more indicative of specialized hunting, particularly of bison (Collins 1995:382). Folsom points have been recovered from Horn Shelter No. 2 along the Brazos River (Redder 1985; Watt 1978), and Folsom-age materials have been recovered from the Gault site. A Midland point was recovered from the Wilson-Leonard site.

Postdating Clovis and Folsom points in the archeological record are a series of dart point styles for which the temporal, technological, or cultural significance is unclear. Many of these dart point styles are unfluted and lanceolate. Often, the Plainview type name is assigned these lanceolate dart points, but Collins (1995:382) has noted that many of these points typed as Plainview do not parallel Plainview type-site points in thinness and flaking technology. Investigations at the Wilson-Leonard site (see Collins 1998) and a statistical analysis of a large sample of unfluted lanceolate points by Kerr and Dial (1998) have shed some light on this issue. At Wilson-Leonard, the Paleoindian projectile point sequence includes an expanding-stem dart point termed Wilson, which dates to ca. 10,000 9500 B.P. Postdating the Wilson component is a series of unfluted lanceolate points referred to 
as Angostura, Golondrina-Barber, and St. Mary's Hall, but their chronological sequence is poorly understood. Several dart point styles were recovered from Horn Shelter No. 2, including Dalton, Plainview, San Patrice, and Scottsbluff (Watt's [1978] Brazos Fishtail points) types, but like many of the unfluted lanceolate points, the chronological position and cultural significance of Dalton and San Patrice dart points remain nebulous. Regardless, it has become clear that the artifact and feature assemblages of the later Paleoindian subperiod appear to be Archaic-like in nature and in many ways may represent a transition between the early Paleoindian and succeeding Archaic periods (Collins 1995:382).

\section{Archaic Period}

The Archaic period dates from ca. 8800 to 1300-1200 B.P. (Collins 1995). The Archaic period generally is believed to represent a shift toward the hunting and gathering of a wider array of animal and plant resources and a decrease in group mobility (Willey and Phillips 1958:107-108). In the eastern and southwestern United States and on the Great Plains, the Archaic period is succeeded by the development of horticultural-based, semisedentary to sedentary societies. In these areas, the Archaic truly represents a developmental stage of adaptation as Willey and Phillips (1958) defined it. For central Texas, this notion of the Archaic is somewhat problematic. An increasing amount of evidence suggests that Archaic-like adaptations were in place beforebefore the Archaic chronological period (see Collins 1995:381-382, 1998) and that these practices continued into the succeeding Late Prehistoric period (Collins 1995:385; Prewitt 1981:74; Treece et al. 1993b). Thus, in this region the Archaic period is not a developmental stage but an arbitrary chronological construct and projectile point style sequence. This sequence is based on several decades of archeological investigations at stratified Archaic sites along the eastern and southern margins of the Edwards Plateau. Collins (1995) and Johnson and Goode (1994) have divided this sequence into three parts-early, middle, and late-based on perceived (though not fully agreed on by all scholars) technological, environmental, and adaptive changes.

Early Archaic (8800-6000 B.P.) sites are small, and their tool assemblages are diverse
(Weir 1976:115-122), suggesting that populations were highly mobile and densities low (Prewitt 1985:217). It has been noted that Early Archaic sites are concentrated along the eastern and southern margins of the Edwards Plateau (Johnson and Goode 1994; McKinney 1981). This distribution may indicate climatic conditions at the time, given that these areas have more reliable water sources and a more-diverse resource base than other parts of the region. Early Archaic projectile point styles include Angostura, Gower, Hoxie, Martindale, Uvalde, and Wells. Manos, metates, hammerstones, Clear Fork and Guadalupe bifaces, and a variety of other bifacial and unifacial tools are common to Early Archaic assemblages. The construction and use of rock hearths and ovens, which saw limited use during late Paleoindian times, became commonplace. The use of rock features suggests that the retention of heat and its slow release over an extended period of time were an important aspect of food processing and cooking and reflects a specialized subsistence strategy during the early Archaic. Such a practice probably was related to cooking plant foods, particularly roots and bulbs, many of which must be subjected to prolonged periods of cooking to render them consumable and digestible (Black et al. 1997:257; Wandsnider 1997; Wilson 1930). Botanical remains, as well as other organic materials, are often poorly preserved in Early Archaic sites, so the range of plant foods exploited and their level of importance in the overall subsistence strategy are poorly understood. But the recovery of charred wild hyacinth (Camassia scilloides) bulbs from an Early Archaic feature at the Wilson-Leonard site provides some insights into the types of plant foods used (Collins 1998). Significant early Archaic sites include the Youngsport site in Bell County (Shafer 1963), which yielded Gower and Wells dart points from deeply buried contexts, and the Jetta Court site in Travis County (Wesolowsky et al. 1976).

During the Middle Archaic period (6000 4000 B.P.), the number and distribution of sites, as well as site size, increased because of probable increases in population densities (Prewitt 1981:73; Weir 1976:124, 135). Macro-bands may have formed at least seasonally, or an increased number of small groups may have used the same sites for longer periods of time (Weir 1976:130 131). A greater reliance on plant foods is 
suggested by the presence of burned rock middens toward the end of the Middle Archaic, although tool kits still imply a strong reliance on hunting (Prewitt 1985:222-226). Middle Archaic projectile point styles include Andice, Baird, Bell, Nolan, Taylor, and Travis. Bell and Andice points reflect a shift in lithic technology from the preceding Early Archaic Martindale and Uvalde point styles (Collins 1995:384). Johnson and Goode (1994:25) suggest that the Bell and Andice darts are parts of a specialized bison-hunting tool kit. They also suggest that the beginning of the Middle Archaic was marked by an influx of bison and bison-hunting groups from the Eastern Woodland margins during a slightly more-mesic period. Bell points and bison remains were recovered from the Landslide site in Bell County (Sorrow et al. 1967). Bison disappeared as more-xeric conditions returned during the later part of the middle Archaic. Later middle Archaic projectile point styles represent another shift in lithic technology (Collins 1995:384; Johnson and Goode 1994:27). Prewitt (personal communication 2000) postulates that Travis and Nolan points are similar in production and morphology to projectile points from the Lower Pecos region. Such characteristics as beveled stems and overall morphology may have originated in the Lower Pecos because these elements appeared earlier in the Lower Pecos than they did in central Texas. Shafer's (1963:67) surprise that Nolan points, which are more common in sites to the south and west, were not found in greater numbers at the Youngsport site might support the idea that bearers of these darts came out of the Lower Pecos and moved into adjacent portions of central Texas but did not use all portions of central Texas equally. At the same time, a shift to more-xeric conditions bore witness to the formation of burned rock middens. This is because of a probable intensified use of a specific resource (geophytic or xerophytic plants) or resource patches, which resulted in the debris of multiple rock ovens and hearths accumulating as middens on stable to slowly aggrading surfaces, as suggested by Kelley and Campbell (1942) many years ago. Johnson and Goode (1994:26) believe that the dry conditions promoted the spread of yuccas and sotols, and that it was these plants that were collected and cooked in large rock ovens by late Middle Archaic peoples.

During the succeeding Late Archaic period
(4000 to 1300-1200 B.P.), populations continued to increase (Prewitt 1985:217), and the archeological record is more visible (Treece et al. 1993a:588). Within stratified Archaic sitessuch as Youngsport, the Britton site in McLennan County (Story and Shafer 1965), the Steele site in Hill County (Stephenson 1970), and the Loeve-Fox site in Williamson County (Prewitt 1982) - the Late Archaic components contain the densest concentrations of cultural materials. The establishment of large cemeteries along drainages suggests strong territorial ties by certain groups (Story 1985a:40). A variety of projectile point styles appeared throughout the Late Archaic period. Johnson and Goode (1994:29-35) divide the Late Archaic into two parts based on increased population densities and perceived evidence of Eastern Woodland ceremonial rituals and religious ideological influences. Middle Archaic subsistence technology, including the use of rock and earth ovens, continued into the Late Archaic period. Collins (1995:384) states that at the beginning of the Late Archaic period, the use of rock ovens and the resultant formation of burned rock middens reached its zenith and that the use of rock and earth ovens declined during the latter half of the Late Archaic. But there is mounting evidence that midden formation culminated much later and that this high level of rock- and earth-oven use continued into the early Late Prehistoric period (Black et al. 1997:270-284; Kleinbach et al. 1995:795). A picture of prevalent burned rock midden development in the eastern part of the central Texas region after 2000 B.P. is gradually becoming clear. This scenario parallels the widely recognized occurrence of post-2000 B.P. middens in the western reaches of the Edwards Plateau (see Goode 1991; Treece et al. 1993a). The use of rock and earth ovens for processing and cooking plant foods suggests that this technology was part of a generalized foraging strategy. The amount of energy involved in collecting plants, constructing hot-rock cooking appliances, and gathering fuel ranks most plant foods relatively low based on the resulting caloric return (Dering 1999). This suggests that plant foods were part of a broad-based diet (Kibler and Scott 2000:134) or part of a generalized foraging strategy, an idea put forth earlier by Prewitt (1981). But at times during the Late Archaic, this generalized foraging strategy appears to have been marked by shifts to a specialized economy fo- 
cused on bison hunting (Kibler and Scott 2000:125-137). Castroville, Montell, and Marcos dart points are elements of tool kits often associated with bison hunting (Collins 1968). Archeological evidence of this association is seen at Bonfire Shelter in Val Verde County (Dibble and Lorrain 1968), Jonas Terrace (Johnson 1995), Oblate Rockshelter (Johnson et al 1962:116), John Ischy (Sorrow 1969), and Panther Springs Creek (Black and McGraw 1985).

The Archaic period represents a hunting and gathering way of life that was successful and that remained virtually unchanged for more than 7,500 years. This notion is based in part on fairly consistent artifact and tool assemblages through time and localities and resource patches that were used continually for several millennia, as witnessed by the formation of burned rock middens. This pattern of generalized foraging, though marked by brief shifts to a heavy reliance on bison, continued almost unchanged into the succeeding Late Prehistoric period.

\section{Late Prehistoric Period}

The Late Prehistoric period (1300-1200 to 300 B.P.) was marked by the introduction of the bow and arrow and later, ceramics, into central Texas. Population densities dropped considerably from their Late Archaic peak (Prewitt 1985:217). Subsistence strategies did not differ greatly from the preceding period, although bison again became an important economic resource during the late part of the Late Prehistoric period (Prewitt 1981:74). The use of rock and earth ovens for plant food processing and the subsequent development of burned rock middens continued throughout the Late Prehistoric period (Black et al. 1997; Kleinbach et al. 1995:795; Treece at al. 1993a). Horticulture came into play very late in the region but was of minor importance to overall subsistence strategies (Collins 1995:385).

In central Texas, the Late Prehistoric period generally is associated with the Austin and Toyah phases (Jelks 1962; Prewitt 1981:82-84), though Story (1990:364) argues for a period or horizon characterized by Alba points and early Caddoan-like pottery intermediate between the Austin and Toyah phases for the middle Brazos River basin. Evidence of this proposed archeological manifestation was found at the Chupik site in McLennan County (Watt 1953). There is also evidence from the Colorado River basin indicating that Garza Complex peoples of the High Plains escarpment area frequented the morewestern portions of the region during Toyah times (Treece et al. 1993b). Exotic materials, such as ceramics and obsidian, from areas farther west in the Trans-Pecos and New Mexico are common in this part of the region. For the most part, however, the Late Prehistoric period of the region is dominated by the Austin and Toyah phases.

Much of what is known about the Austin and Toyah phases comes from rockshelters in and around Whitney Lake in Bosque and Hill Counties (see Jelks 1962; Stephenson 1970), though Austin and Toyah phase horizon markersScallorn-Edwards arrow points for Austin and Perdiz arrow points for Toyah-are distributed across most of the state. The introduction of Scallorn and Edwards arrow points into central Texas often was marked by evidence of violence and conflict because many excavated burials contain these point tips in contexts indicating they were the cause of death (Prewitt 1981:83). Subsistence strategies and technologies (other than arrow points) did not change much from the preceding Late Archaic period. This continuity is recognized by Prewitt's (1981) use of the term "Neoarchaic." In fact, Johnson and Goode (1994:39-40) and Collins (1995:385) state that the break between the Late Archaic and the Late Prehistoric could be represented easily and appropriately by the break between the Austin and Toyah phases. Assemblages from sites like 41CN19 suggest that both upland and riparian environments were used and that a wide range of resources was exploited, though bison are notably absent from the assemblage (Treece et al. 1993a:562-563).

Around 1000-750 B.P., slightly more-xeric or drought-prone climatic conditions returned to the region, and bison returned in large numbers (Huebner 1991; Toomey et al. 1993). Using this vast resource, Toyah peoples were equipped with Perdiz point-tipped arrows, end scrapers, four-beveled-edge knives, and plain bonetempered ceramics. The technology and subsistence strategies of the Toyah phase represent a completely different tradition from the preceding Austin phase. Collins (1995:388) states that the formation of burned rock middens ceased because bison hunting and group mobility obtained a level of importance not witnessed since 
Folsom times. Although the importance of bison hunting and high group mobility hardly can be disputed, the cessation of burned rock midden development during the Toyah phase is tenuous. A recent examination of Toyah-age radiocarbon assays and assemblages by Black et al. (1997) suggests that their association with burned rock middens represents more than a "thin veneer" capping Archaic-age features. Black et al. (1997) claim that burned rock midden formation, although not as prevalent as in earlier periods, played a role in the adaptive strategies of Toyah peoples.

Contact between Toyah peoples and Caddoan groups to the east and northeast is represented by Caddoan ceramics in site assemblages, particularly in the eastern peripheral areas of central Texas (e.g., Ricklis and Collins 1994:305-311; Stephenson 1970). In morewestern parts of the region, not only did contact with Garza Complex groups occur, but it also has been suggested that Toyah and Garza peoples used the region simultaneously (Treece et al. 1993b).

\section{Historic Period}

Historical accounts of Native Americans and their interactions with Europeans, the Republic of Mexico, the Texas Republic, and the United States throughout the region are provided by Campbell (1988), Foster (1995), Jelks (1970), Ricklis and Collins (1994), and Wade (1999). Much of the early available information on aboriginal groups comes from the late seventeenth and early eighteenth centuries, during which time the Spanish moved northward to establish missions on their northern frontier, and the French established a trading post near the Great Bend of the Red River and a short-lived colony along the central Texas coast. Although contact between Europeans and Native Americans became more permanent at this time, the disastrous disruptions of native social structures and economic systems by disease and oftentimes hostile encounters were already under way. Encroached on by the Spanish from the south and groups like the Apache from the north, many Native American groups sought refuge in the central Texas region. As a result, many groups that the Spanish encountered probably were not native to the region.

Within and close to the southern part of the study area, Campbell (1988) identifies the Cantona and Catqueza as two probable groups native to the region, but he also identifies groups from the Trans-Pecos and northeastern Mexico-such as the Jumano, Cíbola, Mescal, and Simaomo-within central Texas. Many of the groups encountered by the Spanish in this area were not socially or politically autonomous and often shared encampments, such as the large camp along the San Marcos River witnessed by the Terán de los Ríos expedition in 1691 (Foster 1995:57-58). It appears that these fusions of groups, which at times included the Hasinai Caddo, often occurred seasonally and were linked to bison hunting.

In the northern part of the study area, Wichita-speaking groups consisting of the Tawakoni, Waco, and Kichai; Caddoan tribes composed of the Anadarko, Hasinai, and Kadohadacho; and the Tonkawa occupied the area historically. As in the southern part of the study area, many of these groups migrated into the area early in the Historic period. The ancestral Tonkawa moved in probably from northcentral Oklahoma in the seventeenth century (Campbell 1988:75; Newcomb 1993:27). At the same time, Wichita groups were also moving into northern Texas (Newcomb 1993). Athanase de Mézières's expeditions along the Brazos River in the 1770s encountered two large Tawakoni villages along a stretch from presentday Waco to the vicinity of the Nolan River (Jelks 1970; Krieger 1996). Based on archeological evidence and historical documents, the Stansbury site near Whitney Lake was occupied by the Tawakoni in the 1770s-1780s (Jelks 1970), and Story (1985b) identifies a number of other sites (e.g., Gas Plant, Stone, and Walton) in the Waco area that appear to be associated with occupations by Wichita groups. By this time Native American populations were decimated, and many groups lost their ethnic identity as they were forced into conglomerations of groups for defense or into the Spanish missions by the southward-moving Apaches and later Comanches. The Apaches, and especially the Comanches, dominated the landscape by the early 1800 s, raiding other Native American groups and the ever-increasing number of EuroAmerican settlements. By the 1870 s, the remaining groups of Tonkawa, Apache, and Comanches were removed from the area and placed on reservations in Indian territory. 
Historically, Apaches and later the Kiowa and Comanches occupied the western part of the study area (Leffler 1996a, 1996b). By the late eighteenth century, Comanches of the Penateka band had complete control of the area, but as in other areas, the Comanches were removed and placed on reservations by the 1870 s.

\section{North-Central Texas}

\section{Previous Research}

This synopsis deals with most of the Fort Worth District and adjacent areas. Previous archeological investigations within this region vary in intensity and quality. Much work has been done in the Trinity River drainage, whereas significantly less work has taken place in the western and southwestern parts. For instance, on the East Fork of the Trinity River east of the Fort Worth District, several projects have made significant contributions, including Lavon Lake (Dawson and Sullivan 1973; Lynott 1975; Stephenson 1949) and Lake Ray Hubbard (Harris and Suhm 1963; Lorrain and Hoffrichter 1968; Ross 1966). Significant archeological projects on the upper Elm Fork of the Trinity in the Dallas-Fort Worth-Denton area include Ray Roberts Reservoir (Ferring 2001; Ferring and Yates 1997; Prikryl and Yates 1987; Skinner et al. 1982), Lewisville Lake (Brown and Lebo 1991; Ferring and Yates 1998; Stephenson 1950), and Grapevine Lake (Ferring 1975; Morgan 1975). Along the West Fork of the Trinity River and its tributaries, intensive investigations have occurred only at Mountain Creek Lake (Peter and McGregor 1988). Investigations in the Brazos River basin as it passes through the southwestern part of the Fort Worth District include those at Lake Granbury (Skinner 1971) and Possum Kingdom Lake (Brayshaw 1970; Hughes 1942; Krieger 1946).

Much of the information generated by the reservoir investigations has yet to be synthesized. The following discussion of the prehistory of north-central Texas draws on the few synthetic and summary sources available, especially those by Prikryl (1990, 1993). Story's (1990) summary of archeology on the east Texas Gulf coastal plain also draws on some of the work done in the upper Trinity basin, and Lynott's (1981) discussion of prehistoric adaptations in the Cross Timbers, Grand Prairie, and Rolling Plains provides connections to an overview by Hofman et al. (1989) of southern Great Plains archeology.

\section{Paleoindian Period}

As with many other areas of Texas, Paleoindian materials in north-central Texas often are found in surface contexts or mixed with later materials. The generally low density of Paleoindian artifacts and sites and the tendency for projectile points to be made from nonlocal lithics have led investigators to characterize these populations as highly mobile with low regional densities (Lynott 1981:100-101). Megafauna fossil finds within the region have led some investigators to conclude that subsistence practices of Paleoindian peoples were linked to mammoth and bison. But no kill or butchering sites similar to those identified for the southern Plains have ever been discovered (Prikryl 1990, 1993).

Generally, the Paleoindian period in northcentral Texas is considered to extend from ca. 10,000 to 6500 B.C. (Prikryl 1993:199). Point types often found that can be associated with the early to late parts of the period include Clovis, Dalton, Folsom, Plainview, San Patrice, and Scottsbluff. The most common types recognized are Dalton and Plainview (Prikryl 1990). Most of the recorded Paleoindian sites cluster in the upper Trinity drainage where the most intensive archeological investigations have taken place, though often these sites consist of no more than one or two points. But the Acton site, in Hood County situated on a $\mathrm{T}_{2}$ terrace of the Brazos River overlooking Lake Granbury, is significant for the number of Plainview and Dalton (Meserve) points it produced $(\mathrm{n}=72)$. A variety of other lithic tools such as gouges, scrapers, and burins also were recovered. Unfortunately, the Paleoindian occupation could not be isolated from Archaic-period occupations of the site.

Interestingly, the only two investigated sites in north-central Texas with apparently discrete Paleoindian components are early because both produced Clovis projectile points. These sites are the Lewisville and Aubrey sites situated just east of the northern part of the Fort Worth District. The Lewisville site contained 27 hearth features with an associated Clovis point 
and other sparse lithics in a near-surface context (Crook and Harris 1957, 1958; Story 1990:182-184), and the Aubrey site contained a Clovis component with cultural features and concentrations of lithics and animal bones buried 7-9 $\mathrm{m}$ deep on the Elm Fork floodplain (Ferring 2001). Both sites also contained a variety of faunal remains both large and small, although only small game, the largest being white-tailed deer, can be associated comfortably with the Clovis occupation at the Lewisville site. Bison bones were recovered from Aubrey, but the preponderance of smaller game suggests a more-generalized pattern of foraging as opposed to the reliance on mammoth and bison apparently demonstrated at Clovis sites on the southern Plains (Hofman et al. 1989:31-32). Such a divergence in subsistence patterns may reflect an inherent adaptability of Clovis technology to changing environmental conditions encountered as early populations spread southeastward into Texas (Ferring and Yates 1997).

\section{Archaic Period}

The Archaic period extends from ca. 6500 B.C. to A.D. 700 , with ca. 2,500-year segments often considered as early, middle and late divisions of the period (Prikryl 1993:199). Diagnostic artifacts for the period are similar to those of adjacent regions, although developing a sound chronological sequence of diagnostic artifacts has proven difficult because many of the investigations have focused on surface manifestations. Prikryl (1990) suggests that Early Archaic projectile points include early split-stemmed varieties and possibly Angostura, and Middle Archaic points include basal-notched forms such as Andice, Bell, and Calf Creek along with Bulverde, Carrollton, Dawson, and Wells. Late Archaic point types reportedly include Castroville, Dallas, Edgewood, Elam, Ellis, Gary, Marshall, Palmillas, Trinity, and Yarbrough (Prikryl 1990). At one time, the Carrollton and Elam foci were defined to refer to the Middle and Late Archaic respectively (Crook and Harris 1952, 1954). But reevaluation of the typesite artifacts showed that the materials were mixed such that perpetuation of these foci provides little interpretive value (Hofman et al. 1989:57; Prikryl 1990:73-74). Some of this mixing and the generally low numbers of Early and Middle Archaic sites may be because of exten- sive erosion of mid-Holocene deposits. This type of erosion has been documented for the Brazos drainage immediately west of the Fort Worth District in Young, Stephens, and Throckmorton Counties (Ensor et al. 1992:303).

Though few isolable components have been analyzed for the various divisions of the Archaic period in north-central Texas, slowly increasing populations responding to warmer and drier environmental conditions have been postulated to explain the overall archeological record of the period (Lynott 1981:103-104; Story 1990:212). It is thought that these factors may have led Archaic populations of the Cross Timbers and prairie areas of north-central Texas to develop a diversified hunting and gathering pattern based on bottomland resources of the rivers and major creeks, while populations on the Rolling Plains maintained a focus on bison hunting (Hofman et al. 1989:57-58). Projectile points of the period were fashioned from local lithic materials suggesting that populations were less mobile than their Paleoindian predecessors. Less mobility also may suggest refinement of the diversified subsistence pattern to include scheduling of resource use within morerestricted areas. Evidence from Late Archaic sites at Mountain Creek Lake (Peter and McGregor 1988) and Ray Roberts Reservoir (Ferring and Yates 1997) indicates repeated site occupation by small groups, which could support the resource scheduling hypothesis. Still, even with refinement of resource use, evidence of dietary stress has been found on Late Archaic human skeletal materials (Ferring and Yates 1997:305; Gill-King 1987:103-104).

Human burials are common in the archeological record of the Late Archaic and Late Prehistoric periods of at least the eastern part of north-central Texas (Prikryl 1993). Some of these burials are associated with Wylie pit features, which are large man-made depressions measuring ca. $16 \mathrm{~m}$ in diameter and $2-4 \mathrm{~m}$ in depth. These features were first identified at a series of sites along the East Fork of the Trinity River and were considered an important trait of the Wylie focus (Harris and Suhm 1963; Stephenson 1952; Wilson 1946). Radiocarbon assays from pits at the Upper Rockwall and Sister Grove Creek sites in the area of Lavon Lake suggest that the pits and the Wylie focus were associated with the Late Prehistoric period (Lynott 1975:117; Ross 1966). Lynott (1977) 
widened the temporal span by incorporating a Late Archaic phase into the focus definition. Subsequent work on Wylie pits at RichlandChambers Reservoir to the south confirmed their Late Archaic age (Bruseth and Martin 1987:165). But the wide range of artifact types associated with them and the long span of time represented made it clear that the Wylie focus was not a useful construct. Bruseth and Martin (1987:280-284), although discarding the focus as unusable, further supported Lynott's (1975) original interpretation of the pits as being associated with large-scale food processing. Their interpretation likens the pits to the burned rock middens of central Texas, with both representing group aggregations.

\section{Late Prehistoric Period}

Group aggregation and large-scale manipulation of subsistence resources, as represented by the Wylie pits and the human burials they contain, may indicate societal changes that continued through the Late Prehistoric period. Habitation structures indicating increased sedentism, at least in certain places and at certain times, have been found in some Late Prehistoric sites, along with cultigens such as corn and arrow points and ceramics indicating important technological changes. Also, there may be evidence of differential mortuary practices that could reflect a shift toward a hierarchical social structure (e.g., the distinction between burials placed inside and outside Wylie pits), although this evidence is nowhere near as strong as that for the Caddoan area of northeast Texas. Prikryl (1990, 1993) defines two chronological periods for the Late Prehistoric in northcentral Texas, which he links to particular projectile point and ceramic types.

Prikryl's $(1990,1993)$ Late Prehistoric I period (A.D. 700-1200) is marked by the arrow point types Alba, Bonham, Catahoula, Scallorn, and Steiner. Ceramic vessels are mostly grog tempered and undecorated, but there is some evidence of influences from other regions because some locally manufactured wares display designs similar to those associated with east Texas Caddo ceramic types. Evidence for corn and structures has been found at sites at Mountain Creek Lake southwest of Dallas, as well as to the north in Cooke County at Hubert Moss Lake near the Red River (Lorrain 1969; Martin
1994; Peter and McGregor 1988). Farther west, cultural changes also were taking place on the Rolling Plains, though this area held onto its Archaic lifestyle even after technological innovations such as the bow and arrow were accepted (Lynott 1981:106).

During the Late Prehistoric II period (A.D. 1200-1700), influences from the southern Plains became pronounced in the Cross Timbers and prairie areas. These influences coincided with an increase in bison herd size in northcentral Texas (Lynott 1981:106; Prikryl 1990:80). Bison were important to subsistence (Harris and Harris 1970; Morris and Morris 1970), but shrinking procurement territory sizes because of population increases continued the trend toward horticulture and settled village life. In terms of technology, a Plains Indian tool assemblage was common (Prikryl 1990:80). Items associated with this assemblage include calcareous-tempered ceramic vessels, some of which fit the description for the type Nocona Plain (shell tempered), and unstemmed triangular arrow points such as Fresno, Harrell, Maud, and Washita, as well as Perdiz points. Tools specific to bison processing include snubnosed or thumbnail scrapers and edge-beveled Harahey knives. Bison scapula hoes, which also are common in Plains Indian sites, have been recovered from sites in the Lewisville Lake and Lavon Lake areas of Denton and Collin Counties (Barber 1969:118-119; Harris 1945).

The Plains Indian influences associated with settled village life were used to define the Henrietta complex of north-central Texas. This complex, based on Krieger's (1946) moreexpansive Henrietta focus, extends from the Red River south along the headwaters of the Trinity and Brazos Rivers. The type site, M. D. Harrell, is situated along the Brazos River in Young County just northwest of Palo Pinto County in the drainage basin for Possum Kingdom Reservoir (Krieger 1946). The Harrell site and other associated sites contain middens, house structures, rock hearths, storage pits, and burials, and they most often are found on sandy knolls or terraces overlooking river valleys (Brooks 1989:85-86; Forrester 1994:249-266). Excavated sites attributed to the Henrietta complex include the Coyote and Glass sites on the Red River in Montague County (Lorrain 1967:2444; Woodall 1967a), and it is clear that sites such 
as Dillard in Cooke County are related as well (Martin 1994).

The Henrietta complex as an investigative tool can be limiting because its loose definition tends to obscure local differences. More-recent investigations in the upper Trinity River drainage have tended to highlight the local differences. For instance, at Ray Roberts Reservoir Ferring and Yates (1997:305) see local trends emerging independent of extraregional influences. They cite the lack of evidence for extensive maize horticulture and the preponderance of short-term logistical camps as the basis of their hypothesis. Similarly, Peter and McGregor (1988:367) demonstrated that occupation of the Mountain Creek drainage was less intensive in the Late Prehistoric II period than before and that maize horticulture, if practiced at all, was limited. Yet sites in both of these parts of the Trinity drainage have produced items characteristic of Plains Indian sites, such as shelltempered ceramics and diagnostic lithic tools.

\section{Historic Period}

By the eighteenth century, immigrant Plains Indian groups had moved into and beyond northcentral Texas, and their documentation by traders and explorers marks the start of the historic period. Documentary sources suggest that the Apache, Caddo, Comanche, Delaware, Kickapoo, Kitsai, Tonkawa, Wichita, and Yojaune traversed the region at various times during the period (Campbell 1983; Newcomb 1961; Newcomb and Campbell 1982). But archeological sites that can be associated definitely with historic groups are few. The Wichita are known to have moved into Texas from Oklahoma and Kansas in the early 1700 s. Sites attributable to the historic Witchita have been identified at the edges of north-central Texas. Among these are the Stansbury site in Hill County, now inundated by Lake Whitney (Stephenson 1970). Excavations at the site produced burials, house structures, storage pits, and a variety of aboriginal artifacts, along with European ceramics, glass beads, metal arrow points, and flintlock musket parts. A cluster of Wichita sites also occurs to the north along the Red River in Montague County. These sites are known collectively as Spanish For and occur on both the Oklahoma and Texas sides of the river. Woodall (1967b) excavated one of these sites, named the Upper Tucker site, which produced artifacts and features similar to those discovered at the Stansbury site. Wichita sites both on the Brazos and Red Rivers were situated atop high terraces that overlook the rivers.

\section{Central Rolling Plains}

\section{Previous Research}

The central Rolling Plains region includes the 13 counties in TxDOT's Abilene District plus the two northernmost counties (Stephens and Eastland) in the Brownwood District. The Rolling Plains, also known as the Lower Plains, Redbed Plains, or Rolling Mesquite Plains, is one of the least-defined archeological regions in Texas (T. Brown et al. 1982; Wulfkuhle 1986). Thoroughly investigated sites are few within the study area, and many lack reliable dates. As a result, the prehistoric chronology for the central Rolling Plains relies almost entirely on diagnostic artifacts recovered during surveys and the cultural chronologies from surrounding regions.

Although most of the central Rolling Plains study area is characterized by erosion-exposed redbeds (Triassic and Permian deposits), two prominent physiographic features are noteworthy. The two westernmost counties, Borden and Howard, extend up onto the High Plains and encompass portions of the Caprock Escarpment and the Llano Estacado flatlands underlain by the Ogallala Formation. The other feature is a series of extensive limestone plateaus-essentially erosional remnants of the greater Edwards Plateau - that run in a band just south of Interstate Highway 20 from west to east across Howard, Mitchell, Nolan, Taylor, Callahan, and Eastland Counties. These plateaus collectively are called the Callahan Divide, and they rise as much as $250 \mathrm{~m}$ above the surrounding landscape and constitute the drainage divide between the Brazos and Colorado Rivers. Thus, although most of the study area can be characterized as archeologically homogenous, the cultural remains associated with the Llano Estacado and Callahan Divide are distinctive from those of the Rolling Plains. Perhaps most significant, the Cretaceous limestones of the Callahan Divide constitute the northernmost exposures of Edwards Group formations in Texas and are rich in high-quality cherts (Frederick and Ringstaff 1994). Primary chert outcrops are encountered 
on and around the margins of the divide, and secondary gravel deposits (upland lag and stream channel gravels) are found for some distance all around the isolated Cretaceous plateaus.

Not only does the Callahan Divide represent the northermost Cretaceous limestone outcrops in Texas, but the divide also constitutes the northernmost occurrence of classic burned rock middens in the state. Creel's (1986:Figure 6) dissertation shows that burned rock middens are found in Jones, Taylor, and Callahan Counties, and subsequent researchers have located additional middens (e.g., Katz and Katz 2002). There are different theories as to how and why limestone rocks were used in cooking processes that resulted in the formation of middens, but there is little doubt that many of the archeological sites in the Callahan Divide area, especially the burned rock middens, were closely tied to central Texas during some cultural periods.

Some of the earliest archeological work in the state was done in and around Abilene by Cyrus N. Ray, a trained osteopath and avocational archeologist who also was one of the founders of the Texas Archeological Society in 1928. His primary interest was in the antiquity of humans in North America. Specifically, Ray (1934:107) sought evidence for "...Pleistocene man in Texas, if any such existed." Ray, along with E. B. Sayles and Dr. Otto Watts, began conducting surveys along the Clear Fork of the Brazos River and Big Elm Creek (Wulfkuhle 1986), ultimately documenting sites scattered over 12 counties. Ray thought that many of the sites he investigated were ancient because cultural remains were deeply buried in alluvial terraces. He was correct in a few cases but was incorrect more often than not. Without the aid of radiocarbon dating to accurately date the deposits, neither Ray nor his contemporaries realized the complex and dynamic nature of the river systems in the Rolling Plains or understood the significance of paleoclimatic changes on the archeological record.

Beyond his early man studies, Ray defined several cultural groups from later times, but most of these designations have long since been discarded or modified. Wulfkuhle (1986:Figure 16) and Creel (1990:13-22) provide good summaries of the various cultural classification schemes that have been applied to the central Rolling Plains.
A few large area surveys have been completed within or close to the study area (see Boyd 1997:Table 6 and Figure 13). These include Boyd et al. (1989), Brown and Anthony (1992), Cliff et al. (1991), Etchieson et. al. (1979), Jelks (1952), Lintz et al. (1991), Lynott (1979), Saunders et. al. (1992), Shafer (1971), Staley and Evaskovich (1993), Thurmond et. al. (1981), Tunnell (1960), and Wulfkuhle (1986). More-intensive investigations, especially large-scale excavations, have been rather limited. In general, the archeological data for the central Rolling Plains are insufficient to support detailed temporal, spatial, and functional comparisons of sites for various prehistoric time periods. With some exceptions, much of the cultural chronology sequence for the central Rolling Plains must be extrapolated from other nearby areas, specifically the PanhandlePlains region, central Texas, or north-central Texas. For this discussion, a blend of the cultural chronologies proposed for central Texas by Collins (1995:Table 2) and the Caprock Canyonlands by Boyd (1997:Figure 26) is used: Paleoindian (11,500 to 8800 B.P.); Early Archaic (8800 to 6000 B.P.); Middle Archaic (6000 to 4000 B.P.); Late Archaic (4000 to 1500 B.P., or 2000 B.C. to A.D. 500); Late Prehistoric I (A.D. 500 to 1100 or 1200); Late Prehistoric II (A.D. 1100 or 1200 to 1541); Protohistoric (A.D. 1541 to 1750); and Historic (A.D. 1750 to 1875).

\section{Paleoindian Period}

Paleoindian artifacts in the central Rolling Plains are generally surface finds in isolated contexts. Identified point types include Clovis, Folsom, Plainview, Scottsbluff, and Angostura (Meltzer 1986; Meltzer and Bever 1995; Prewitt 1995; Suhm 1958). The bulk of the information available for the Paleoindian period is based on documented surface collections and surveys conducted from the first half of the twentieth century, like those of Ray $(1929,1934,1938,1940)$. He correctly recognized some deeply buried sediments, which he named the "Durst soils," as being ancient deposits (Ray 1930:45-46; Ray and Bryan 1938; Sellards 1952:36; Suhm et. al. 1954:99).

Based on the scarcity of sites and the presence of nonlocal materials, some researchers have concluded that Paleoindian groups were highly mobile with low-density populations (Hoffman 1989:25). The environment during the 
Paleoindian period was most likely much wetter and cooler than today (Collins 1995; Holliday 1997; Wendorf and Hester 1975). In terms of subsistence strategies, researchers have long thought that Paleoindians relied primarily on big-game hunting, a rather specialized lifestyle evidenced by killing and butchering tools found in association with extinct forms of bison (Hoffman 1989:25). Although kill sites are common for this period, small seasonal campsites and secondary processing sites also are known (Harrison and Killen 1978:87; Johnson 1977) but are more difficult to identify. Recent finds are challenging the strict notion of nomadic biggame hunters and suggest Paleoindians had a broader hunting-gathering strategy (Collins 1995:381-383; Collins et al. 1989).

Several Paleoindian sites are reported in the study area, but even the most significant sites are known only through excavations more than 30 years ago. The Lone Wolf site near Colorado City (Mitchell County) is not a particularly famous site, but the 1925 finding of distinctive lanceolate projectile points (now typed as Milnesand and Plainview or Firstview) in association with extinct bison at this locality predated the now-famous investigations at the Folsom site that began in 1926 (Holliday 1997:161, 166; Wormington 1957:110).

The Office of the State Archeologist conducted excavations at the Adair-Steadman site (41FS2) in Fisher county in the 1970s. It is a Folsom campsite situated on a high terrace above the Clear Fork of the Brazos. The work has yet to be reported, but Tunnell (1975) examined the stone artifacts and reported on the lithic technology associated with Folsom point production using local Edwards cherts. Much of the site remains intact, and it is listed on the National Register of Historic Places and designated as a State Archeological Landmark.

Mallouf (1989) reported on investigations at the Yellow Hawk site, a Clovis lithic workshop on the Callahan Divide. This Taylor County site contains rare evidence of a discrete Clovis point production episode at an upland chert locality in a nondepositional setting. The time of this event could not be established through independent dating.

Other significant Paleoindian sites in the study area that have been investigated, albeit minimally, include the McLean site (Wulfkuhle 1986:66) in Taylor County, Gibson site (Ray
1940) in Shackelford County, and the Biedleman Ranch site in Stonewall County (Wulfkuhle 1986:69).

\section{Archaic Period}

As originally defined, the Archaic period spans many thousands of years, from 8800 to 1500 B.P. Compared with the preceding Paleoindian period, Archaic life was significantly different, reflecting a long period of relative cultural stability (Collins 1995:383). Subsistence patterns appear to have been more diverse, with evidence for greater exploitation of local environments (Hofman et. al. 1989:45). There is evidence for an increase in the dietary importance of smaller game animals, fish, and wild plant foods (Cliff et. al. 1991:15). A hunting and gathering lifestyle prevailed, with seasonal travelling to use different food resources in various localities but a marked decrease in group mobility (Hofman et al. 1989:58; Weir 1976).

The Rolling Plains Archaic often has been divided into Early, Middle, and Late subperiods (e.g., Etchieson, Speer, and Hughes 1979; Kelley 1947a; Prewitt 1981, 1985; Story 1985a; Suhm, Krieger, and Jelks 1954; Weir 1976). Distinctions between these periods are based in large part on changes in projectile point styles, but the transitions between periods may well coincide with climatic shifts (Boyd 1997:226-231; Collins 1995:Tables 1 and 2). Collins (1995:383) notes for central Texas that there were distinctive cultural changes within the broad Archaic tradition, but that the nature and timing of those shifts are poorly understood. It is clear, however, that the appearance and proliferation of burned rock middens in Archaic times (Collins 1995:384) is one of the most significant prehistoric cultural events in this part of Texas.

The Early Archaic period (8800 to 6000 B.P.) is not well represented in the Rolling Plains, and most of the finds come from mixed contexts. Some archeologists have suggested a transitional stage between the Paleoindian and Archaic cultures that exhibits similarities to both periods (Hoffman et. al. 1989; McKinney 1981; Sollberger and Hester 1972). The transition from late Paleoindian to Early Archaic was a time of considerable environmental change, with a cooler, wetter climate giving way to much warmer, dryer conditions (Collins 1995). In fact, 
most paleoenvironmental evidence suggests that a major period of aridity, originally called the Altithermal period by Antevs (1955), occurred over central Texas in early to middle Holocene times from about 8000 to 4000 B.P. (Collins 1995:Table 2; 378-380). In the central Rolling Plains, the Early Archaic is seen as a period of increasing aridity that led to full-blown drought conditions during the Middle Archaic. Over much of Texas, these climatic conditions had profound effects on human populations and on the cultural remains that survive, or failed to survive, in the archeological record.

In the study area, representative Early Archaic dart points include stemmed, cornernotched with expanding stems, triangular, and heavily barbed forms, including Angostura, Gower, Martindale, Uvalde, and Wells (Collins 1995:Table 2; Turner and Hester 1999). In addition, Clear Fork gouges, burins, circular scrapers, a variety of bifaces, and grinding implements are also present. Only a small number of sites dating to the Early Archaic have been reported for the central Rolling Plains Region, and no major excavations associated with this period have been reported. The relative paucity of sites from this time period appears to be a result of a severe erosional episode (or episodes) in the Southern Plains during Middle Archaic times. Widespread erosional scouring is thought to have removed significant amounts of early Holocene deposits and Early Archaic archeological remains (Boyd 1997:226-231). Given the limited information available for this time period, it is difficult to elucidate human adaptive strategies and lifeways. But data from central Texas suggests diffuse economic systems with people exploiting an array of resources and alternating between various subsistence activities (Story 1985a:39). It is safe to say that the overall hunter and gatherer population density was low during this period.

The Middle Archaic, from 6000 to 4000 B.P., is poorly represented in the study area but may include Ray's (1945) Clear Fork complex originally assigned to the Paleoindian-Archaic transition (Cliff et. al 1991:15). In the central Texas archeological record, there appears to have been a population increase during the Middle Archaic and development of regionally distinct cultural patterns along with changes in settlement patterns, economic and social systems, and technology (Collins 1995:384). If these changes occurred in the Rolling Plains, evidence is extremely limited because of geomorphic reasons. A considerable body of paleoclimatic evidence suggests that extremely xeric conditions (i.e., the latter half of the Altithermal) and erosional scouring were prevalent in the Southern Plains from ca. 6500 to 4600 B.P. (Boyd 1997:226-228: Hughes 1991:19-20). With a combination of low human population density because of droughts and concurrent erosional scouring, it is not surprising that Middle Archaic archeological sites are rare.

Although human populations may have been increasing in central Texas during the Middle Archaic, there appears to have been minimal human activity on the Llano Estacado and Rolling Plains (Boyd 1997:52; Hughes 1991:20). In the central Rolling Plains, Middle Archaic sites are usually represented by surface scatters, and no substantive investigations of buried components have been made. Collins (1995:Table 2) lists Andice, Bell, Taylor, Nolan, and Travis points as definitive Middle Archaic points in central Texas, but these types are rare in the central Rolling Plains. Prewitt (1995) shows only a few Nolan points occurring within the study area.

In central Texas, burned rock middens became common during the Middle and Late Archaic periods (Black et al. 1997:273-280; Collins 1995:384). The ages of many of the burned rock middens known in Callahan, Jones, Mitchell, Shackelford, and Taylor Counties are unknown (Creel 1986; Mauldin and Nickels 2003), but some of them may well be Middle to Late Archaic in age.

The Late Archaic saw the development of an array of new cultural patterns and a proliferation of projectile point styles (Collins 1995:Table 1; Story 1985a:45). Subsistence patterns in the central Rolling Plains changed as people became more reliant on bison hunting, with herds becoming more common after long periods of bison absence or scarcity during part of the Early Archaic and all of the Middle Archaic (Dillehay 1974). The Late Archaic period in the study area is most commonly represented by open campsites and isolated burials, but bison kill and processing sites are common farther north in the Rolling Plains (Boyd 1997:Table 59, Figure 78).

Sites in the study area contain a variety of Late Archaic dart point styles-Castroville, 
Darl, Edgewood, Elam, Ensor, Fairland, Frio, Marcos, Marshall, Nolan-that are often associated with central Texas (Boyd 1997:Table 60; Collins 1995:Figure 1), along with some styles common in north-central Texas such as Eliasville, Ellis, and Godley (Cliff et. al. 1991:16). Late Archaic components investigated at Lake Alan Henry in Kent and Garza Counties produced Castroville, Marcos, and Marshall dart points (Boyd 1997:249-250). Mack (1994) reports on an intensive surface collection of the Van York site (41BD8) in Borden County that yielded Edgewood and Ellis points. In the 1980s the Texas Department of Highways and Public Transportation conducted a limited testing project at 41KT32 on the floodplain of the Brazos River in Kent County. Small expanding-stem dart points indicated Late Archaic occupations (Denton 1983).

Late Archaic burials from Kent (Holden 1929) and Mitchell (Ray 1936) Counties contain unusual lunate stones made of exotic rocks as grave offerings. The Mitchell County find was a cremated burial that had Fairland, Marcos, and Shumla points associated with it. The cultural significance of lunate stones and cremation as mortuary traits are not fully understood (Boyd 1997:253-257).

\section{Late Prehistoric Period}

The Late Prehistoric period (1200-450 B.P.) was a time of rapid and significant changes among prehistoric cultures. Technological changes, including emergence of the bow and arrow, use of ceramics, and adoption of horticulture occurred at different times in different locations and should be viewed as a process rather than an event. For whatever reasons, people in some regions adopted the bow and arrow later than others, and some people never adopted agriculture, but others did. In the study area, some Late Prehistoric sites and assemblages continue to show similarities to central Texas, but there were distinctive cultural influences in the Rolling Plains that are not evident in central Texas. Across much of central Texas, there is evidence of increasing relationships with Caddoan peoples to the east, but the Rolling Plains region also has stronger evidence of influences from Plains Woodland and Plains Village peoples to the north and Puebloan peoples to the west, as well as limited Caddoan influence (Boyd 1997:491-496; Cliff et. al. 1991:16).

In Late Prehistoric I times, which lasted from about A.D. 500 to 1100 or 1200 , two cultural complexes are recognized in the study area. There were probably more than two groups within the central Rolling Plains at this time, but only the Palo Duro and Blow Out Mountain complexes are recognized as definable archeological entities.

The core area of the Palo Duro complex is situated along the Caprock Escarpment and mainly to the north of the study area (Boyd 1997:Figure 84), but the southern end of the culture area extends into the Rolling Plains. At least two sites in the study area-the Big Spring site in Howard County and the South Sage Creek site in Kent County-are attributed to the Palo Duro complex (Boyd 1997:Figure 85 and Table 66). One of the most significant sites of the Palo Duro complex is the Sam Wahl site (41GR292) in Garza County, immediately west of the study area. The discovery of a circular pithouse, large subterranean storage pits, and baking pits there led to a comparative study and redefinition of the Palo Duro complex (Boyd 1995, 1997). The complex is considered to represent foraging peoples who primarily occupied the canyonlands along the Caprock Escarpment but also ventured onto the High Plains and Rolling Plains, probably seasonally. Deadman's arrow points are the distinctive style for the complex, but Scallorn and stemmed Alba or Alba-like arrow points also are found. These people do not appear to have made any pottery, but they imported plain brownware pots from the Jornada Mogollon region to the west. Bison were of little importance, presumably because they were so scarce from around A.D. 500 to 1000 , but hunting deer and smaller animals was important. Paleoclimatic evidence suggests cooler and wetter conditions during this time, and Palo Duro peoples harvested a range of wild plant foods, including mesquite beans and shin oak acorns. They used a variety of grinding tools and baking pits to process these and other plants. Although no cultigen remains have been found at any Palo Duro complex sites, the possibility that the people practiced limited horticulture cannot be ruled out.

The recent finding of corn at the Bear Branch site (41CA13) in Callahan County sheds new light on agriculture in the Callahan Divide 
area. A charred corn kernal (Zea mays) was recovered from a cooking pit associated with a burned rock midden (Katz and Katz 2002), and a bulk sediment radiocarbon date of A.D. 1160 to 1290 (calibrated, two-sigma) is associated. To the authors' knowledge, this is the only documented occurrence of prehistoric corn in the Rolling Plains region and the westernmost reported occurrence in northern Texas, excluding the Panhandle (see Henrietta complex below). The cultural affiliation of this site is not certain. Katz and Katz (2002) suggest the Bear Branch site belongs to the Blow Out Mountain complex (see below), but the cultural affiliation is complicated by a fairly long span of occupation (estimated to be from A.D. 600 to 1600) and a variety of diagnostic points. Along with a few dart points, the Bear Branch assemblage includes early-style arrow points such as Scallorn and Alba and late-style arrow points such as Fresno, Perdiz, and Washita. The site definitely has multiple use episodes, and it could represent occupations by different groups over time or perhaps contemporaneous use by multiple groups. Some of the occupations could be associated with the Henrietta or Palo Duro complexes. The Scallorn and Alba points in particular suggest an affiliation with the late Palo Duro complex, despite the absence of imported Mogollon brownware pottery. Regardless of who the occupants were around A.D. 1200, the corn likely indicates that people were farming at or close to the Bear Branch site during the transition time from Late Prehistoric I to II.

Creel (1990:15-18) defined the Blow Out Mountain complex based on his work at the East Levee site, and this culture area encompasses much of the central Rolling Plains (see Boyd 1997:280-281). The complex is transitional between Late Prehistoric I and II and presumably dates from about A.D. 800 to 1300. As it is currently defined, the Blow Out Mountain complex subsumes Cyrus Ray's (1929) Sand Dune Culture and Sayles and Ray's Brazos River Culture (Sayles 1935; see Ray and Sayles 1941). Blow Out Mountain also includes many cairn burial sites and "rock-covered mounds" excavated in the study area during the 1930s and 1940s. Evidence in many of these graves suggests that intercultural violence was prevalent in the Rolling Plains during Late Prehistoric times (see Boyd 1997:280-281, 491-496; Brooks 1994).

The Blow Out Mountain strata at the East
Levee site, in contrast to the Late Archaic strata below and the Toyah phase strata above, contained no bison remains. The stone-lined hearths, faunal remains, and stone tool assemblage all indicate generalized hunter-gatherers. No ceramics are associated with the complex. Typical arrow points fall into one of four categories: stemmed points often typed as Alba or Bonham; Chadbourne points (Turner and Hester 1999:207) that appear to be smaller versions of Darl or Zepher dart points; contractingstem Cliffton-like points; and side-notched Washita points). Of particular note, many of the Alba-like points are longer and have serrated blades, and this form is most commonly associated with human burials. These were named Moran points by Forrester (1987), and many specimens found in burials appear to be arrow tips that caused death (Boyd 1997:280-281).

There are some interpretive problems with the Blow Out Mountain complex because of the limited sample of excavated components and the lack of chronological control. It may be that Blow Out Mountain represents a single culture undergoing rapid changes during a critical time from A.D. 800 to 1300 . Or, it may be that the complex needs to be split into two or more cultural groups as more data come to light.

The transition from the Late Prehistoric I to Late Prehistoric II periods, occurring sometime around A.D. 1100 to 1200 , was a time of significant cultural changes across the American Southwest and Southern Plains. In the Southern Plains, it is generally linked with a shift from cooler, wetter conditions to a warmer, dryer climate. These dryer conditions are presumed to have been more favorable for grasslands and bison. It is at about this time that bison populations seem to have exploded in the Southern Plains, and most cultures shifted subsistence strategies to intensify bison hunting pursuits (Dillehay 1974). Many cultures also intensified their agricultural pursuits at this time, apparently shifting from simple horticultural practices to more substantial farming primarily involving corn (Brooks 1989; Hoffman et al. 1989). The extent to which this Plains Woodland to Plains Village transition occurred, or did not occur, in the central Rolling Plains is uncertain because of the lack of substantive archeological excavations.

During the Late Prehistoric II period, local cultures may have modified their subsistence 
base to incorporate or intensify bison hunting while other groups moved into the Southern Plains from surrounding areas to exploit the expanded bison range. But some climatic fluctuations within the Late Prehistoric II period may have been significant, and there is evidence of two major drought periods in the Southern Plains that were extremely long and severe: one around A.D. 1275 to 1300 and another around A.D. 1550 to 1600 (Woodhouse and Overpeck 1998). These periods certainly would have affected animal and human populations and may have served as catalysts for cultural changes.

At least three different cultural groups are thought to have inhabited part or all of the study area during the Late Prehistoric II period and into Protohistoric times. These groups were associated with the Garza complex, Henrietta complex, and Toyah phase. All three cultures seem to be present in the study area (see Boyd 1997:Figure 96), and the central Rolling Plains is within a "shared area" identified by Johnson (1994:Figure 105) as a place were several cultural groups lived and interacted. Because of the dynamic cultural nature of this shared area during Late Prehistoric II times, the archeological remains are diverse, intriguing, and confusing.

The Garza complex (Boyd 1997:495) is represented by bison kill and processing sites, shortterm hunting camps, rockshelters, and residential base camps with evidence of tipi-like dwellings. Isolated burials also are associated. Material culture includes a triad of bison hunting and skinning tools-the distinctive Garza and Lott points, Plains-style end scrapers, and beveled knives. Stone tool assemblages are strictly functional at most Garza sites, particularly those related to bison hunting and processing, and striated pottery sherds from plainware pots are often associated. In contrast, at residential bases where more intensive occupations occurred, a range of imported Puebloan items is usually found. Obsidian, turquoise, and Olivella shell beads are sometimes present, and decorated Puebloan pottery is abundant at some sites. Further evidence of Puebloan trade is found at seventeenth-century sites in the form of historic-age materials (e.g., majolica pottery, gunflints and lead, cow and horse bones) that were obtained from Spanish colonial settlement or mission pueblos like Pecos.

The Garza complex extends into the north- western counties of the study area, and the Longhorn and Headstream sites in Kent County (41KT53 and 41KT51) are two Garza complex sites that have been intensively investigated (Boyd 1997:380-381). Garza peoples were major players in the Southern Plains-Pueblo interaction during the middle to late 1600 s and appear to have processed large numbers of bison hides for the Pueblo trade. The intensity of Plains-Puebloan trading increased through time, and it is notable that prehistoric Garza sites (i.e., those before A.D. before1541) may look very different from protohistoric Garza sites dating after about 1650 .

Krieger (1946) defined the Henrietta complex based primarily on late 1930s excavations at the Harrell site (Hughes 1942) to the east of the study area in Young County. Most of the sites attributed to this complex are east of the central Rolling Plains study area (see the culture history section for North Central Texas), but the westernmost extent of this culture area appears to include Callahan, Eastland, Shackelford, and Stephens Counties. The Henrietta complex represents the southernmost Plains Village manifestation in Texas (Boyd 1997:360-361; Brooks 1989:85-86). It is characterized by small circular to oval houses (with walls lined with posts and having three or four interior posts), storage pits, a variety of arrow points (Fresno, Harrell, Scallorn, and Washita being most common; Alba, Bonham, Eddy, and Perdiz being less common), and Nocona Plain pottery tempered with limestone or shell. Henrietta peoples did some farming. Charred corn has been recovered from sites in Young and Cooke Counties, and bison scapula hoes were used as gardening tools. Henrietta peoples were tied into interregional exchange networks, with trade to the west and northwest as indicated by obsidian, Alibates flint, and Puebloan pottery, and trade to the east as indicated by celts and Caddoan pottery.

The Henrietta complex is somewhat confusing because of the low number of investigated sites and the lack of chronological control. It shows similarities to the Blow Out Mountain complex to the west and to the Sanders and Wylie phases to the east (Boyd 1997:361; Brooks 1989:85-86). One thing that is clear, however, is that there is a high frequency of violence in burials, and warfare seems to have been prevalent in this culture (Boyd 1997:360-361).

The Toyah phase was first proposed by 
Kelley (1947b) and later revised by Jelks (1962). More recently, Toyah culture was redefined by Johnson (1994) based on his work at the Buckhollow site in Kimbell County. He defined what he called a Classic Toyah culture area that extends northward up into the Rolling Plains region and to the southern edge of the study area. He also defines a shared culture area that encompasses the study area (Johnson 1994:Figure 105). Classic Toyah culture is identified by Perdiz arrow points, Plains-style end scrapers, beveled knives, and bone-tempered plainware pottery (often called Leon Plain).

Toyah phase artifacts are found outside the Classic Toyah area, particularly to the north and northwest, but they seem to be mixed with traits and materials from other cultures. Evidence that Toyah people ventured into the Rolling Plains includes Perdiz-associated bison-processing sites to the south of the study area (e.g., the Elm Creek site in Concho County and the Rush site in Tom Green County), but Perdiz arrow points are found as far north as the southern Llano Estacado (Boyd 1997:82). One particularly interesting find in the study area is the WeaverRamage cache in Kent County (Tunnell 1978), containing more than 800 items of high-quality Edwards chert, including a Perdiz point. It is thought to be a cache made by Toyah people. Within the shared area of the Rolling Plains, Perdiz points are found alongside other distinctive arrow point styles (such as Cliffton, Garza, Harrell, Lott, and Washita) and with a wide range of ceramic types. As noted with the Henrietta complex above, violence in Toyah phase burials indicates that the groups in the shared area were not always friendly toward each other (Boyd 1997:364; Prewitt 1981:83).

\section{Historic Period}

The Historic period begins with Coronado's entrada in A.D. 1541 and ends in 1875 . The cen- tral Rolling Plains study area was undoubtedly occupied at various times by Apaches, Jumanos, Comanches, and other Native American groups, but recognizing the archeological remains of these historic cultures is difficult at best.

When Coronado entered the northern part of Texas in 1541, he met two different groupsQuerechos and Teyas-and they were enemies (Boyd 2001). Most researchers agree that the Querechos were Apache peoples, and an Apache presence in the Southern Plains seems certain in the latter $1500 \mathrm{~s}$ and $1600 \mathrm{~s}$. There is less certainty as to the identity of the Teyas, but the most prominent theory is that they represent Jumano peoples described in Spanish accounts from the seventeenth and eighteenth centuries (Boyd 2001; Kenmotsu 2001). The Jumano culture area probably extended up into the Rolling Plains, but its precise boundaries are not well documented (Hickerson 1994:Map 6; Kenmotsu 2001:Figure 1). No sites in the study area are attributed to the historic Apache or Jumano.

The cultural dynamics in the Southern Plains changed radically once again between 1700 and 1725 when the Comanches suddenly appeared (Wallace and Hoebel 1986:6-8). To combat the Comanche threat, it appears that the Jumano and Apache may have become allies in the early 1700s (Kenmotsu 2001:33), but these and other groups were ultimately displaced by the more-powerful Comanche bands. They remained the dominant force in the Southern Plains until the 1870s, when the U.S. Army launched several campaigns and finally removed the Comanches and their allies from the region (Newcomb 1961:155-157). With two prominent Indian Wars, military posts in Shackelford County (Fort Phantom Hill) and Throckmorton County (Fort Griffin), and many important historic-age military roads, the central Rolling Plains region has the potential to contain historic-age Indian encampments, U.S. military sites, and Indian Wars battle sites. 



\section{SUMMARY OF IMPACT EVALUATIONS AND SURVEYS}

Ninety-seven work authorizations distributed across all seven districts were completed (Figure 4). These consisted of 94 Impact Evaluations, 74 Surveys, 14 Surveys with Geoarcheological Evaluation, and 1 work authorization to produce this report. Combined, these work authorizations entailed efforts at 128 bridge replacements, 40 road realignments or widening projects (many also involving bridge replacements), 5 new road construction projects, 4 hike-and-bike trail construction projects, 4 rest area construction projects, 3 projects involving upgrades to 9 existing bridges or culverts, 2 projects where new borrow pits are planned, 2 projects involving relocation of historic-age bridges to public parks, 1 project involving construction of 2 new bridges, 1 project involving replacement of an interstate highway interchange, and 1 project involving establishment of a wetland mitigation area. During completion of these work authorizations, 43 newly discovered or previously recorded archeological sites were investigated (although in the case of 14 previously recorded sites, no archeological remains were observed in the areas that will be affected by the proposed Transportation Activities).

This chapter begins with an outline of the methods used in accomplishing the work authorizations. Next, the work efforts are summarized in terms of distribution and setting, followed by a discussion of the existing disturbances observed as they relate to the potential for archeological remains in good context at these locations and descriptions of the sites investigated. The section closes with a discussion of the utility of the fieldwork done under these work authorizations.
3

\section{METHODS}

Each work authorization done under this contract began with acquisition of the appropriate USGS map(s), a file search at the Texas Archeological Research Laboratory or the online Texas Archeological Sites Atlas for known sites in and near the project area, and review of project plans to identify impact areas. The field methods employed varied depending on the type of project.

For Impact Evaluations, fieldwork typically consisted of on-the-ground examination of existing and proposed right of way on both sides of the road along the full length of the project area. Where right of entry had not been obtained for known or potential impact areas beyond the existing right of way, these areas were inspected visually across fence lines. The ground surface and any disturbed areas (e.g., road cuts, the backdirt of recently placed fiber optic or telephone lines, plowed fields, and so on) within and adjoining the existing right of way were examined for evidence of archeological remains. The primary thrust, however, was to record the kinds and extent of disturbance and determine the likelihood of archeological remains in undisturbed contexts. In most cases, this entailed examining visible stream cutbanks and overall landscape geometry to form an opinion about the thickness and extent of Holocene alluvium that could host buried archeological deposits. Typically, shovel tests were not dug because cutbanks provided adequate information on sediment thickness.

For each bridge replacement or other Transportation Activity, a standardized Impact Evaluation form was completed recording anticipated 


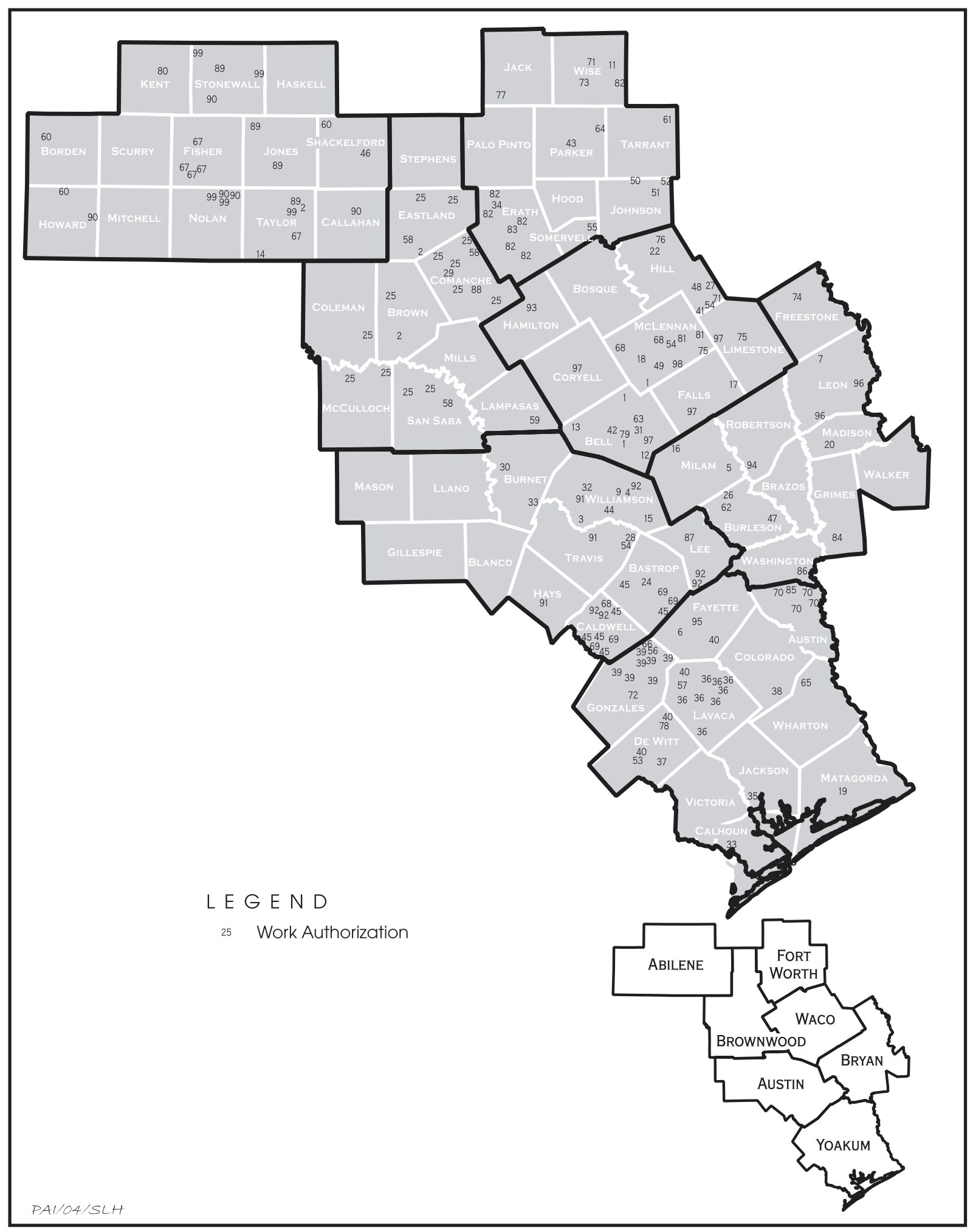

Figure 4. Map of the study area showing the locations of all Impact Evaluations and Surveys. 
impacts, location and extent of disturbances (e.g., ditches, fill sections, underground utilities, gullying and erosion, and other), location and extent of undisturbed right of way; surface visibility; subsurface exposures; geologicgeomorphic setting; nature, thickness, and origin of sediments; archeological remains observed; recommendations; land use; vegetation; personnel; and time spent. Each project area also was documented with color photographs. One or two people did Impact Evaluations, with the typical bridge replacement requiring 1-2 hours. Each of the Impact Evaluations that involved long stretches of highway was carried out as a series of on-the-ground inspections (i.e., at each stream crossing) following the methods outlined above, with the intervening upland areas generally subjected to windshield inspection.

For Surveys and Surveys with Geoarcheological Evaluations, fieldwork included excavating enough backhoe or Gradall trenches, or shovel tests, to constitute a good-faith effort toward determining whether archeological sites are present. As listed in Table 1, 392 trenches were excavated in 72 of the 87 survey areas, ranging from as few as 1 trench to as many as 36 . On 31 surveys, 172 shovel tests were dug in addition to trenches (range $=1-45$ tests). On 14 other surveys, only shovel tests $(\mathrm{n}=121)$ were dug because there are no deep Holocene deposits requiring trenching. In one project, survey consisted of stripping a $20 \times 5-\mathrm{m}$ area with a Gradall. In a single survey area, neither trenches nor shovel tests were needed for effective coverage because of good ground surface visibility and the lack of deep Holocene deposits. Ten of the surveys were restricted to existing rights of way; substantial parts of these survey areas (often half or more) were disturbed by existing roads and bridges. These 10 surveys involved excavating 33 trenches, 17 shovel tests, and 1 Gradall-stripped area. Sixty-nine surveys were in relatively undisturbed proposed new rights of way or construction or drainage easements varying from 0.1 to 31.0 acres in size ( median $=1.7$ acres; total $=330$ acres [acreage figures exclude 3 surveys done under Work Authorizations 33 and 99 in which the amounts of new right of way were unknown at the time of survey]). In surveying these areas, 333 trenches and 224 shovel tests were excavated. Four surveys were for proposed hike-and-bike trails to- taling $9.9 \mathrm{~km}$ in length; 12 trenches and 23 shovel tests were dug in these four areas, which had seen varying amounts of prior disturbance. Three surveys were in relatively large (54 acres total), relatively undisturbed areas that will be used as borrow pits or a wetland mitigation area; 8 trenches and 29 shovel tests were excavated in these areas. Finally, 2 surveys were in relatively undisturbed public parks where historicage bridges will be relocated; 6 trenches were excavated in these areas. Trenches and shovel tests usually were placed according to the size and shape of each survey area, distributions of landforms, accessibility, and the locations of known sites rather than at specific intervals.

The trenches were at least $5 \mathrm{~m}$ long and $0.75 \mathrm{~m}$ wide and were usually at least $1.5 \mathrm{~m}$ deep (i.e., the anticipated maximum depth of substantial disturbance). After excavation, their walls were cleaned and examined for cultural materials. Stratigraphic descriptions were prepared for selected trenches to characterize the sediments. Shovel tests averaged $30 \mathrm{~cm}$ in diameter and were dug to varying depths depending on depth to bedrock, clay content, and water content. The sediments removed from shovel tests were screened through 1/4-inch-mesh hardware cloth. A standardized Survey Summary Form was completed noting whether the survey included a geoarcheological evaluation; describing the areas subjected to surface survey; noting visibility; indicating the number, depth, and placement of shovel tests and trenches; listing the cultural materials observed and sites recorded; providing assessments and recommendations; and noting the personnel and time needed for the survey. Other documentation consisted of color photographs, Temporary Site Forms (for eventual submittal to the Texas Archeological Research Laboratory in TexSite format), stratigraphic profile descriptions, and project plans showing the locations of all trenches, shovel tests, and sites. Surveys usually were done by two-person crews; on Surveys with Geoarcheological Evaluations, one member of the crew was a geoarcheologist. The time required to complete the surveys varied depending on their size, the number of trenches and shovel tests excavated, and what was found. The range was 2-112 person-hours, with the median being 5.5 person-hours (excludes time spent by TxDOT personnel, including backhoe and Gradall operators). 
Archeological Impact Evaluations and Surveys

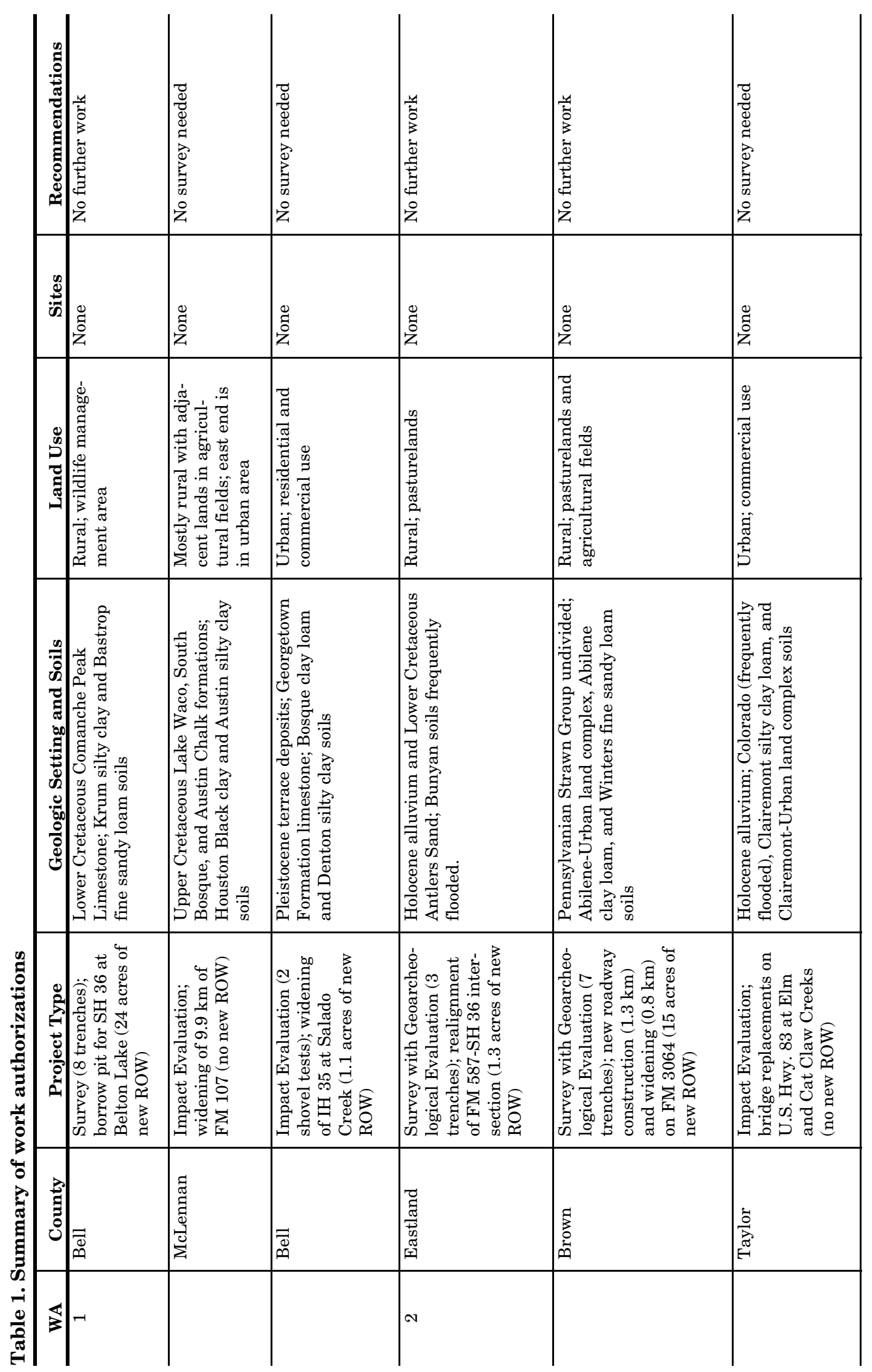


Chapter 3: Summary

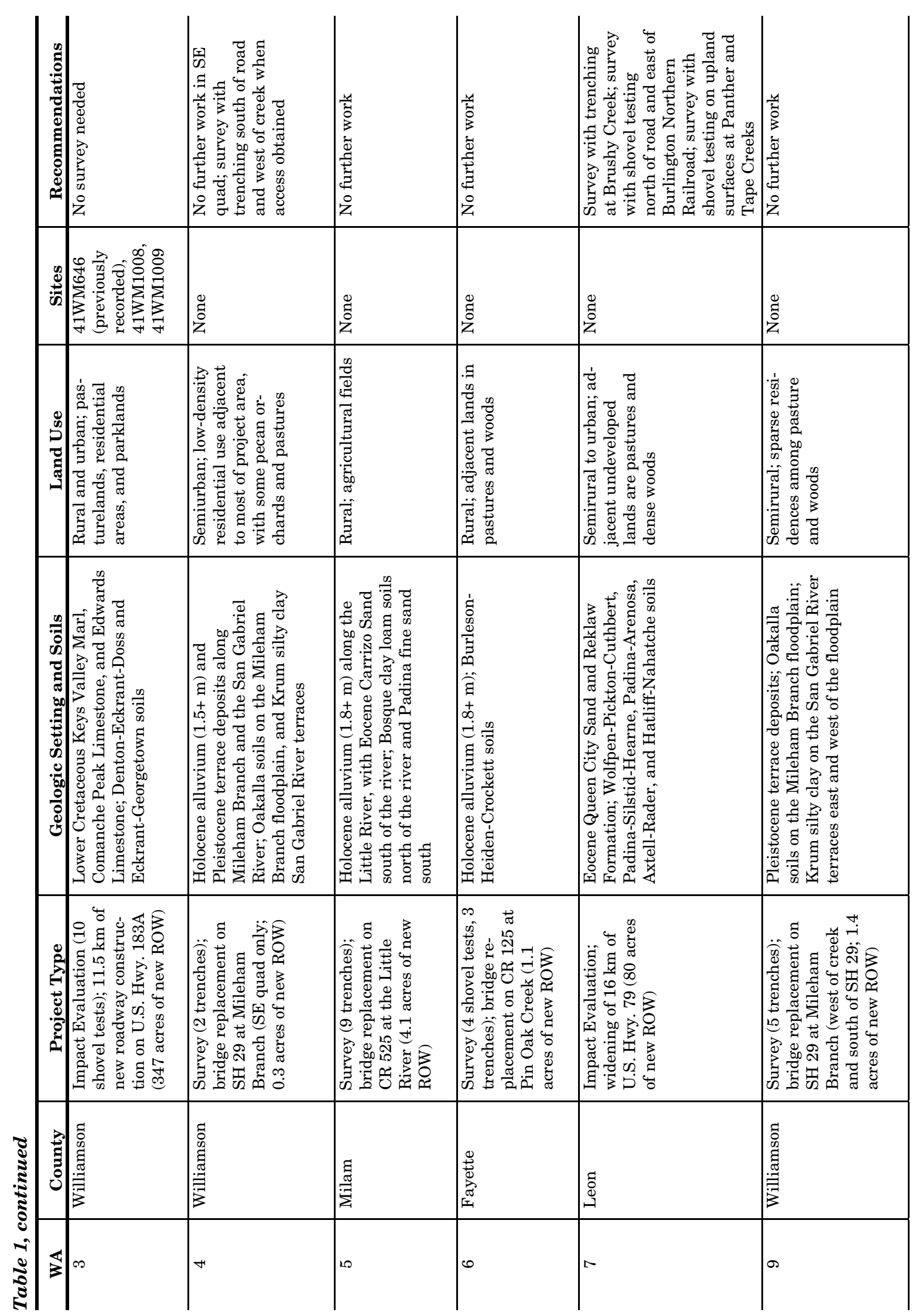


Archeological Impact Evaluations and Surveys

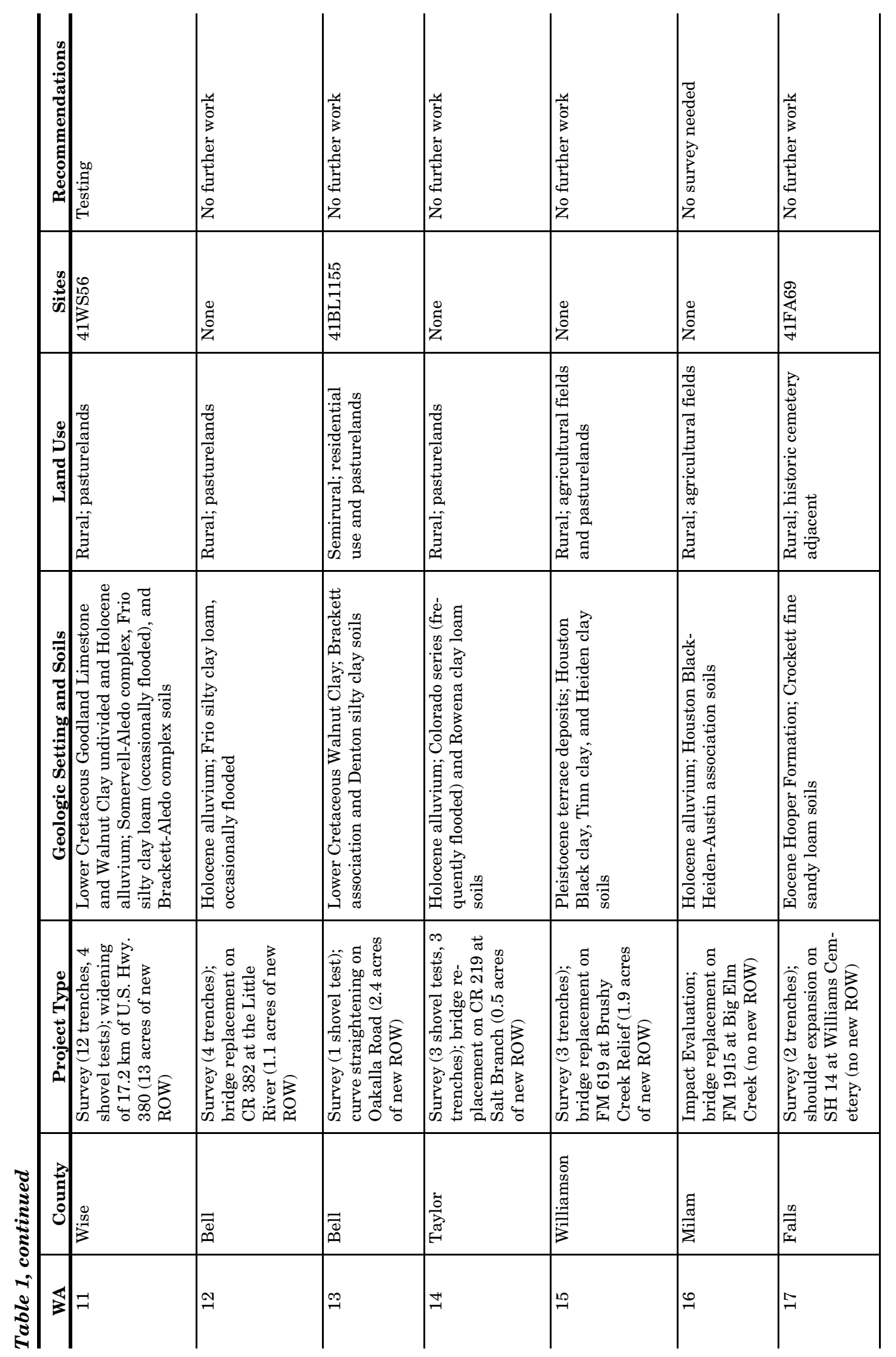


Chapter 3: Summary

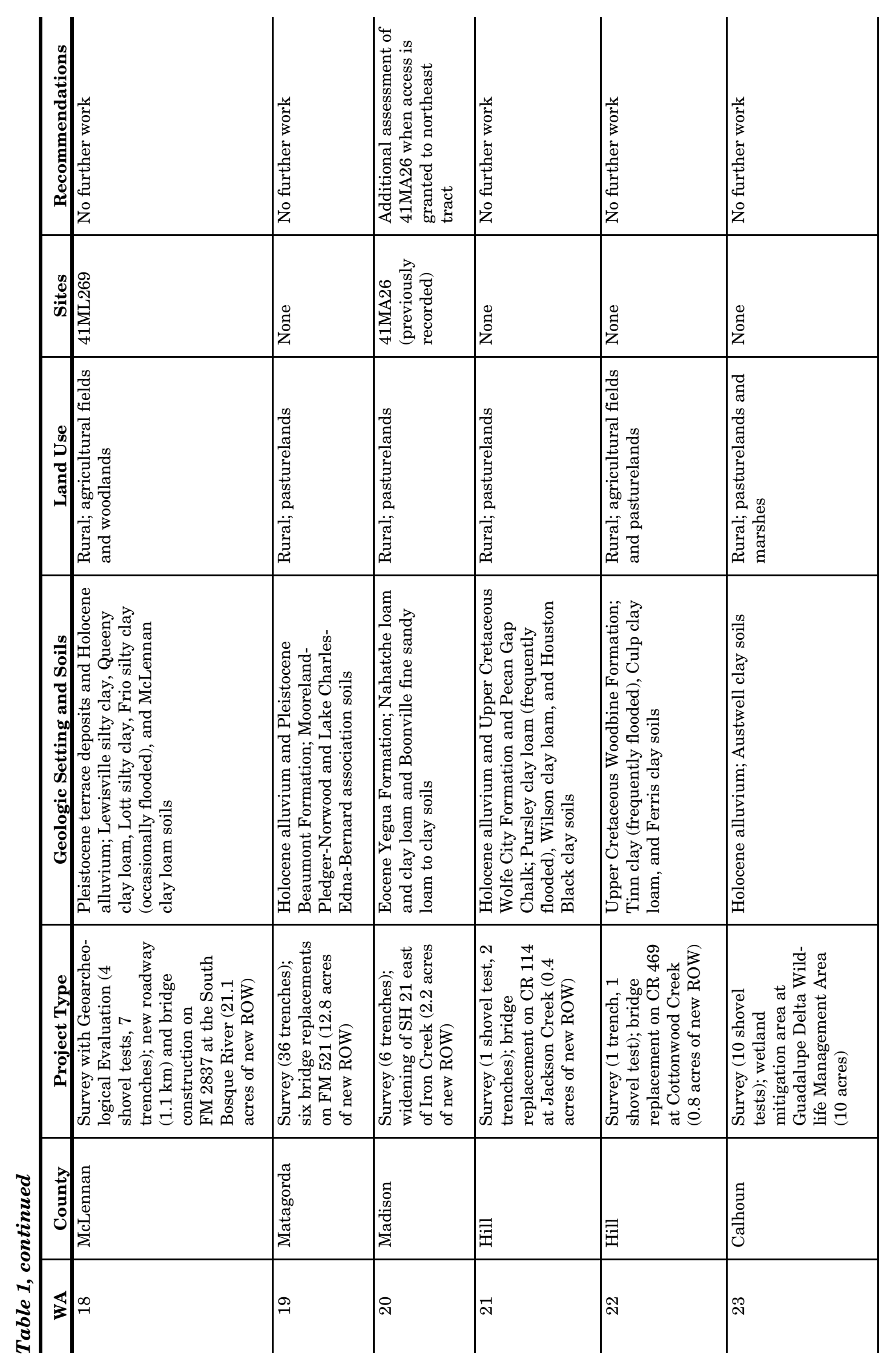


Archeological Impact Evaluations and Surveys

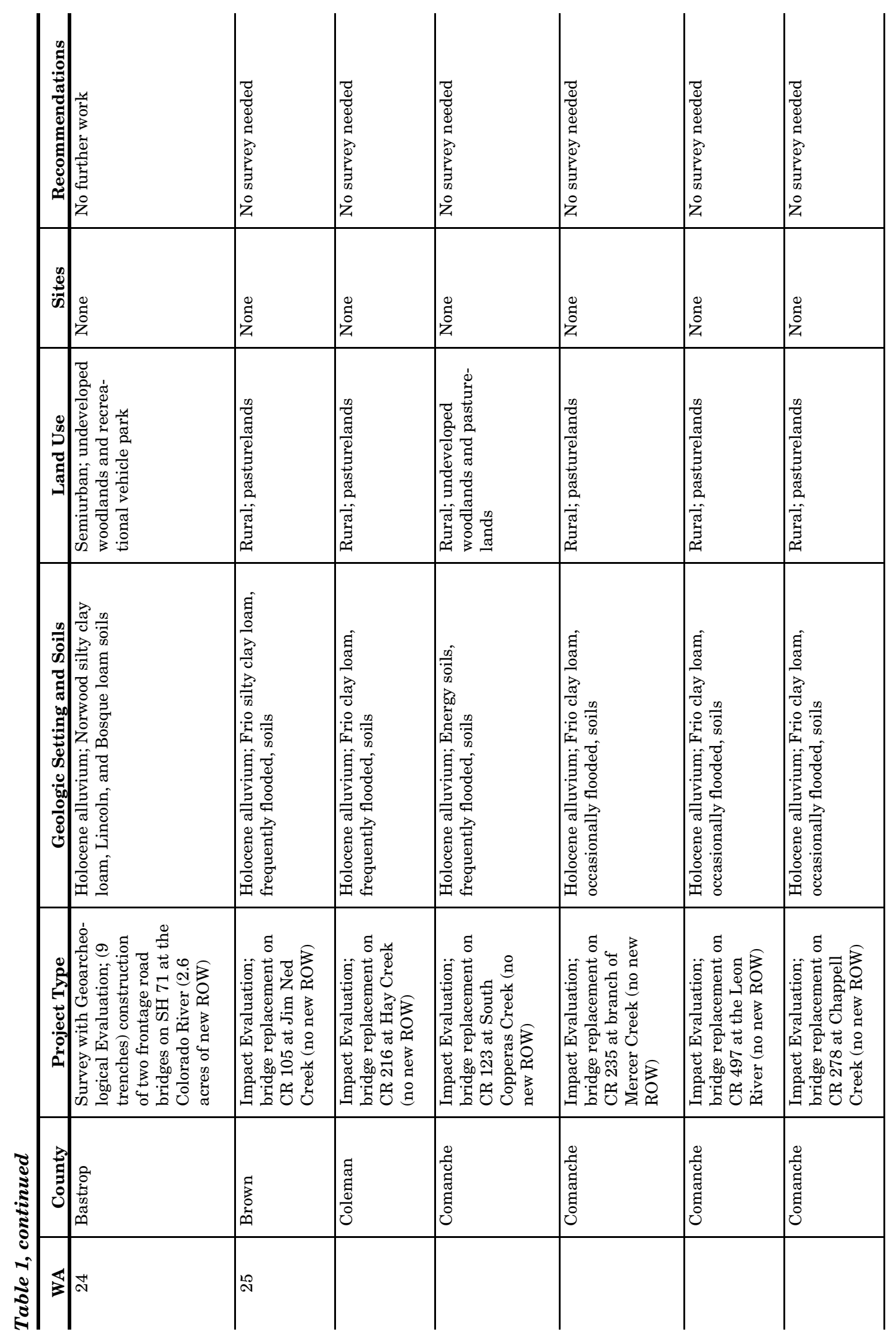


Chapter 3: Summary

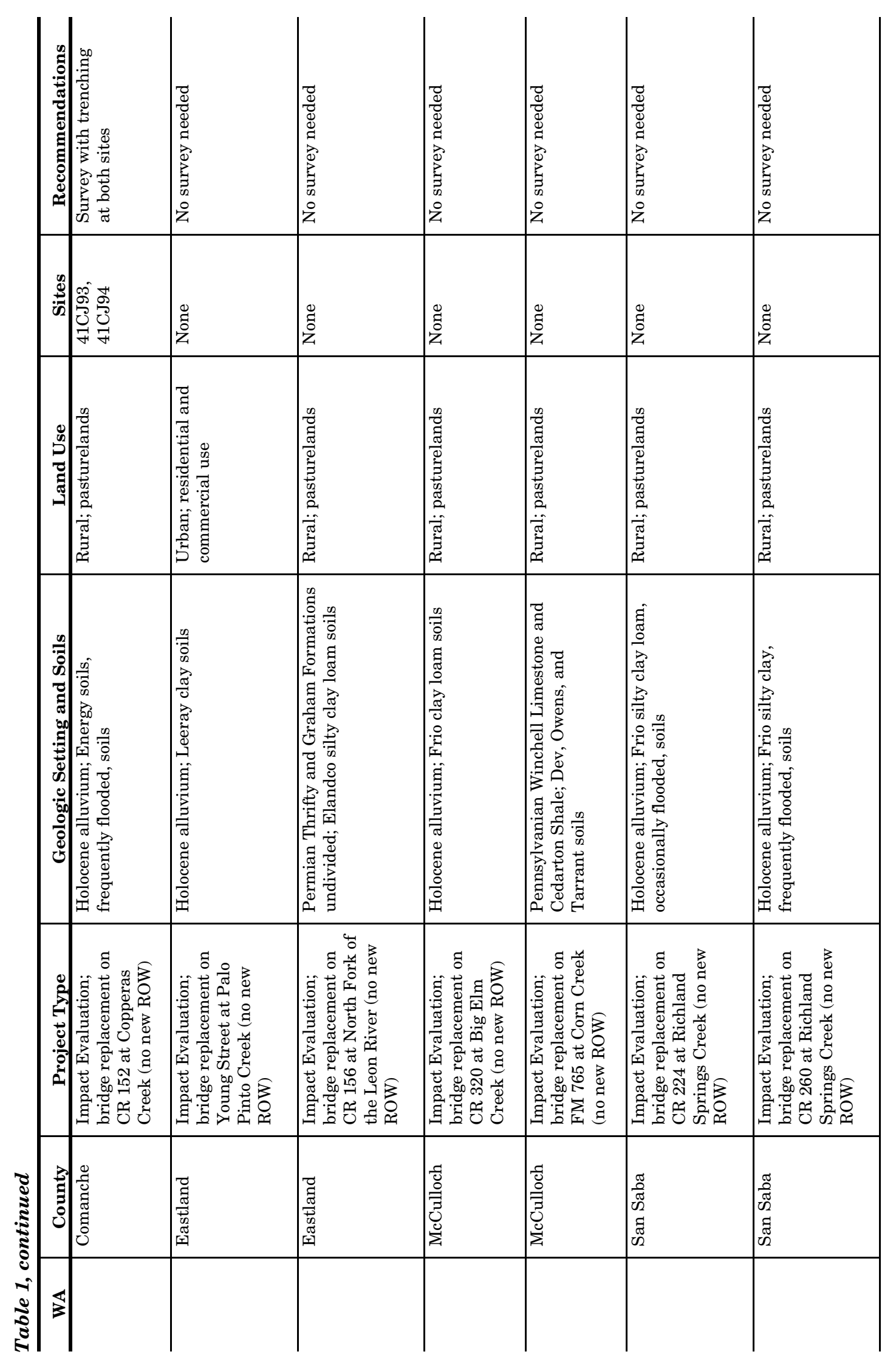


Archeological Impact Evaluations and Surveys

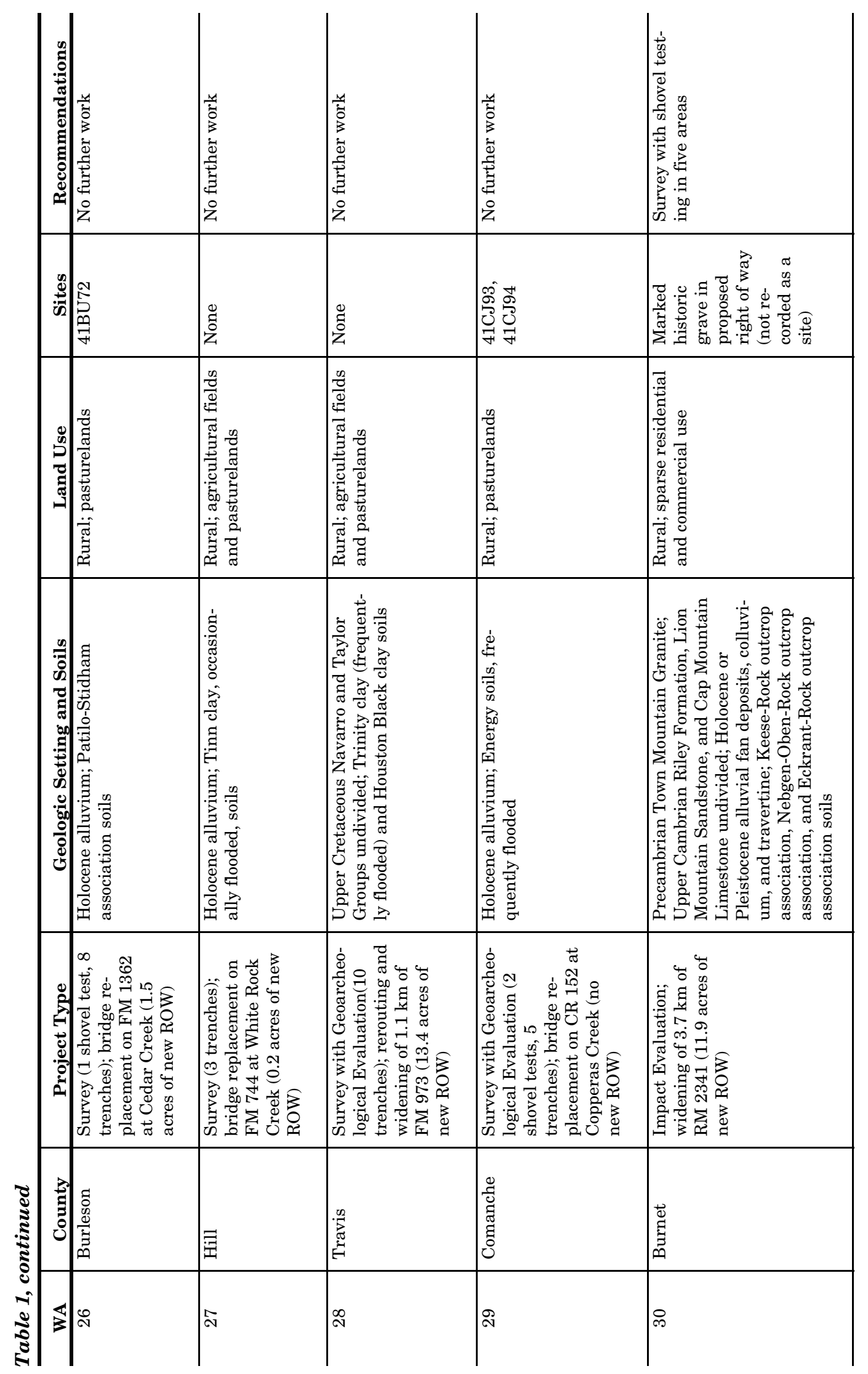




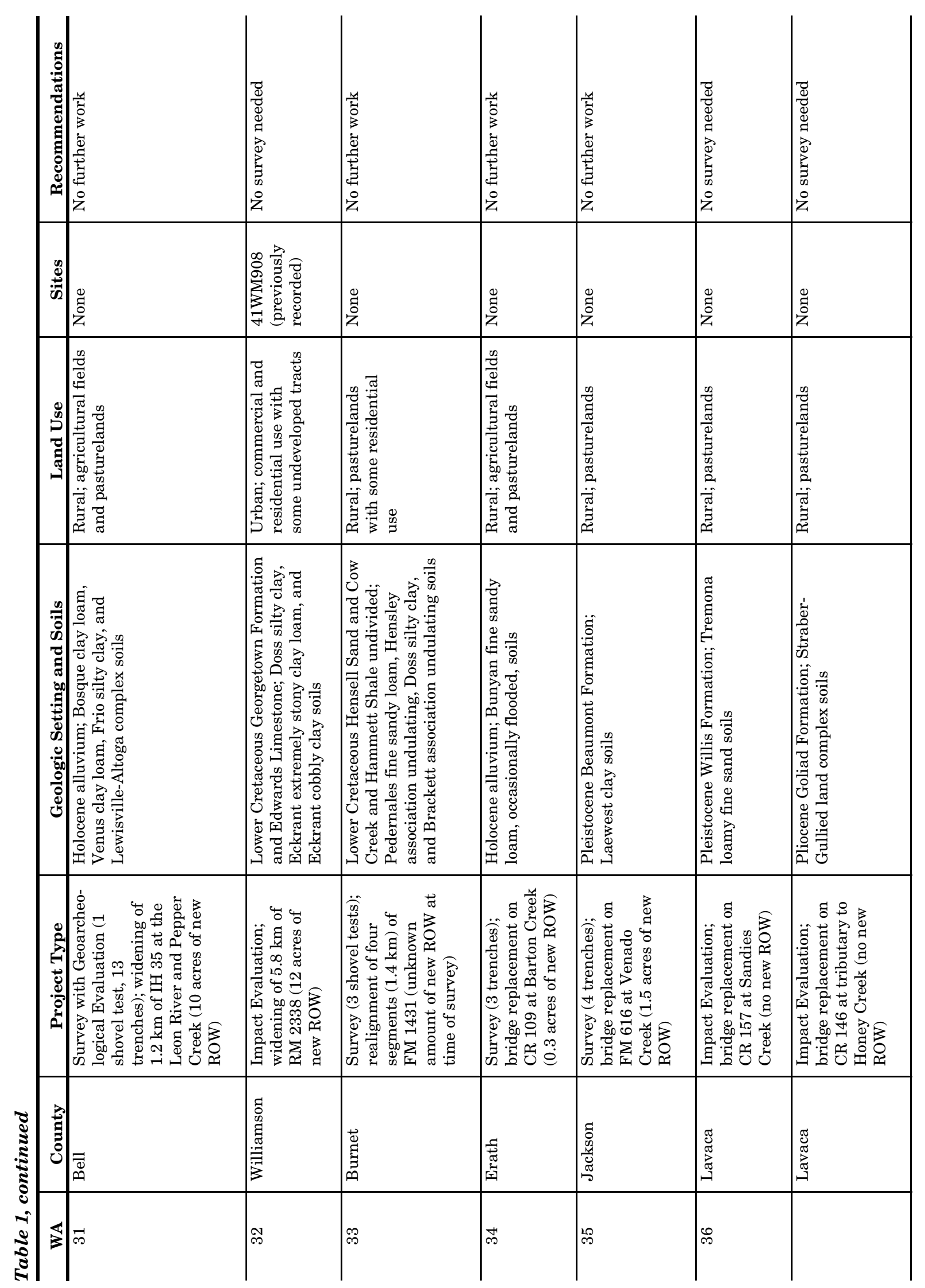




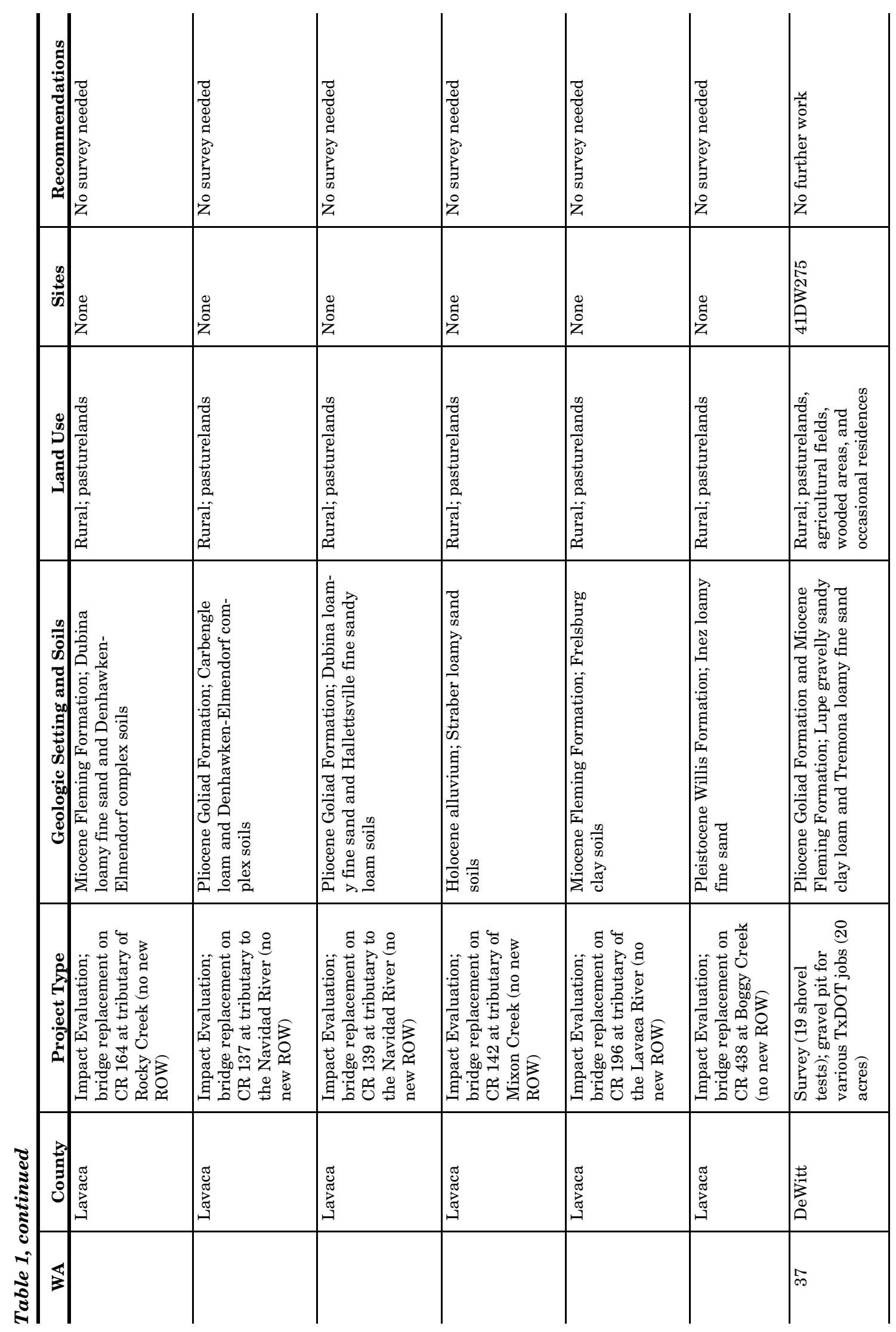


Chapter 3: Summary

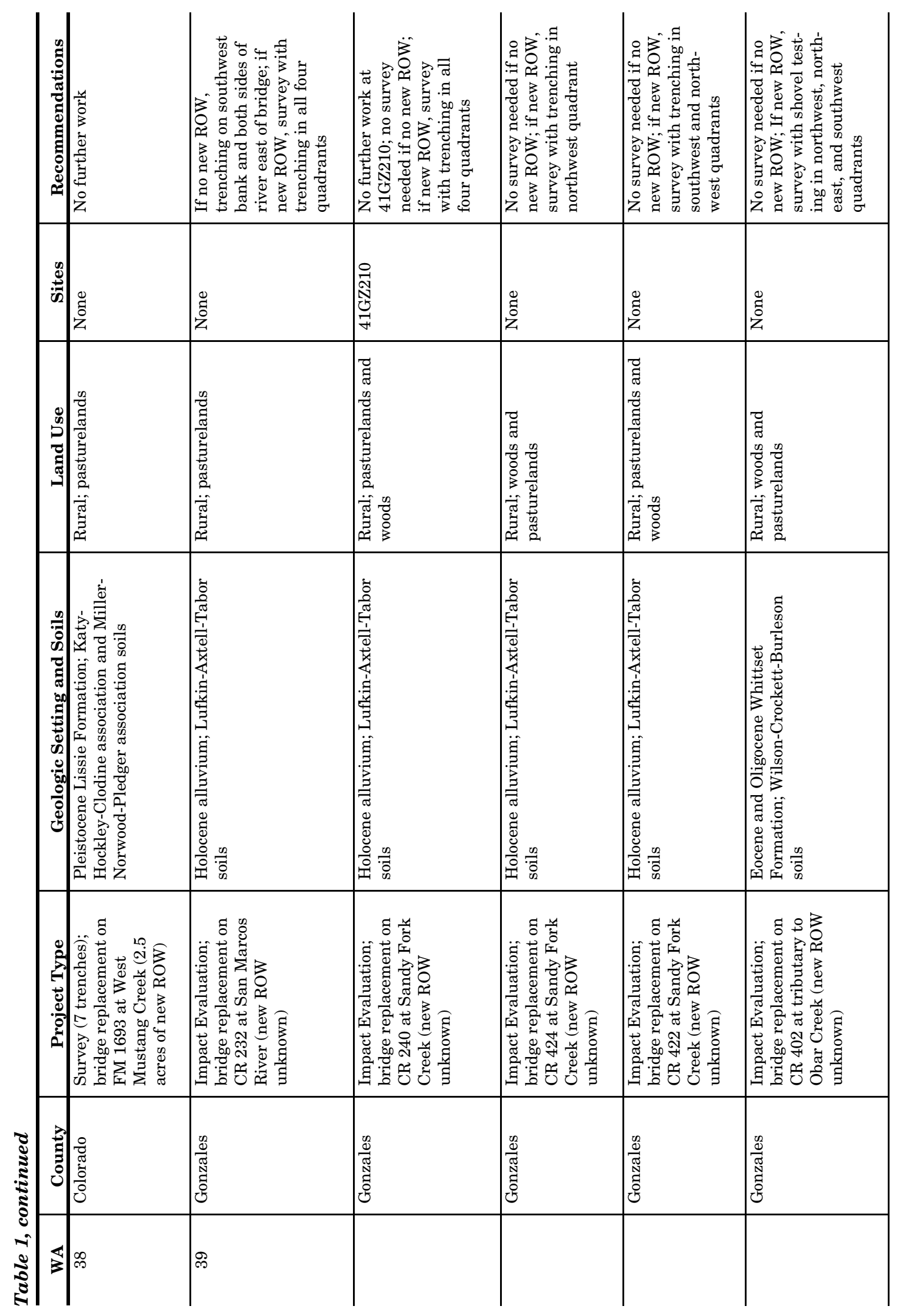


Archeological Impact Evaluations and Surveys

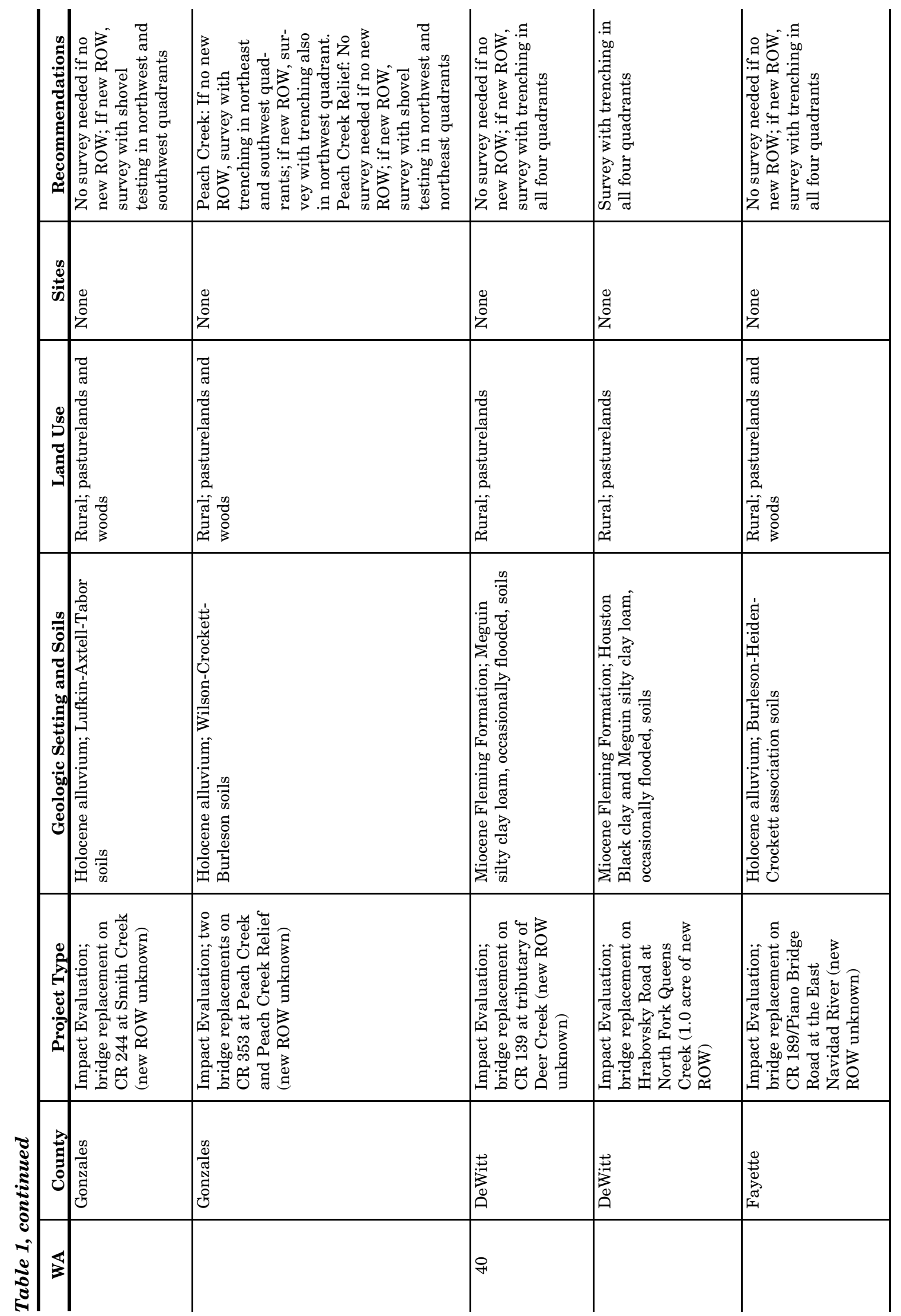


Chapter 3: Summary

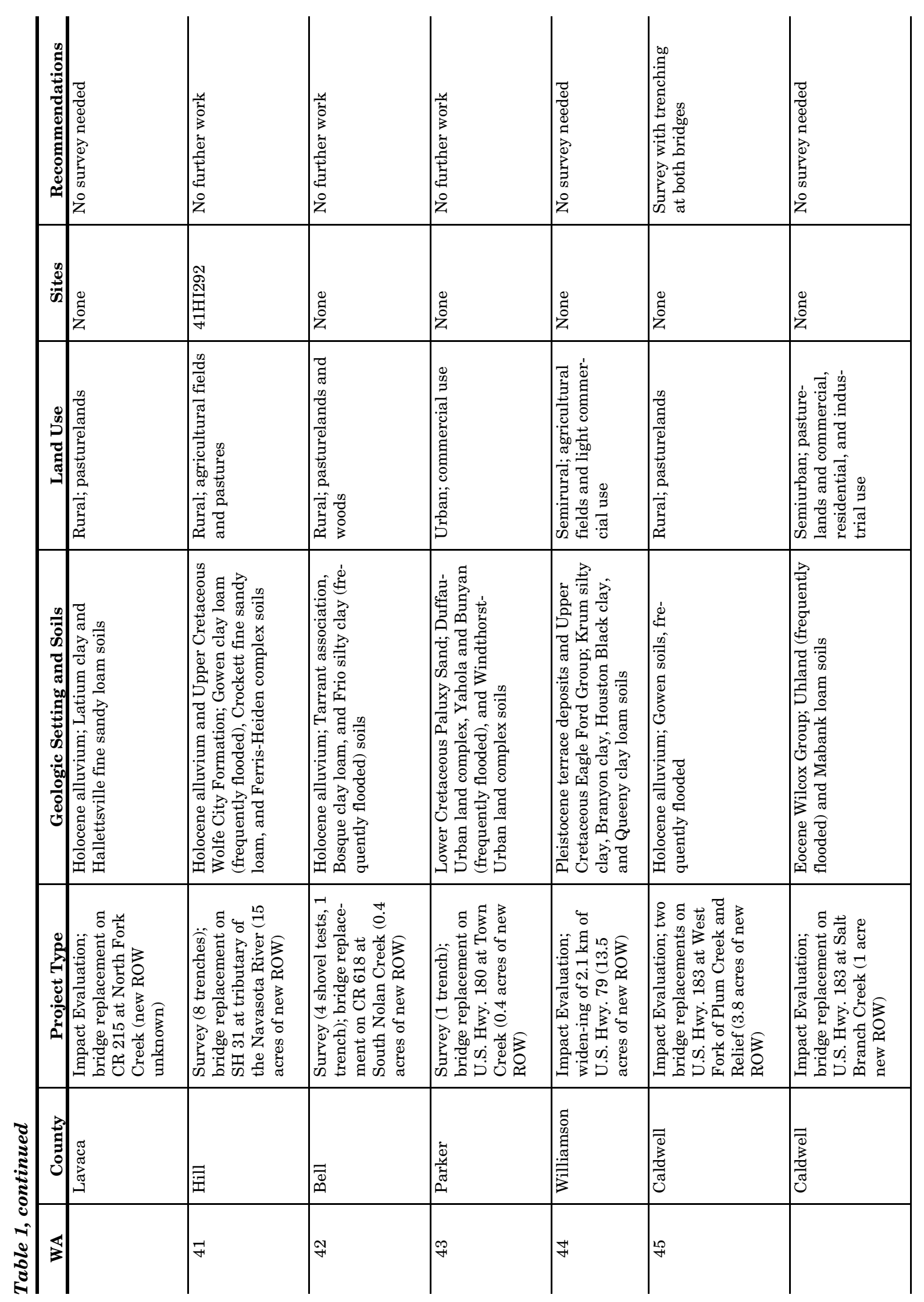


Archeological Impact Evaluations and Surveys

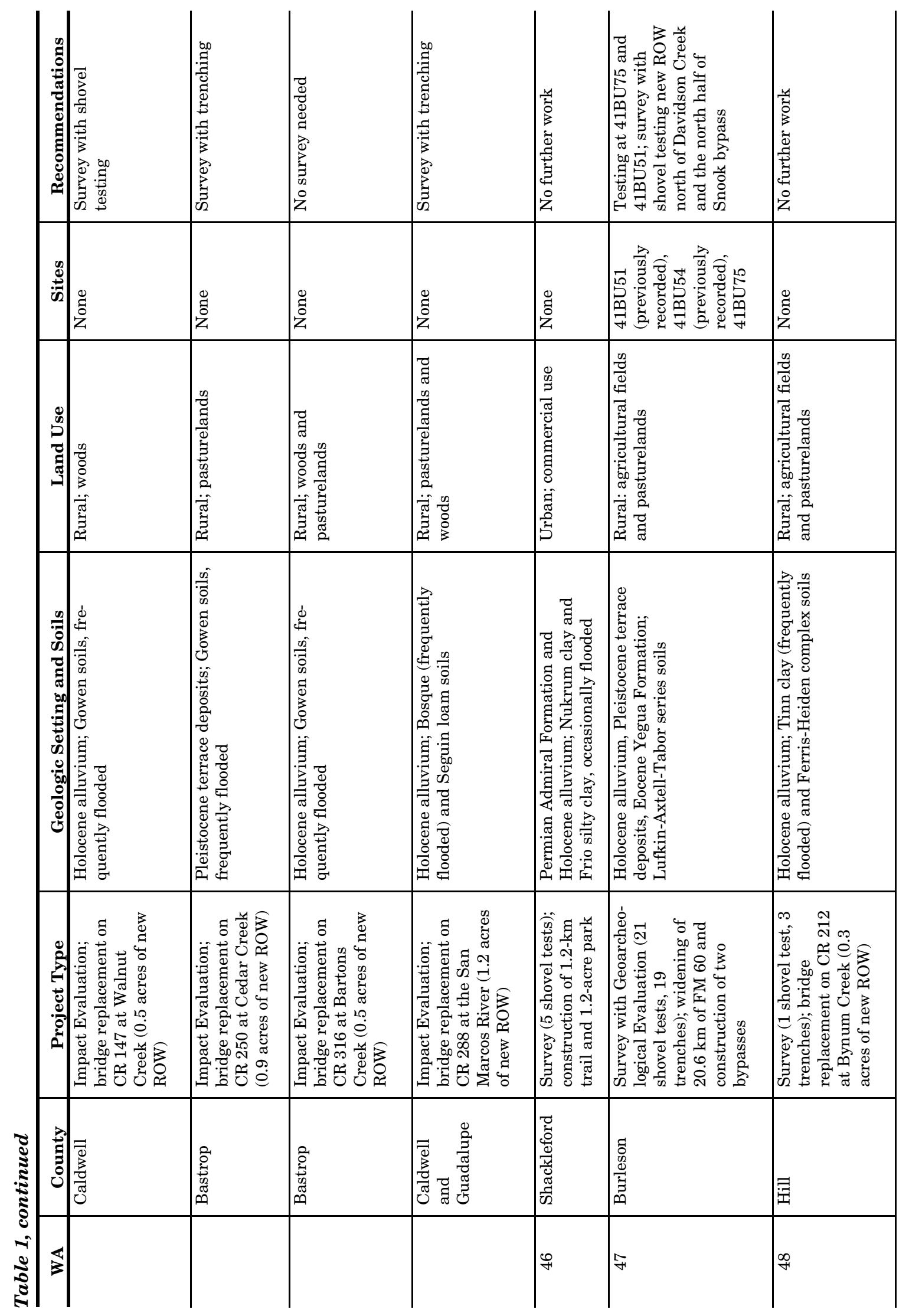


Chapter 3: Summary

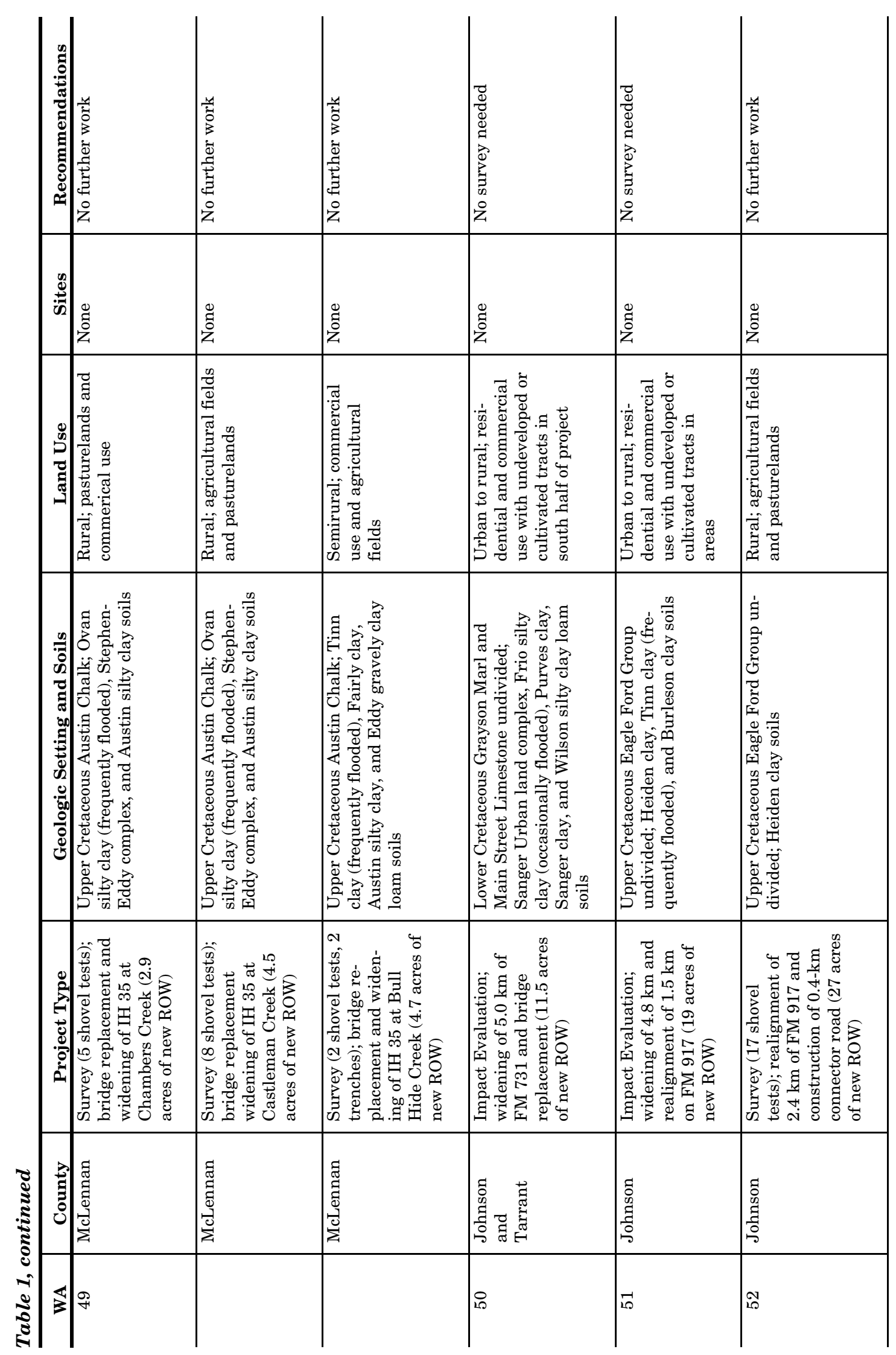


Archeological Impact Evaluations and Surveys

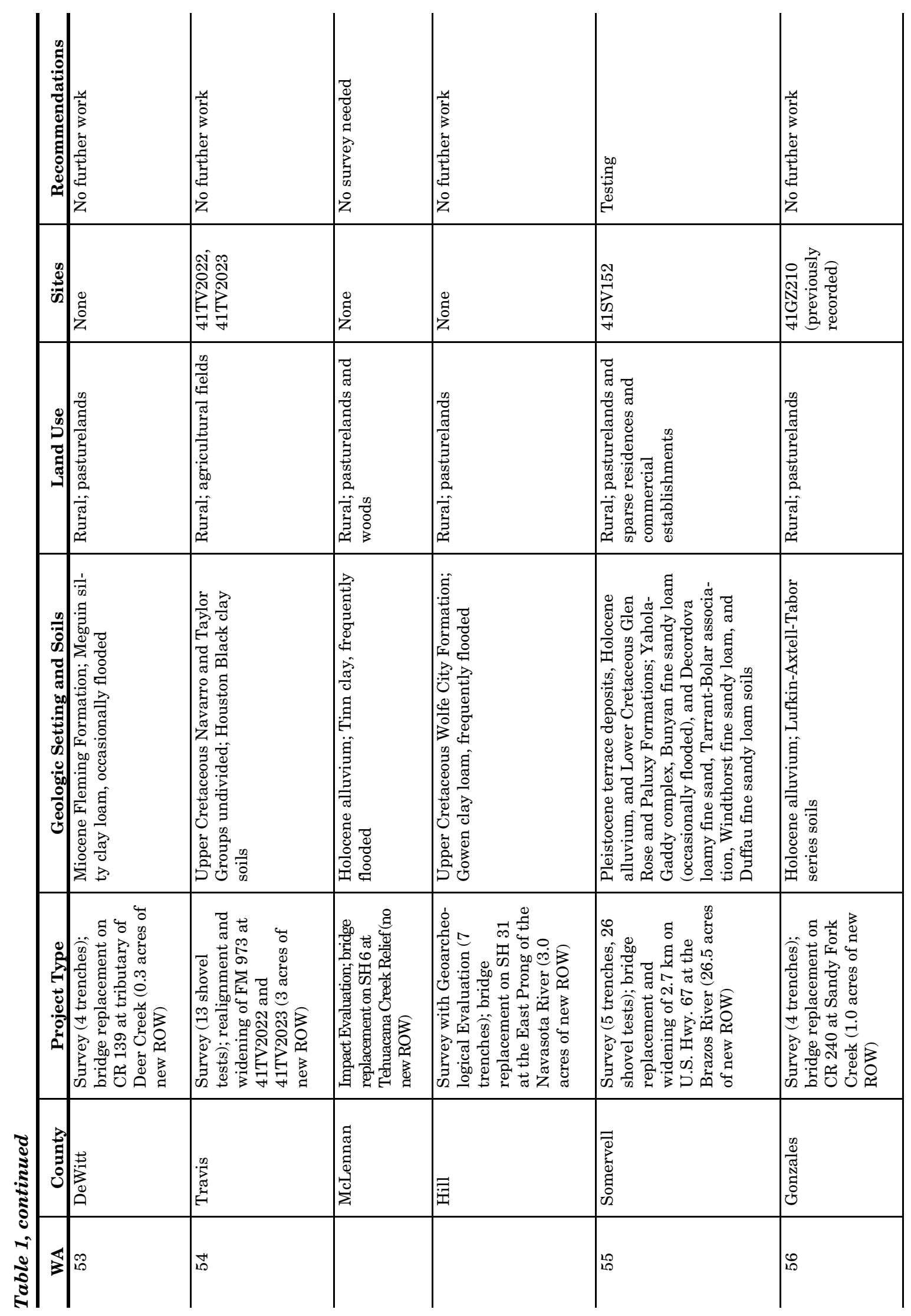


Chapter 3: Summary

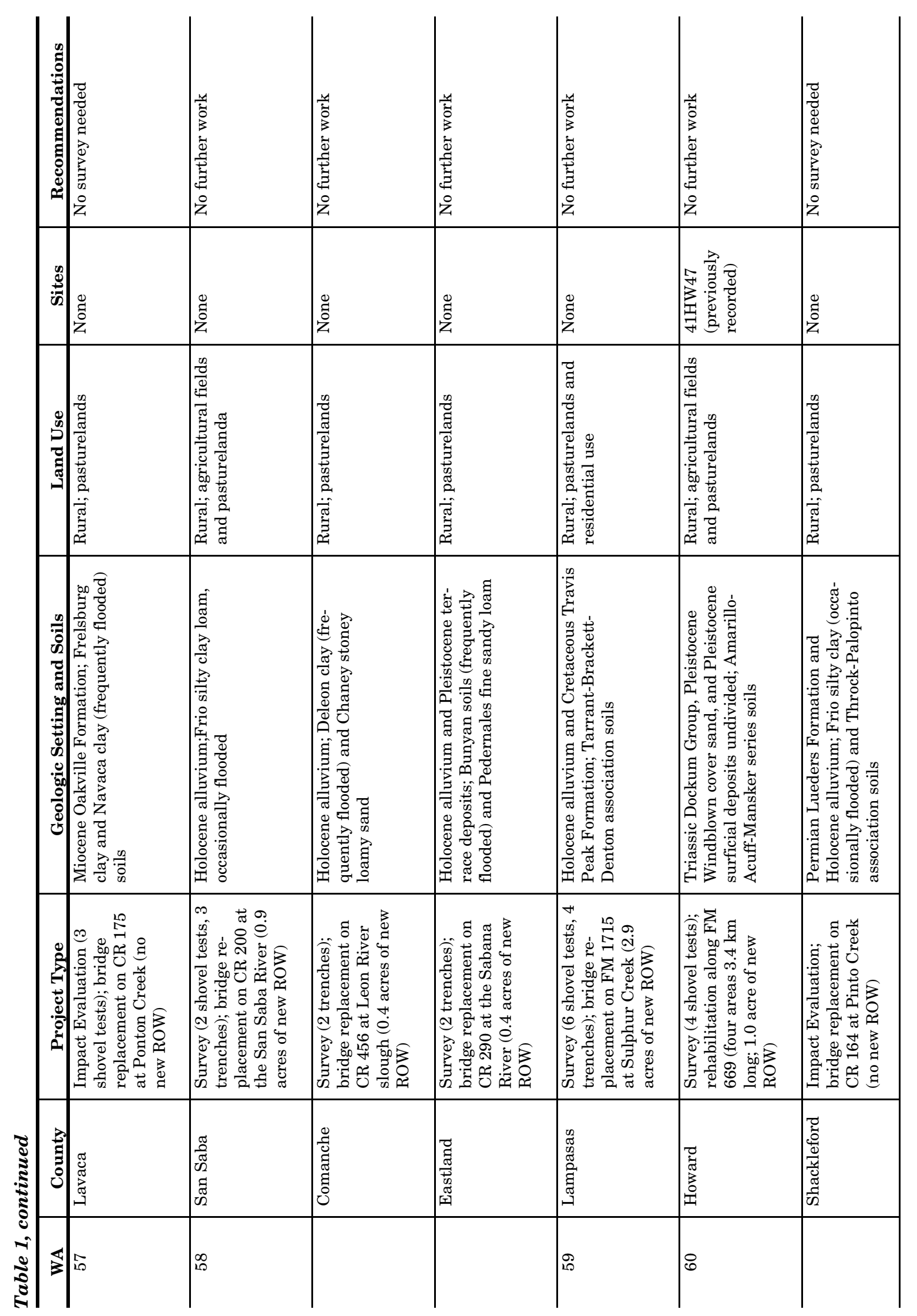


Archeological Impact Evaluations and Surveys

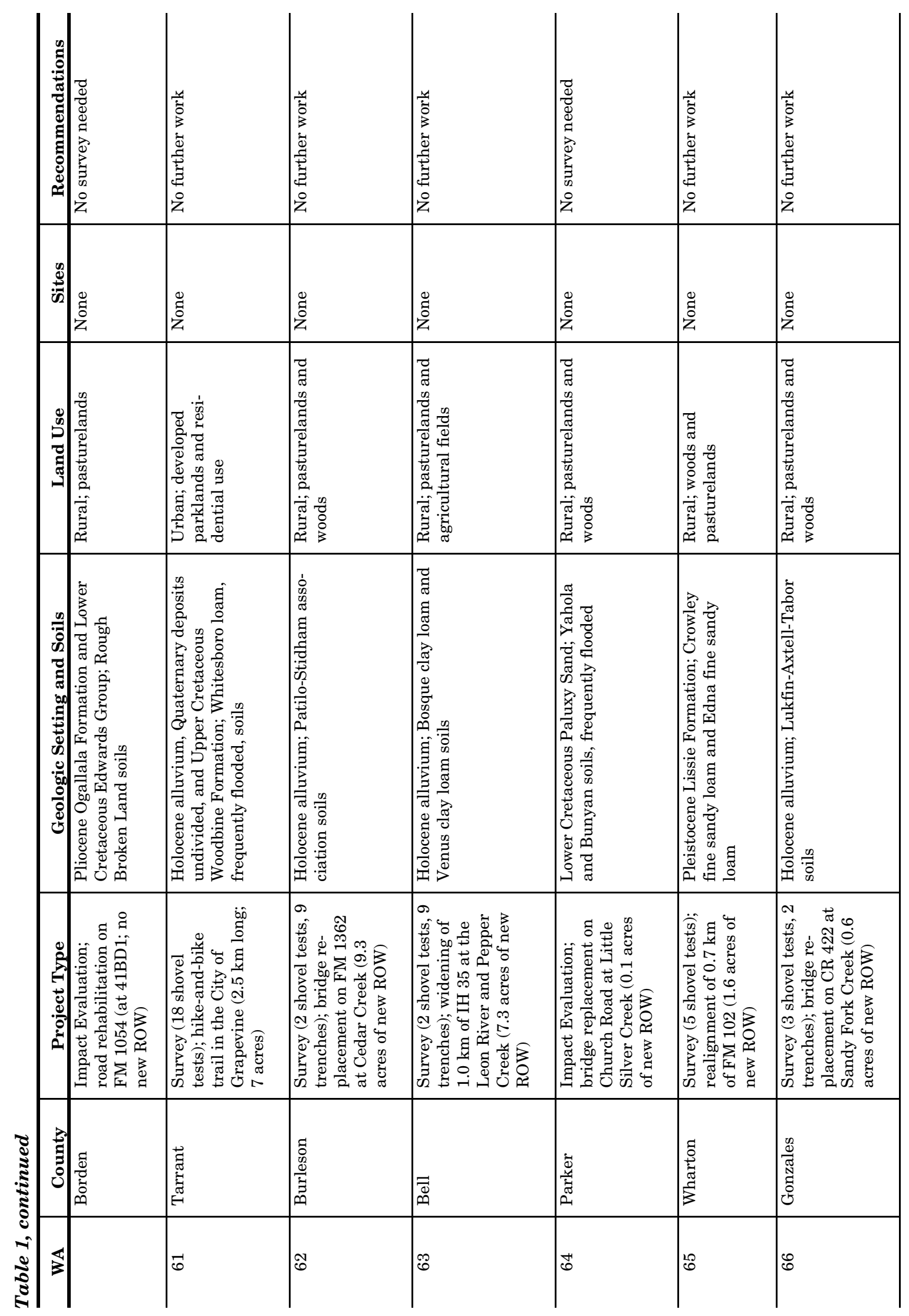


Chapter 3: Summary

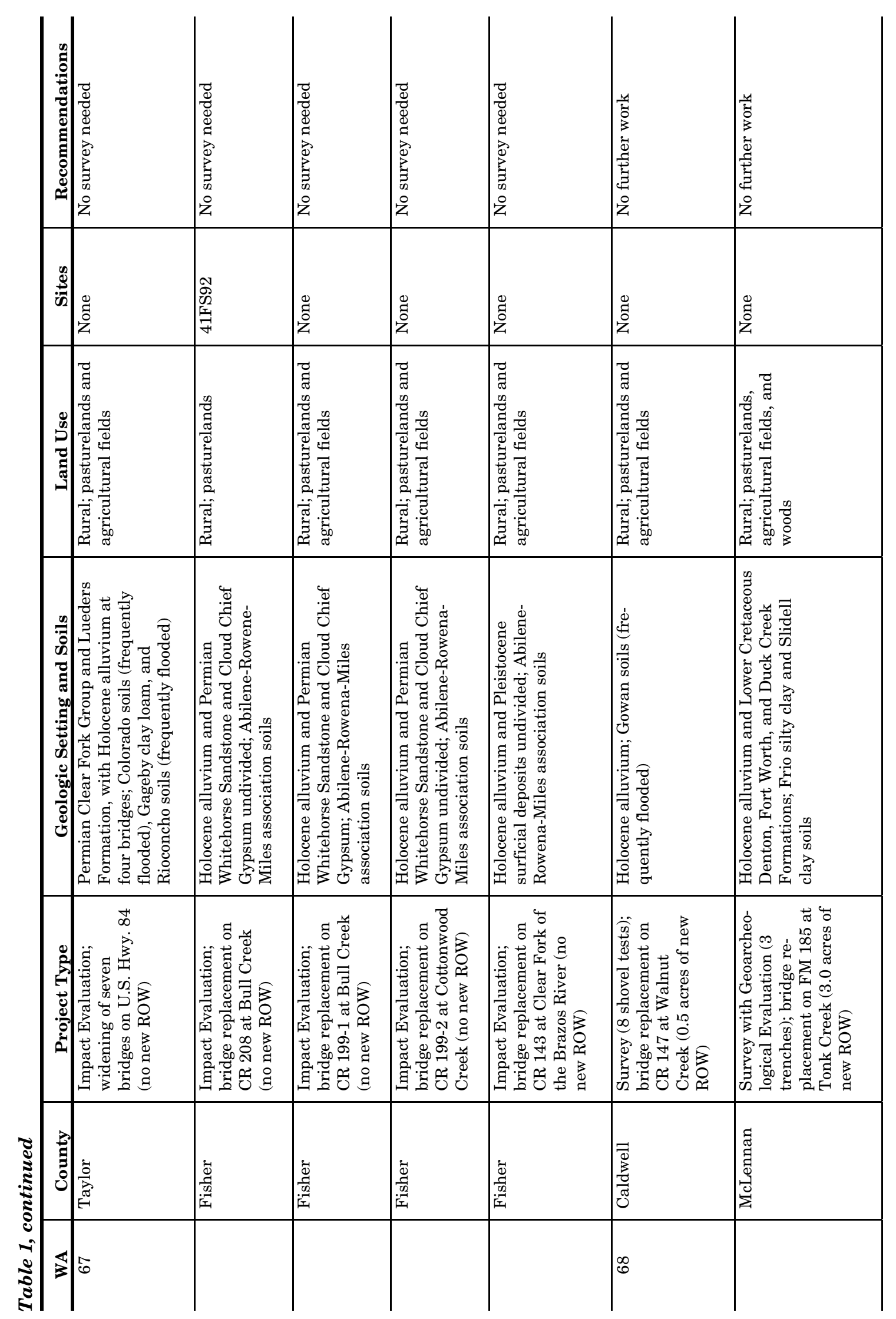




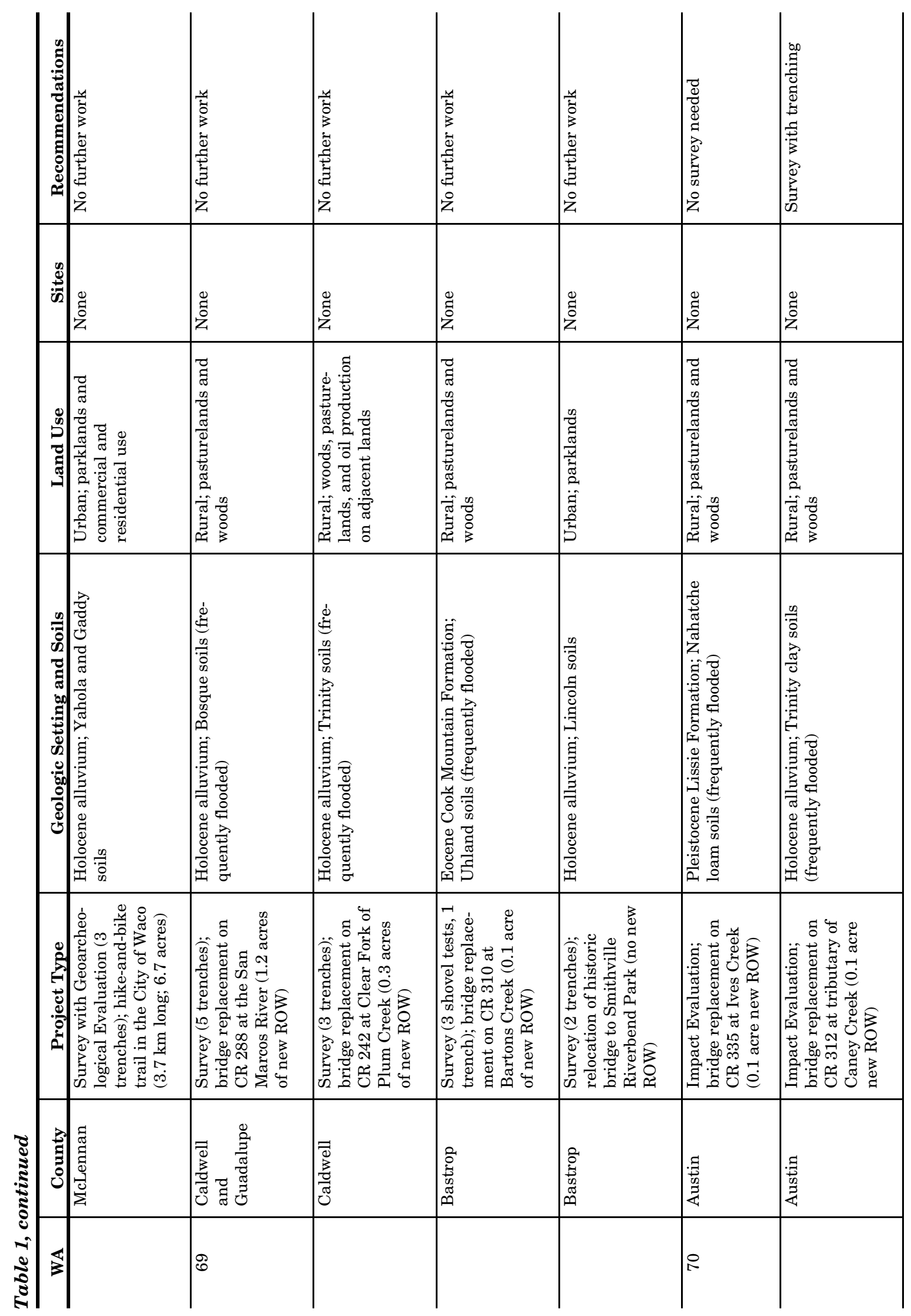


Chapter 3: Summary

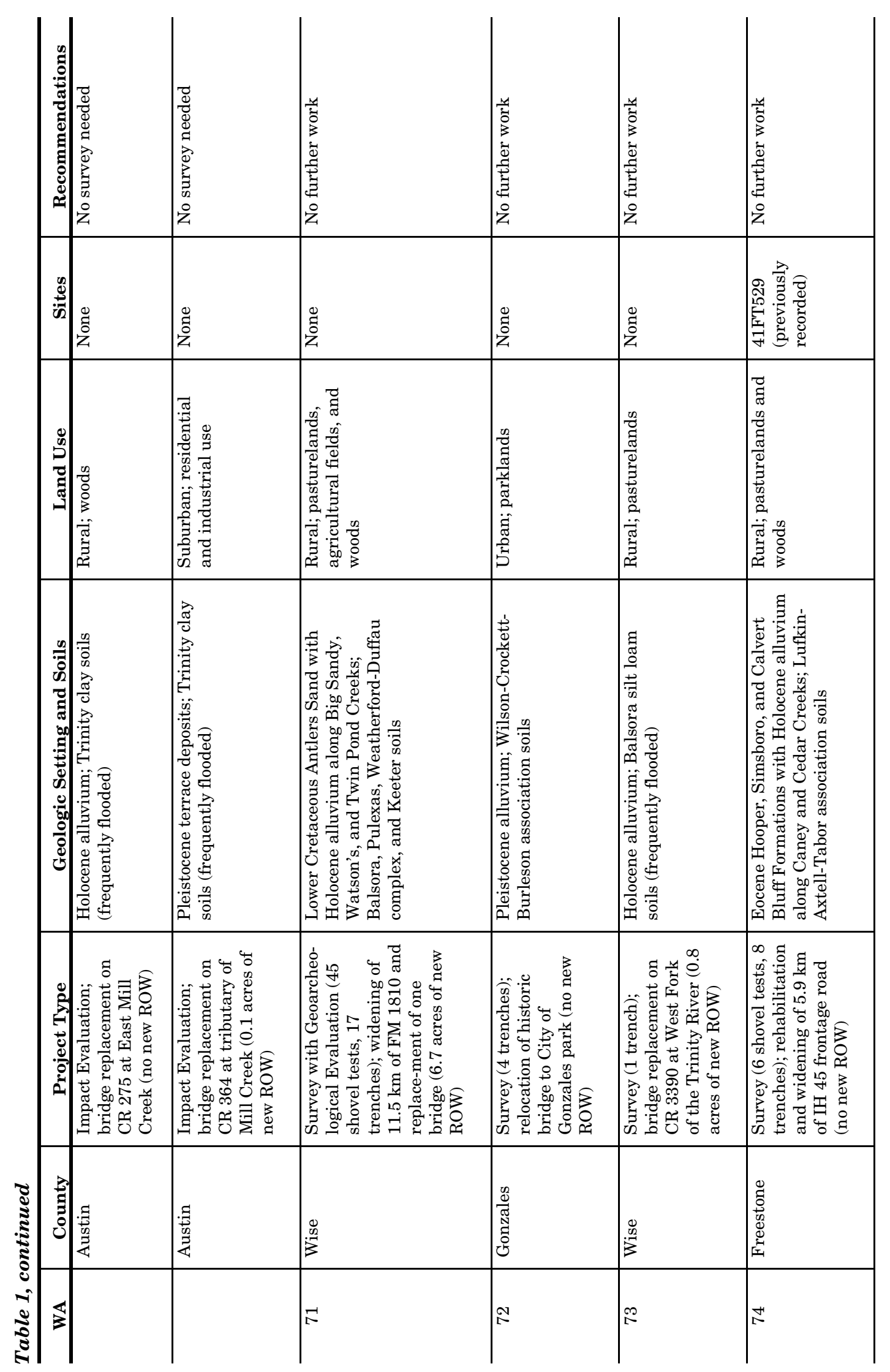


Archeological Impact Evaluations and Surveys

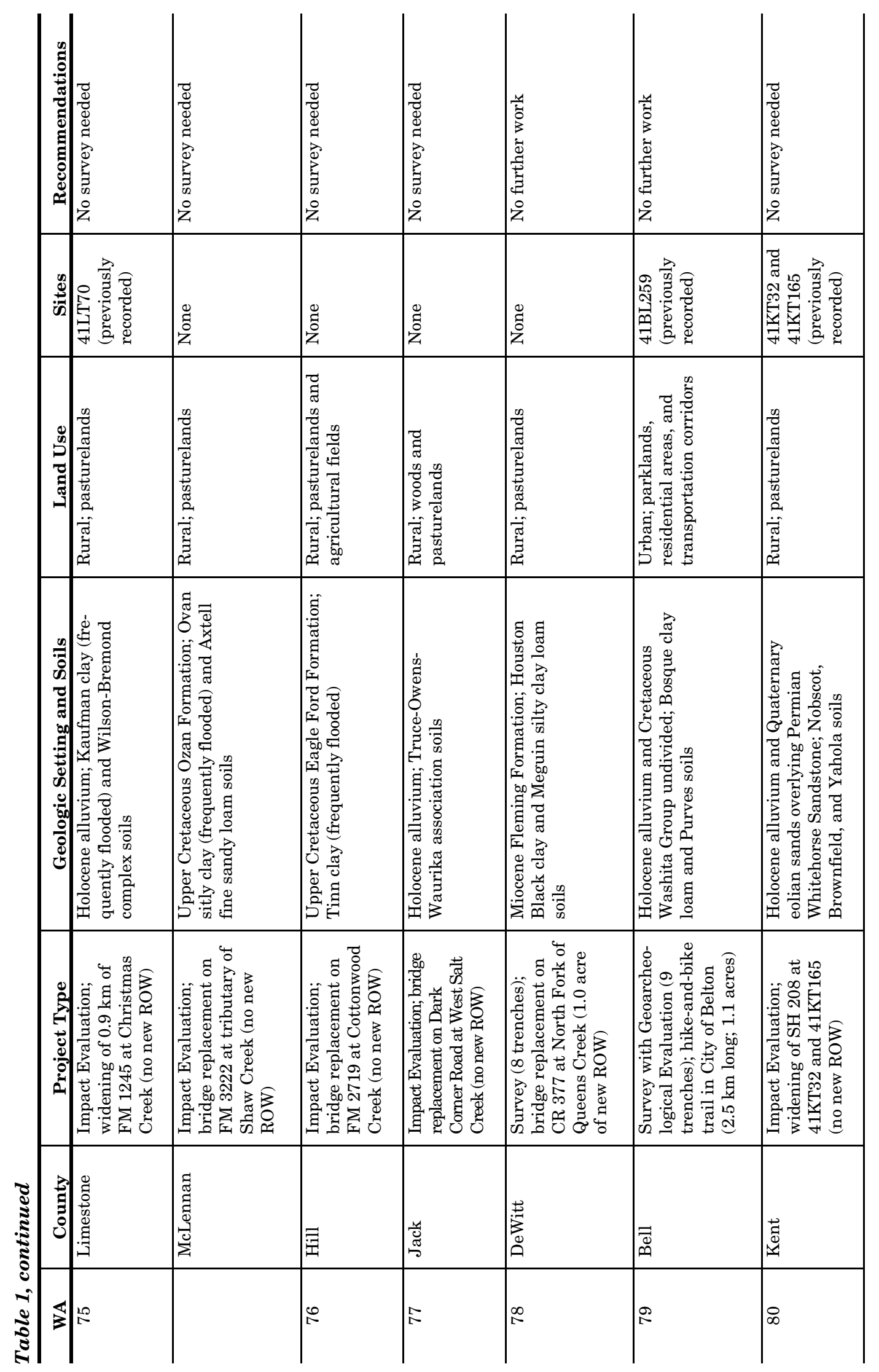


Chapter 3: Summary

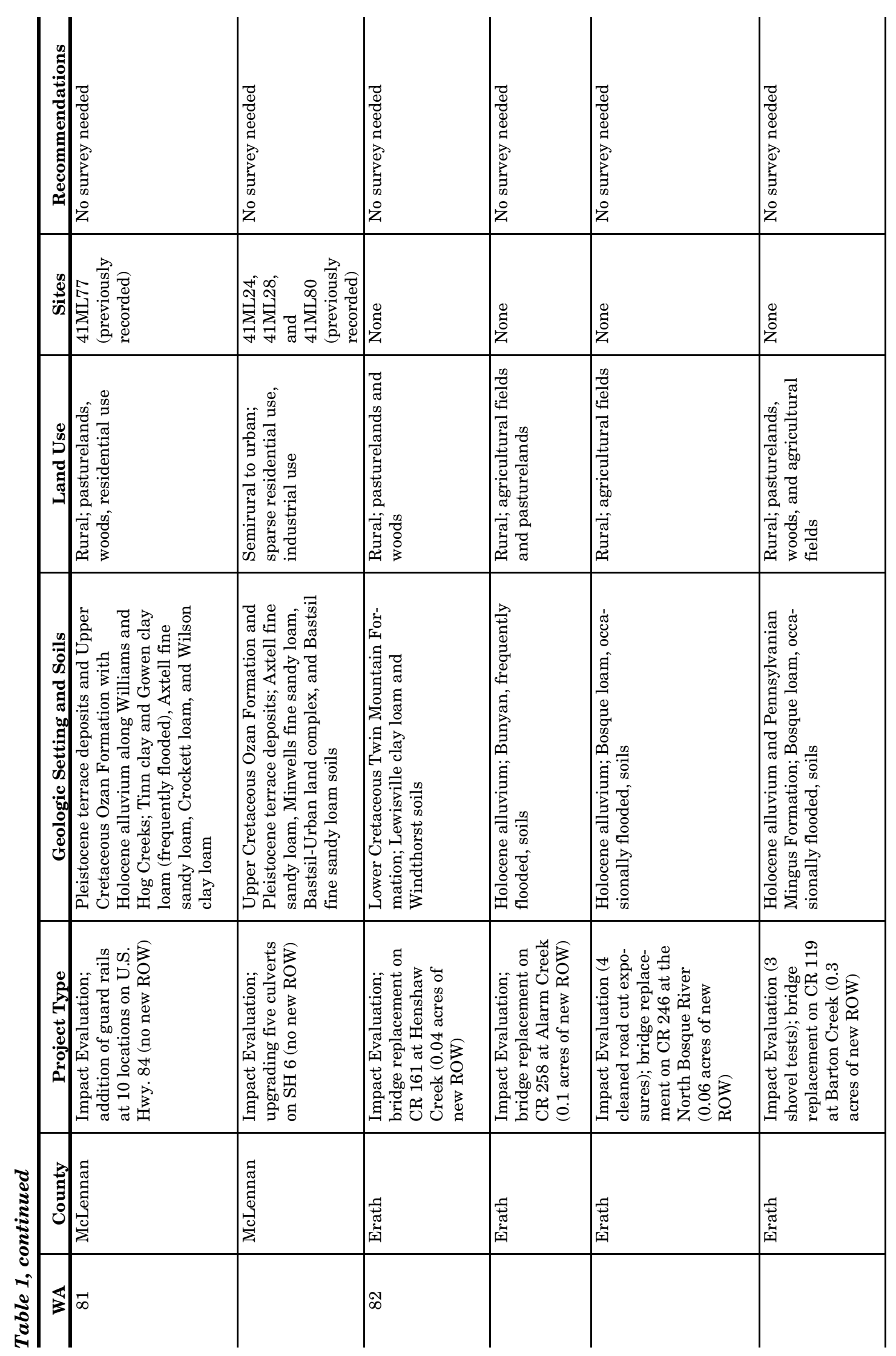


Archeological Impact Evaluations and Surveys

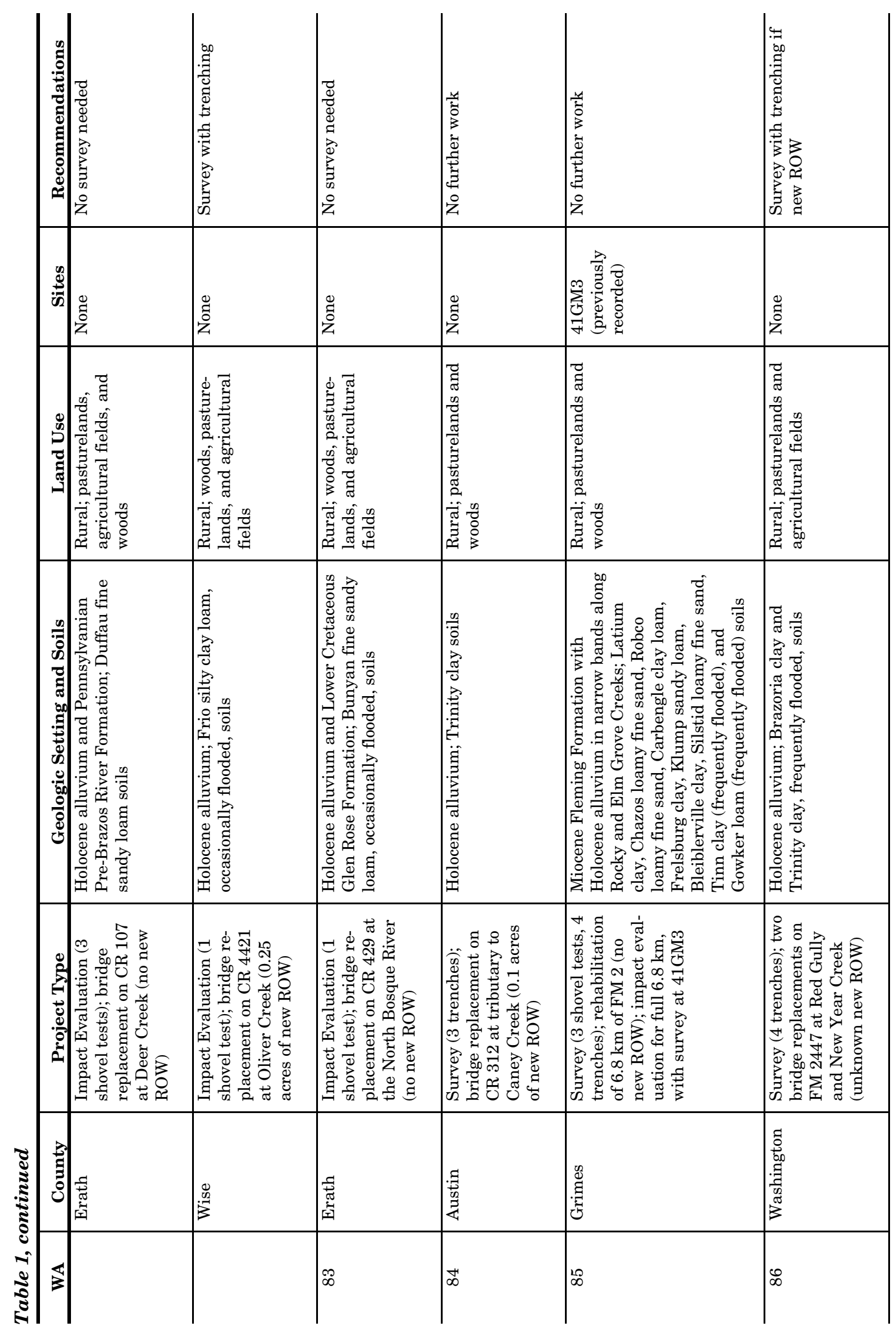


Chapter 3: Summary

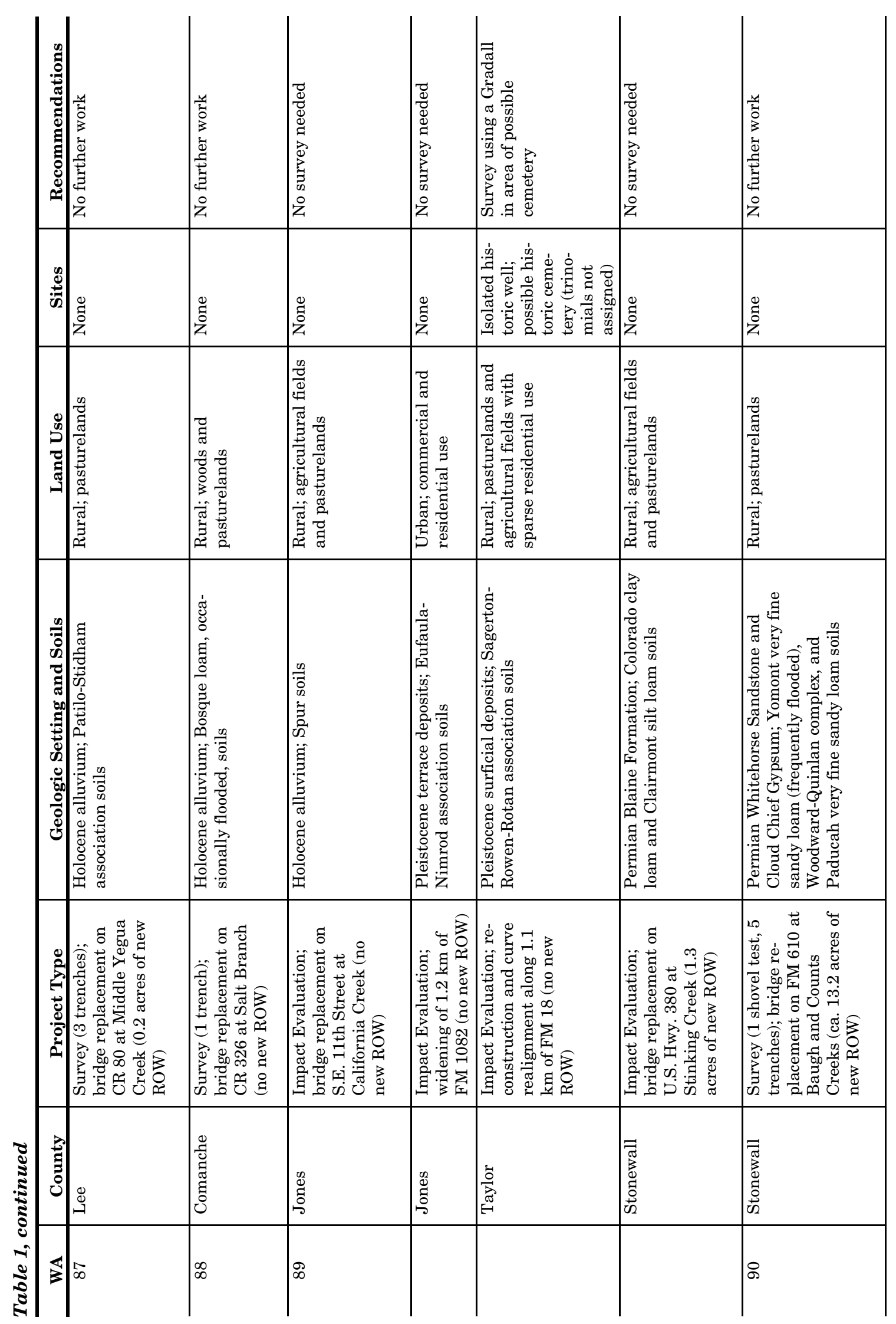


Archeological Impact Evaluations and Surveys

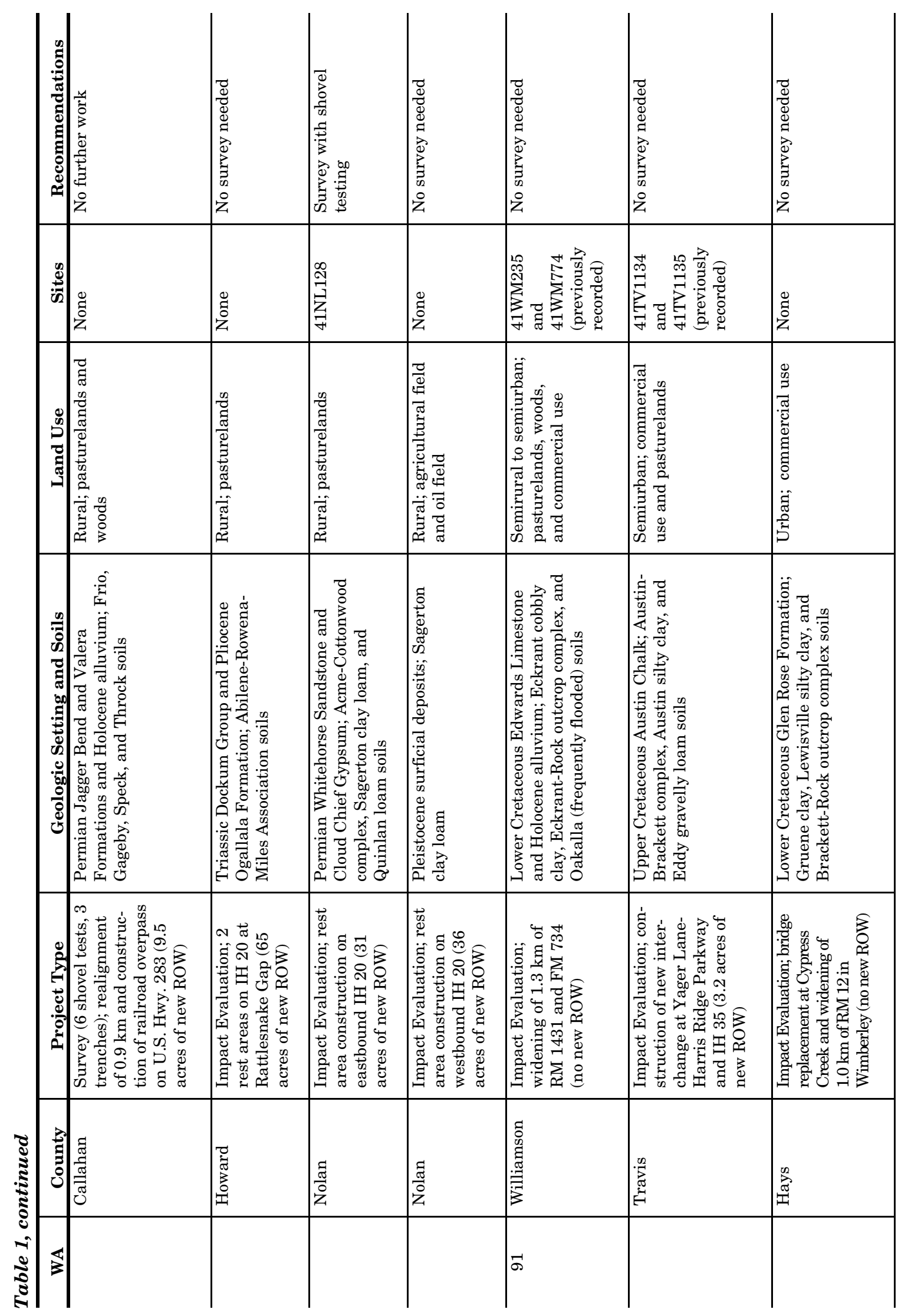


Chapter 3: Summary

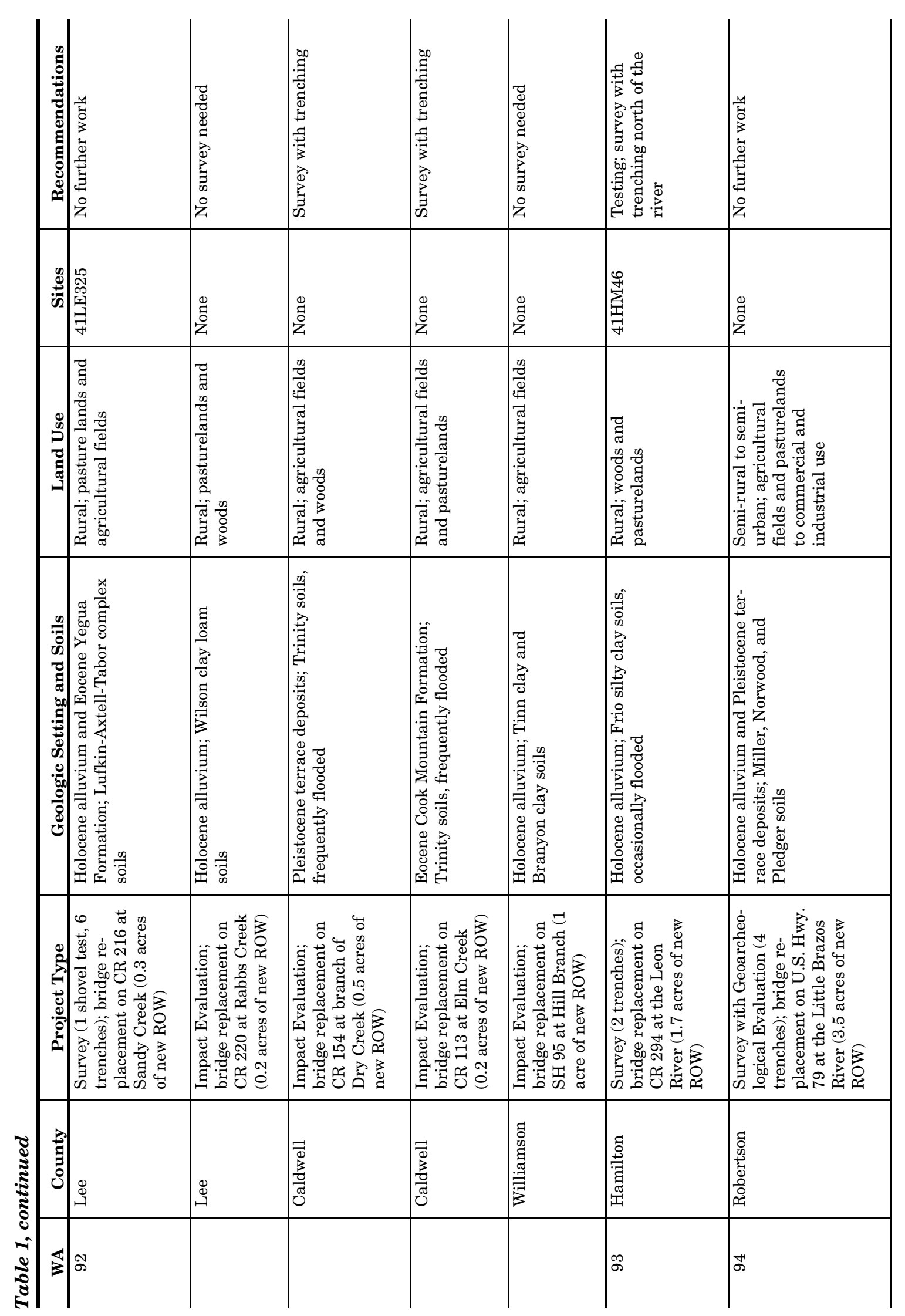


Archeological Impact Evaluations and Surveys

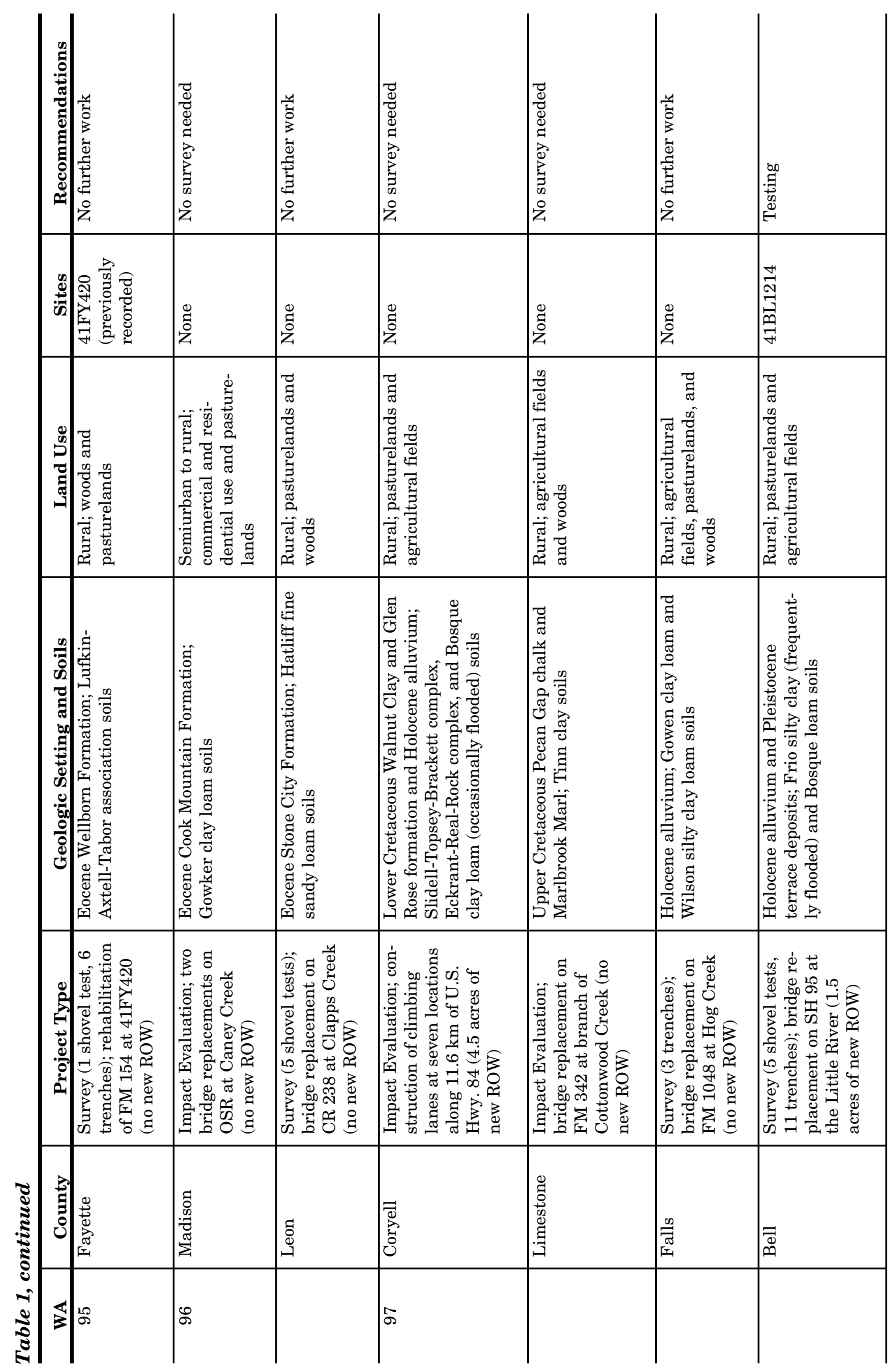


Chapter 3: Summary

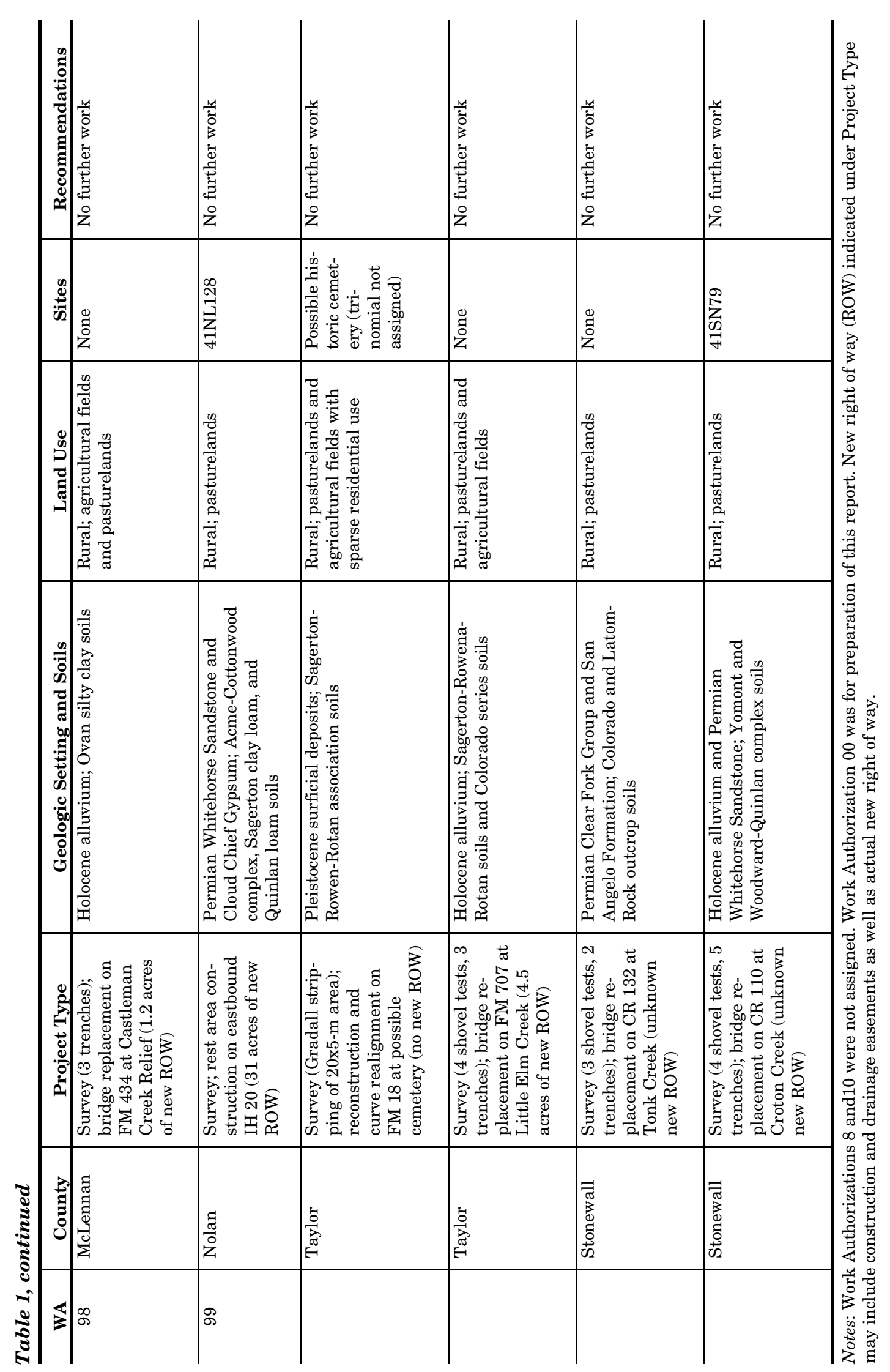


Archeological Impact Evaluations and Surveys

\section{SYNOPSIS OF WORK AUTHORIZATIONS}

As listed in Table 1, 26 of the 182 projects involving fieldwork were in the Abilene District (Borden, Callahan, Fisher, Howard, Jones, Kent, Nolan, Shackleford, Stonewall, and Taylor Counties), 31 were in the Austin District (Bastrop, Burnet, Caldwell, Hays, Lee, Travis, and Williamson Counties), 21 were in the Brownwood District (Brown, Coleman, Comanche, Eastland, Lampasas, McCulloch, and San Saba Counties), 12 were in the Bryan District (Burleson, Freestone, Grimes, Leon, Madison, Milam, and Robertson Counties), 19 were in the Fort Worth District (Erath, Jack, Johnson, Parker, Somervell, Tarrant, and Wise Counties), 34 were in the Waco District (Bell, Coryell, Falls, Hamilton, Hill, Limestone, and McLennan Counties), and 39 were in the Yoakum District (Austin, Calhoun, Colorado, DeWitt, Fayette, Gonzales, Jackson, Lavaca, Matagorda, Washington, and Wharton Counties).

The projects in the Abilene District consisted of 16 Impact Evaluations and 10 Surveys for replacing 14 bridges, upgrading 7 existing bridges or culverts, widening or realigning 7 roads, constructing 4 new rest areas, and constructing 1 hike-and-bike trail. In the Austin District, the work authorizations were for 17 Impact Evaluations, 12 Surveys, and 2 Surveys with Geoarcheological Evaluations on 19 bridge replacements, 7 projects involving road widening or realignment, construction of 4 new roads or bridges, replacement of 1 highway interchange, and relocation of 1 historic-age bridge to a public park. The projects in the Brownwood District consisted of 13 Impact Evaluations, 5 Surveys, and 3 Surveys with Geoarcheological Evaluations for 19 bridge replacements, realignment or widening of 2 roads, and construction of 1 new road. The Bryan District projects involved 3 Impact Evaluations, 7 Surveys, and 2 Surveys with Geoarcheological Evaluation for replacing 8 bridges and rehabilitating or widening 5 roads. In the Fort Worth District, the work authorizations were for 11 Impact Evaluations, 7 Surveys, and 1 Survey with Geoarcheological Evaluation on 12 bridge replacements, 6 road realignment or widening projects, 1 project involving new road construction, and 1 hike-and-bike trail construction project. The projects in the Waco District consisted of 10 Impact Evaluations, 18 Surveys, and 6 Surveys with Geoarcheological Evaluations for 17 bridge replacements, upgrading of 2 bridges or culverts, 11 road realignments or widening efforts, 1 new road construction project, 1 borrow pit project, and 2 hike-and-bike trail projects. Finally, the Yoakum District projects consisted of 24 Impact Evaluations and 15 Surveys for replacement of 39 bridges, realignment or rehabilitation of 2 roads, relocation of 1 historic-age bridge to a public park, creation of 1 wetland mitigation area, and creation of 1 gravel pit.

Sixty-nine of the projects, most involving bridge replacements, were restricted to settings mapped as Holocene alluvium (see Table 1). Another 38 Impact Evaluations and Surveys encompassed upland margins as well as Holocene alluvium, with the uplands mapped as a variety of Pre-Cambrian (Town Mountain Granite), Cambrian (Cap Mountain Limestone, Lion Mountain Sandstone, and Riley), Pennsylvanian (Mingus and Pre-Brazos River), Permian (Admiral, Clear Fork, Cloud Chief Gypsum, Jagger Bend, Lueders, Valera, and Whitehorse Sandstone), Cretaceous (Antlers Sand, Denton, Duck Creek, Edwards Limestone, Fort Worth, Glen Rose, Goodland Limestone, Ozan, Paluxy, Pecan Gap Chalk, Travis Peak, Walnut Clay, Washita Group, Wolfe City, and Woodbine), Eocene (Calvert Bluff, Carrizo Sand, Hooper, Simsboro, and Yegua), Miocene (Fleming), and Pleistocene (Beaumont, surficial deposits undivided, eolian sands, and fluviatile terrace) deposits. The 75 projects that were mostly in upland areas crossed the Pennsylvanian Cedarton Shale, Strawn Group, and Winchell Limestone Formations; Permian Blaine, Clear Fork Group, Cloud Chief Gypsum, San Angelo, Thrifty and Graham undivided, and Whitehorse Sandstone Formations; Triassic Dockum Group; Lower Cretaceous Comanche Peak Limestone, Cow Creek and Hammett Shale undivided, Edwards Limestone, Georgetown, Glen Rose, Grayson Marl, Hensel Sand, Keys Valley Marl, Main Street Limestone, Paluxy Sand, Twin Mountain, and Walnut Clay Formations; Upper Cretaceous Austin Chalk, Eagle Ford, Lake Waco, Marlbrook Marl, Navarro and Taylor Groups undivided, Ozan, Pecan Gap Chalk, South Bosque, Wolfe City, and Woodbine Formations; Eocene Cook Mountain, Hooper, Queen 
City Sand, Reklaw, Stone City, Wellborn, Wilcox Group, and Yegua Formations; Eocene-Oligocene Whittset Formation; Miocene Fleming and Oakville Formations; Pliocene Goliad and Ogallala Formations; and Pleistocene Beaumont, Lissie, and Willis Formations, as well as surficial deposits undivided, eolian sand, and terrace deposits.

A variety of soils are mapped for the project areas, ranging from sandy to clayey, sometimes stony, often shallow soils in the western part of the study area to dark, calcareous, clayey soils of the Blackland Prairie, to sandy soils of the Oak Woodlands. Mapped Holocene alluvial soils series in the areas examined during these work authorizations include Austwell, Balsora, Bastrop, Bosque, Branyan, Brazoria, Bunyan, Clairemont, Colorado, Decordova, Deleon, Dev, Elandco, Energy, Frio, Gaddy, Gageby, Gowen, Gowker, Hatliff, Lincoln, Meguin, Nahatche, Norwood, Nukrum, Oakalla, Ovan, Pledger, Pulexas, Pursley, Sagerton, Seguin, Spur, Tinn, Trinity, Uhland, Venus, Whitesboro, Yahola, and Yomont (see Table 1). Upland and old terrace soils in these areas include Abilene, Acme, Acuff, Aledo, Altoga, Amarillo, Arenosa, Austin, Axtell, Bastsil, Bernard, Bleiblerville, Bolar, Boonville, Brackett, Bremond, Brownfield, Burleson, Carbengle, Chaney, Chazos, Clodine, Cottonwood, Crockett, Crowley, Culp, Cuthbert, Denhawken, Denton, Doss, Dubina, Duffau, Eckrant, Eddy, Edna, Elmendorf, Eufaula, Fairly, Ferris, Frelsburg, Georgetown, Gruene, Hallettsville, Hearne, Heiden, Hensley, Hockley, Houston Black, Inez, Katy, Kaufman, Keese, Keeter, Klump, Krum, Laewest, Lake Charles, Latium, Latom, Leeray, Lewisville, Lott, Lufkin, Lupe, Mabank, Mansker, McLennan, Miles, Miller, Minwells, Nebgen, Nimrod, Nobscot, Owens, Padina, Paducah, Palopinto, Patilo, Pedernales, Pickton, Purves, Queeny, Quinlan, Rader, Real, Rioconcho, Robco, Rotan, Rowena, Sanger, Silstid, Slidell, Somervell, Speck, Stephen, Stidham, Straber, Tabor, Tarrant, Throck, Topsey, Tremona, Weatherford, Wilson, Windthorst, Winters, Wolfpen, and Woodward.

Most of the Impact Evaluations and Surveys ( $\mathrm{n}=151)$ were in rural areas where adjoining lands were undeveloped and usually in pastures, agricultural fields, or woods (see Table 1). Eighteen projects were in settings that can be classified as semirural (i.e., largely undeveloped but near low-density residential or commercial ar- eas) or semiurban (i.e., denser residential or commercial development). Thirteen project areas were in urban settings (i.e., the communities of Abilene, Albany, Belton, Georgetown, Gonzales, Grapevine, Hawley, Ranger, Salado, Smithville, Waco, Weatherford, and Wimberley).

\section{IMPACTS AND SITE POTENTIAL}

A primary thrust of the Surveys and especially the Impact Evaluations performed under this contract was documentation of existing disturbances that would affect the potential of each project area to contain archeological sites with sufficient integrity to be eligible for listing in the National Register of Historic Places or designation as State Archeological Landmarks. In general, four kinds of disturbances were observed consistently within existing rights of way: fill sections, ditches, gullies, and underground utilities (Figure 5).

Fill sections to elevate the approaches to bridges above the adjoining floodplains were present at 125 , or 69 percent, of the areas in which surveys or impact evaluations were done (Table 2). These fill sections ranged from $0.2 \mathrm{~m}$ thick to as much as $10 \mathrm{~m}$. Horizontally, they extended as little as a few meters from each end of a bridge to as much as several hundred meters, depending on the size of the valley and the kind of road. The higher and longer fill sections tended to be associated with the larger roads and larger streams. Typically, fill sections extended at least several meters beyond the edges of the pavement, in some cases occupying almost all of the existing right of way. It is difficult to quantify how much disturbance is associated with the placement of fill sections, but it is assumed that at least the upper $0.5 \mathrm{~m}$ of sediment beneath and beside fill sections is disturbed by heavy machinery during construction and later by compaction. Presumably, the larger the fill section, the deeper the disturbance.

In most cases, fill sections were bordered on both sides by shallow drainage ditches (see Table 2 ). These were found at 71 percent of the project areas. They usually were less than $1 \mathrm{~m}$ deep, and often less than $0.5 \mathrm{~m}$, and they were up to several meters wide. Vegetation covered most of them, and thus they did not offer any subsurface visibility, but some that recently had been maintained exposed subsurface deposits. In 


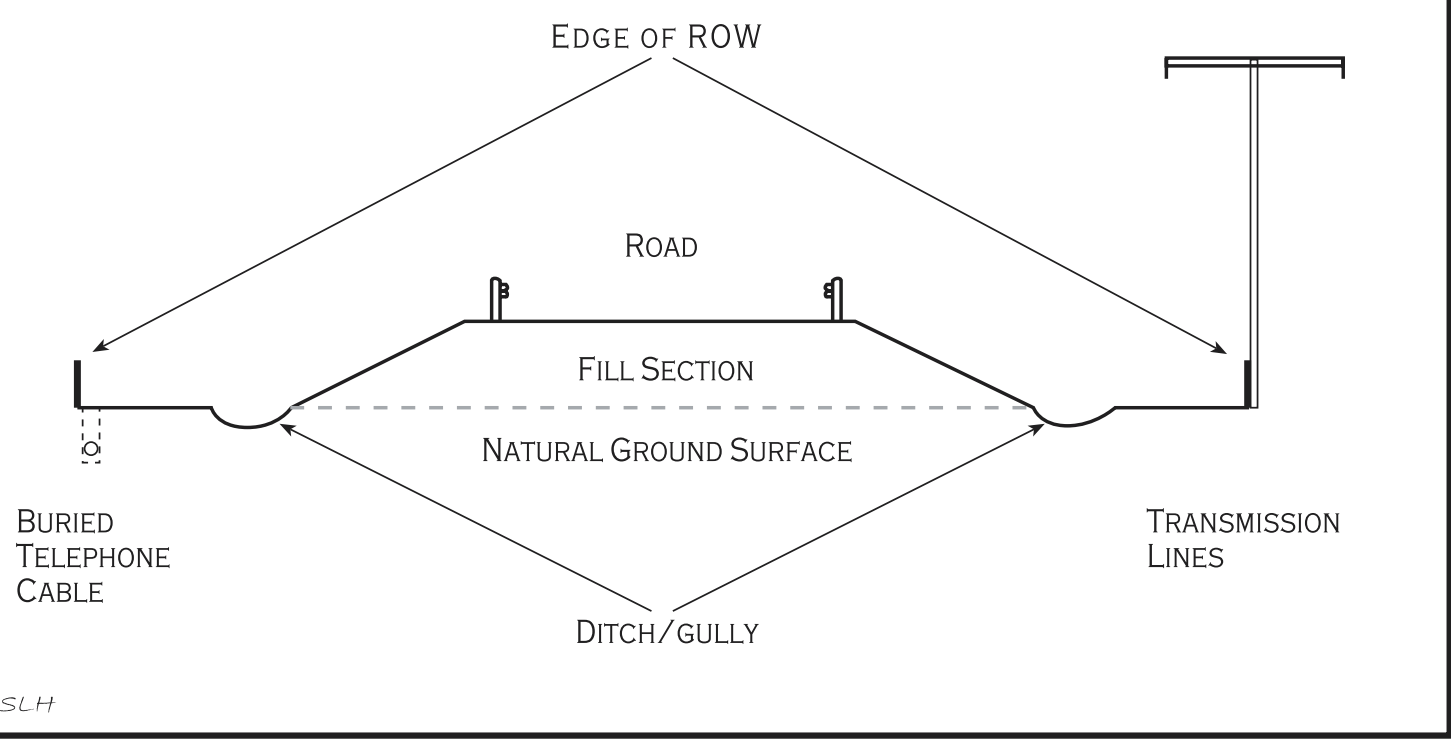

Figure 5. Schematic cross section of a bridge approach showing common disturbance factors.

some of the more-developed areas, the ditches were lined with concrete. Better exposures usually were provided by gully erosion, which occurred in 45 percent of the project areas. Gullying was observed often in the bottoms of ditches running along the edges of fill sections and breaching the creek banks. In many cases, such gullies were present at one or more corners of a bridge, often extending to depths of $1 \mathrm{~m}$ or more (see Table 2 ).

The fourth kind of disturbance observed consistently was underground utilities. These were present in many project areas, with the most common kind being buried telephone or fiber optic lines (see Table 2). These almost always were at one or both edges of the existing right of way and were marked by signs or areas of recent disturbance from placement of the lines. Based on the extent of the recent disturbance, it appears that trenching for these lines usually had disrupted an area $0.5 \mathrm{~m}$ or less in width, although vegetation grubbing and wheel rutting often had disturbed wider areas. Presumably, they vary in depth, with most probably being no deeper than $1 \mathrm{~m}$. More-extensive disturbance probably is associated with other kinds of underground utilities, including water lines, sewer lines, gas lines, and petroleum pipelines. These were not as ubiquitous as telephone and fiber optic lines, although some (especially water lines) may not be marked with signs as consistently as telephone and fiber optic lines.
Buried utility lines were observed at 61 percent of the project areas.

A variety of other disturbances were noted less frequently (see Table 2). These included the following: old road beds; flood scouring; construction of recreational facilities; adjacent railroad beds; two-track roads; road cuts; plowing; terracing; construction of berms; construction of driveways and other access roads; earthmoving; borrow pits; adjacent commercial and residential development; tree-removal pits; construction of stock tanks; deep tire ruts; creek channelization; levee construction; extensive sheet erosion; construction of low-water crossings; adjacent oil wells; fill placement; and grading. Sixty-one percent of the project areas had one or more of these kinds of disturbances. Overhead transmission and telephone lines, which were observed along the edges of the rights of way at many locations, occurred more frequently but caused little disturbance.

\section{SITES INVESTIGATED}

Forty-three archeological sites were investigated during 32 work authorizations. At 14 previously recorded sites, no archeological remains were observed. In all but 1 of these 14 cases, work was restricted to existing rights of way; in some, only general site locations were known, and the actual proximity of the sites to the Transportation Activities could not be 
Chapter 3: Summary

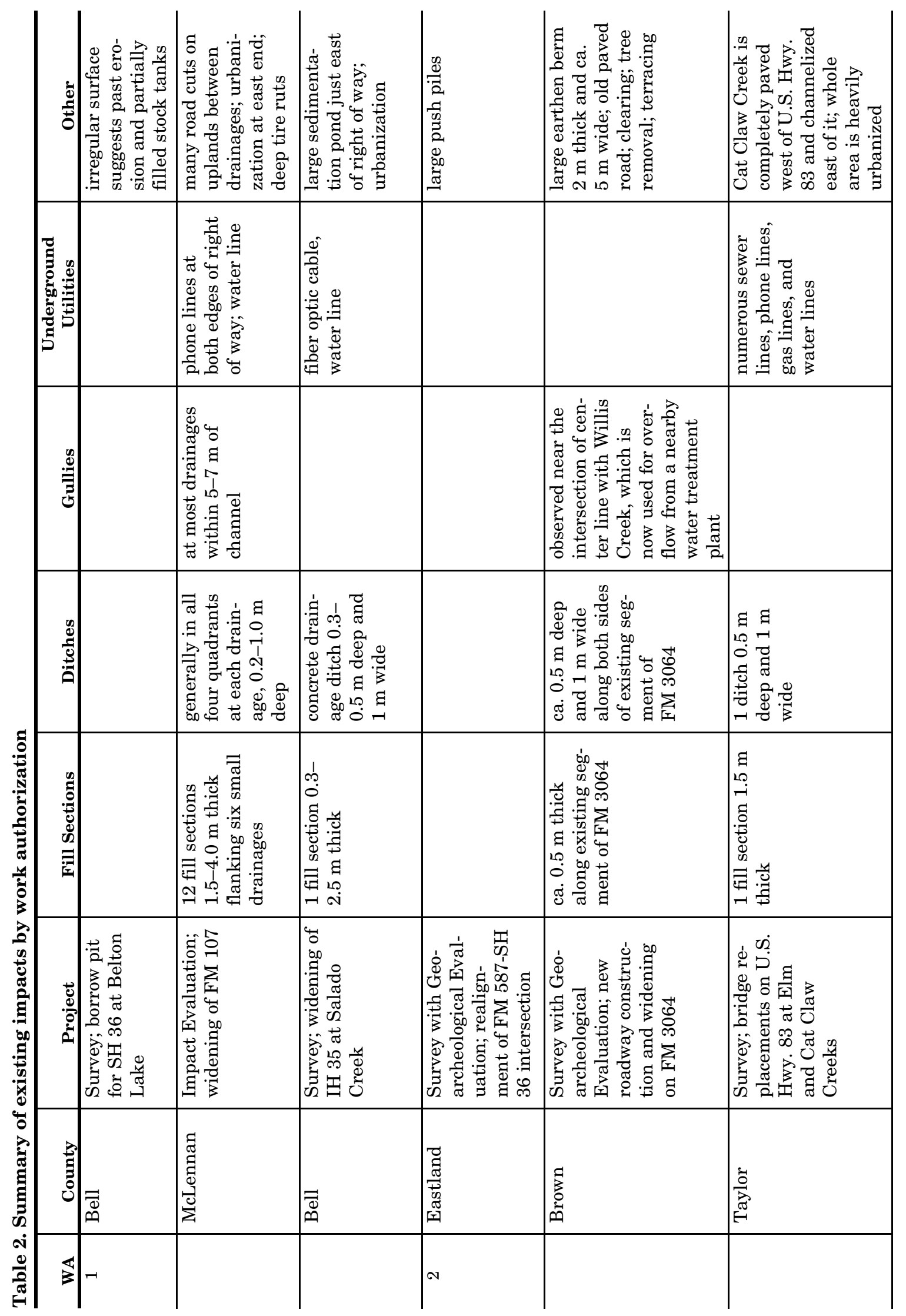


Archeological Impact Evaluations and Surveys

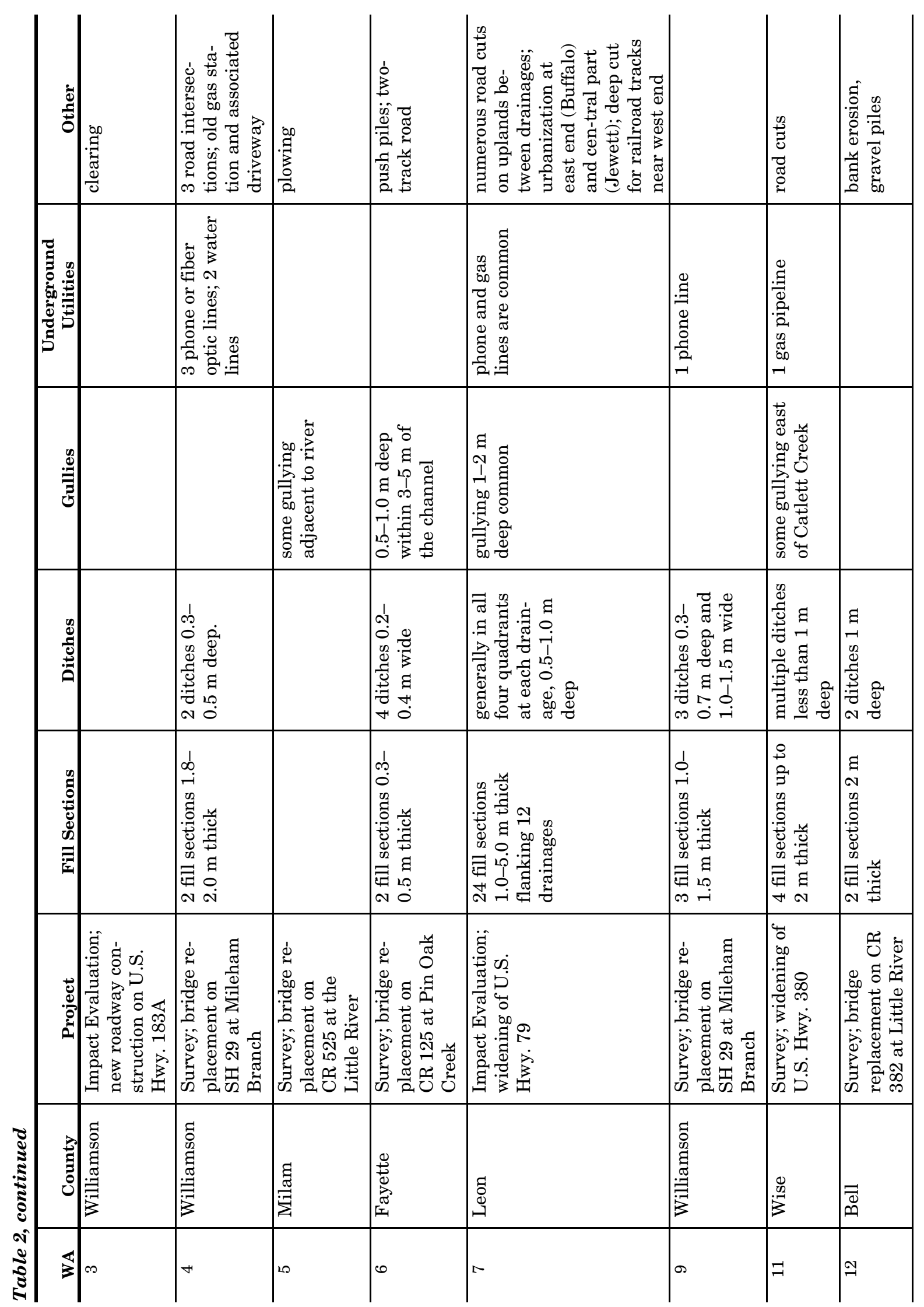


Chapter 3: Summary

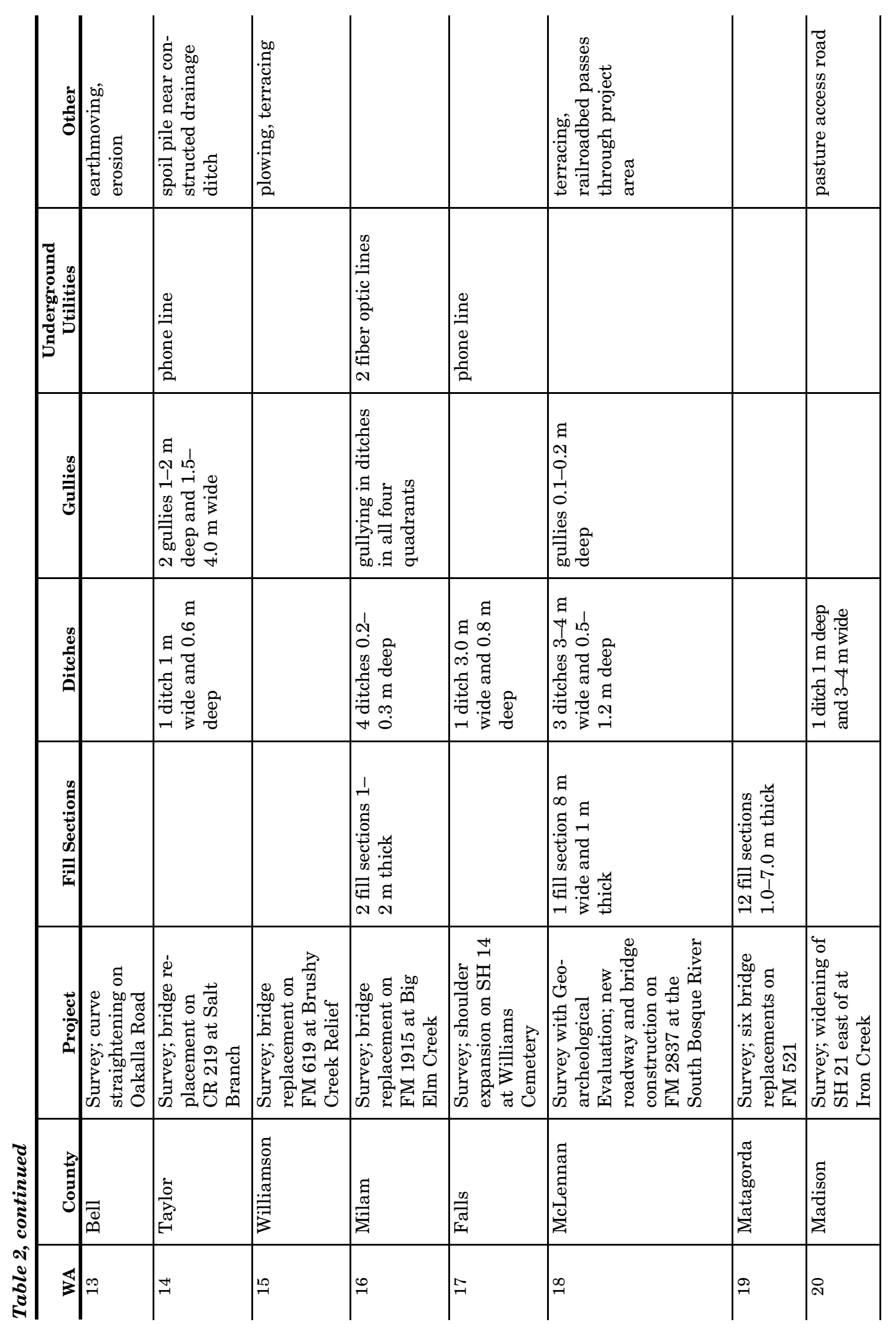


Archeological Impact Evaluations and Surveys

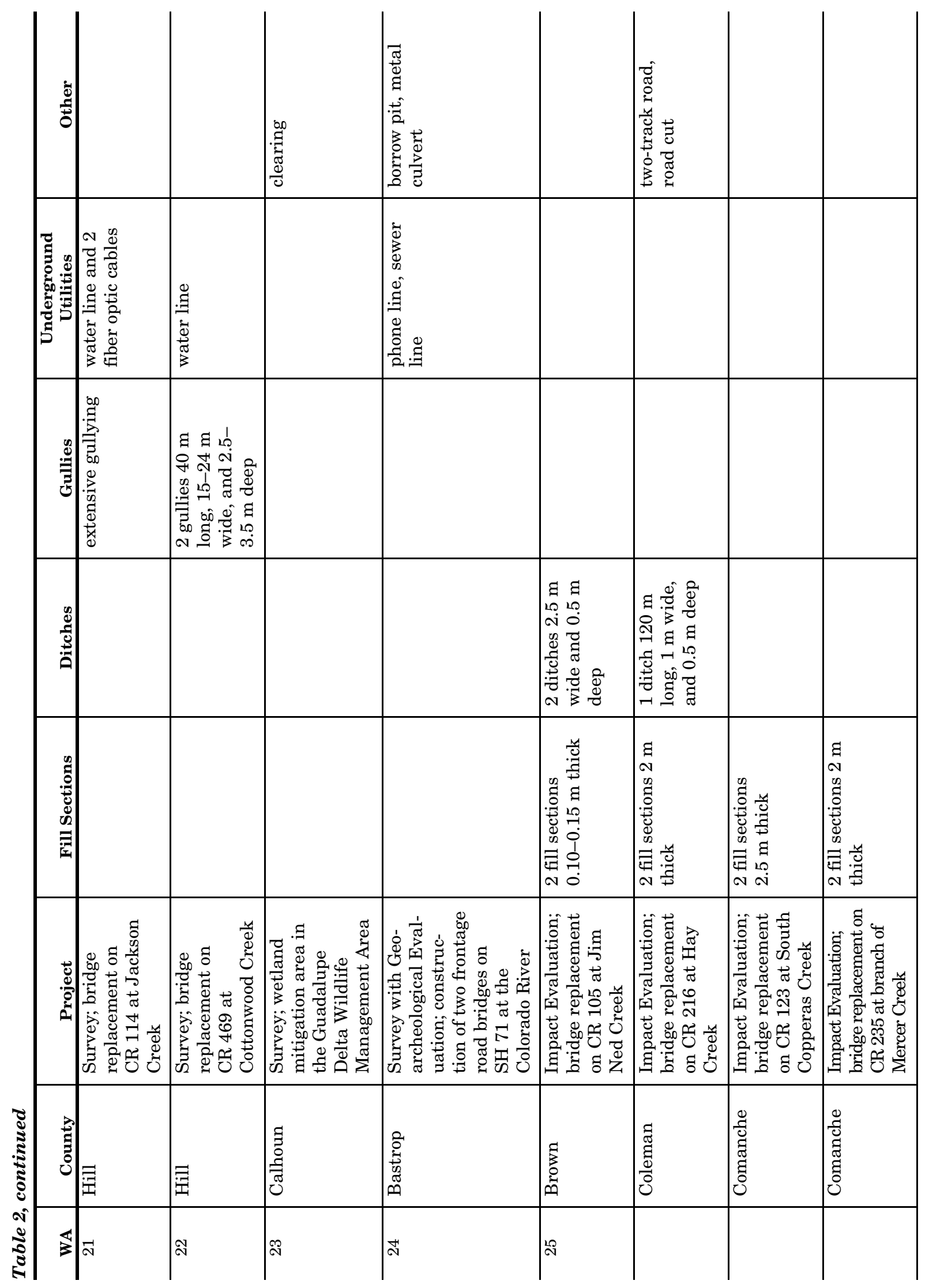




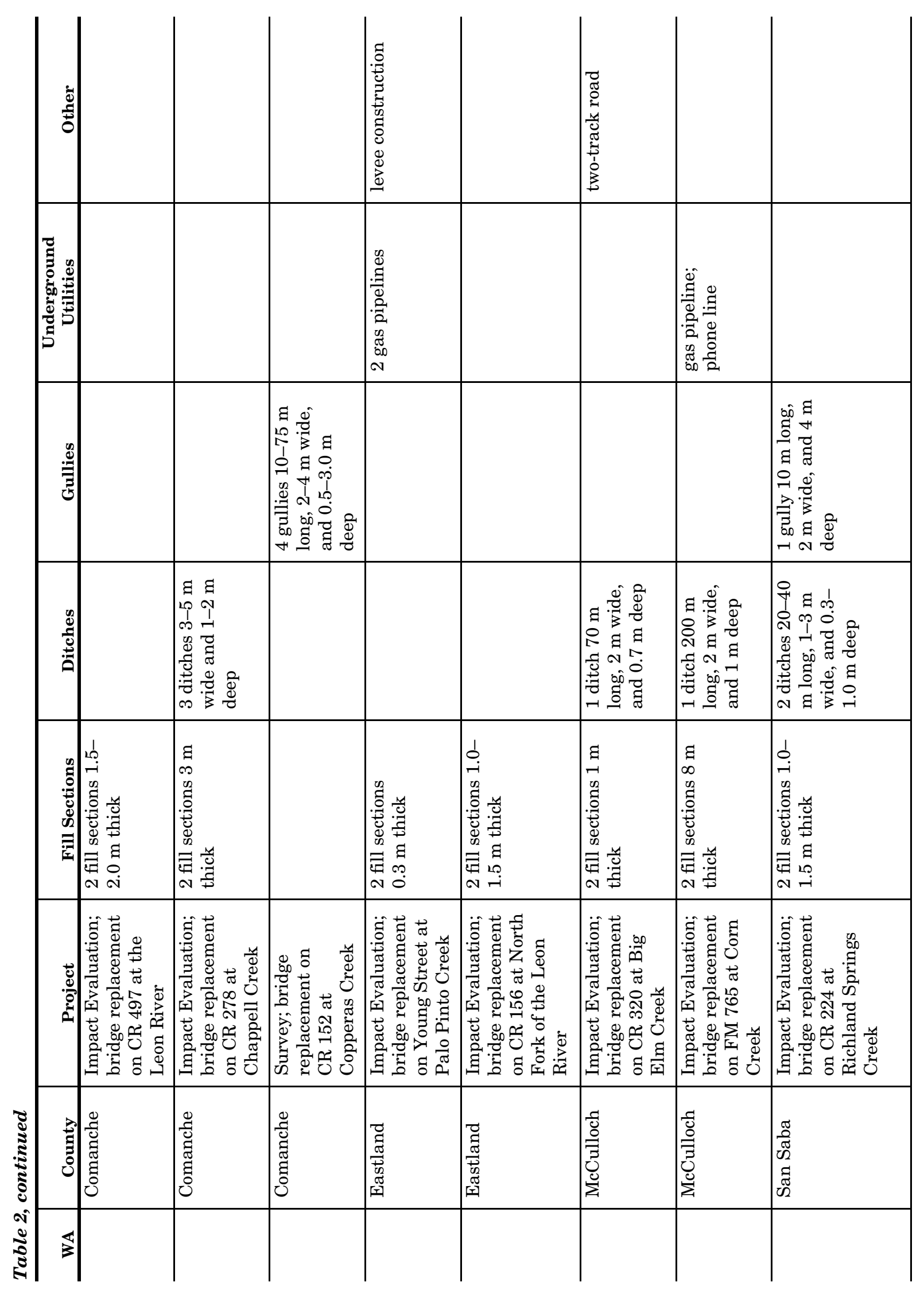


Archeological Impact Evaluations and Surveys

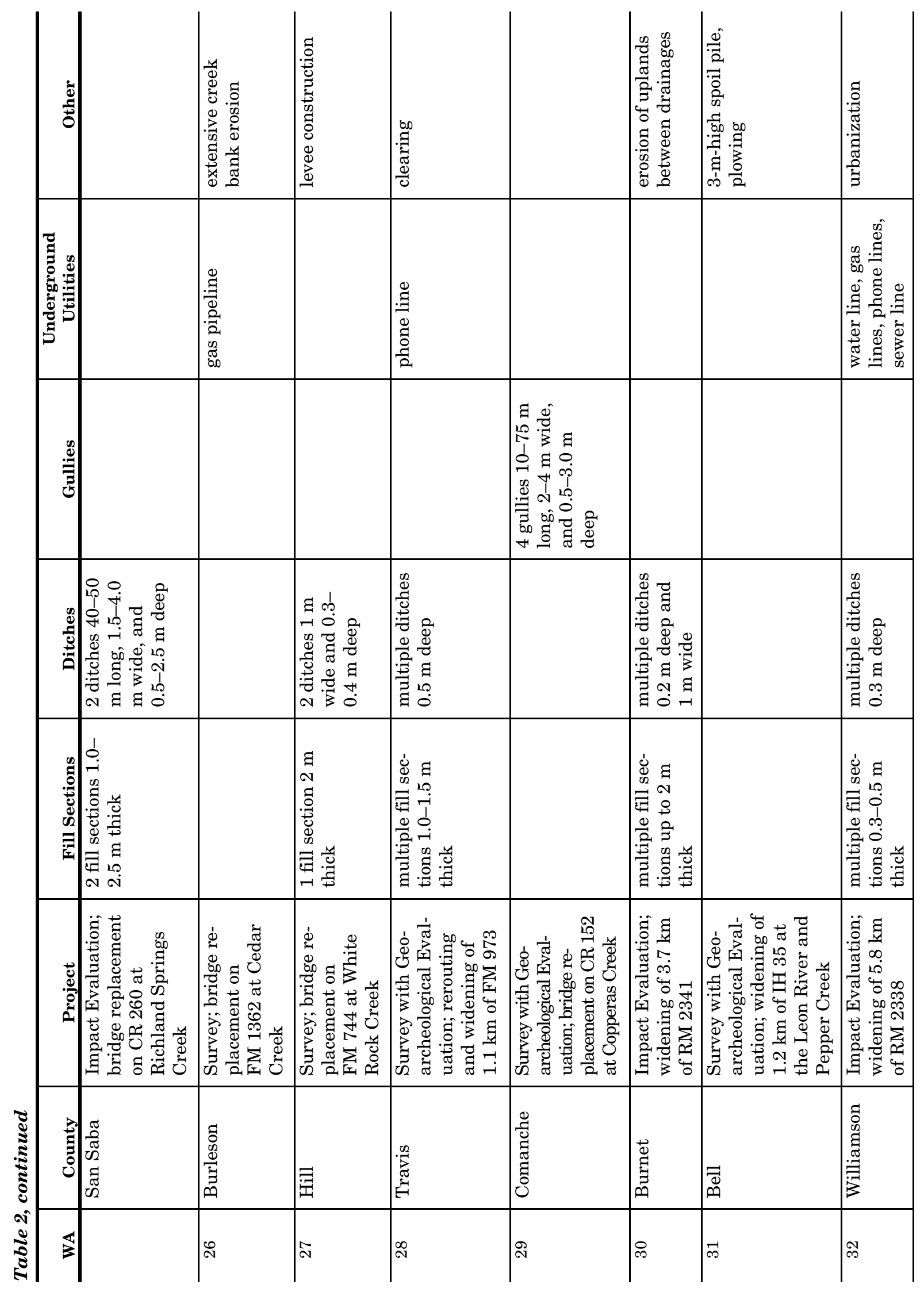




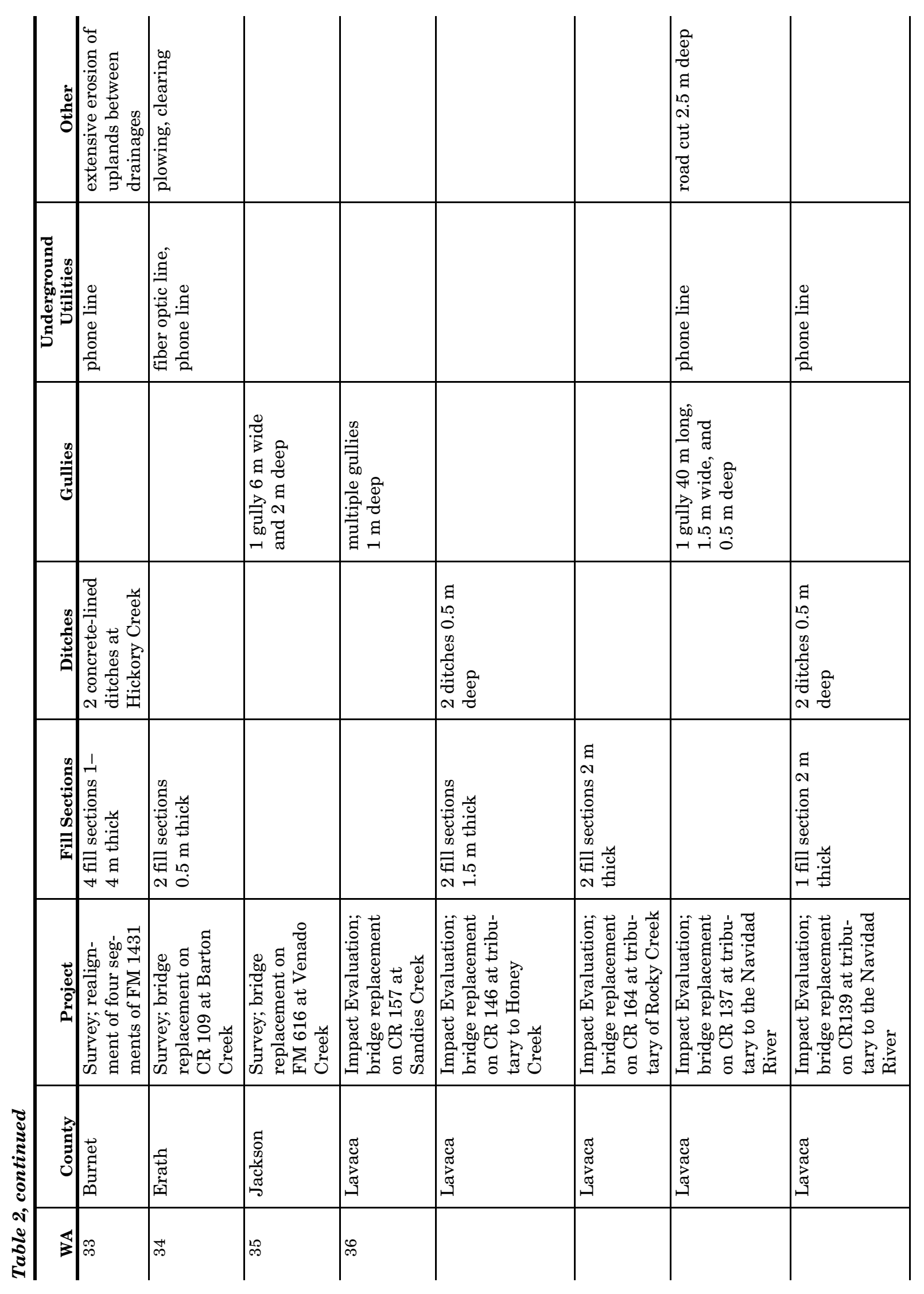


Archeological Impact Evaluations and Surveys

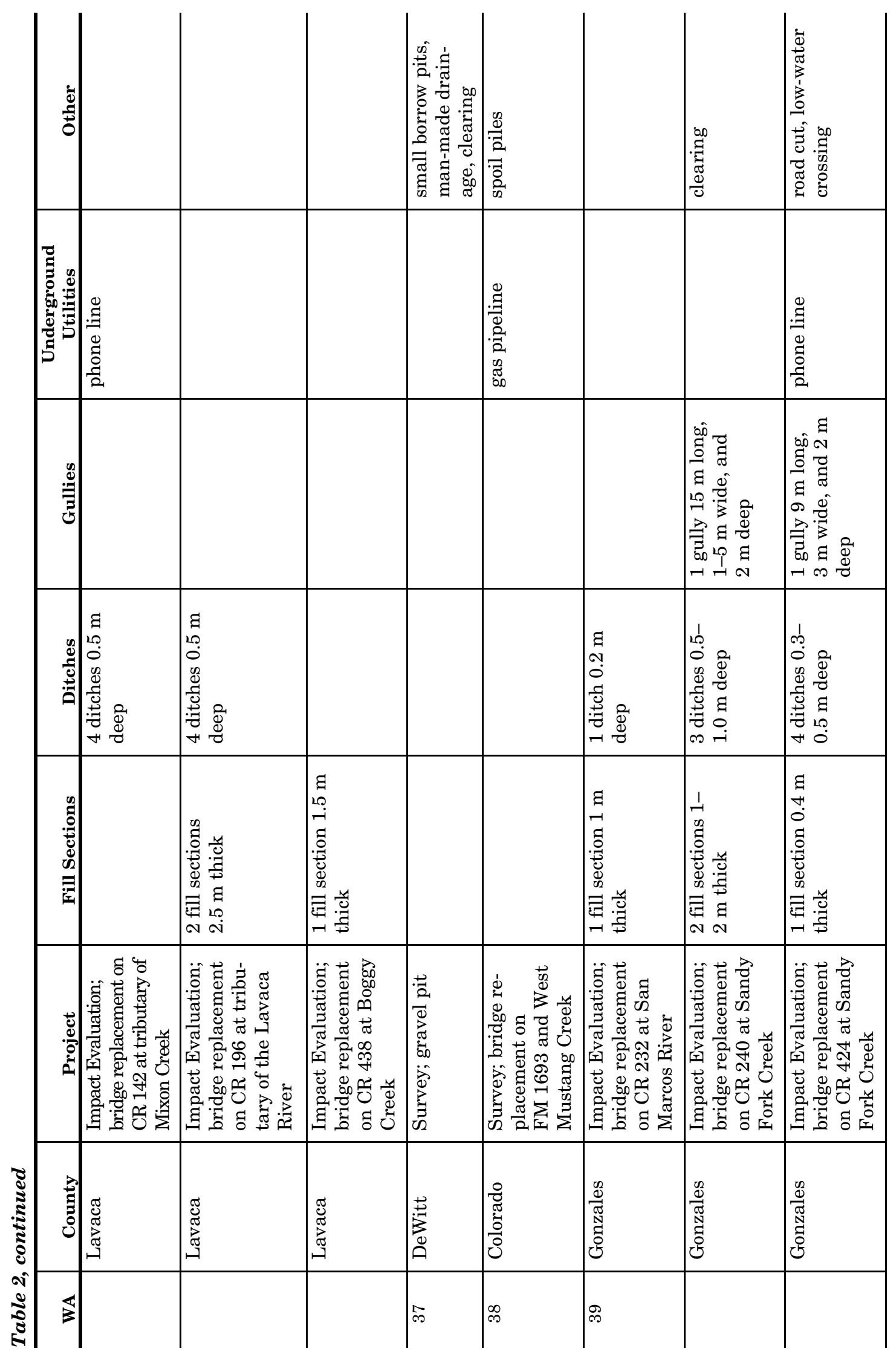




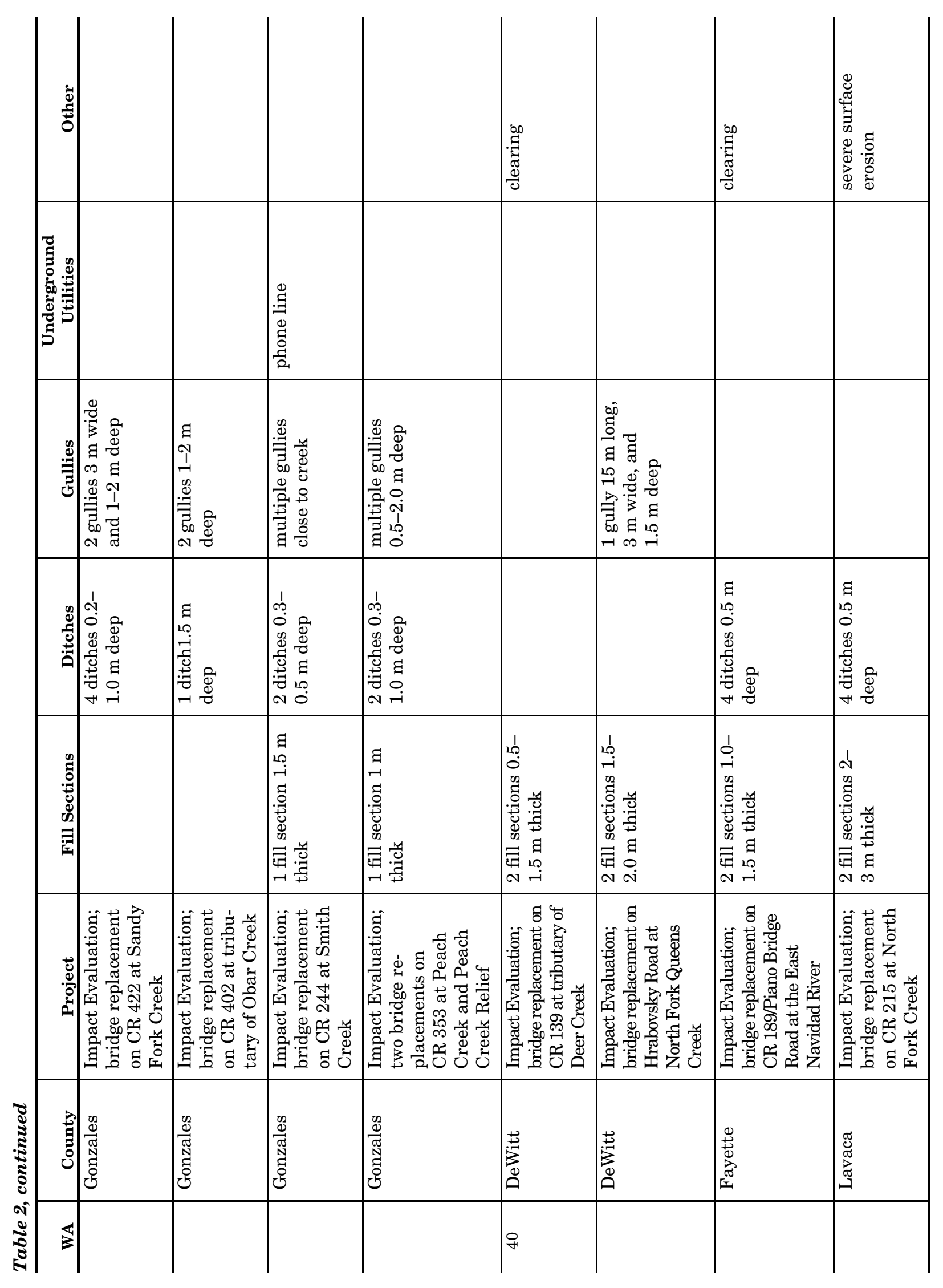


Archeological Impact Evaluations and Surveys

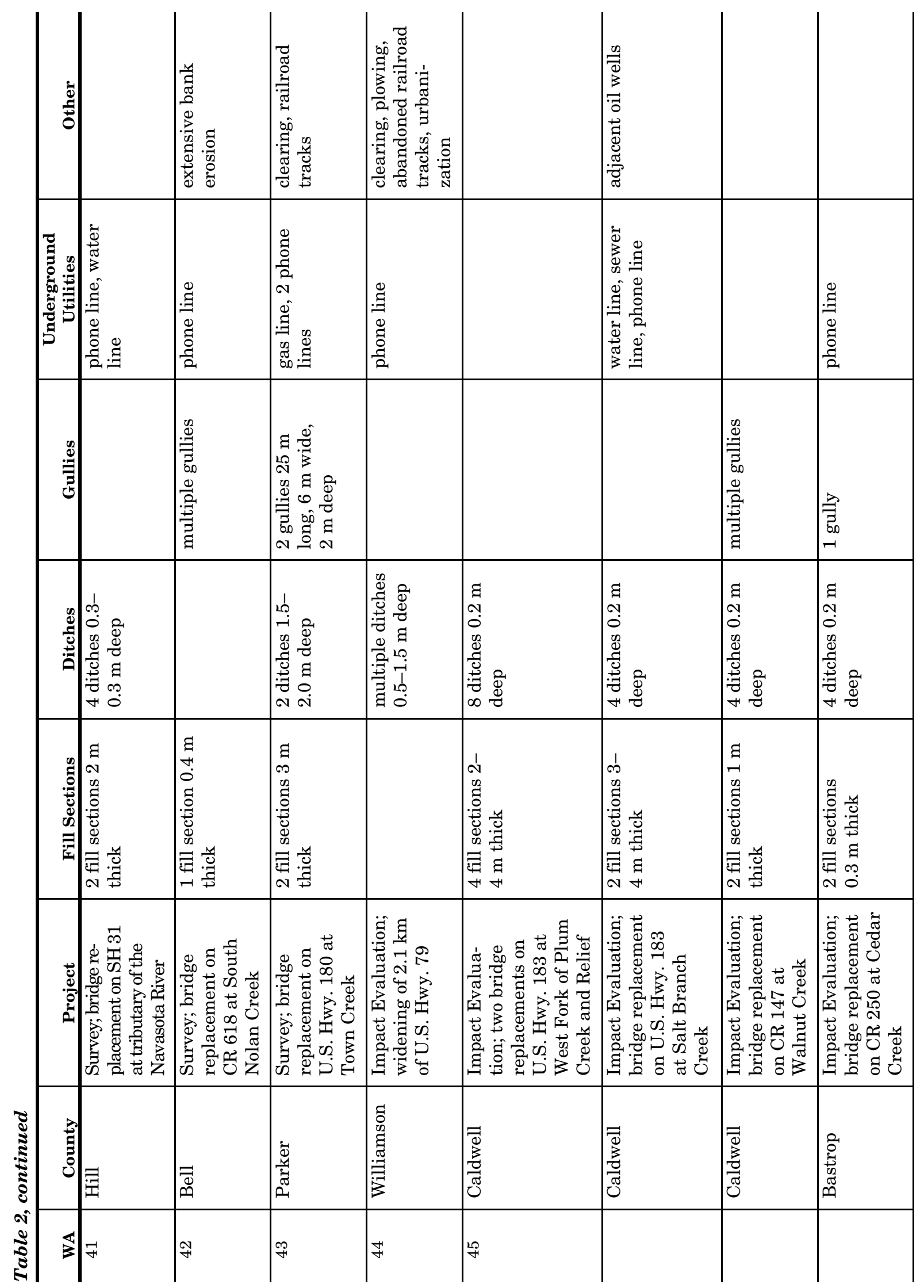


Chapter 3: Summary

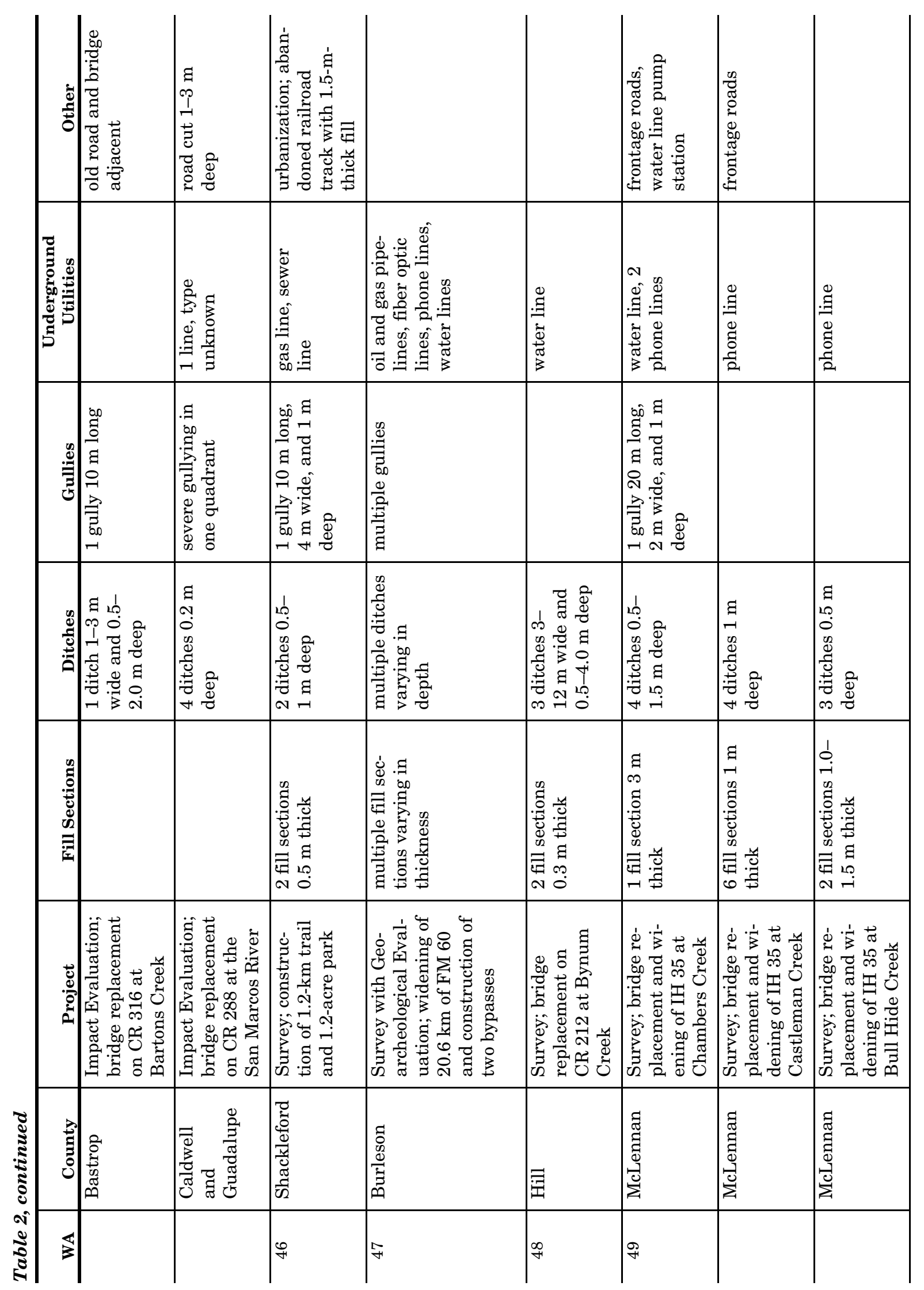


Archeological Impact Evaluations and Surveys

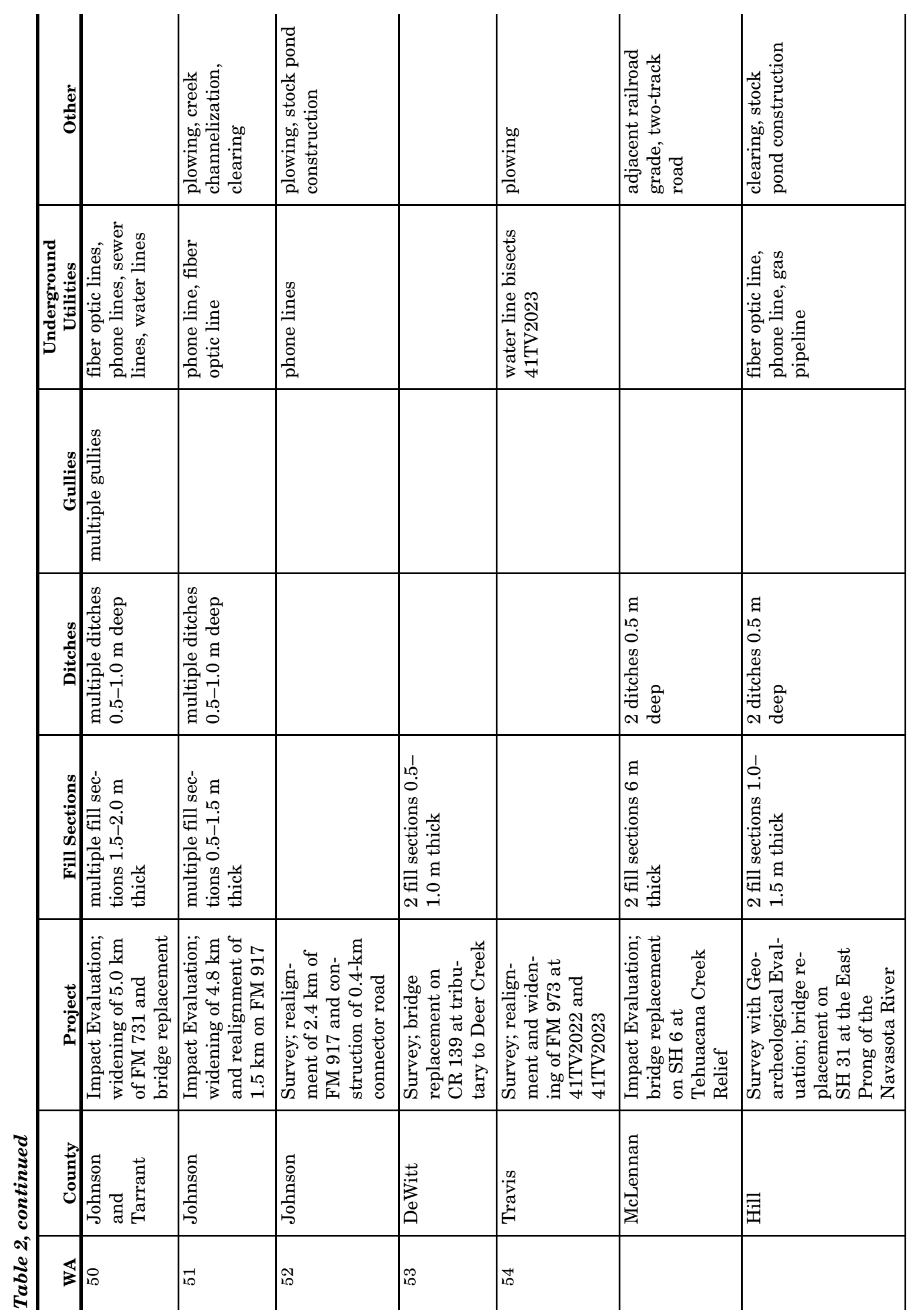


Chapter 3: Summary

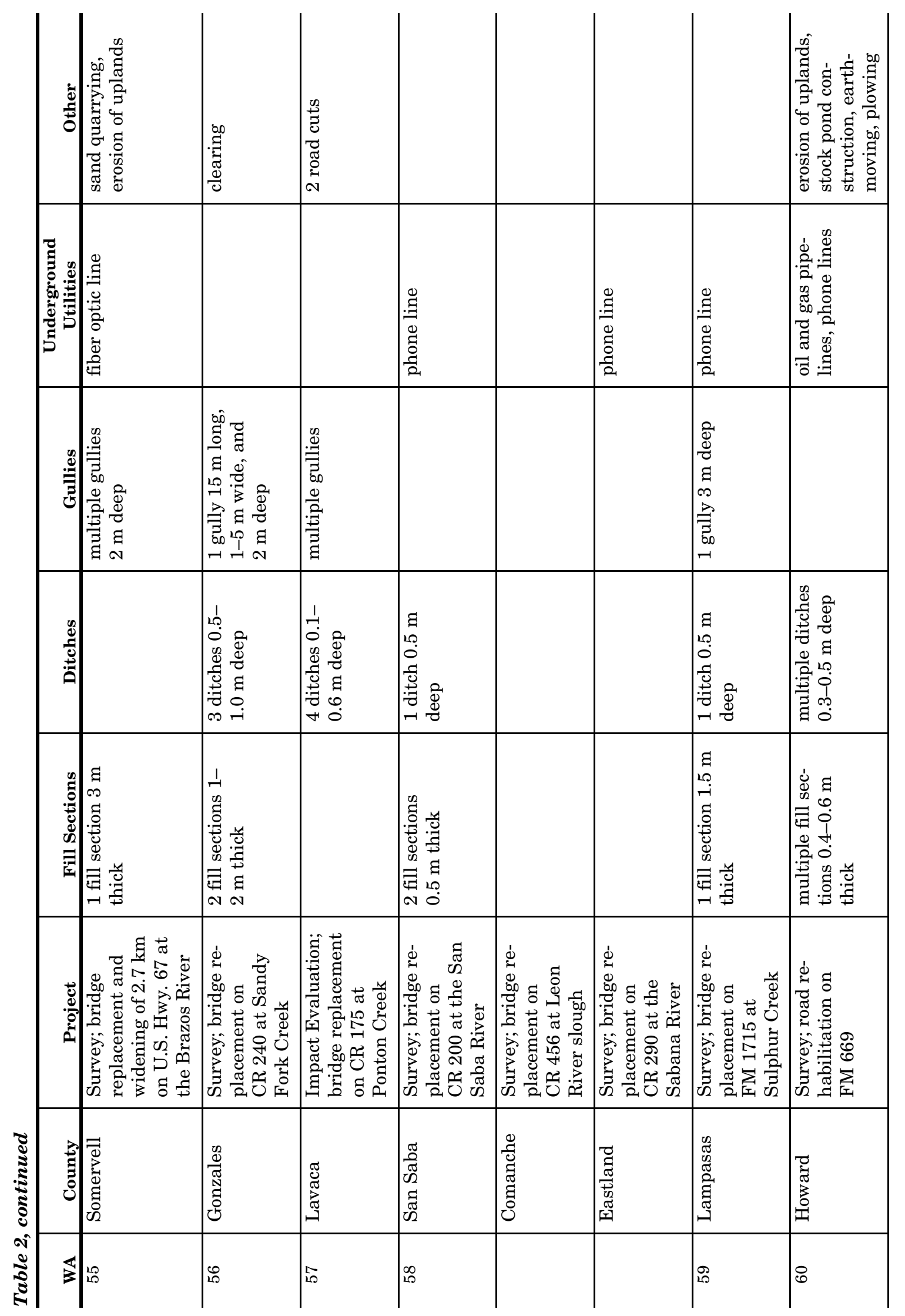




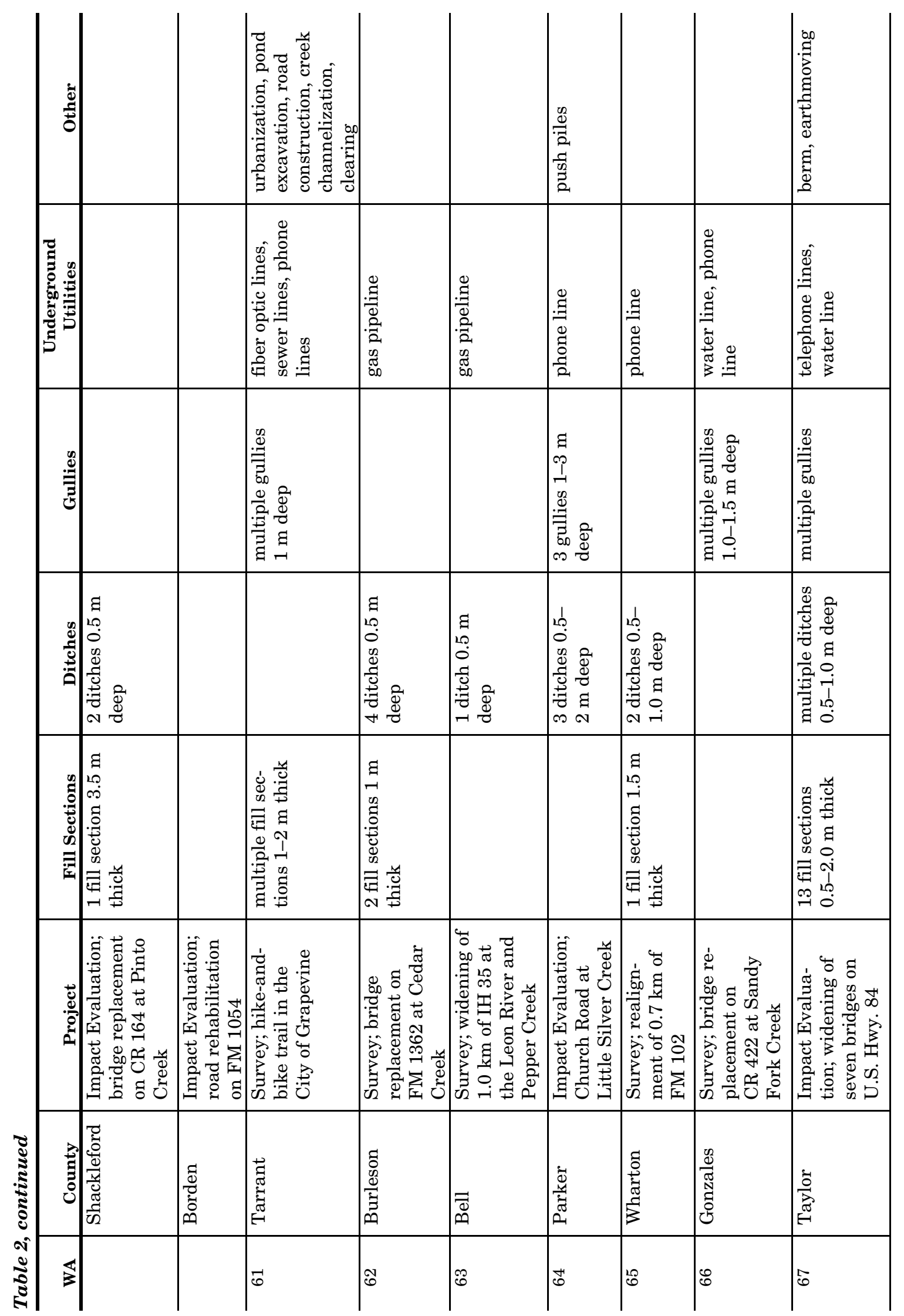


Chapter 3: Summary

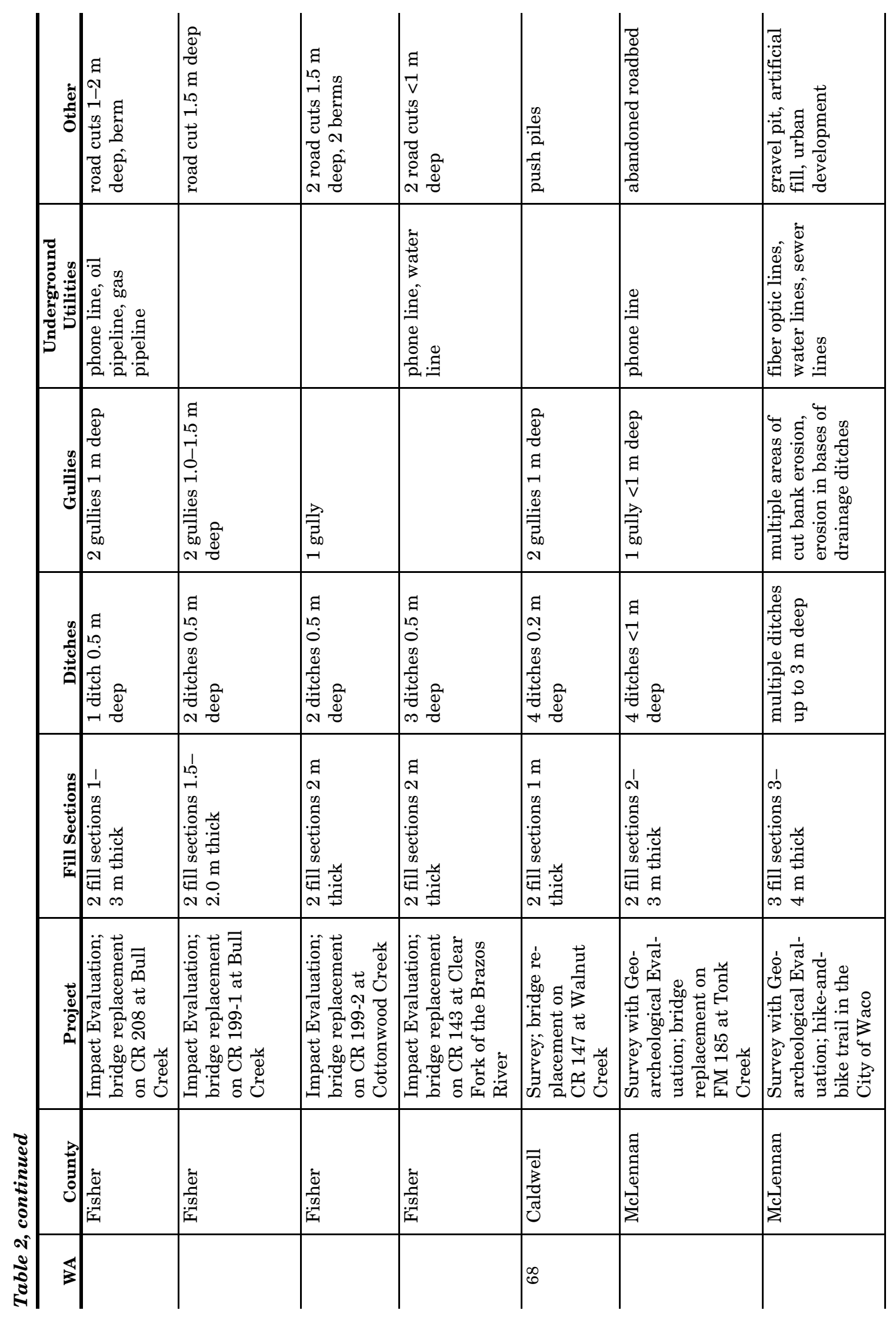


Archeological Impact Evaluations and Surveys

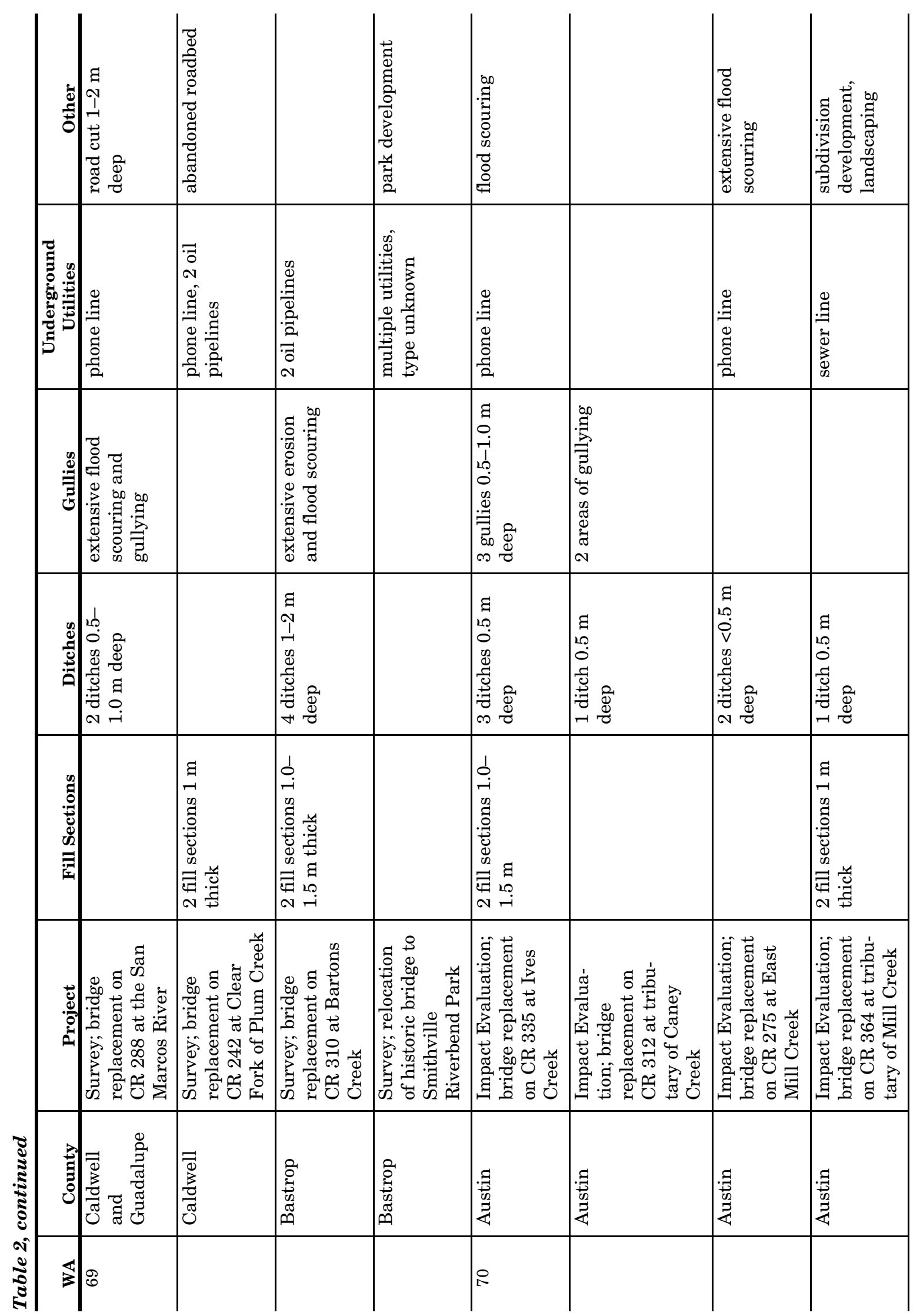


Chapter 3: Summary

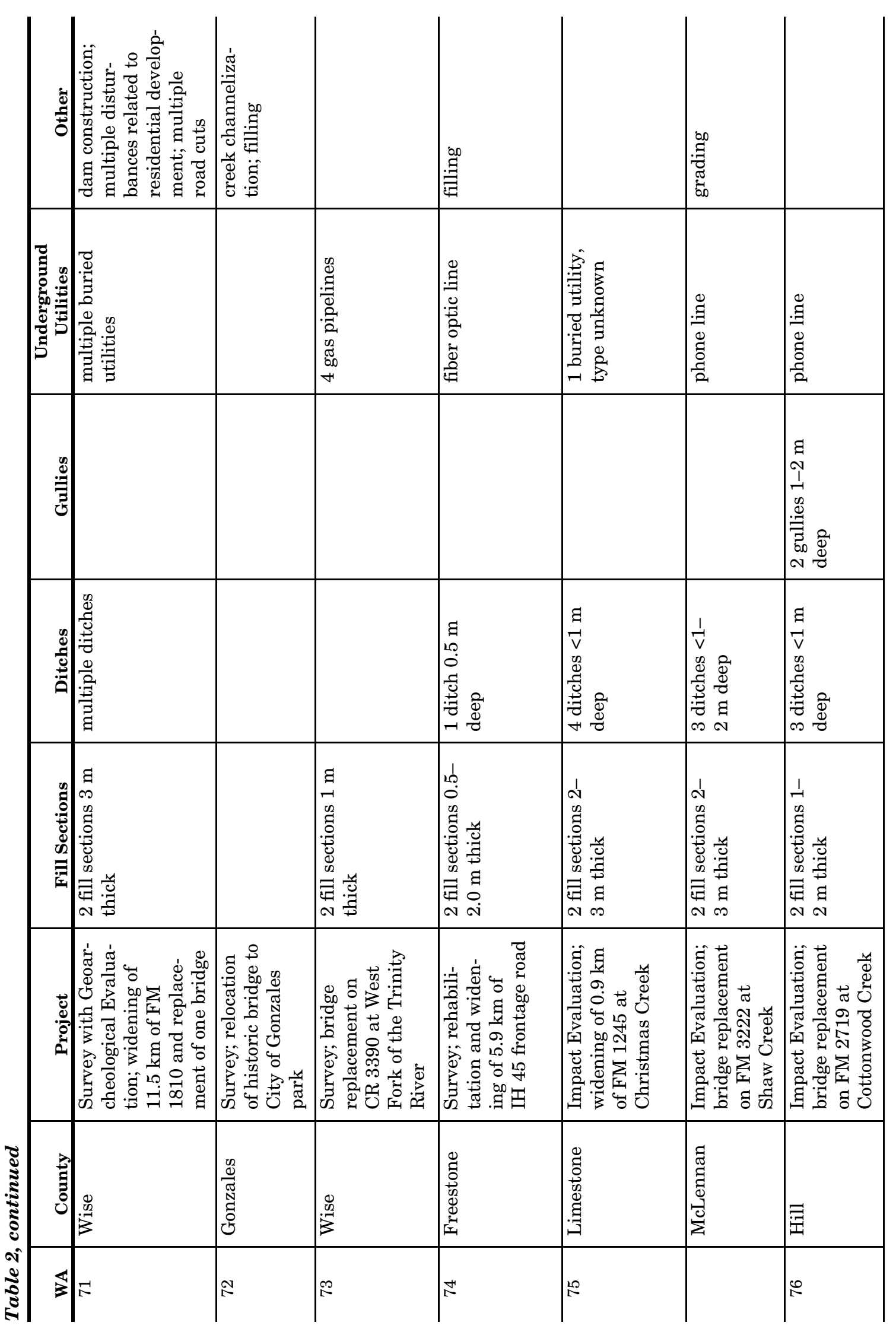




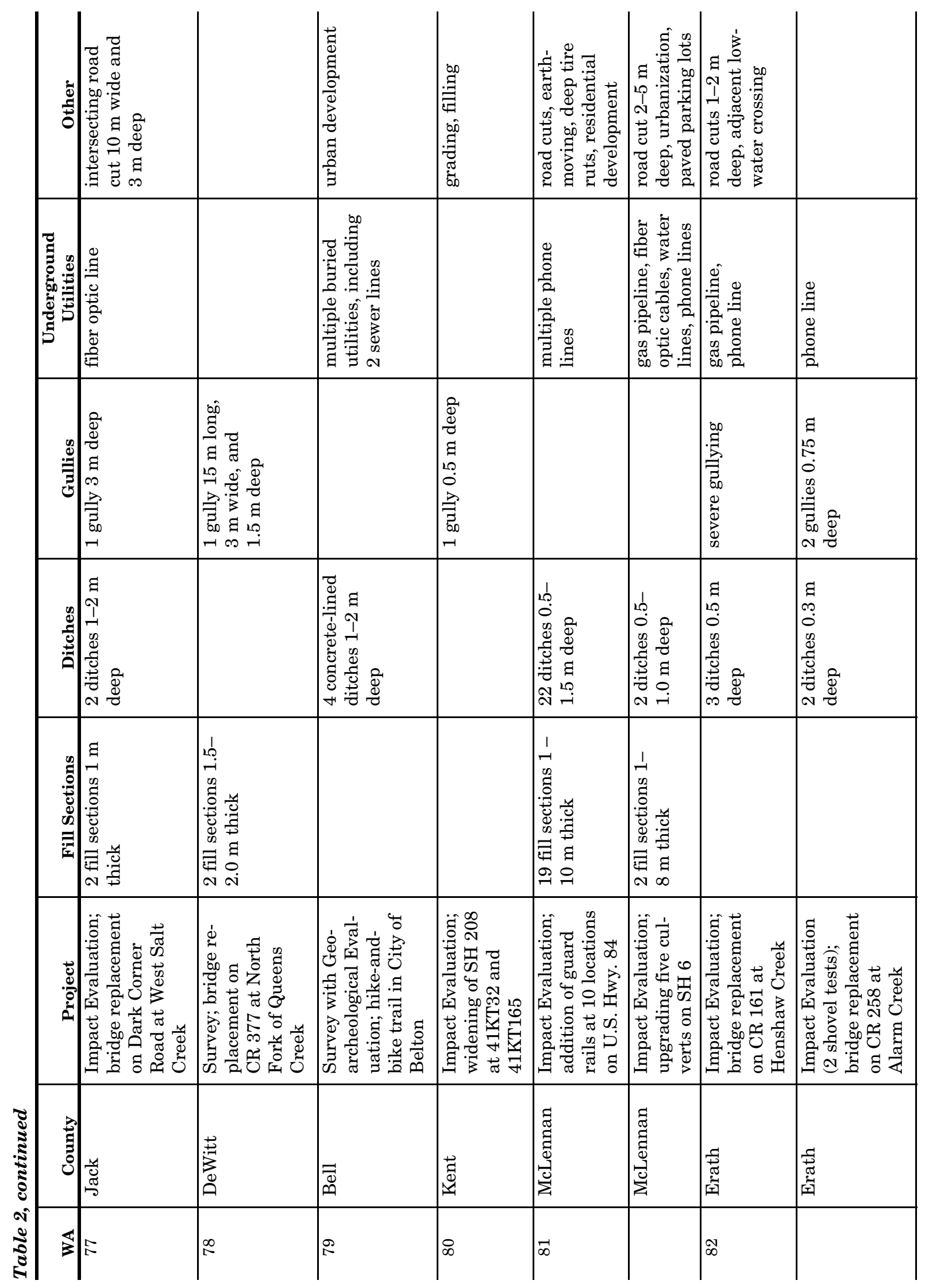


Chapter 3: Summary

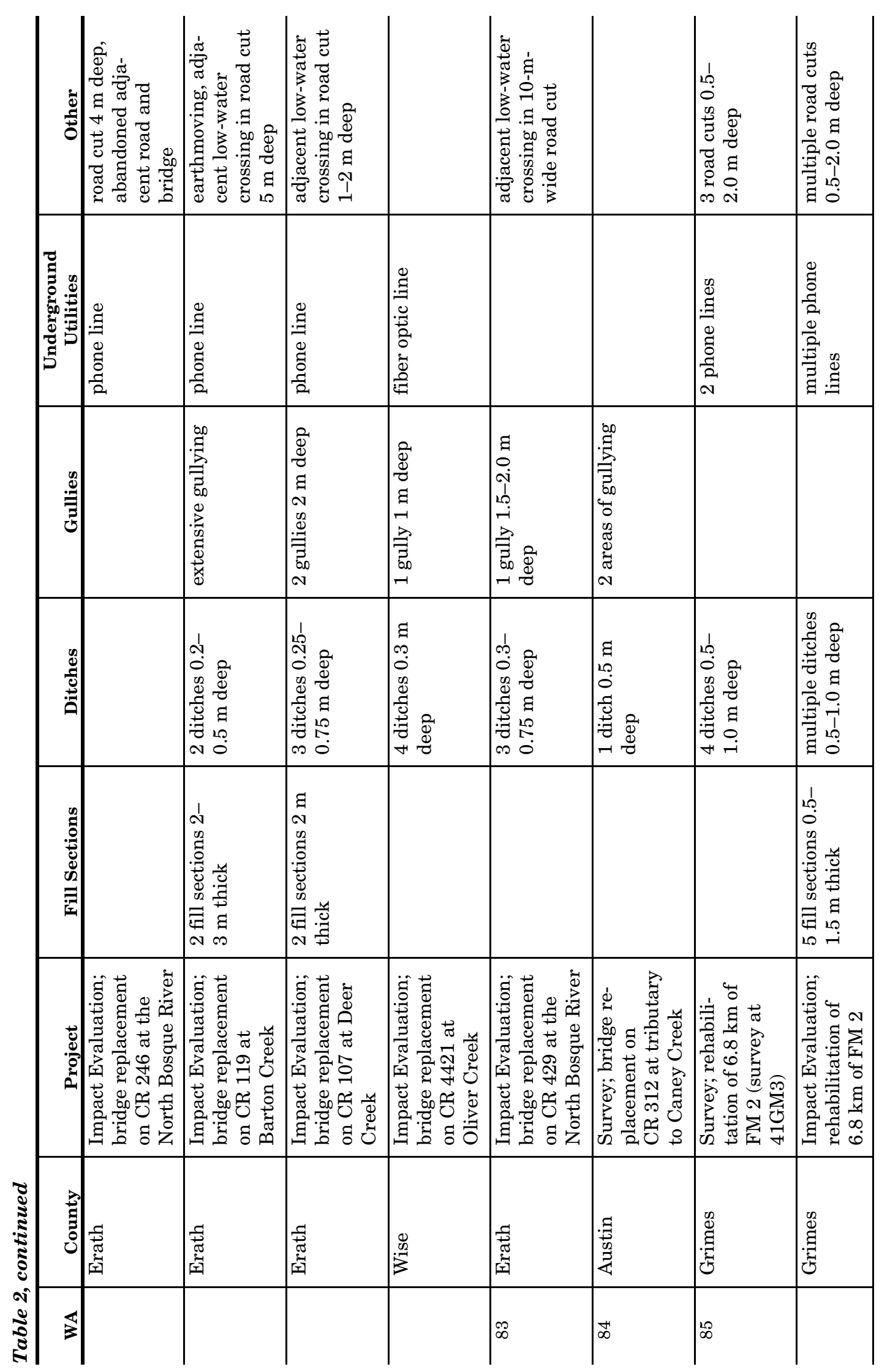


Archeological Impact Evaluations and Surveys

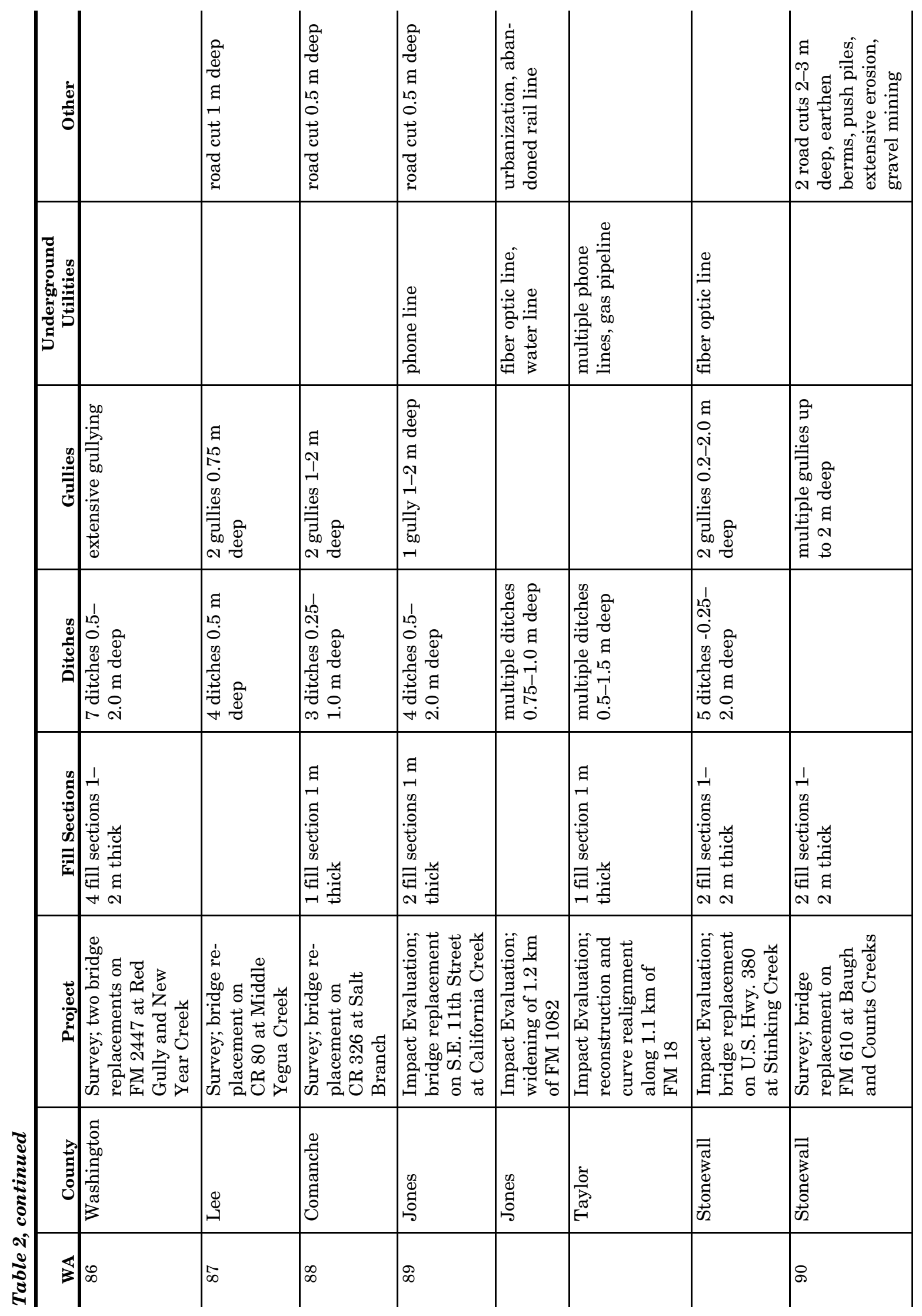


Chapter 3: Summary

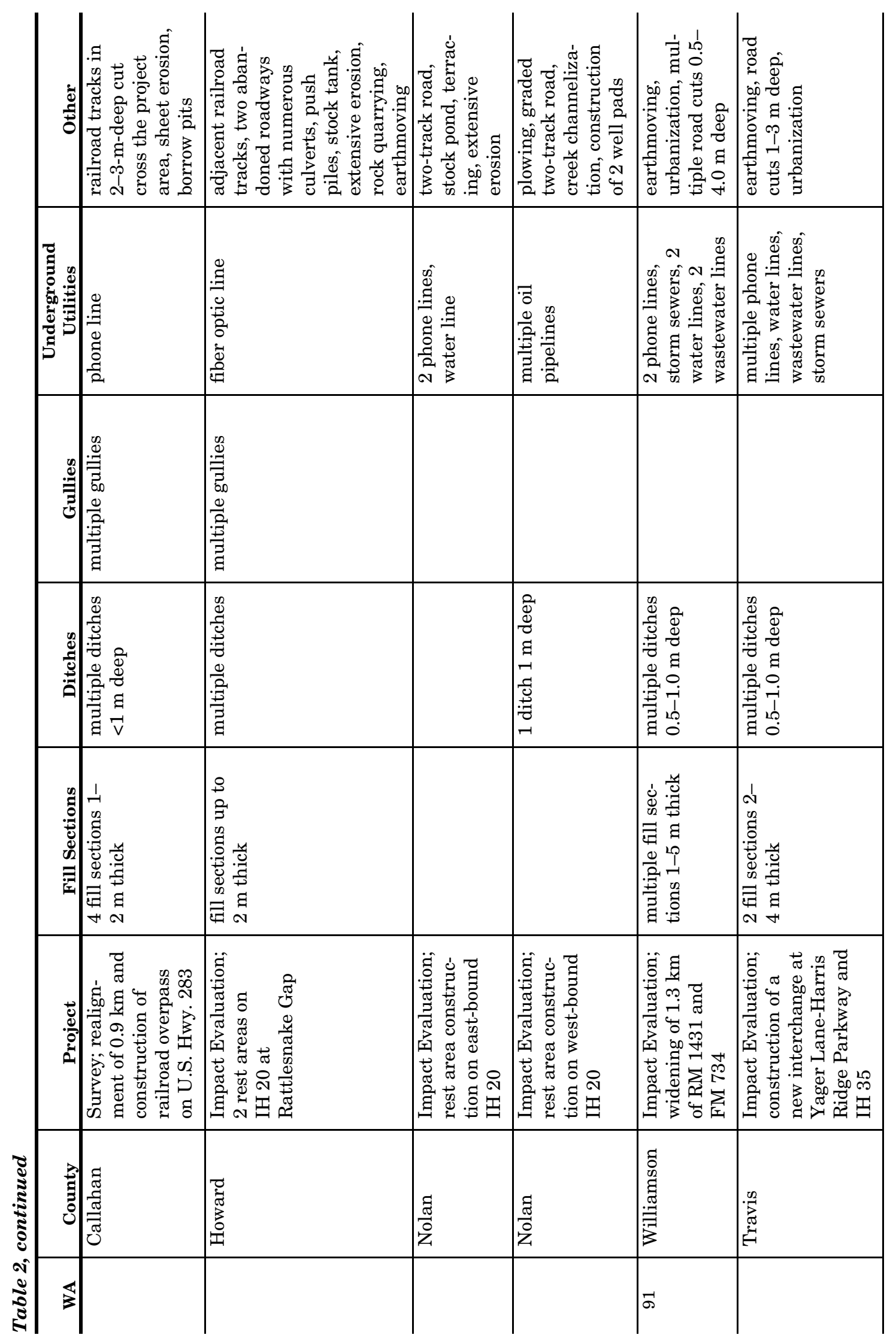


Archeological Impact Evaluations and Surveys

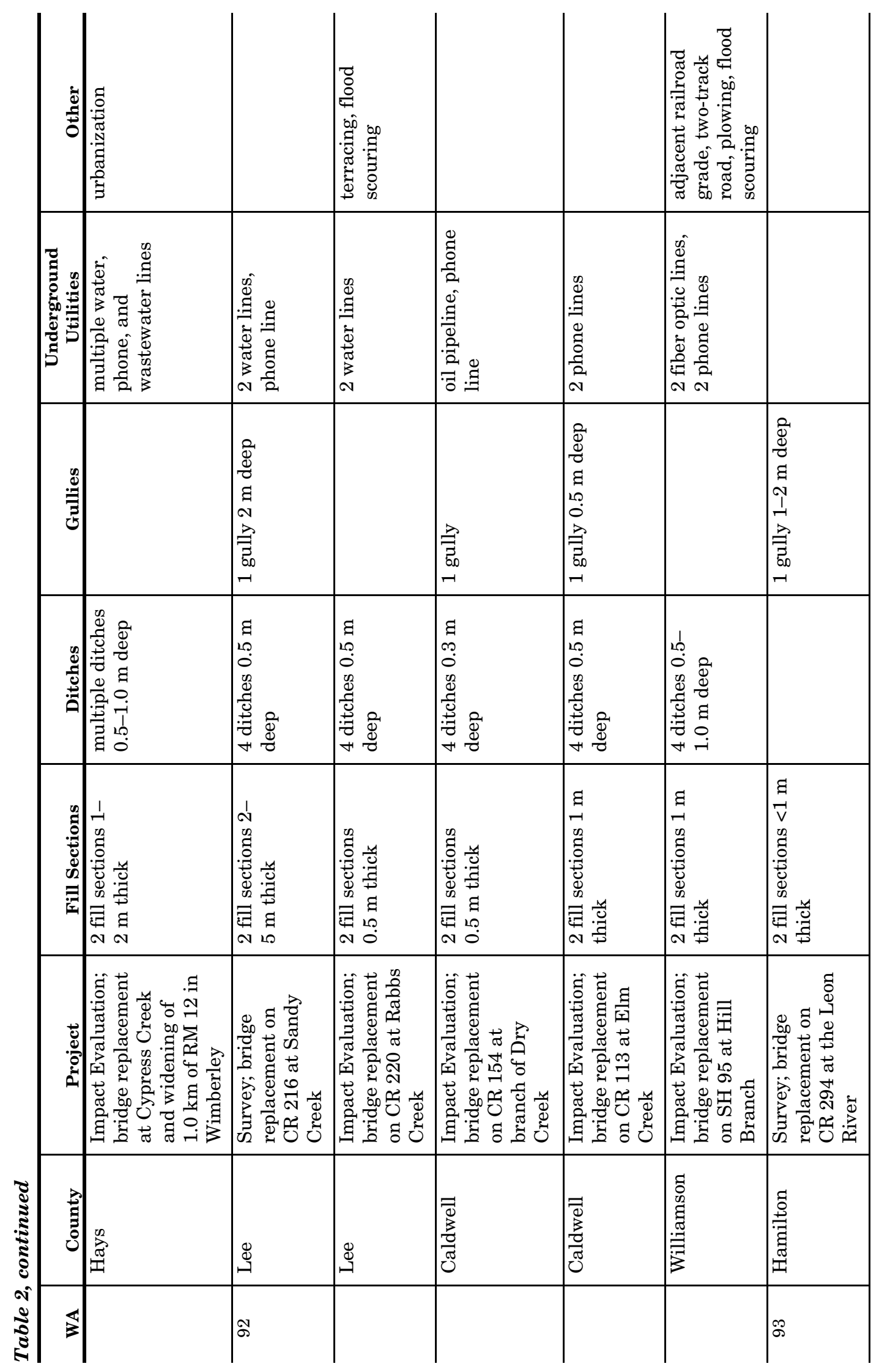


Chapter 3: Summary

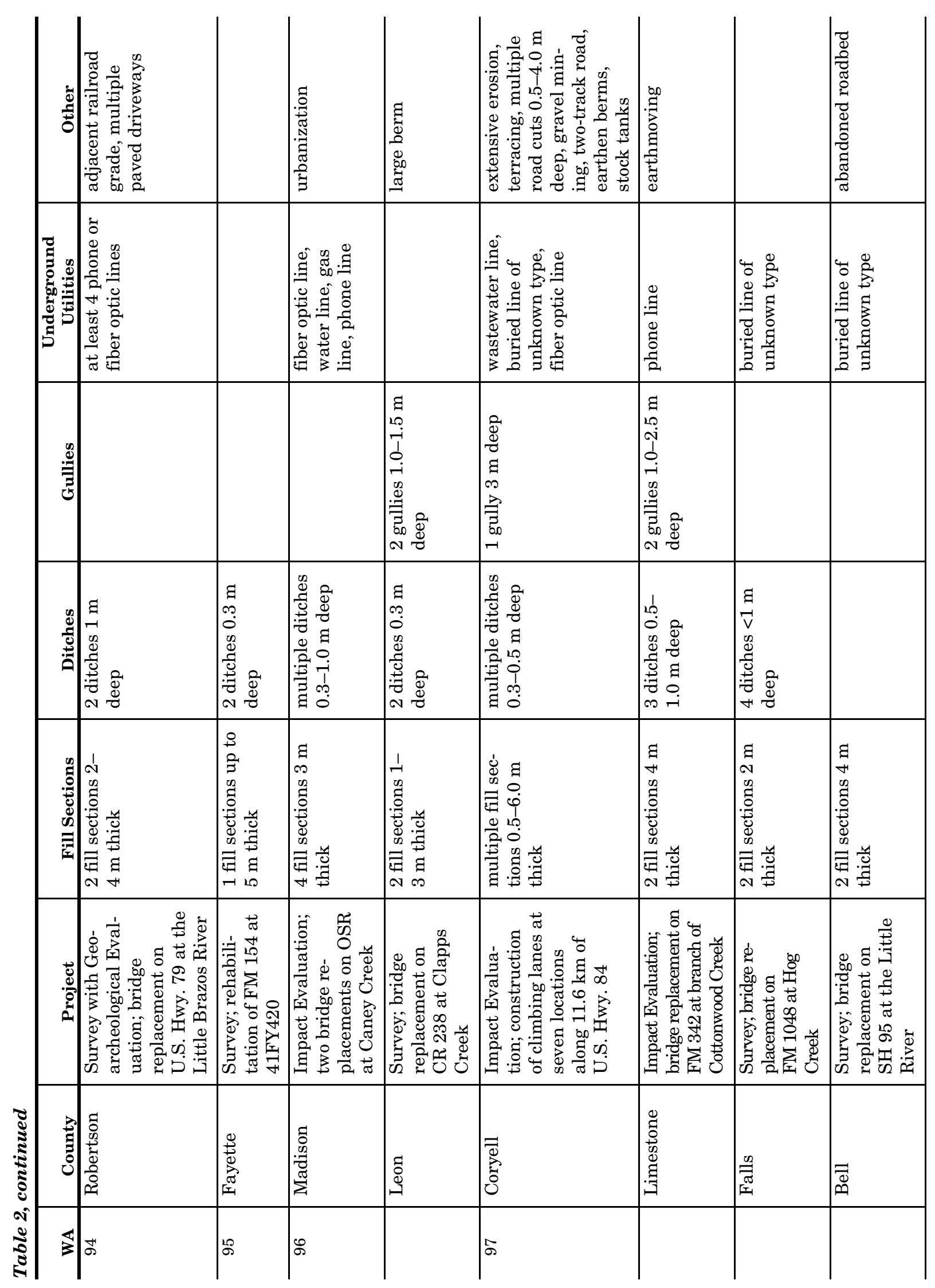


Archeological Impact Evaluations and Surveys

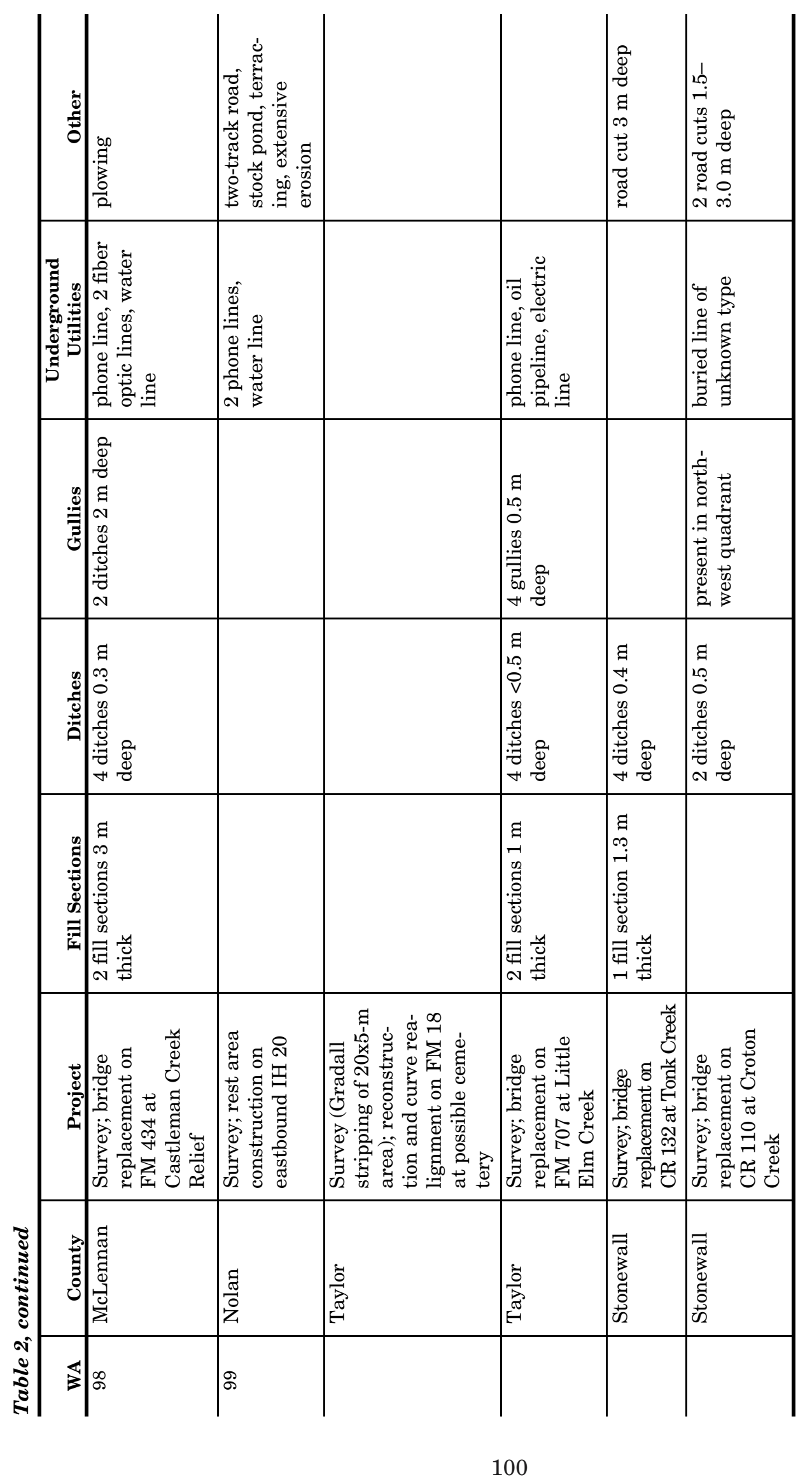


determined. Archeological remains were observed at the remaining 29 sites, sometimes in new right of way and sometimes in existing right of way. Descriptions of these sites, drawn from the original reports included on $\mathrm{CD}-\mathrm{ROM}$ in Appendix B, are presented below. Table 3 summarizes the materials observed and recommendations made. Also included are three cases in which historic-age features were investigated but not assigned trinomial designations.

\section{Work Authorization 3: 41WM646, 41WM1008, and $41 \mathrm{WM} 1009$}

One previously recorded site (41WM646) and two newly recorded sites (41WM1008 and 41WM1009) are within the parts of the proposed right of way of U.S. Highway 183A subjected to impact evaluation under Work Authorization 3. Chert flakes were noted on the surface between the center line and western boundary of the right of way in one location, and these artifacts appear to be the eastern extent of 41WM646, a lithic scatter covering an area of approximately 180x140 m (Voellinger 1985). Three shovel tests were excavated across the area of visible surface debitage. They were excavated to 5,15 , and $20 \mathrm{~cm}$ before encountering bedrock. No cultural materials were recovered. Another shovel test was excavated nearby to a depth of $8 \mathrm{~cm}$ before reaching bedrock. No cultural materials were recovered. The initial assessment of 41WM646 by Voellinger (1985) considered the site ineligible for listing in the National Register of Historic Places. Subsequent investigations conducted during this project concur with this assessment.

Sites 41WM1008 and 41WM1009 were found on gently sloping uplands dividing Spanish Oak and South Brushy Creeks. The first site, 41WM1008, consists of five pieces of chert debitage spread out over an area of ca. 30x30 m. No shovel testing was conducted because there was no soil. However, juniper needles and leaf litter made ground surface visibility ca. 50 percent, and some lithic artifacts were likely hidden from view. Site 41WM1009 consists of a surface scatter of lithic tools and debitage covering an area approximately $100 \mathrm{~m}$ north-south by 50 m east-west. During inspection of the area, one Angostura dart point was noted, as well as another untypeable (due to damage) dart point.
Approximately 30 pieces of lithic debitage were noted, many exhibiting a high degree of patination. Surface visibility ranged from 50 to 70 percent, and some artifacts were likely covered by leaf litter. No shovel testing was conducted due to the lack of soil. Due to the surface context of the scattered cultural materials at 41WM1008 and 41WM1009, both sites have no capacity to contain important information and are ineligible for listing in the National Register of Historic Places or designation as State Archeological Landmarks.

\section{Work Authorization 11: 41 WS56}

Site 41WS56 was identified in trenching proposed new right of way along the western alluvial terrace of Catlett Creek north of U.S. Highway 380. Six backhoe trenches were excavated across the terrace, but cultural materials were exposed only in Trench 3. All of the trenches exhibited similar stratigraphic profiles, and three general stratigraphic zones were observed. Zone 1 consists of a plow-disturbed dark grayish brown (10YR 4/2) sandy clay loam A horizon with an underlying $B$ horizon that extends from the surface to a depth of ca. $90 \mathrm{~cm}$. Zone 2 consists of a very dark gray (10YR 3/1) silty clay loam paleosol encountered from ca. 90 to $130 \mathrm{~cm}$, marked by a Bkb horizon. Zone 3 was encountered from 130 to $160 \mathrm{~cm}(220 \mathrm{~cm}$ in Trench 3 ) and consisted of a mottled dark grayish brown (10YR 4/2) and brown (10YR 5/3) silty clay loam BCkb horizon.

The archeological materials in Trench 3 (designated 41WS56) appear to be contained within the Zone 2 paleosol $(90-130 \mathrm{~cm})$. Cultural materials including charcoal, a burned rock, and a bone fragment were first observed in the backdirt. After the trench walls were cleaned and examined, two additional bone fragments, a burned rock, and scattered charcoal were observed. No cultural materials were noted either above or below Zone 2 . In all (including materials found in the backdirt), three long bone fragments (cf. white-tailed deer), one chert flake, copious wood charcoal, several small clumps of burned clay, one burned rock larger than $5 \mathrm{~cm}$, and five smaller burned rocks were observed. Trenches 5 and 6 were placed 30 m east and west of Trench 3 to define the extent of the cultural deposits. Although a few small pieces of charcoal were seen at $90-130 \mathrm{~cm}$ in Trench 5 , no 
Table 3. Summary of archeological sites investigated

\begin{tabular}{|c|c|c|c|}
\hline WA & Site & Materials Observed & Recommendation \\
\hline 3 & 41WM646 & debitage & no further work \\
\hline 3 & 41WM1008 & debitage & no further work \\
\hline 3 & 41WM1009 & debitage, Angostura dart point, untyped dart point & no further work \\
\hline 11 & 41WS56 & $\begin{array}{l}\text { debitage, burned rocks, animal bones, charcoal, burned } \\
\text { clay }\end{array}$ & test excavations \\
\hline 13 & 41BL1155 & historic-age house & no further work \\
\hline 17 & 41FA69 & historic-age cemetery & no further work \\
\hline 18 & 41ML269 & $\begin{array}{l}\text { glass, whiteware, stoneware, bricks, wire nails, cut nail, } \\
\text { well, concrete septic tank, concrete piers }\end{array}$ & no further work \\
\hline 20 & 41MA26 & debitage, tested pebble & $\begin{array}{l}\text { no further work in area } \\
\text { examined }\end{array}$ \\
\hline $25 / 29$ & 41CJ93 & debitage, burned rocks & no further work \\
\hline $25 / 29$ & 41CJ94 & debitage, burned rocks & no further work \\
\hline 26 & $41 \mathrm{BU} 72$ & debitage & no further work \\
\hline 30 & - & marked historic grave & $\begin{array}{l}\text { avoidance or grave } \\
\text { relocation }\end{array}$ \\
\hline 32 & 41WM908 & none & no further work \\
\hline 37 & 41DW275 & cores, tested cobbles, debitage, biface, burned rocks & no further work \\
\hline $39 / 56$ & $41 \mathrm{GZ210}$ & debitage, cores, biface & no further work \\
\hline 41 & $41 \mathrm{HI} 292$ & debitage, core, possible hammerstone, burned rocks & no further work \\
\hline 47 & 41BU51 & debitage, core, Godley dart point, burned rocks & test excavations \\
\hline 47 & 41BU54 & Cuney/Alba arrow point & no further work \\
\hline 47 & $41 \mathrm{BU} 75$ & debitage & test excavations \\
\hline 54 & 41TV2022 & $\begin{array}{l}\text { glass, whiteware, button, metal, bricks, animal bone, } \\
\text { well, cistern, corral, chicken coop, shed, } \\
\text { workshop/dwelling, outhouse, water tank, limestone } \\
\text { foundation, debris piles, modern trash }\end{array}$ & no further work \\
\hline 54 & 41TV2023 & $\begin{array}{l}\text { glass, ceramics, bricks, metal, ceramic tiles, collapsed } \\
\text { building, two wells, cedar post piers, brick-lined } \\
\text { walkway, debris piles, appliances, modern trash }\end{array}$ & no further work \\
\hline 55 & 41SV152 & $\begin{array}{l}\text { debitage, biface, charcoal, mussel shell, burned rocks, } \\
\text { burned rock features }\end{array}$ & test excavations \\
\hline 60 & 41HW47 & none & no further work \\
\hline 67 & 41FS92 & debitage, possible burned rocks & no further work \\
\hline 74 & 41FT529 & none & no further work \\
\hline 75 & 41LT70 & none & no further work \\
\hline 79 & 41BL259 & none & no further work \\
\hline 80 & 41KT32 & debitage, mussel shell & no further work \\
\hline 80 & $41 \mathrm{KT} 165$ & none & no further work \\
\hline 81 & 41ML77 & none & no further work \\
\hline 81 & 41ML24 & none & no further work \\
\hline 81 & 41ML28 & none & no further work \\
\hline 81 & 41ML80 & none & no further work \\
\hline 84 & 41GM3 & debitage & no further work \\
\hline $89 / 99$ & - & isolated historic-age well & no further work \\
\hline $89 / 99$ & - & possible historic-age cemetery & no further work \\
\hline $90 / 99$ & 41NL128 & debitage, tested cobbles, bifaces, uniface, burned rocks & no further work \\
\hline 91 & 41WM235 & none & no further work \\
\hline 91 & 41WM774 & none & no further work \\
\hline 91 & 41TV1134 & none & impact evaluation \\
\hline
\end{tabular}




\begin{tabular}{l|c|l|l}
\hline WA & Site & \multicolumn{1}{|c|}{ Materials Observed } & \multicolumn{1}{|c}{ Recommendation } \\
\hline 91 & 41 TV1135 & none & no further work \\
\hline 92 & $41 \mathrm{LE} 325$ & debitage, cores & no further work \\
\hline 93 & $41 \mathrm{HM} 46$ & burned rocks, charcoal, mussel shells & test excavations \\
\hline 95 & $41 \mathrm{FY} 420$ & debitage, burned rocks & no further work \\
\hline 97 & $41 \mathrm{BL} 1214$ & $\begin{array}{l}\text { debitage, mussel shells, charcoal, burned rocks, burned } \\
\text { rock features }\end{array}$ & test excavations \\
\hline 99 & $41 \mathrm{SN79}$ & debitage, bifaces, burned rocks & no further work \\
\hline
\end{tabular}

cultural materials were recovered from either trench.

The presence of datable charcoal and preserved faunal remains in an undisturbed buried context suggests that $41 \mathrm{WS} 56$ could contain important information and hence be eligible for listing in the National Register of Historic Places and designation as a State Archeological Landmark. Archeological testing would be required to determine this.

\section{Work Authorization 13: 41BL1155}

Historic-age site 41BL1155 was recorded during survey for straightening of a curve on Oakalla Road in Bell County. A historic-age structure was encountered in the southern portion of the proposed right of way. This singlestory house has a cut limestone chimney on the west side of the structure. The house is ca. $45 \mathrm{~m}$ north of the southern extent of the right of way and has dimensions of $12 x 7 \mathrm{~m}$. Soils around the property are extensively eroded because of driveways to adjacent properties and clearing near Oakalla Road. A cattle feeder is situated in the fenced front yard of the house, which also is littered with modern garbage and copious cow manure. No historic-age cultural materials were observed around the house, but because of its age, it was recorded as 41BL1155. The site was not shovel tested because of extensive erosion. The archeological component apparently has been destroyed by erosion and development nearby and thus lacks integrity. It is not eligible for listing in the National Register of Historic Places or designation as a State Archeological Landmark.

A files search turned up a letter to John Murphy (of the Texas Historical Commission's History Programs division) from Daniel Harris (architectural historian with the Historical Studies Branch of the Texas Depart- ment of Transportation's Environmental Affairs Division) dated December 10, 1999, addressing this historic-age structure. At that time, the structure was described as a vacant, single-story, side-gabled house with a full covered porch and a shed rear addition. In his letter, Mr. Harris states "The structure is currently vacant and shows severe signs of deterioration. Windows and one entryway are boarded up. No historicage farm related buildings are evidenced on the property. Due to loss of contextual and structural integrity this structure is not eligible for NRHP listing."

\section{Work Authorization 17: 41FA69}

Site 41FA69 was recorded as a result of survey for widening of shoulders on State Highway 14 in Falls County. It is the late-nineteenth- to early-twentieth-century Williams Cemetery, a fenced plot about $27 \times 18 \mathrm{~m}$ in size that contains 10 marked graves. The grave of William F. Williams is centered in the plot, and that of his wife, Amanda, is adjacent. The other graves appear to be children and extended family members. A historical marker at the cemetery reads: "Kentuckian W. F. Williams met Sam Houston in Tennessee and later joined his army to fight for Texas independence at the Battle of San Jacinto, April 21, 1836. Williams came to Falls County in 1857. A farmer and rancher, he was also a partner in Moseley and Williams General Store in nearby Kosse. He was a member of the Eutaw Lodge No. 233, A. F. \& A. M. He married Amanda Walling and had ten children." There are large oak trees in and around the cemetery. The cemetery is just east of the highway right of way, and survey consisting of Gradall trenching was done immediately west of the cemetery fence. No grave shafts or cultural materials were encountered in the trenches; thus, it appears that the cemetery does not extend into the existing right of way. 


\section{Work Authorization 18: 41ML269}

Historic-age site 41ML269 was recorded during survey for rerouting of a segment of FM 2837 and construction of a bridge at the South Bosque River in McLennan County. The site consists of a probable historic-age farmstead bounded by weathered cedar fence posts to the north and concrete fence posts to the west. The area within the fenced perimeter is ca. $85 \mathrm{~m}$ north-south by $75 \mathrm{~m}$ east-west. Scattered artifacts including manganese-solarized glass, whiteware, and brick fragments were observed in a plowed field as far as $75 \mathrm{~m}$ from the fence line. Although there are no standing structures, three features were recorded, including a limestone well $1 \mathrm{~m}$ in diameter and $2.7 \mathrm{~m}$ deep; a concrete septic tank $2 \mathrm{~m}$ long, $1 \mathrm{~m}$ wide, and $1 \mathrm{~m}$ deep; and eight concrete piers for an unknown structure set in a 7-m square pattern. Two shovel tests were excavated at the site. Shovel Test 1 was ca. $4 \mathrm{~m}$ southwest of the well and yielded 28 wire nails at $0-20 \mathrm{~cm}$. Two wire nails were recovered at $20-40 \mathrm{~cm}$, and 1 was recovered at 40-60 cm. Shovel Test 2 was within the fenced area of the site ca. $30 \mathrm{~m}$ west of the well in a clearing. The shovel test yielded 1 wire nail, 1 cut nail, 2 whiteware fragments, 1 brown glazed ceramic fragment, 2 pieces of clear glass, and 1 wire staple at $0-20 \mathrm{~cm}$. Given the predominantly twentieth-century age of the site and its overall poor condition, it appears to lack the capacity to yield important information and thus is ineligible for listing in the National Register of Historic Places or designation as a State Archeological Landmark.

\section{Work Authorization 20: 41MA26}

Part of previously recorded site 41MA26 was investigated during survey connected with widening of State Highway 21 in Madison County (the site likely extends northeastward onto lands to which access had not been obtained, and this area was not investigated). Four trenches were placed on or adjacent to the reported area of 41MA26 and confirm that the part of the site present in the section of new right of way surveyed consists of a shallow lithic scatter. Moore (2001:8) reported this scatter as representing a lithic-reduction and toolmanufacturing station. Only two lithic flakes were found in Trench 6 at ca. $20-30 \mathrm{~cm}$ below surface, although cultural materials could extend to the base of the sandy soils that blanket the upland margin on which the site rests (30$60 \mathrm{~cm}$ ). Trench 3 indicates that the sands become deeper downslope to the west, probably because of colluvium coming off the upland. A possible tested pebble was recovered in Trench 3 at ca. $100 \mathrm{~cm}$ below the surface on this slope. No features, midden-enriched soils, or diagnostic artifacts were noted in any of the backhoe trenches. Trenches 4 and 5 placed on the Iron Creek floodplain west of 41MA26 did not produce any cultural materials. These trenches encountered clay loam to firm clay sediments at $70 \mathrm{~cm}$ below the surface.

This survey confirmed the presence and previously reported extent of 41MA26 within the new right of way associated with the widening of State Highway 21 east of Iron Creek. But the fact that no features, midden deposits, or diagnostic artifacts were found suggests that this part of the site has little potential to substantially contribute to understanding Texas prehistory. In addition, no cultural materials were observed in the backhoe trenches on the Iron Creek floodplain. These findings indicate that the part of the site under consideration here is not eligible for listing in the National Register of Historic Places or designation as a State Archeological Landmark. But Moore (2001:12) suggested, and we concur, that it is likely that 41MA26 extends northeastward onto land to which TxDOT does not have access at this time but that is within the proposed right of way. It is recommended that 41MA26 be assessed further when right of entry has been obtained for this tract.

\section{Work Authorizations 25 and 29: 41CJ93 and 41CJ94}

Sites 41CJ93 and 41CJ94 were recorded during investigations for replacement of the bridge on County Road 152 at Copperas Creek in Comanche County. In April 2002, personnel from Prewitt and Associates performed an impact evaluation of the proposed bridge replacement and identified both sites. Site 41CJ93 was found immediately north of the existing bridge. Scattered burned sandstone and lithic debitage were observed across the graded road surface extending ca. $50 \mathrm{~m}$ north of the bridge and ca. 
$50 \mathrm{~m}$ east and west of the bridge. Site 41CJ94 was found immediately south of the bridge and also was defined by a scatter of burned sandstone and lithic debitage. A gully ca. $20 \mathrm{~m}$ east of the road revealed a stratigraphic profile of Holocene sandy loam alluvium and a paleosol at ca. $50 \mathrm{~cm}$ below the surface. A few pieces of burned sandstone were observed at the upper contact of the paleosol.

In May 2002, an archeological survey was conducted to document these sites. The survey of 41CJ93 revealed scattered pieces of burned sandstone and lithic debitage across the road right of way. No lithic tools or diagnostic artifacts were observed. Trench 1 was excavated ca. $25 \mathrm{~m}$ north of the bridge in a grassy triangular median at the intersection of County Roads 152 and 156. The trench was ca. $8 \mathrm{~m}$ long, $1.7 \mathrm{~m}$ deep, and $1.1 \mathrm{~m}$ wide and exposed scattered burned sandstone cobbles and a few chert flakes in the upper $50 \mathrm{~cm}$ of brown loamy sand. Materials appeared to be concentrated at the contact with an underlying paleosol in the northern portion of the trench. The southern portion of the trench revealed considerable disturbance in the upper $50 \mathrm{~cm}$ likely associated with construction of the existing bridge and road. A few burned rocks and a single piece of lithic debitage were observed below the paleosol in the east wall at $70-80 \mathrm{~cm}$. Shovel Test 1 was excavated in the west wall of Trench 1 to a depth of $100 \mathrm{~cm}$. At ca. $50 \mathrm{~cm}$, two pieces of burned sandstone were recovered, but no lithic tools or debitage were encountered. Trench 2 , excavated ca. $30 \mathrm{~m}$ east of Trench 1, was $7 \mathrm{~m}$ long, $1.6 \mathrm{~m}$ deep, and $1.1 \mathrm{~m}$ wide. This trench exhibited a similar profile as Trench 1, although the paleosol was slightly deeper at $60 \mathrm{~cm}$; no cultural materials were observed at the contact. A highly oxidized can was observed in the east wall at $45 \mathrm{~cm}$ suggesting that the upper sediments in this area are disturbed. Trench 3 was ca. $25 \mathrm{~m}$ west of Trench 1 and was ca. $7 \mathrm{~m}$ long, $1.6 \mathrm{~m}$ deep, and $1.1 \mathrm{~m}$ wide. A few scattered burned rocks were noted at ca. $20 \mathrm{~cm}$, but no lithic tools or debitage were observed in the trench walls or in the backdirt. The paleosol noted in Trenches 1 and 2 is not as pronounced in this trench.

The survey of 41CJ94 revealed scattered pieces of burned sandstone and lithic debitage across the County Road 152 right of way. No lithic tools or diagnostic artifacts were observed. Trench 4 was excavated ca. $10 \mathrm{~m}$ south of the bridge on the eastern shoulder of the road. The trench was ca. $7 \mathrm{~m}$ long, $1.7 \mathrm{~m}$ deep, and $1.1 \mathrm{~m}$ wide and exposed mottled sandy and clay loam sediments in the upper $65 \mathrm{~cm}$. This disturbed sediment is likely associated with construction of the existing bridge and roadway. No cultural materials were observed in the backhoe trench walls, although a few burned rocks were noted in the backdirt. Trench 5, ca. $60 \mathrm{~m}$ south of Trench 4, was $7 \mathrm{~m}$ long, $1.5 \mathrm{~m}$ deep, and $1.1 \mathrm{~m}$ wide. The upper $50 \mathrm{~cm}$ of sandy clay loam sediment appear to have experienced disturbance likely associated with road construction and maintenance. A single piece of burned sandstone was observed in the west wall at ca. $50 \mathrm{~cm}$, but no other cultural materials were noted in the walls or in the backdirt. Shovel Test 2 was excavated in the west wall of Trench 5 to a depth of $100 \mathrm{~cm}$. No cultural materials were recovered from the test.

Considering the existing impacts to the upper sediments at 41CJ93 and 41CJ94 and the fact that the proposed project requires blading the new bridge approaches to a depth of only $15-30 \mathrm{~cm}$ before a cap of $15 \mathrm{~cm}$ of crushed aggregate is applied, it appears the proposed construction activities will not disturb any cultural components that would be considered eligible for listing in the National Register of Historic Places or designation as State Archeological Landmarks.

\section{Work Authorization 26: 41BU72}

One prehistoric site, 41BU72, was recorded in the new right of way and drainage easement needed for replacement of the bridge on FM 1362 at Cedar Creek in Burleson County. The cultural materials observed consist of two chert flakes, only one of which was found in situ, located on the north bank of Cedar Creek. One flake was found on the exposed surface of the bank within $2 \mathrm{~m}$ of the creek bottom and clearly had eroded from the upper part of the bank. The second flake came from the upper $50 \mathrm{~cm}$ of the creek bank and was found in a brownish yellow sandy loam with distinct mottles of gray clay throughout. The gray clay mottles could be clay clasts suggesting that the soil zone may represent point bar deposits. This mottled soil zone follows the edge of the creek bank but does not appear in any of the four trenches dug farther north away from the creek. As such, it appears 
that the soil zone containing the flake is extremely localized. Given the obvious problem of bank erosion along this part of Cedar Creek, it is likely that this soil zone and the site have been extensively eroded and little of each now remains. This interpretation is supported by the fact that no cultural materials were found in any of the backhoe trenches. Based on the position of the trenches and the lack of any other materials along the northern creek bank, 41BU72 appears to extend only $5 \mathrm{~m}$ north-south by $10 \mathrm{~m}$ east-west.

Given that $41 \mathrm{BU} 72$ is extremely limited in extent and apparently contains few artifacts, its potential to contribute important information for understanding Texas prehistory is considered low. Thus, the site is not eligible for listing in the National Register of Historic Places or designation as a State Archeological Landmark.

\section{Work Authorization 30: Marked Historic Grave}

A marked historic-age or twentieth-century grave was identified but not assigned a trinomial during an impact evaluation for widening of RM 2341 in Burnet County. The grave is within the limits of the proposed right of way. The grave is on the north side of RM 2341 and ca. $2 \mathrm{~m}$ beyond the existing right of way boundary. The grave is that of Oscar K. Chestnut (1869-1936), and the marker reads "In loving memory of a real Texas cowboy." The grave appears to be well maintained and is fenced in. No other marked graves or areas that appear to contain unmarked graves were observed in the vicinity. Though the grave is probably not eligible for listing in the National Register of Historic Places or designation as a State Archeological Landmark, it should be investigated further if it will be disturbed.

\section{Work Authorization 32: 41WM908}

Previously recorded prehistoric site 41WM908 is in the area that will be affected by widening of RM 2338 in Williamson County. The site was recorded in 1997 by personnel from Paul Price Associates, Inc., as part of a survey for the Williamson County Regional Raw Water Pipeline. Chert cores, flakes, and one dart point pre- form were noted. The site subsequently was tested under Texas Antiquities Permit No. 2026 and found to be ineligible for listing in the $\mathrm{Na}$ tional Register of Historic Places or designation as a State Archeological Landmark (Schroeder et al. 2001). The Texas Historical Commission concurred with this recommendation.

The site was subjected to an impact evaluation to determine if intact portions are present in the project area, and if present, whether further archeological work would be necessary. The area examined included both sides of RM 2338 from Cedar Breaks Road to Shell Road (600 m northwest of Cedar Breaks Road). Surface inspection indicates that no part of the site remains intact within the existing right of way on either side of RM 2338. The existing right of way is characterized by limestone cobbles and gravels on the surface that appear to have been graded repeatedly as part of regular ditch and fill section maintenance. In addition, a water line has been installed just beyond the existing right of way boundary and within the proposed right of way on the north side of RM 2338. Disturbance south of RM 2338 in the proposed right of way and within the site boundaries includes an area of 1-2 acres that has been cleared and then covered with soil and possibly used as a construction easement. East of this cleared area, a new supermarket has been constructed. Parking facilities and drainage structures have disturbed areas in the existing and proposed rights of way and probably the eastern edge of $41 \mathrm{WM} 908$. Areas in the proposed right of way that are not disturbed but within the site boundaries are characterized by limestone bedrock at the surface. In sum, no cultural materials were observed within the existing right of way, and most of the land within the existing and proposed rights of way has been disturbed. Given the disturbances and the results of the previous work, there is no doubt that 41WM908 lacks the capacity to contribute important information and is ineligible for designation as a State Archeological Landmark or listing in the National Register of Historic Places.

\section{Work Authorization 37: $41 D W 275$}

Site 41DW275 in DeWitt County was recorded during survey of an approximately 20- 
acre gravel borrow pit to be used for various TxDOT projects. It is a low-density lithicprocurement and tool-maintenance and -manufacture site. The site covers all of the proposed borrow pit and surely extends beyond it. Lithic artifacts are visible on the surface mixed with natural gravels. Nineteen shovel tests were excavated across the area, and 17 contained artifacts. Most of the artifacts are in the upper $20-30 \mathrm{~cm}$ and are mixed with varying densities and sizes of gravels. Artifacts are densest in the north half of the site, closer to the Guadalupe River, where Shovel Tests 1-3 yielded 54, 47, and 37 artifacts. Most of the remaining shovel test yields averaged 2 to 6 artifacts. Observed artifacts include cores, tested cobbles, decortication flakes, interior flakes, chunks, potlids, heat-fractured chert chunks, a biface fragment, and a few burned rocks. The most predominant artifact classes are decortication flakes and interior flakes, suggesting early-, middle-, and late-stage biface reduction. No broken or unfinished tools or diagnostic artifacts were observed. In addition, no evidence of features was noted.

The 19 shovel tests ranged from 14 to $60 \mathrm{~cm}$ in depth and averaged around $30 \mathrm{~cm}$ because the gravel deposit is shallow. The deeper shovel tests were located in the southern half of the site. Artifact counts, however, decreased substantially in the southern half of the project area. Shovel test profiles were fairly consistent, with the upper $20-40 \mathrm{~cm}$ consisting of yellowish brown (10YR 5/4) loamy sand mixed with pebble-sized gravels and a smaller percentage of larger cobbles. Between 30 and $60 \mathrm{~cm}$, the matrix changes from yellowish brown sand to red (2.5YR 4/6) sandy clay containing dense gravels that are impenetrable with a shovel.

Six open test cores, located across the project area, were also inspected. These test cores are ca. $0.75 \mathrm{~m}$ wide and between 1 and $4 \mathrm{~m}$ deep; they probably were dug to determine the suitability of the project area for use as a borrow pit. Profiles of these cores revealed that the bottom of the densest lens of the gravel deposit, contained within both the yellowish brown sand and the underlying red sandy clay, is as deep as $95 \mathrm{~cm}$, although it averages ca. $65 \mathrm{~cm}$. Below the dense gravel lens is a very compact red clay that contains significantly fewer gravels than the upper deposit. Artifacts, including cores, tested cobbles, and a variety of flakes, were observed in low frequencies in the backdirt piles present around the rims of the test cores.

Based on the site's position atop a gravelcapped upland ridge, 41DW275 lacks contextual integrity and is limited in terms of its information potential. Thus, it is considered ineligible for listing in the National Register of Historic Places or designation as a State Archeological Landmark.

\section{Work Authorizations 39 and 56: 41GZ210}

An impact evaluation was performed for replacement of the County Road 240 bridge over Sandy Fork Creek in Gonzalez County in June 2002 , and $41 \mathrm{GZ} 210$ was recorded partially within the project area. The site was interpreted as a lithic procurement locale situated on the terrace edge south of and overlooking the creek. A biface fragment, two cores, and a large decortication flake were observed on the surface, which is characterized by a dense gravel deposit. During subsequent survey of the project area, the backhoe operator, a local resident, mentioned that the property adjacent to the site was once used for drilling for oil and that gravel was hauled in for the well pads and for the road into the wells. The gravel deposit, though containing authentic artifacts, apparently has been transported to the recorded site location; thus, $41 \mathrm{GZ} 210$ is in a redeposited context. More than likely, the gravels were acquired from a deposit containing lithic procurement debris. The lack of a site at this location was confirmed by the absence of artifacts in four trenches dug there. Site 41GZ210 is not eligible for listing in the National Register of Historic Places or designation as a State Archeological Landmark.

\section{Work Authorization 41: 41HI292}

Site $41 \mathrm{HI} 292$ was recorded during survey of new right of way needed for highway widening and replacement of the State Highway 31 bridge over an unnamed tributary of the Navasota River in Hill County. The site was identified in three of the eight trenches excavated in the area. It was exposed first in Trench 4, which was ca. $30 \mathrm{~m}$ south of the tributary channel on the $\mathrm{T}_{1}$ terrace. The profile of the trench showed a 60-cm-thick, well-developed A horizon on top of a grayish brown (10YR 5/2) 
sandy clay mottled with strong brown (7.5YR 5/ 8) sandy clay. Initially the trench was excavated about $1.3 \mathrm{~m}$ deep. As the backhoe moved southward to lengthen the trench, large river cobbles began to appear. Some of these looked heat fractured. A spall from a heat-fractured rock was then recovered, as well as more angular, fractured cobbles. Some large cobbles that did not appear to be heat fractured were also observed. The fire-cracked rocks seemed to be concentrated between 30 and $50 \mathrm{~cm}$ below the surface, and no cultural materials or large gravels were observed at all in the lower gray sandy clay. There was some doubt as to whether the heatfractured rocks were cultural because no other cultural materials (i.e., lithic debris) were observed. But as the trench progressed southward, stripping off only the upper $50 \mathrm{~cm}$, a chert core was observed. The trench was terminated at ca. $12 \mathrm{~m}$ in length when the fractured rocks seemed to dissipate. One interior flake and one possible hammerstone were recovered from the trench while examining the profile. In all, ca. 12 firecracked rocks or fragments were recorded in the trench.

Two additional trenches were excavated nearby. Trench 6 was placed ca. $12 \mathrm{~m}$ east and ca. $4 \mathrm{~m}$ south of the northern end of Trench 4 . The backhoe removed the upper $60 \mathrm{~cm}$ with shallow scrapes. Only two fire-cracked rocks were observed in the 10-m-long trench. Later, Trench 7 was placed between Trenches 4 and 6 , ca. $6 \mathrm{~m}$ east of Trench 4 and $4 \mathrm{~m}$ west of Trench 6 , and about $4 \mathrm{~m}$ south of the northern end of Trench 6. Trench 7 was excavated down to $60 \mathrm{~cm}$ and yielded only two fire-cracked rocks and no lithic debitage. The cultural materials were isolated between 30 and $50 \mathrm{~cm}$ below the surface, and unburned or fractured cobbles were also present. The archeological materials observed in Trenches 4, 6, and 7 were recorded as 41HI292. The site is a small, sparse fire-cracked rock and lithic (one core, one flake) scatter situated between 30 and $50 \mathrm{~cm}$ below the ground surface. The area likely has been plowed and cleared, and the site probably has been distrubed by these activities. The limits of 41HI292 are based on the trench excavations and estimated at $28 \times 28 \mathrm{~m}$.

Given its limited assemblage, poor context, and apparent lack of datable or diagnostic features or artifacts, 41HI292 lacks the capacity to yield important information. Hence, it is con- sidered ineligible for listing in the National Register of Historic Places or designation as a State Archeological Landmark.

\section{Work Authorization 47: 41BU51, 41BU54, and 41BU75}

Two previously recorded sites (41BU51 and 41BU54) and one newly recorded site (41BU75) were investigated during survey for widening of FM 60 in Burleson County. Site 41BU51 is situated in sandy sediments on the wall of the Brazos River valley south of Old River and east of FM 60. The site was recorded in 1971 when William Moore found one projectile point; the site appears to have experienced little change since then. A two-track road bisects the terrace edge that the site occupies. The terrace appears to have been quarried for sand, resulting in a bowl-shaped borrow area. The borrow area is ca. $2 \mathrm{~m}$ deep and ca. $40 \mathrm{~m}$ wide; thus, a narrow ridge borders the north side of the road, and the remainder of the terrace continues south of the depression. The north slope of the terrace is eroded, and artifacts were noted at about $20 \mathrm{~cm}$ below the surface. The artifacts appeared to occur just above the contact between an upper tan sand (ca. 20-25 cm thick) and an underlying hard red clay (i.e., Pleistocene terrace). Given the shallow nature of the materials in this area of the site, no excavations were performed. Trench 2 was excavated north of the borrow pit, toward Old River, about 10-12 m east of FM 60. The trench was excavated to ca. $1.5 \mathrm{~m}$ and encountered hard red Pleistocene clay below tan sand. While inspecting the trench walls, several flakes ( $n=20), 1$ pebble core, 2 fire-cracked rock fragments, and 1 Godley-like dart point were recovered. All of the artifacts came from between 1.4 and $1.5 \mathrm{~m}$ below the surface, within the tan sand and right on top of the Pleistocene clay. Trench 3 was ca. $75 \mathrm{~m}$ south of Trench 2 on the terrace surface south of the borrow pit. The trench was excavated to a depth of $60 \mathrm{~cm}$, through the tan sand, before encountering the red Pleistocene clay. Just above the contact with the clay, 2 flakes and 1 fire-cracked rock were observed; hence, this area was included as part of 41BU51. Based on the artifacts observed in Trenches 2 and 3, the cultural deposit appeared to be fairly discrete and limited to the $10 \mathrm{~cm}$ just above the red clay. Because of the discreteness of the deposit, 41BU51 was considered to 
have the potential to contain important information and test excavations to assess its eligibility for listing in the National Register of Historic Places and designation as a State Archeological Landmark were recommended.

Site 41BU54 also was revisited during the survey. The original site boundaries, as recorded in 1991, were limited to the west side of FM 60 in a large area quarried for sand on the ridge just south of the Davidson Creek valley. At that time, ceramics and a grinding stone were observed, and local residents had reported collecting arrow points from the disturbed area. The quarried locale is at least $1 \mathrm{~m}$ deep and $10-30 \mathrm{~m}$ wide, and it is immediately adjacent to FM 60 . During this project, seven shovel tests were excavated on the east side of the road across from the original plotted location of 41BU54 in the area of proposed new right of way. The sediments along the terrace are extremely thin, with ca. $20 \mathrm{~cm}$ of tan sand on top of red Pleistocene clay. One arrow point fragment, resembling a Cuney or Alba point, was found in Shovel Test 7 at 0 $10 \mathrm{~cm}$. No other artifacts were observed in Shovel Test 7, in any other shovel test, or on the surface. The 41BU54 site boundaries were extended to encompass the point fragment and the shovel tested area, but it does not appear that significant cultural deposits extend east across FM 60. Given the thin nature of the deposits within the eastern portion of the site and the disturbed nature of the western portion of the site as a result of quarrying, 41BU54 is considered ineligible for listing in the National Register of Historic Places or designation as a State Archeological Landmark.

Site $41 B U 75$ is a buried campsite yielding lithic debris and one possible piece of bison bone. The site is situated on an eroded $\mathrm{T}_{2}$ Pleistocene terrace of the Brazos River overlooking Old River to the north, south of 41BU51. The terrace surface is mantled by ca. $1 \mathrm{~m}$ of late Holocene sand. The terrace surface stands 4$5 \mathrm{~m}$ above the Old River floodplain and gently slopes to the east, then dropping off steeply toward the floodplain to the north. Artifacts were discovered in all six shovel tests at 41BU75, with Shovel Test 4 yielding 3 flakes, Shovel Tests 1 and 3 each yielding 4 flakes, Shovel Test 6 yielding 13 flakes, Shovel Test 2 yielding 27 flakes, and Shovel Test 5 yielding 30 flakes. Seventyseven percent of the artifacts came from the upper $60 \mathrm{~cm}$ of the tests, although some were found to the base of the excavations at $100 \mathrm{~cm}$. No diagnostic artifacts were recovered, but one possible piece of bison bone was recovered from Shovel Test $2(20-40 \mathrm{~cm})$. The bone is believed to be an astragalus. Given the thickness of the sandy deposit, it is possible that intact deposits could be present beneath the plowzone. If so, the site may contain important information. Test excavations would be needed for a full assessment of this site's eligibility for listing in the National Register of Historic Places and designation as a State Archeological Landmark.

\section{Work Authorization 54: 41TV2022 and 41TV2023}

Two historic-age sites were recorded in areas that will be affected by widening and realigning FM 973 in Travis County. The more-southern site, 41TV2022, is ca. $100 \mathrm{~m}$ west of FM 973 and $1.4 \mathrm{~km}$ north of the intersection of FM 973 and U.S. Highway 290. Site 41TV2022 appears to be the remains of a farming and ranching complex covering ca. $10,800 \mathrm{~m}^{2}$. The site is in a patch of large oak trees and tall grasses surrounded by plowed fields. The site contains one brick-lined well and one cistern (at opposite ends of the site); a corral; a chicken coop; a large open storage shed that is still in use; a small workshop or dwelling with a concrete floor, intact roof, and board-and-batten siding; a water tank; the partial limestone slab foundation of what may have been a house; several piles of debris, including bricks and boards of varying sizes (mostly $2 \times 4$ and $2 \times 6$ inches); and the remnants of what may have been another building.

The partial limestone foundation in the west half of the site is clearly associated with the brick-lined well, the small workshop or dwelling, the water tank, and what may have been a garden or yard area near the western boundary of the site. The foundation elements are ca. $50 \mathrm{~cm}$ wide and vary from 50 to $100 \mathrm{~cm}$ long and are in a $7 \times 7-\mathrm{m}$, L-shaped arrangement. Construction materials in the small building with the concrete floor appear to be original and include cut nails, noncorrugated sheet metal, and 1x6-inch and 1x2-inch boards for the boardand-batten construction. The building shows a hipped roof and thus likely dates to the $1920 \mathrm{~s}$, although it could date as early as the late 1890s. Whole bricks observed on the surface scattered around the site are plain red, plain yellow, or 
red stamped with the FERRIS brand name. FERRIS bricks were made by the Ferris Press Brick Company out of Ellis County, Texas. These particular bricks are believed to have been manufactured between 1901 and 1923 (Steinbomer 1982). The storage facility, composed mostly of corrugated sheet metal, is still in use and appears to have been modified, or at least reconstructed to some degree, with modern structural and roofing materials (modern nails and lumber). A large linear trash pile associated with the facility includes mostly modern trash (i.e., aluminum cans, carpet, plastic and glass bottles, scrap metal, wood), but part of a brick chimney was observed in the pile. A wooden outhouse abuts the northwest corner of the storage facility, but it is unclear if this is its original location. What appears to be a corral or barn is situated in the northeast area of the site. Some corrugated metal sheeting is still attached to the wood fencing along the side of the corral, and ca. 8-ft-tall cedar poles still stand in the center of the corral giving the impression that the entire corral was covered at one time. A wagon axle with partial wheels and spokes was observed within the fenced area of the corral. A large pile of $1 \times 6$-inch and $1 \times 4$-inch boards was observed in the eastern portion of the site near what is believed to be a brick-lined cistern. No foundation remains associated with the boards were observed near the cistern, however.

Seven shovel tests were excavated across the site into dark to light gray clay. The tests were 40-50 cm deep and yielded very few artifacts. Artifacts observed in the tests consisted of one piece of milk glass, one pork chop bone, two brick fragments, and one large metal screw that did not appear to be machine made. All of the artifacts came from the upper $10 \mathrm{~cm}$. Many artifacts were observed scattered across the surface of the plowed field surrounding the site, including clear, brown, green, and purple glass; whiteware (some with blue transfer print); earthenware; one shell button; and red and yellow bricks and brick fragments.

The second site, 41 TV2023, is ca. $5.5 \mathrm{~km}$ north of 41TV2022 and is immediately west of and adjacent to FM 973. It appears to be the remains of at least one house site, possibly two, that covers ca. $11,700 \mathrm{~m}^{2}$. The site is in a wooded but not overgrown area. The site contains one small collapsed building, two brick-lined wells at opposite ends of the site, a series of burned cedar posts that appear to be the remnants of a foundation, an associated brick-lined walkway, several large piles of scrap metal, scattered appliances (i.e., refrigerators, stoves), miscellaneous machine parts, and a broken-down Chevrolet Stylemaster.

The remains of the cedar post foundation are located ca. 8-9 m west of FM 973. Currently, 10 posts are present in a rectangular shape over a $6 \mathrm{x} 4-\mathrm{m}$ area. All posts appear to be burned on the top. The cedar posts are associated with a large burned brick and melted glass midden. To the south of the cedar posts is a $1 \times 9-m$ bricklined walkway. Some limestone slabs are present at the north end of the walkway near the posts. The walkway apparently led to the edge of a driveway off of FM 973. About $1 \mathrm{~m}$ east of the slabs, along the fence, is a small gate perhaps for a front yard entrance from FM 973. Also associated with the posts and the burned bricks and glass is a small refrigerator with metal casing, a stove, and a brick-lined well (or possible cistern) that has a pipe connected to it that angles toward the foundation posts.

A small collapsed building is present in the southwest corner of the site. The building is ca. $5 \times 5 \mathrm{~m}$ and is constructed of $1 \mathrm{x} 6$-inch boards and noncorrugated metal roofing. A modern stove is associated with the building. Approximately $12 \mathrm{~m}$ northeast of the building is a Chevrolet Stylemaster turned on its side. The car dates to the mid to late 1940 s and is in poor condition. Another small, metal-encased refrigerator is $3 \mathrm{~m}$ east of the car and near a small but dense midden. Shovel Test 3 was excavated in the midden and revealed that it is about $25 \mathrm{~cm}$ deep. Materials in the midden include a wide variety of glass, bathroom tiles, ceramics, brick fragments, metal fragments, and some roof tiles. Some of the material appears to date to the early to mid twentieth century, but the remainder is more modern. A larger pile of scrap metal is about $3 \mathrm{~m}$ north of the car and near a large metal water tank resting on the ground. Just east of the water tank and along an east-west fence line are several more piles of scrap metal and miscellaneous debris, including glass bottles, cans, bricks, and a variety of other items. These piles probably were pushed against the fence during installation of a water line through the middle of 41TV2023. North of the water line are a second well, two large concrete blocks, an underground ceramic pipe (perhaps for a septic 
system), and a fairly large artifact scatter. Artifacts observed on the surface include broken glass (brown, clear, and purple primarily), bottle tops, whiteware, and earthenware.

Six shovel tests were excavated across 41TV2023 into dark gray clay. The tests were 40-50 cm deep and yielded very few artifacts. Artifacts observed were one piece of clear glass, one small fragment of rusted metal, one small fragment of purple glass, and one sherd of earthenware. All of the artifacts came from the upper $10 \mathrm{~cm}$.

A review of the 1896 USGS topographic map of the area (Austin, Tex.) revealed that buildings were not present at the locations of either of these sites when the mapping was done in 1895-1896. Although USGS maps of this vintage cannot always be relied on to show all buildings because of the map scale (in this case 1:125,000) and the distances between buildings and roads, this probably is not a problem for this project area for the following reasons: (1) one of the locations was adjacent to the road in 1895-1896, and the other was not far off the same road; (2) the area likely was open farmland with good visibility in 1895-1896; and (3) this map shows several structures well removed from roads. Thus, there is no reason to think that buildings were actually present at these two locations but not visible to the surveyors, and it appears that the archeological remains at the two locations postdate 1895-1896. Materials observed at the sites, including the structural remains of buildings and associated artifacts and debris, suggest early-twentiethcentury occupations at both locations with later occupations following.

Based on historic-age map research and archeological survey, it appears that both sites date mostly, if not entirely, to the twentieth century. Only one site, 41TV2022, contains a standing building. This small building, perhaps a workshop or dwelling, has architectural features (i.e., hipped roof, board-and-batten construction, concrete floor) that suggest a 1920 s, or possibly slightly earlier, construction date. The modest building does not, however, articulate the kinds of architectural features or style that typically would indicate eligibility for listing in the National Register of Historic Places. Other buildings that may have been present at both locations have either been razed or are in such a dilapidated state that they completely lack in- tegrity. Given the lack of integrity and poor overall context observed at both sites, the lack of significant subsurface cultural remains, and the apparent occupation dates, it would seem that both sites have limited potential to yield important information. Hence, 41TV2022 and 41TV2023 are considered ineligible for listing in the National Register of Historic Places or designation as State Archeological Landmarks.

\section{Work Authorization 55: 41SV152}

Prehistoric site 41SV152 was recorded just west of and on a gradual slope overlooking a tributary to Georges Creek in Somervell County during survey for widening of U.S. Highway 67 and replacement of the bridge over the Brazos River. Ten shovel tests were excavated within the boundaries of the site. The deposits at the site are fairly shallow and are characterized by 25-65 cm of brown sandy loam on top of hard red clay. Two burned rock features were encountered in Shovel Tests 17 and 19, which were located ca. 35-40 m apart. Feature 1, discovered in Shovel Test 17, consisted of 6-7 pieces of burned limestone averaging about $6-7 \mathrm{~cm}$ in size and surrounded by discolored, burned sediment. A thin, finely worked biface fragment, 1 flake, and charcoal flecks seemed to be associated with the small rock cluster. One other flake was found above the feature at $20-25 \mathrm{~cm}$. The feature was recorded at a depth of $25-30 \mathrm{~cm}$ and was situated at the contact between the brown sand and the underlying red clay. Feature 2 was discovered in Shovel Test 19 and consisted of at least 12 burned rocks averaging $8-10 \mathrm{~cm}$ in size in a tight cluster. Again, some soil discoloration and charcoal flecking were observed around the rocks. Seven pieces of burned rock were noted in the upper $20 \mathrm{~cm}$ before the feature was encountered. Feature 2 was located about $17 \mathrm{~cm}$ below the surface within the brown sandy loam matrix, which extended to at least $25 \mathrm{~cm}$. No cultural materials other than burned rocks were found in Shovel Test 19. All 10 shovel tests at 41SV152 contained cultural materials, totaling 45 pieces of debitage (mostly small interior flakes of various siliceous materials), 1 biface fragment, ca. 14 burned rocks (other than those in Features 1 and 2), and a single mussel shell. Shovel Tests 11-15, 17, and 18 each contained 3-5 lithic artifacts, and Shovel Tests 16 and 20 produced 10 and 8 lithics; no debitage was found 
in Shovel Test 19. By far, most of the chipped stone artifacts $(n=40)$ were found in the upper $20 \mathrm{~cm}$; only 6 artifacts were found at $20-40 \mathrm{~cm}$ in the 9 shovel tests that went this deep. The sands exceeded $40 \mathrm{~cm}$ in thickness in four tests, with no artifacts coming from the $40-60-\mathrm{cm}$ level. No artifacts were noted on the surface of the site, although vegetation made visibility poor. Based on the results of shovel testing and the landform, 41SV152 appears to cover an area of ca. $60 \times 40 \mathrm{~m}$. In general, the site seems to be by and large intact even though it is shallowly buried. Some evidence of clearing was observed in the form of two small, $5 \times 10-\mathrm{m}$ push piles, and cow trails were observed across portions of the site. Their effects below the ground surface seem limited, however.

Though the site is in thin, probably colluvial, Holocene deposits in an upland setting, the presence of apparently intact features, datable charcoal, and other cultural materials suggests that the site could contain important information. Testing is recommended to ascertain this and to assess the site in terms of its eligibility for listing in the National Register of Historic Places and designation as a State Archeological Landmark.

\section{Work Authorization 60: 41HW47}

An area adjacent to previously recorded site 41HW47 was investigated during survey for rehabilitation and widening of FM 669 in Howard County. The site, recorded in 1993, is on a low rise ca. $0.5 \mathrm{~km}$ east of a large playa. At the time it was recorded, the entire site area was under cultivation and consisted of a scatter of burned caliche and lithic debitage. A revisit to the site by the initial recorders three days after their survey revealed that most of the site's contents were no longer visible because of plowing. They reported an 80 percent decrease in the frequency of artifacts observed on the surface. The site was considered ineligible for listing in the National Register of Historic Places (Staley and Evaskovich 1993).

The existing right of way of FM 669 adjacent to the plotted location of the site was visited and subjected to thorough pedestrian survey. Because of extensive disturbances, no shovel tests were dug. No artifacts were observed on the surface, which has been disturbed by grading and ditch maintenance and is rut- ted with tire tracks. Caliche rocks and asphalt chunks and gravels, but no artifacts, were observed across the surface. Whatever portion of the site that once extended into the existing right of way apparently has been destroyed. This portion of $41 \mathrm{HW} 47$ is deemed ineligible for listing in the National Register of Historic Places or designation as a State Archeological Landmark.

\section{Work Authorization 67: 41FS92}

Prehistoric site 41FS92 was recorded during completion of an impact evaluation for replacement of the bridge on County Road 208 at Bull Creek. It sits atop the $\mathrm{T}_{1}$ landform 5-6 m above the channel on the south side of the creek; this may be a very old alluvial terrace, or it may represent colluvial deposits from the Permian uplands to the south and north. This site consists of 10-15 mostly decorticate chert flakes and ca. 5 possible burned rocks (limestone and sandstone) on the $T_{1}$ surfaces above the road cut on both sides of CR 208. A few flakes were noted on the exposed faces of the 2-m-deep road cut, but none of these appeared to be in situ; instead, they appear to have been displaced from the $\mathrm{T}_{1}$ surfaces above by erosion. Despite excellent visibility provided by the road cut, no intact subsurface remains were observed. The artifact scatter covers an area of ca. $15 \mathrm{~m}$ north-south. The east-west dimension is unknown because only 1-2 $\mathrm{m}$ of the $\mathrm{T}_{1}$ landform remain on both sides of the road within the existing right of way. Based on the extent of the landform, however, the site could extend at least 20 m east and west of the road. Because of the lack of subsurface deposits and the sparseness of cultural materials, this site appears to have little capacity to contribute important information and is considered ineligible for designation as a State Archeological Landmark or listing in the National Register.

\section{Work Authorization 74: 41FT529}

Previously recorded site 41 FT529 was investigated during survey for rehabilitation of the west frontage road of Interstate Highway 45 in Freestone County. The site is in the median between the northbound and southbound lanes of Interstate Highway 45, south of Caney 
Creek. This site was recorded by avocational archeologist Bill Young based on many visits in the 1980 s. He reported finding lithic debitage, dart points, arrow points, scrapers, bifaces, cores, ceramics, and burned rocks in exposed areas on the flanks of the ridge, which had been disturbed by highway construction and erosion.

Most of the ridge was accessible for inspection during the survey. The only part that could not be inspected was the northwestern section, which is covered with a dense growth of thorny berry vines. Most of the area has been badly disturbed. The only relatively intact part of the landform is a narrow strip of ridge crest that parallels and immediately adjoins the west edge of the road cut for the northbound lanes of Interstate Highway 45. This crest area is only ca. $5 \mathrm{~m}$ wide along the north part of the ridge, widening to as much as $10 \mathrm{~m}$ to the south. The crest is covered in grass and weeds and offers virtually no ground surface visibility. The pavement for the northbound lanes is ca. $28 \mathrm{~m}$ east of this ridge crest and ca. $4 \mathrm{~m}$ lower (i.e., in a deep road cut). A ca. 1-m-deep ditch lies at the base of the road cut ca. $6 \mathrm{~m}$ west of the pavement. The moderately steep road cut slope is covered in grass, offering no visibility. The part of the landform west of the crest has been beveled, probably as a result of earthmoving during highway construction. Though covered in grass, weeds, and small trees, some areas are exposed and show red sandy clay bedrock with ironstone gravels, siliceous (Uvalde?) gravels, and large sandstone slabs. The red sandy clay is Eocene bedrock. This area slopes down for a distance of ca. $50 \mathrm{~m}$ to ca. $4 \mathrm{~m}$ below the crest of the ridge. Then, at ca. $20 \mathrm{~m}$ from the pavement for Interstate Highway 45 southbound, it slopes back up for ca. $1 \mathrm{~m}$ in a linear berm that parallels the southbound lanes. This berm appears to be redeposited sandy sediments, perhaps from beveling of the higher slope to the east. West of the berm toward the southbound lanes is a 1-2-m-deep ditch paralleling the freeway.

Five shovel tests were put at ca. 20-m intervals along the crest of the ridge, just west of the edge of the road cut for the northbound lanes. These tests started on the lower north slope of the ridge and extended southward well up onto the summit. They were dug in 20 -cm levels, and all sediment removed was screened through 1/4-inch mesh. All five tests encountered thin $(18-60 \mathrm{~cm})$ pale brown sand over yellowish red sandy clay. Chunks of red clay, along with occasional gravels, were found in the sands in most tests and suggest that the deposits are disturbed. A sixth test was placed on the beveled western slope; only $7 \mathrm{~cm}$ of sand on top of red sandy clay were encountered. No artifacts were found in any of the tests. Nor were artifacts noted in the surface exposures (ca. 10 percent) on the western slope. It appears that 41FT529 has been destroyed, although it is curious that no artifacts were found in the shovel tests. There is no doubt about this being the right location, and the sketch map with the site form shows clearly that the ridge crest and adjacent slopes were where the recorders had found artifacts. In any case, if any cultural materials remain, they must be very sparse based on the lack of materials in the tests. Site 41FT529 lacks important archeological remains and is ineligible for listing in the National Register or designation as a State Archeological Landmark.

\section{Work Authorization 75: 41LT70}

The vicinity of previously recorded site 41LT70 was investigated during an impact evaluation for rehabilitation of FM 1245 in Limestone County. The site is plotted as lying on both sides of Christmas Creek just north of FM 1245. The limited information available indicates only that the site was recorded by avocational archeologist Frank Bryan in the 1930s.

The existing right of way at this location has been disturbed extensively by fill sections, drainage ditches, buried utilities, and erosion. Fill sections at both ends of the existing bridge are $2-3 \mathrm{~m}$ thick and extend ca. $100 \mathrm{~m}$ eastward from the creek and ca. $200 \mathrm{~m}$ westward. The fill sections cover almost all of the existing right of way. Drainage ditches parallel both sides of the fill sections, and a buried cable is present along the southern edge of the existing right of way at the bases of the fill sections. Gullying and erosional beveling of the terrace margin are extensive just outside the existing right of way in the northeast and southeast quadrants of the project area. Shovel testing to look for remains of 41LT70 in the existing right of way was not feasible because of the extent of disturbance.

Surface visibility was very poor, though isolated areas in the northeast and northwest 
quadrants offered 100 percent surface visibility. Also, cutbank profiles along Christmas Creek afforded some subsurface exposures. These profiles indicate the presence of 3-4 $\mathrm{m}$ of Holocene alluvium. The profiles also provide evidence of very recent cut and fill episodes (gullying) at the northeast corner of the bridge. No evidence of 41LT70 was observed, and it appears that intact deposits relating to the site do not extend into the existing right of way.

\section{Work Authorization 79: 41BL259}

Part of previously recorded site 41BL259 was investigated during survey for construction of a hike-and-bike trail paralleling a portion of Nolan Creek within the city limits of Belton. The site was recorded by C. Jurgens and H. Whitsett in 1982 and is $580 \times 250 \mathrm{~m}$ in size. It occupies the floodplain on the south side of Nolan Creek and reportedly represents the original settlement of Belton. Various nineteenth-century glass, ceramic, and metal artifacts were observed, as well as the remains of a cut limestone well house and a few prehistoric artifacts. Jurgens and Whitsett noted that recent development, including the construction of Interstate Highway 35 and associated frontage roads that cross the site had disturbed or partially destroyed it. They also observed that the level of disturbance appeared to be greater west of Interstate Highway 35, whereas east of the highway, the site appeared to be relatively undisturbed. Developments that had disturbed the western half of the site included the construction of the Belton Rodeo grounds, a city park, a wastewater line, and Confederate Park Drive. In addition, a low concrete wall had been constructed on a portion of the floodplain surface occupied by the site, and fill had been added to level or terrace the surface.

No historic-age artifacts associated with the site were found during survey; the only cultural materials observed were modern glass, metal, and plastic in the recent flood deposits mantling the floodplain surface. Recent debris also was noted on the surface, as were two clusters of domestic vegetation (irises) near the north end of the trail south of its crossing of Nolan Creek. Irises often mark historic-age sites (both house sites and cemeteries), but no evidence (e.g., landscaping features or structural remains) was ob- served on the surface to indicate that this is the case with these irises. In fact, Trench 4 placed nearby shows that this part of the floodplain contains $60 \mathrm{~cm}$ of recent alluvium (dark gray clay loam with common thin beds of gravels and sands), indicating that intact, historic-age deposits are very unlikely. Further, Sanborn fire insurance maps for 1921, 1926, and 1949 do not show any structures, cemeteries, or other historic-age features in this area. Earlier Sanborn maps of Belton (1885, 1891, 1896, 1902, 1907 , and 1912) do not cover this area, suggesting that development in this part of town was limited before the second decade of the twentieth century. By 1921, the area contained scattered residences, a school for African-American children, and two African-American churches. All were west and south of the current project area; closest to the iris patches (about a block away on the northeast corner of Burnett Street and 5th Avenue) were the African Methodist Episcopal (AME) church and a residence. Little had changed by 1926, except that the AME church was gone. By 1949, a few more residences had been built, and the school had moved a block west to the northeast corner of Smith Street and 4th Avenue, but still no features were mapped in the vicinity of the iris patches. Based on the evidence from Trench 4 and the Sanborn maps, it is highly unlikely that the iris patches near the trail south of Nolan Creek mark significant historic-age features. The iris bulbs may have washed in during modern floods or been dumped there with other modern trash, or perhaps the patches represent the remnants of gardens planted near the creek by people who occupied houses west and south of the proposed trail.

Although the eastern end of the proposed trail will intersect 41BL259, anticipated disturbances from this project will be minimal. Furthermore, the site already has been disturbed by development, particularly the western half of the site where the trail will terminate, and no archeological materials were encountered on the surface or in the trenches. Domestic vegetation was noted on the surface in one area but appears not to mark significant historical remains. Given the lack of archeological materials, the project appears to have no potential to affect archeological sites that are eligible for listing in the National Register of Historic Places or designation as State Archeological Landmarks. 


\section{Work Authorization 80: 41KT32 and 41KT165}

Parts of previously recorded sites 41KT32 and $41 \mathrm{KT} 165$ were investigated during an impact evaluation for widening of State Highway 208 in Kent County. Site 41KT32 is an open prehistoric campsite situated on the south side of the Salt Fork of the Brazos River west of the highway. Testing took place at 41KT32 in 1983 and consisted of the excavation of a $1 \times 2-m$ unit in the existing right of way and three $1 \times 2-m$ units and one $1 \mathrm{x} 1-\mathrm{m}$ unit in a temporary easement area just west of the existing right of way (Denton 1983). The excavations and surface collection found scattered burned sandstone rocks (but no intact features) and 733 lithic artifacts, including 7 projectile point fragments, 4 biface fragments, 3 unifaces, 701 pieces of debitage, 5 cores, 4 hammerstones, 4 manos, 1 grinding stone, a possible sandstone pestle, and 3 smooth quartzite fragments. Most of the cultural materials were found at $10-30 \mathrm{~cm}$ below the surface. The testing indicated that the part of the site outside the highway right of way might contain important information but that the part within the right of way had been largely destroyed by previous road construction.

An area ca. $150 \mathrm{~m}$ long in the southwest corner of the bridge area between the edge of the road and the edge of the right of way was examined at 41KT32 during the impact evaluation. Most of this area has been disturbed by previous road and bridge construction. Much of the area has been lowered below grade and then built up with 3-4 m of fill. A small gully $(<60 \mathrm{~cm}$ deep) also is present in the southern portion of the area examined. Although cultural materials associated with 41KT32 were observed on the surface outside the right of way, artifacts within the right of way were limited to a small area measuring ca. $40 \times 2-3 \mathrm{~m}$ and paralleling the fence line. This area stands about $1 \mathrm{~m}$ above the surrounding area, which was lowered for road and bridge construction. Lithic debitage and a mussel shell were observed on the surface of this small area and eroding out of the face of the road cut. The area is riddled with rodent burrows. Based on the limited extent of the site in the right of way, the presence of extensive disturbance from previous road and bridge construction, and the findings of the 1983 testing, it appears that the part of 41KT32 that is within the right of way has no capacity to contribute important information and is ineligible for listing in the National of Historic Places or designation as a State Archeological Landmark.

Records at the Texas Archeological Research Laboratory indicate that $41 \mathrm{KT} 165$ is a cache of bifaces that was recovered west of State Highway 208 about $5.1 \mathrm{~km}$ northwest of the Salt Fork of the Brazos River. The circumstances of the discovery of this cache are unclear. At this locality, both sides of the right of way were examined for ca. $100 \mathrm{~m}$ in both directions (north and south) of the plotted site location during the impact evaluation. Surface visibility was good (50 percent or better), and several backdirt piles from rodent burrows were present and examined. No cultural materials were observed within the right of way or just outside of the right of way. It appears that the site was an isolated cache of artifacts that was removed when the site was recorded. Hence, it has no capacity to contribute important information and is ineligible for listing in the National Register of Historic Places or designation as State Archeological Landmarks.

\section{Work Authorization 81: 41ML77}

An area adjacent to previously recorded site 41 ML77 was investigated during an impact evaluation for upgrading the guard fences at the U.S. Highway 84 bridge over Williams Creek in McLennan County. The site reportedly adjoins the project area, just north of the highway and east of Williams Creek. The only thing known about it is its location. It was recorded in the 1930s by Frank Bryan.

The existing right of way at Williams Creek has been disturbed by fill sections, ditch excavation, and buried utilities, as well as construction of relief structures ca. $140 \mathrm{~m}$ east and $105 \mathrm{~m}$ west of the main channel. A fill section 2-3 m thick extends east of the creek to the relief structure, occupying all but ca. $5 \mathrm{~m}$ of the right of way on either side of the road. The fill section west of the creek to the relief structure is 1.5$2.0 \mathrm{~m}$ thick and covers all but a few meters of the right of way on either side of the road. Ditches take most of the right of way beyond the fill sections in three quadrants of the project area; these ditches are 0.5-1.5 m deep. Buried utilities consist of telephone lines at both the north and south edges of the right of way. 
Surface visibility was poor over most of the project area, although it was fair (50 percent) on the southwest and northwest banks of the creek. A cutbank just northeast of the bridge provided some subsurface visibility and revealed that at least $5 \mathrm{~m}$ of Holocene alluvium is present. No archeological materials were observed in this cutbank or on the surface. Site 41ML77 probably lies within alluvial deposits north of the right of way and east of the creek. This area is in pasture and appears to be undisturbed. Intact archeological remains associated with the site (or at least its upper meter or so) do not extend southward into the existing right of way, however, as this area has been disturbed by fill placement, the excavation of a broad ditch (ca. $1.0 \mathrm{~m}$ deep), and placement of a buried telephone line.

\section{Work Authorization 81: 41ML24, 41ML28, and 41ML80}

Areas near previously recorded sites 41ML24, 41ML28, and 41ML80 were investigated during an impact evaluation for lengthening culverts and adding safety end treatments on State Highway 6 in McLennan County. Site 41ML24 is near the eastern part of the project area south of the highway on the uplands east of the Tehuacana Creek floodplain. Recorded by Lathel Duffield, probably in the 1960s, it apparently is a sparse lithic scatter from which a metate and drill fragment were collected. Site 41ML28 is near the western part of the project area, south of the highway and north of the Brazos River. It apparently was a historic-age Native American village that was tested in the 1960 s and first recorded sometime before that. Site $41 \mathrm{ML} 80$ is not far east of 41ML28, also south of the highway and north of the Brazos River. Other than the fact that it is was recorded by Frank Bryan in the 1930s, nothing is known about it.

The south side of State Highway 6 near 41ML24 has been disturbed chiefly by road cutting, with some disturbance also from buried utilities. The highway at this location has been cut $2-5 \mathrm{~m}$ deep into the uplands, leaving only 2-6 $\mathrm{m}$ of relatively intact upland surface at the top of the cut along the south edge of the right of way. This upland surface has been disturbed by buried telephone and fiber optic cables and a water line, however. In addition, a gas pipeline crosses the highway at this location. Both of the driveways with culverts that will be improved during this project are at the bottom of the road cut, well below the upland surface. Surface visibility was generally poor ( $<10$ percent), although some areas of sparse grasses provided visibility of the upland surface and the slope of the road cut. No archeological materials were observed in these exposures. Given the locations of the two culverts, there is no chance that the proposed improvements will affect 41ML24 or any other cultural resources.

The south side of State Highway 6 near 41ML28 has been completely disturbed. The entire area is covered by parking lots and buildings. Other disturbances include a channelized drainage that traverses an equipment yard, probably at least sewer and water lines, and a gas pipeline and associated pumping station. Assuming 41ML28 is plotted correctly, it surely has been destroyed.

The south side of State Highway 6 near 41ML80 also has been substantially disturbed. Most of this area is within the large fenced McLennan County Detention Center, much of which is covered by buildings and parking lots. Other disturbances include gravel pits (some partly filled), railroad tracks, 0.5-1.0-m-deep ditches along the frontage road, buried utilities (water, sewer, and telephone), and railroad tracks south of the detention center. An undeveloped area just west of the detention center has been plowed recently, and the north edge of this plowed area, with excellent visibility, was examined; no archeological materials were observed. There is no chance that 41ML80 will be disturbed by improvements to the two culverts, which are beneath driveways into the detention center. If any part of the site ever extended this far north, it surely has been destroyed.

\section{Work Authorization 84: 41GM3}

Previously recorded site 41GM3 was investigated during survey for rehabilitation of FM 2 in Grimes County. The site is at the intersection of FM 2 and County Road 323. It apparently was first recorded by Harry Shafer, who noted that artifacts had been exposed by erosion of 1-2-ft-thick sands at the road intersection; a variety of Paleoindian points reportedly had been found there, probably by avocational archeologists. The site was revisited in 1986 by 
personnel with the Texas Archeological Survey of The University of Texas at Austin. Only the area within the TxDOT right of way was available for examination, and four shovel tests were placed there along the fence line northwest of the intersection. The tests yielded 10 tertiary chert flakes in sands up to $60 \mathrm{~cm}$ thick. In addition, a few flakes and mussel shell fragments were noted on the surface at the northeast corner of the intersection. The investigators concluded that most of the site probably lay on private land north of FM 2, both west and east of County Road 323.

The existing right of way at 41GM3 has been disturbed mostly by road cutting and secondarily by ditches and buried utilities. FM 2 is in a road cut that is ca. $2 \mathrm{~m}$ deep east of the intersection with County Road 323 and $0.5 \mathrm{~m}$ (south side) to $1.5 \mathrm{~m}$ (north side) deep west of the intersection. As a result, most of the right of way beyond the roads at the northwest, northeast, and southeast corners of the intersection consists of beveled slopes; intact portions of the hill remain as strips generally $4-10 \mathrm{~m}$ wide at the edges of the right of way in this area. The area southwest of the intersection appears to be essentially at grade, with minimal cutting. Ditches include the following: 1-m-deep and 4-m-wide ditches north and south of the road west of the intersection; 0.5-m-deep and 3-m-wide ditches north and south of the road east of the intersection; and ca. 0.5-m-deep ditches on both sides of County Road 323 south of FM 2 and away from the intersection. A buried phone line follows the north edge of the FM 2 right of way, and a second buried line crosses FM 2 ca. 30 m west of County Road 323. Surface visibility was generally poor, but areas of sparse grass, particularly along fence lines north of FM 2, and an unvegetated two-track road in the right of way southwest of the intersection did provide some surface visibility. A single chert flake was observed along the fence northwest of the intersection.

Survey of the right of way near 41GM3 involved walking over the area of the intersection and examining all areas of exposed ground surface and excavating four 1.7-m-wide trenches with a Gradall and three shovel tests. Trench 1 northeast of the intersection was $4 \mathrm{~m}$ long and exposed $15 \mathrm{~cm}$ of pale brown sand over $5+\mathrm{cm}$ of red sandy clay. Trenches 2 and 3 in the northwest quadrant of the intersection also were $4 \mathrm{~m}$ long and also exposed thin $(15-25 \mathrm{~cm})$ pale brown sand over red sandy clay or reddish yellow clayey sand with common iron-manganese mottles. The basal deposits are Miocene bedrock, and the overlying sands probably have been truncated to some extent by beveling of the road cut slopes. No archeological materials were seen in these trenches or in their backdirt, in spite of the fact that one flake was found on the surface near Trench 3 and artifacts were found in both areas during the 1986 revisit to the site. The fourth trench was placed southwest of the intersection. This trench was $7 \mathrm{~m}$ long and reached a depth of $1.4 \mathrm{~m}$ without encountering the basal clay. The trench exposed $35 \mathrm{~cm}$ of pale brown sand, over $25 \mathrm{~cm}$ of pale brown sand with thin dark reddish brown lamellae, over $80+\mathrm{cm}$ of reddish brown sand with dark reddish brown lamellae. No artifacts were observed in this trench or on the surface in the nearby two-track road. The three shovel tests were on the apparently intact north right of way edge west of CR 323. Shovel Test 5 was on the edge of the hill top, while Shovel Tests 6 and 7 were on the slope down to Rocky Creek to the west, with Shovel Test 7 being on the upland edge just south of a seep spring at the edge of the floodplain. All three tests encountered thin (14$23 \mathrm{~cm}$ ) hard brown sand with rare to common small gravels (chert, sandstone, and manganese) overlying reddish yellow clayey sand or dark reddish brown clayey sand. Shovel Test 6 yielded a single small tertiary flake from the upper sand, and Shovel Test 7 yielded a small, edge-modified chert chunk from the sand. It appears that sparse archeological remains are present in the thin sands within the right of way north of FM 2 , but based on the topography it seems likely that most of 41GM3 lies on the hill top north of the existing right of way and west of County Road 323. Though no artifacts were found northeast of the intersection during this survey, artifacts were observed there in 1986, and thus the site may well extend north beyond the right of way in this area too. Topography and the lack of artifacts on the surface or in Trench 4 suggest that the site does not extend south of FM 2.

Archeological remains associated with 41GM3 are present within the right of way of FM 2, but this part of the site has no capacity to contribute important information based on the sparseness of artifacts and other materials and the thinness of the sands. This part of the site is 
not eligible for listing in the National Register of Historic Places or designation as a State Archeological Landmark.

\section{Work Authorizations 89 and 99: Isolated Historic-age Well and Possible Cemetery}

Two cultural features that were not designated as archeological sites were investigated during an impact evaluation and survey for road reconstruction and curve realignment on FM 18 as it crosses the eastern city limits of Abilene. An abandoned well or cistern had been observed by TxDOT personnel within the right of way near the intersection of FM 18 and Elmdale Road. In addition, two headstones marking a possible cemetery had been noted within $15 \mathrm{~m}$ of the project right of way, suggesting that unmarked graves could be present in the project area.

The infilled well shaft or cistern is found within the FM 18 right of way approximately 20 m east of Elmdale Road and $5 \mathrm{~m}$ north of FM 18. The feature, approximately $1.5 \mathrm{~m}$ in diameter at its surface, is filled with wood and other debris and its margins overgrown in tall weeds. No lining was visible, but photographs taken by TxDOT personnel indicate its lower part is lined with bricks. No artifacts were observed on the surrounding ground surface. In all likelihood, this well or cistern was associated with a latenineteenth- or early-twentieth-century residence that once stood in the northeastern corner of the Elmdale Road-FM 18 intersection, perhaps in the yard area beyond the well-cistern where an occupied mobile home now sits. This isolated historic-age feature was not considered to warrant designation as an archeological site and does not offer to contribute important information.

The two headstones, inscribed "Sussanner Hale Died-1871" and "Annabella Hale 18651871 At Rest," are situated within a ca. $5 \times 5-\mathrm{m}$ plot outlined by rough field stones approximately $210 \mathrm{~m}$ east of Elmdale Road and $5 \mathrm{~m}$ north of the FM 18 right of way. The headstone inscribed "Sussanner Hale" is made of cut and polished granite, and the other appears to be of a cast composite stone. Both headstones are modern in appearance, as are the two cementfilled, small funerary urns that flank them. There is also a plastic cross decorated with plas- tic flowers and leaves present. In the southern side of the fieldstone-lined plot, in front of the six-year-old Annabella's stone, additional fieldstones have been set to mark a ca. $0.5 \times 3-\mathrm{m}$ area perhaps intended to represent the child's grave. No linear depressions of the sort often associated with grave shafts are apparent within the stone-lined plot, nor were depressions or other indications of burials observed in the surrounding area. According to TxDOT documents provided before this study, some members of the nearby Elmdale Baptist Church (built in 1924) report that the headstones were erected 40-50 years ago, although the person(s) responsible are not known.

Machine stripping with a Gradall was performed within the right of way by the possible burial plot to look for unmarked graves. The stripped area extended from the north edge of the road base fill section of FM 18 to the edge of the right of way, ca. $5 \mathrm{~m}$. The gravestones sit ca. $5 \mathrm{~m}$ north of the edge of the right of way and stripped area. The gravestones are oriented perpendicular to FM 18, and the stripped area extended $10 \mathrm{~m}$ on either side of a line drawn from the axis of the stones to FM 18. The stripped area was $20 \mathrm{~m}$ east-west by $5 \mathrm{~m}$ north-south. Approximately $10 \mathrm{~cm}$ of sediment were removed at a time by the bucket of the Gradall. The depth of excavation averaged $0.9 \mathrm{~m}$, ranging from 0.75 to $1.05 \mathrm{~m}$. The sediment was a brown silty clay loam with common limestone gravels (pea-sized to $5 \mathrm{~cm}$ ). A light reddish brown silty clay loam was observed at the bottom of the eastern half of the stripped area. Several medium to large mesquite roots cut through the stripped area. Excavation ended when, in the opinion of archeologists monitoring the trenching, any evidence of grave shafts, if present, would already have been obvious. Throughout the stripped area, the sediments were homogenous and showed no sign of disturbance. No evidence of graves or grave shafts was observed in the excavation.

The New Handbook of Texas reports that Elmdale had its origins in the early 1880 s as a stop along the Texas and Pacific Railroad. A oneroom school was built in 1895, and within seven years Baptist, Methodist, and Church of Christ congregations used the school house for their meetings (Odintz 1996:840). Whether the small community maintained a formal cemetery is not known, but the presence of the two stones just 
outside the FM 18 right of way suggests that this is possible despite the fact that the inscribed dates apparently predate Elmdale's foundation. Or, it is possible that these markers, apparently erected long after the deaths of Sussanner and Annabella Hale, do not mark actual graves but were placed simply to commemorate the deaths and perhaps interment of these individuals somewhere in this vicinity. In either case, there are no graves in the area that will be disturbed by reconstruction of FM 18.

\section{Work Authorizations 90 and 99: 41NL128}

Site 41NL128 was recorded during an impact evaluation and survey for construction of a new rest area along the eastbound lanes of Interstate Highway 20. The rest area will be placed on a ridge on the southern side of the interstate approximately $43 \mathrm{~km}$ west of Abilene and $18 \mathrm{~km}$ east of Sweetwater in northeastern Nolan County. The site extends across all of the proposed rest area, which is roughly trapezoidal in shape, ca. $640 \mathrm{~m}$ along its northern side and $420 \mathrm{~m}$ along its southern side. The southern limit of the project area is located approximately $244 \mathrm{~m}$ south of Interstate Highway 20.

The artifacts at 41NL128 indicate that it is a lithic procurement locale. Most visible because of their size are the 200+ tested cobbles, cores, and core fragments observed. Generally, 1 to 4 flakes have been taken off these pieces. At least 3 also show evidence of edge modification, making them expedient cobble tools. At least 200 flakes were observed, although these were more difficult to see and are probably more undernumerated than any artifact category. At least half of these are secondary flakes, with some preponderance of smaller tertiary flakes over primary flakes in the remaining numbers. At least 3 edge-modified flakes and 1 uniface were observed. More than 50 bifaces were also observed, most in the early stages of manufacture; only 3 to 5 are in the late stage of reduction and finishing. No temporally diagnostic artifacts were observed.

In addition to the artifacts, a large number of fist-sized, water-worn chert gravels are strewn throughout the project area, though in relatively fewer numbers on the ridge crest than on the more-gentle portions of the ridge slopes. These gravels often exhibit natural fracturing that mimics lithic reduction. The presence of gravels usually correlates with the presence of artifacts, though the gravels are almost always in greater number, except possibly in the dense artifact scatters observed on the west side of the unnamed tributary to Little Stink Creek, where both gravels and artifacts are numerous.

Three concentrations of what may be burned sandstone were observed on the western slope of the ridge near the center of the project area. The cores of these loose scatters are between 2 and $4 \mathrm{~m}$ in diameter, although additional burned rocks usually were observed up to $10 \mathrm{~m}$ away. Between 10 and 20 stones, generally approximately 8 to $10 \mathrm{~cm}$ in diameter, are associated with these scatters, and between 3 and 20 artifacts were observed. The soils associated with these scatters show no localized differences in color or texture that set them apart from the surrounding soils. Further, it was difficult to visually differentiate the possible burned rocks from the naturally weathered and fragmented sandstone bedrock that was often seen eroding out of gullies. This bedrock was also often brought to the surface in fragments through terrace construction. The possible burned rock features themselves are invariably associated with areas of sheetwash. If these do represent dispersed hearths, they seem to be purely surficial or redeposited.

Site 41NL128 extends across the entire 31acre project area and an unknown distance beyond. Although artifact types and relative frequencies are fairly consistent across the site, clear differences in artifact distribution, related to differences in topography, were observed. Few artifacts were observed on the ridge crest, regardless of visibility, and artifact density drops off significantly, if not altogether, in the southern $30 \mathrm{~m}$ of the ridge top. Visibility on the southern end of the ridge was poorer than on the northern end, however. The site appears to have been truncated on its northern end by the destruction of the northern end of the ridge during construction of the Interstate Highway 20 access road, and possibly Interstate Highway 20 itself. On the eastern slopes of the ridge, artifacts are most concentrated near the unnamed tributary to Little Stink Creek. Here, density consistently exceeds 10 artifacts per square meter. Although this tributary is just east of the project area, informal observation showed that 41 NL128 extends beyond the bounds of the 
project area, to at least the opposite bank of the tributary. Significant numbers of artifacts were seen on both sides of the tributary. Otherwise, artifacts are fairly evenly distributed on the eastern slopes of the ridge, rarely exceeding 10 per square meter. In contrast, artifacts on the western slopes of the ridge are distributed more patchily. Artifact scatters that measure up to $35 \mathrm{~m}$ across and with densities generally lower than 10 artifacts per square meter are separated by wide areas where few artifacts were observed. Many of these concentrations are downslope of deep erosional cuts through the ridge slope, although examination of the profiles of at least six of these cuts revealed no evidence of buried archeological materials. There also are some areas of artifact concentration along the slope immediately adjacent to the ridge top on the western side.

The many erosional cuts up to $1 \mathrm{~m}$ deep provided ample opportunity for subsurface investigation and made shovel testing unnecessary. Sediments up to $40 \mathrm{~cm}$ deep were observed in places, although generally they are no more than $20 \mathrm{~cm}$ thick. No evidence of colluvial infilling or buried archeological materials was observed in these gullies.

The geologic setting as well as the quantities and types of artifacts observed at 41NL128 suggest it represents the remains of a lithic procurement locale. The abundant chert gravels found extensively across the ridge and especially on its eastern and western slopes provided a resource for prehistoric peoples seeking materials to produce stone tools. Tested raw materials of poor quality, cores that have had the needed flakes already removed, and manufacturing failures and discards represent the bulk of the assemblage. The quality and quantity of artifacts found on the ridge and slopes suggest repeated exploitation of these resources over a long period, but the dearth of habitation features and tools suggests that occupation of the site was at best ephemeral at any given time.

Site 41 NL128 is a surface scatter of lithic artifacts. No evidence for buried cultural deposits that could contain temporally discrete cultural remains and answer questions of significance about prehistory was found. Also, no clear evidence for occupational features was observed on the surface. Erosion has heavily damaged this upland site. Hence, this site appears to be ineligible for listing in the National
Register of Historic Places or designation as a State Archeological Landmark.

\section{Work Authorization 91: 41 WM235 and 41 WM774}

Areas near previously recorded sites 41WM235 and 41WM774 were investigated during an impact evaluation for adding lanes to both RM 1431 and FM 734 at their intersection in Williamson County. Site 41WM235, the Wilson-Leonard site, is situated on the west side of Brushy Creek immediately south of RM 1431 at the eastern end of the project area. This National Register-eligible prehistoric site was the scene of extensive data recovery excavations in 1982-1984 and 1992-1993 (Collins 1998). The second site, 41WM774, recorded by TxDOT personnel before the construction of FM 734, is a scatter of prehistoric artifacts (lithic debitage, flake tools, and biface fragments) in thin sediments atop exposed limestone bedrock overlooking an unnamed tributary to Brushy Creek in the southern part of the project area. Though plotted south of the tributary on the west side of FM 734, the site probably was on the north side of the creek, judging from the information in the site form.

All of the project area has been disturbed by activities associated with the recent construction of RM 1431 and FM 734, including road cutting, the construction of fill sections, and the construction of drainage structures, as well as by the placement of buried utilities. A small section of the face of the Brushy Creek terrace south of RM 1431 has been exposed by erosion. Though this terrace contains the Wilson-Leonard site (41WM235), no artifacts were seen in this exposure or on the terrace surface to the west. Over most of this area, RM 1431 is nearly at grade with the Holocene terrace containing the site, with disturbances in the existing right of way including a shallow ditch and a buried telephone line. Project plans show that this Holocene terrace will be disturbed minimally through widening of the road by a few feet, extending the shoulder southward to encompass the current roadside ditch, and doing some minor new ditch grading (to a depth of a foot or less) on the western part of the terrace near the base of the valley wall. Given that the Wilson-Leonard site extends deep into this terrace and that the most significant remains there relate to the early oc- 
cupations at depths below ca. $1.5 \mathrm{~m}$ (Michael B. Collins, personal communication 2003), it is unlikely that the minor surface modifications resulting from this project will affect the site adversely.

In the area of $41 \mathrm{WM} 774$, fill sections $2-5 \mathrm{~m}$ thick occupy the existing right of way, except for ca. 30-40 $\mathrm{m}$ where a bridge spans the narrow floodplain of the Brushy Creek tributary. Other disturbances in this area include buried telephone lines and water and sewer lines along the west side of FM 734. No evidence of the site was seen on the surface in the existing right of way, and it is likely that whatever part of it that was in the right of way has been destroyed or covered over by the large fill section in this area.

\section{Work Authorization 91: 41TV1134 and 41TV1135}

Areas adjacent to previously recorded sites 41TV1134 and 41TV1135 were investigated during an impact evaluation for replacing the existing Yager Lane bridge over Interstate Highway 35, completing Harris Ridge Parkway east of Interstate Highway 35, and reconstructing the Interstate Highway 35 frontage roads north and south of the existing Yager Lane bridge in Travis County. Both sites are east of Interstate Highway 35 and north of Yager Lane and were recorded during a 1985 survey of a subdivision that was never developed (Standifer and Freeman 1985). Site 41TV1134 is a large multicomponent site on the east side of a tributary to Walnut Creek; it is abutted on the south side by Yager Lane and on the southwest side by the existing Interstate Highway 35 right of way. The prehistoric component is a ca. $250 \times 250-\mathrm{m}$ lithic scatter containing tertiary flakes, biface fragments, burned rocks, and two dart point fragments exposed on the surface. Sparse artifacts were found in 6 of the 10 shovel tests excavated on the site, mostly at depths of less than $25 \mathrm{~cm}$ in thin soils atop bedrock. The prehistoric component of 41TV1134 was considered ineligible for National Register listing or designation as a State Archeological Landmark because it had been disturbed by historic activities.

The historic-age component, however, was considered significant because of its association with Elizabeth Corzine, who settled there with her family and slaves in the late $1850 \mathrm{~s}$, and
John Dillingham, a prominent rancher who lived at the site from 1871 till 1917. The historic-age component covers an area of ca. $125 \times 74 \mathrm{~m}$ and includes the remains of a house, the surrounding yard area, and associated outbuildings and stock pens. The house was no longer standing in 1985, but a cut-stone chimney probably associated with construction of the original house in the mid 1800s was present, as were foundation elements relating to later additions. The house was added on to several times and apparently was occupied until it burned sometime after 1935. Also present were the following: corrugated tin, lumber, and rock alignments probably representing the remains of a barn; an extant chicken shed; an extant two-hole outhouse; an extant two-room, board-and-batten structure with a false front; two rock-lined wells or cisterns; a plastered cistern; various landscaping features, including four fish ponds; and a number of stock pens.

Site 41TV1135 is a large, thin, surficial prehistoric and historic artifact scatter located on the west side of the Walnut Creek tributary; it is abutted on the southwest side by the existing Interstate Highway 35 right of way. It occupies a ca. $100-\mathrm{m}$-wide strip that extends for ca. $300 \mathrm{~m}$ along the creek. Historic-age artifacts were observed only in the sides of an erosional feature in the southern part of the site and included purple glass, whiteware sherds, a flat bastard file, and various rusted metal items. The erosional feature appeared to be an old road bed, and the artifacts appeared to be trash deposited along this road, perhaps from 41TV1134 just to the east. The prehistoric component consists of several scatters of lithic debitage exposed in eroded areas; one of these scatters also contains some burned limestone, as well as a ca. 1.0x1.5-m burned rock cluster exposed on the surface. Seven shovel tests were dug at 41TV1135, and three yielded sparse prehistoric materials at depths of less than $40 \mathrm{~cm}$. This site was considered ineligible for National Register listing or State Archeological Landmark designation because it is largely surficial.

The impact evaluation included inspecting all areas of existing right of way adjacent to these sites. The existing right of way along Interstate Highway 35 and Yager Lane has been thoroughly disturbed by fill sections, road cutting, ditches, buried utilities, and earthmoving, 
as well as road construction. Generally, Interstate Highway 35 and its frontage roads are below grade along much of the project area, and hence road cuts 1-3 $\mathrm{m}$ deep are common. Also common are ditches $0.5-1.0 \mathrm{~m}$ deep along the frontage roads and parts of Yager Lane; some of these have been lined with concrete and feed into storm sewers. Several buried utilities are present, including water and wastewater lines and telephone lines at both edges of the Interstate Highway 35 right of way and probably storm sewers and electric lines. The narrow strip of new right of way east of Interstate Highway 35 and north of Yager Lane, in the area of 41TV1135, is less disturbed because it occupies a vacant pasture. Parts of the new right of way needed to extend Harris Ridge Parkway, in the area of 41TV1134, appear to have been disturbed by construction of the completed part of this road, earthmoving associated with predevelopment activities on this tract, and placement of buried utilities; because access to this area was not available, however, the full extent of these disturbances could not be determined.

Surface visibility was generally poor ( $<10$ percent) because impervious cover and dense vegetation in most of the areas examined, but no archeological remains were observed in the existing right of way or along the edges of the areas of new right of way near the two sites. Most of the proposed project has no potential to disturb cultural resources that are eligible for listing in the National Register of Historic Places or designation as State Archeological Landmarks. The strip of new right of way east of the frontage road and north of Yager Lane has no potential for archeological remains in good context. This area was surveyed in 1985 (Standifer and Freeman 1985), and 41TV1135 was found to extend into the southern part of it. The site was assessed as ineligible at that time based on its largely surficial nature, and that assessment is still appropriate today. Completion of Harris Ridge Parkway westward on new right of way to connect with the new interchange will affect 41TV1134, but because of a lack of right of entry, the full nature and extent of these disturbances could not be determined. Although the prehistoric component was not considered significant in 1985 based on its largely surficial nature and disturbed condition, the historic-age component was considered eligible for National
Register listing. Based on an overlay of the site sketch map on modern maps and aerial photographs, the core part of this historic-age component is at the east end of the new right of way, just west and north of the completed section of Harris Ridge Parkway. The main part of this historic-age component lies in the wooded area north of the proposed new right of way, and hence it will not be disturbed by the project. Once right of entry to the new right of way has been obtained, however, an impact evaluation should be done to confirm this.

\section{Work Authorization 92: 41LE325}

Site 41LE325 was recorded during survey for replacement of the bridge on County Road 216 at Sandy Creek in Lee County. Four trenches and one shovel test were placed on a high terrace $\left(\mathrm{T}_{1}\right)$ west of the road and north of Sandy Creek. This terrace sits ca. 7-8 $\mathrm{m}$ above the stream channel. Trench 1 was placed ca. $10 \mathrm{~m}$ from the terrace edge. This trench was ca. $1.7 \mathrm{~m}$ deep, $1 \mathrm{~m}$ wide, and $9 \mathrm{~m}$ long. Four distinct sediment zones were visible. The upper $10 \mathrm{~cm}$ consisted of a sandy silty clay Ap horizon (10YR 3/3) with moderate granular structure. Located at ca. $10-90 \mathrm{~cm}$, Zone 2 contained a silty sandy alluvium (10YR 4/3) with no detectable pedogenic processes. Cultural materials encountered within this zone consisted of chert flakes and cores, some of which were thermally altered. Zone 3 (ca. 90-134 cm) consisted of a compact silty clay (10YR 4/8) containing no cultural materials. A second sandy alluvial deposit was present at $134-170 \mathrm{~cm}$. No cultural materials were encountered in this zone.

To investigate the stratigraphic context of the cultural materials, Shovel Test 1 was placed $2 \mathrm{~m}$ north of Trench 1 . Excavation to a depth of $100 \mathrm{~cm}$ and penetrating the upper $10 \mathrm{~cm}$ of Zone 3 confirmed that all cultural materials are restricted to Zones 1 and 2. Fifteen lithic artifacts were recovered from the upper $80 \mathrm{~cm}$ : 2 flakes and 4 chert chunks at $0-20 \mathrm{~cm} ; 2$ flakes and 4 chert chunks at 20-40 cm; 1 flake and 1 core at 40-60 $\mathrm{cm}$; and 1 flake at $60-80 \mathrm{~cm}$. Trenches $2-$ 4 were spaced ca. $10 \mathrm{~m}$ apart to the north of Trench 1; no cultural materials were encountered in any of these trenches.

The cultural materials observed in Trench 1 and recovered from Shovel Test 1 were 
recorded as 41LE325. This site appears to be a moderate-density scatter of lithic artifacts restricted to the upper $80-90 \mathrm{~cm}$ of the $\mathrm{T}_{1}$ terrace north of the creek. The site is small, extending no more than ca. $15 \mathrm{~m}$ north-south based on the absence of artifacts in Trench 2 to the north and the cutbanks of Sandy Creek to the south. It is not known if the site extends east of CR 216 or west beyond the proposed right of way. Based on topography, the site is at one of the lowest points on the terrace, and this probably has allowed sheetwash to transport sands to this location from higher on the landscape to the north. Alluvial processes probably are also responsible for deposition of the sandy deposits. No evidence of cultural features, datable materials, or faunal remains was found in Trench 1 or Shovel Test 1.

Site 41LE325 appears to have little potential to contain important information based on the vertically scattered nature of the artifacts (i.e., they do not occur in discrete zones), the apparent lack of cultural features, the lack of charcoal or other datable materials, and the lack of materials such as faunal remains. Given these characteristics, it would be impossible to identify isolable, datable, and interpretable components. Hence, 41LE325 is considered ineligible for listing in the National Register of Historic Places and designation as a State Archeological Landmark.

\section{Work Authorization 93: 41HM46}

Site 41HM46 was recorded during survey for replacement of the bridge on County Road 294 at the Leon River in Hamilton County. The investigations consisted of the excavation of two backhoe trenches on the $\mathrm{T}_{1}$ surface on the south side of the river. Trench 1 was placed ca. $15 \mathrm{~m}$ south of the scarp separating the $\mathrm{T}_{1}$ and $\mathrm{T}_{0}$ surfaces. The trench was $2.2 \mathrm{~m}$ deep, $1.3 \mathrm{~m}$ wide, and $7.0 \mathrm{~m}$ long. The trench lacked cultural materials and displayed a profile consisting of sediments that are slightly modified (A-Bw-C profile). Trench 2 was placed ca. $12 \mathrm{~m}$ south of Trench 1 . The trench was $1.75 \mathrm{~m}$ deep, $1.3 \mathrm{~m}$ wide, and $7.0 \mathrm{~m}$ long. The trench profile revealed a drape of recent alluvium overlying a more pedogenically modified alluvial unit (A-Bw-2Ab profile). The A horizon $(0-28 \mathrm{~cm})$ is a very dark grayish brown (10YR 3/2) silty clay loam, and the Bw horizon $(28-90 \mathrm{~cm})$ is a dark grayish brown (10YR 4/2) silty clay loam. The underlying $2 \mathrm{Ab}$ horizon $(90-175+\mathrm{cm})$ is a very dark gray (10YR 3/1) clay loam. The soil is cumulic in nature, possesses a moderate medium blocky angular structure, and is ca. $1 \mathrm{~m}$ thick based on its full exposure in cutbank profiles outside the project area. Cultural materials were observed throughout the buried soil and across the adjacent backdirt pile. The two trench profiles reveal that at least two alluvial units underlie the $\mathrm{T}_{1}$ surface on the south side of the river within the project area. The more-recent deposits observed in Trench 1 are laterally inset to and draped over the pedogenically modified fill observed at $90-175+\mathrm{cm}$ in Trench 2 . The buried cumulic soil (2Ab horizon) observed in Trench 2 is similar to the Leon River paleosol identified downstream at Fort Hood (see Mehalchick et al. 1999, 2000) in its pedogenic characteristics and geomorphic position.

The cultural materials observed in the buried soil of Trench 2 were recorded as 41HM46. Site 41HM46 represents a prehistoric open campsite. Its dimensions could not be determined based on the trenching, but it was considered likely that the site extends beyond the boundaries of the project area, as the $\mathrm{T}_{1}$ terrace surface is extensive, and the buried soil is present in cutbank exposures outside the project area. The part of the site within the project area is at least $45 \mathrm{~m}$ north-south by $28 \mathrm{~m}$ eastwest. The cultural deposits at 41HM46 are at least $85 \mathrm{~cm}$ thick based on observations made in Trench 2. The top of the cultural deposits is $90 \mathrm{~cm}$ below the surface. Cultural materials observed consist of burned rocks, pieces of charcoal, and freshwater mussel shells. No diagnostic artifacts or intact features were observed. Given the cumulic nature of the paleosol containing $41 \mathrm{HM} 46$, the site appears to have the potential to contain discrete assemblages. If so, it could contribute important information and be eligible for listing in the National Register of Historic Places and designation as a State Archeological Landmark.

\section{Work Authorization 95: 41FY420}

Part of previously recorded site 41FY420 was investigated during survey for rehabilitation of FM 154 in Fayette County. The site is 
recorded just west of FM 154 on a terrace north of Buckners Creek. Lithic debitage and burned rocks were noted on the surface during survey of the FM 154 right of way by TxDOT personnel; based on the extent of the terrace landform, it was surmised that most of the site lay west of the right of way.

Survey consisted of visual inspection of the existing right of way for ca. $80 \mathrm{~m}$ north of Buckners Creek, accompanied by excavation of six backhoe trenches and one shovel test. The east side of the road contains fill sections that slope eastward and abut a fence line marking private property. The lack of undisturbed deposits in this area precluded subsurface testing. All subsurface tests were placed along the west side of the road. The shovel test was placed just inside the right of way near the eastern terminus of $41 \mathrm{FY} 420$; the shovel test was stopped at approximately $40 \mathrm{~cm}$ because there was an impenetrable gravelly clayey construction fill present. This small probe yielded only modern debris consisting of glass and plastic. Two trenches were placed on the floodplain north of Buckners Creek, and four were placed along the footslope of the terrace containing 41FY420. Burned rocks or chert flakes were observed in three trenches, all of which were located on or adjacent to $41 \mathrm{FY} 420$.

Most of the subsurface tests exposed highly disturbed deposits and very active and diverse depositional processes within the project area. The deposits on the present-day floodplain, exposed in Trenches 1 and 2, consisted of recent alluvium and construction fill; no cultural materials were found. Trench 3 was placed $10 \mathrm{~m}$ north of Trench 2 and $6 \mathrm{~m}$ west of the road within the existing right of way. It contained three distinct sediment zones. Zone 1 at $0-30 \mathrm{~cm}$ below the ground surface consisted of dry, friable, dark sandy silty clay containing numerous roots and rootlets. Moderate pedogenic processes have altered this upper zone. Historicage glass and other debris were lightly scattered throughout this zone. A single large burned rock was present at ca. $25 \mathrm{~cm}$ in the southeast corner of this trench. Zone 1 is a mixture of recent alluvial deposits and colluvium eroding downslope from the terrace containing 41FY420. Zone $2(30-130 \mathrm{~cm})$ consisted of a deep alluvial sandy clayey silt containing several pockets of compact clay (10YR 5/1). No cultural materials were recorded in this zone. Zone 3 was limited to the lower $40 \mathrm{~cm}(130-170 \mathrm{~cm})$ and consisted of decomposing sandstone gravels in a sandy silty clay matrix (10YR 4/2). This zone was similar to the lower construction fill zone in Trench 2. No cultural materials were recovered from this zone.

Trench 4 was placed $10 \mathrm{~m}$ north of Trench 3 and ca. $8 \mathrm{~m}$ west of the road; it was ca. $8 \mathrm{~m}$ long and $1.6 \mathrm{~m}$ deep. At the time of survey, no right of way fence line was present west of FM 154, and it was the judgment of the project archeologist and TxDOT staff present onsite that Trench 4 was within the existing right of way. But after excavation and documentation of Trench 4, it was determined that the trench was actually $1.5 \mathrm{~m}$ west of the right of way. Trench 4 was at the apex of the western slope of the terrace containing 41FY420 and revealed intact buried cultural deposits. Three distinct zones were recorded in this trench, of which two contained dense cultural materials. Zone 1 was at $0-30 \mathrm{~cm}$ and consisted of dry, friable, sandy silt with a few gravel clasts scattered throughout. This upper zone was the only deposit that did not contain cultural materials. Zone $2(30-100 \mathrm{~cm})$ consisted of very sandy clayey silt containing a dense lens of burned rocks and large chert flakes. This lens of burned rocks was encountered at various depths throughout the extent of the trench. At the south end, the lens was ca. $45 \mathrm{~cm}$ below the ground surface. The lens sloped down toward the north end of the trench where there was a dense grouping of large burned rocks that appeared to be situated on a relict surface (ca. $1.40 \mathrm{~m}$ below the ground surface). This grouping of burned rocks was situated in a dark clayey matrix associated with Zone 3. Zone 3 was at $100-160 \mathrm{~cm}$ below the surface and consisted of a sandy silty clay containing no gravel clasts. Cultural materials were limited to the burned rocks in the northern end of the trench.

Trench 5 was placed in the existing right of way approximately $10 \mathrm{~m}$ north of Trench 4 and was $7 \mathrm{~m}$ in length and $1.54 \mathrm{~m}$ deep. Three sediment zones were observed in this trench. Zone 1 was located at $0-20 \mathrm{~cm}$ below the surface and consisted of a sticky, gravelly, sandy silty clay alluvium. Zone 2 (20-60 $\mathrm{cm}$ below the surface) consisted of a hard, compact, silty clay. Zone 3 was a buried alluvial deposit consisting of a light (10YR 4/1), soft, clayey sandy silt. No cultural materials were recorded in this trench. These stratigraphic zones revealed that the cultural 
deposits associated with 41FY420 do not extend this far north in the right of way.

Trench 6 was placed just east of Trench 4 within the existing right of way. Three stratigraphic zones were exposed in this trench. Zone 1 was located at $0-80 \mathrm{~cm}$ below the ground surface and consisted of heavily compacted construction fill. This fill contained various sizes of sandstone and limestone coarse gravels. Zone 2 $(80-88 \mathrm{~cm})$ consisted of a hard, compact, silty clay with a few isolated small burned rocks in the east wall; these burned rocks probably had been displaced from 41FY420 upslope to the east. Zone 3 at $88-177 \mathrm{~cm}$ below the ground surface consisted of a compact, moist, silty clay. It was similar to Zone 3 but contained more clay. No cultural materials were recorded in this zone.

Intact deposits associated with 41FY420 are present just outside the right of way, as demonstrated by the dense cultural materials exposed in Trench 4 . This site is positioned on a terrace high on the landscape above the present-day stream channel. Erosional processes continue to affect the landform, shedding colluvium and cultural materials and depositing them downslope. The eastern site boundary is located ca. $1.5 \mathrm{~m}$ west of the road fill sections and approximately $8 \mathrm{~m}$ west of the road way. East of Trench 4, within the existing right of way, no intact cultural deposits were encountered. In addition, north of 41FY420 the presence of recently deposited alluvium marks the site boundary. While the part of the site west of the FM 154 right of way could contain important information, that is not the case for the part within the existing right of way. This part is thoroughly disturbed and is not eligible for listing in the National Register of Historic Places or designation as a State Archeological Landmark.

\section{Work Authorization 97: 41BL1214}

Site 41BL1214 was recorded during survey for replacement of the bridge on State Highway 95 at the Little River in Bell County. Trenches 1-9 and Shovel Tests 1 and 2 were placed in proposed new right of way on the floodplain south of the Little River and east of the highway. Trenches 1-3 placed ca. 10-70 m south of the river did not contain any cultural materials. Trenches 4-9 farther to the south all contained cultural materials and exposed similar stratigraphic profiles consisting of four distinct sediment zones (except that Zone 4 was not reached in Trench 4, which was $150 \mathrm{~cm}$ deep). Zone 1, which ranged from $10 \mathrm{~cm}$ thick in Trench 7 to $30 \mathrm{~cm}$ thick in Trenches 5 and 6 , consisted of a silty very clayey A horizon (10YR 4/4). Zone 2 , ranging from $30 \mathrm{~cm}$ thick in Trench 8 to $70 \mathrm{~cm}$ thick in Trenches 6 and 9, consisted of a dark sandy silty clay (10YR 4/2 to $10 \mathrm{YR} 4 / 3$ ). Zone 3 ranged from ca. $50 \mathrm{~cm}$ thick in Trenches 7 and 9 to $96 \mathrm{~cm}$ thick in Trench 8 and consisted of a sandy silty clay (10YR 4/2). Zone 4 was encountered as shallow as $90 \mathrm{~cm}$ in Trench 7 and as deep as $160 \mathrm{~cm}$ in Trenches 5 and 6 and extended to the bottom of Trenches 5-9 at 172$220 \mathrm{~cm}$; it consisted of a dense compact silty clay (10YR 4/2). The cultural materials found in Trenches 4-9 consisted of sparse chert debitage intermixed with more-numerous mussel shells and scattered burned rocks. These materials were seen at $60-140 \mathrm{~cm}$ in Trench 4 (Zones 2 and 3), 89-202 cm in Trench 5 (Zones 3 and 4), $60-220 \mathrm{~cm}$ in Trench 6 (Zones 2-4), 63-140 cm in Trench 7 (Zones 2-4), 70-170 cm in Trench 8 (Zones 3 and 4), and $90-183 \mathrm{~cm}$ in Trench 9 (Zones 3 and 4). In addition, four possible cultural features were encountered in Trenches 4 , 5 , and 9 . Trench 4 contained two of the four features. Feature 1 was found in the trench wall ca. $64 \mathrm{~cm}$ below the ground surface. This cluster consisted of three small (ca. 5-6 cm) burned rock fragments. No other cultural materials were observed. Feature 2 was uncovered in the trench floor at ca. $70 \mathrm{~cm}$ below the ground surface. It consisted of a 90x90-cm, irregularly shaped cluster of 15-20+ lightly burned limestone cobbles. The rocks averaged $10-20 \mathrm{~cm}$ in length. Mussel shells were abundant in the surrounding sediment. There was a dense cluster of gastropod shells present in the center of the burned rocks. No other cultural materials were observed. Feature 3 was found ca. $185 \mathrm{~cm}$ below the ground surface in Trench 5 . It consisted of a light charcoal stain associated with four small burned rocks. No other cultural materials were associated with this feature. Feature 4 was encountered ca. $183 \mathrm{~cm}$ below the ground surface in Trench 9. This feature consisted of seven burned rocks scattered across the floor of the trench. Abundant charcoal flecks were loosely scattered across the trench. No other cultural materials were encountered. Shovel Tests 1 and 2 were placed along Trench 4 in an effort to 
obtain a controlled sample of cultural materials. Each of these tests were excavated to $100 \mathrm{~cm}$ below the ground surface, but no cultural materials were found.

The cultural materials observed in Trenches 4-9 were recorded as 41BL1214. This site represents a floodplain occupation possibly focused on the procurement of aquatic resources from Little River. Its dimensions are not known, but the site certainly extends beyond the boundaries of the project area to the east and probably to the west; it probably also extends south into the unsurveyed part of the current project area (i.e., the areas where right of entry and permission to trench had not been obtained). At the least, the site extends the width of the new right of way (ca. $11 \mathrm{~m}$ ) and ca. $200 \mathrm{~m}$ north-south. The cultural deposits associated with 41BL1214 are at least $160 \mathrm{~cm}$ thick based on observations from backhoe trenches. Cultural materials observed include burned rocks, freshwater mussel shells, charcoal, and lithic artifacts. Four possible cultural features were exposed during this survey. No temporally diagnostic artifacts were recovered. Based on its context, the apparent presence of intact features, and the presence of datable charcoal, 41BL1214 was judged to have the potential to contain contain important archeological information and be eligible for listing in the National Register and designation as a State Archeological Landmark.

\section{Work Authorization 99: 41SN79}

Site 41SN79 was recorded during survey for replacement of the County Road 110 bridge over Croton Creek in Stonewall County. Cultural remains were observed on the surface along the margin of the upland terrace in the northwest quadrant of the project area. Initially, the site was identified by the presence of several flakes, a biface, and possible burned rocks scattered across the surface of the landform. Intensive pedestrian survey was subsequently conducted at 3-m intervals but revealed little additional material. Visibility was invariably greater than 50 percent. Total artifacts counted included 6 flakes (all tertiary, manufactured from chert), 1 distal biface fragment, 2 bifacially modified tools, and 30+ possible burned rocks. The burned rocks were a combination of quartzite and limestone, both complete and fragmented. It was difficult to differentiate potential burned rocks from the many natural gravels of similar size and material that are strewn across the site. An 80 -cm-diameter concentration of 30 of these possible burned rocks was recorded in the northcentral portion of the site area. The matrix of the concentration was indistinguishable from that found on the surface throughout the remainder of the site. No temporally diagnostic artifacts were observed. Two shovel tests were excavated to a depth of $80 \mathrm{~cm}$ and showed similar profiles. From 0 to $60 \mathrm{~cm}$, a dark reddish brown sandy loam with common small gravels was observed. From 60 to $80 \mathrm{~cm}$, a reddish brown clay loam with small limestone gravels was observed. No artifacts were found in either test. Examination of the ca. 3-m-deep County Road 110 cut through this landform also did not reveal any cultural remains or potential for buried deposits.

The site covers an area of $14 \times 45 \mathrm{~m}$, but the mapped limits to the north and west are constrained by the project area limits, and the site likely extends farther in these directions (although there is an old possible channel cut less than $20 \mathrm{~m}$ north of the project limits). To the east, the site has been truncated by the County Road 110 road cut through this landform. Pedestrian survey on the terrace east of the road did not reveal any cultural remains, nor did that part of the terrace show any of the numerous surface gravels visible at 41SN79. It seems likely the site originally did not extend that far east. To the south, artifacts associated with the site have moved only partly down the eroded edge of the terrace slope, and no artifacts were observed on the floodplain below where visibility was up to 75 percent.

Site 41SN79 is a low-density surface scatter of lithic debris, likely representing a prehistoric open campsite. The currently mapped portion of the site is small in area, constrained to a circumscribed portion of possible new right of way west of the road. No temporally diagnostic artifacts and no intact features were observed. Shovel testing and road cut observations indicate that the site lacks subsurface cultural deposits that could contain temporally discrete cultural remains. Therefore, 41SN79 lacks the capacity to contribute important information and is ineligible for listing in the National Register of Historic Places or designation as a State Archeological Landmark. 


\section{Patterns in Site Distributions}

The 29 archeological sites observed occupy a variety of topographic settings. The 5 historicage sites are mostly in upland settings, with 3 house sites (41BL1155, 41TV2022, and 41TV2023) on Cretaceous uplands in Bell and Travis Counties and one cemetery (41FA69) in Eocene uplands in Falls County. Another house site (41ML269) occupies a Pleistocene terrace on the South Bosque River in McLennan County.

Twenty of the 24 prehistoric sites are close to water sources, with 40 percent of these being in Holocene alluvium and 60 percent occupying Pleistocene terraces or upland margins overlooking creeks or rivers. The Holocene alluvial sites are 41WS56 on Catlett Creek in Wise County, 41CJ93 and 41CJ94 on Copperas Creek in Comanche County, 41BU72 on Cedar Creek in Burleson County, 41HI292 on a tributary to the Navasota River in Hill County, 41LE325 on Sandy Creek in Lee County, 41HM46 on the Leon River in Hamilton County, and 41BL1214 on the Little River in Bell County. These 8 sites are spread across five of the seven districts included in this project (Austin, Brownwood, Bryan, Fort Worth, and Waco).

The 3 prehistoric sites that are on Pleistocene terraces near water sources are 41GZ210 on Sandy Fork Creek in Gonzales County (Yoakum District) and 41BU51 and $41 B U 75$ on the Brazos River in Burleson County (Bryan District). The 9 sites that are on upland margins close to streams are 41MA26 on Iron Creek in Madison County, 41DW275 on the Guadalupe River in DeWitt County, 41BU54 on Davisdon Creek in Burleson County, 41SV152 on a tributary to the Brazos River in Somervell County, 41FS92 on Bull Creek in Fisher County, 41KT32 on the Salt Fork of the Brazos River in Kent County, 41GM3 on Rocky Creek in Grimes County, 41FY420 on Buckners Creek in Fayette County, and 41SN79 on Croton Creek in Stonewall County. These 9 sites are in the Abilene, Bryan, Fort Worth, and Yoakum Districts. The 4 prehistoric sites that are not close to water sources are 41WM646, 41WM1008, and 41WM1009 in Williamson County (Austin District) and 41NL128 in Nolan County (Abilene District). All 4 are in upland settings where cherts occur naturally.

\section{UTILITY OF EXISTING METHODS}

The methods employed for Impact Evaluations and Surveys appear to be consistent with a reasonable and good-faith effort to comply with federal and state laws governing identification of archeological sites that are eligible for listing in the National Register of Historic Places or designation as State Archeological Landmarks. The level of effort typically required to complete an Impact Evaluation (e.g., 1-2 hours for a single bridge replacement) seems appropriate given the intent of this type of work and the generally small project areas. When Impact Evaluations can quickly separate those project areas for which survey is truly a good idea from those in which sites are very unlikely or almost surely disturbed, they are an efficient and relatively inexpensive measure to guard against the loss of important archeological data.

The levels of effort spent on Surveys and the amounts of work done (i.e., numbers of trenches and shovel tests) also seem appropriate given the sizes of the project areas, although the amount of work can vary based on factors other than project size (e.g., backhoe accessibility, depth to ground water, landowner permission to trench, extent of disturbance, and number and location of buried utilities that must be avoided during trenching). The work done on these surveys easily meets or exceeds the Texas Historical Commission's archeological survey standards, except in some cases in which only trenches were dug. This was the case in some floodplain settings where shovel testing was considered ineffective and inefficient because of the thickness of the alluvium or because of dense clay soils. In these cases, the much greater subsurface visibility afforded by the backhoe trenches and the fact that the number of trenches well exceeds the minimum required compensates for the lack of shovel testing.

\section{EVALUATION OF THE NEED FOR SURVEY}

This final section deals with the related topics of identifying patterns of existing conditions that affect the need for survey and predicting when field inspections are and are not needed. Based on the work done during this project, these issues can be addressed by looking at how 
often survey was deemed warranted when an Impact Evaluation was completed and the factors that contributed to these evaluations, as well as how often potentially significant archeological sites were found during surveys.

Of the 94 Impact Evaluations done, 16 led to recommendations that survey was needed before construction. Twelve of these projects involved the acquisition of new right of way, with the amount varying from 0.1 to 80.0 acres. Eleven of the 12 with new right of way were in settings with thick Holocene alluvium and thus the potential for buried archeological sites in good context. The twelfth was in an upland setting with an extensive archeological site visible on the surface, and survey was needed to document this site. In 1 of the other 4 cases, no new right of way was required, but survey was recommended because potentially important archeological sites were observed in thick Holocene alluvium. In another with no new right of way, a possible historic-age cemetery was observed adjoining the existing right of way, and survey to look for unmarked graves was recommended. In the other 2 cases, it was unknown if new right of way was required, but both had thick Holocene alluvium and areas of existing right of way with the potential for buried sites, and survey was recommended (in both, survey also was recommended if new right of way was to be acquired). Seven other cases in which it also was unknown whether new right of way would be needed but in which thick Holocene alluvium was present resulted in recommendations for survey only in areas of new right of way, with the existing rights of way being too disturbed to contain important sites. In total, 21 of the 23 Impact Evaluations for which survey was considered warranted (or potentially so, depending on the acquisition of new right of way) were in areas with thick Holocene alluvium and the potential for buried sites.

The other 71 Impact Evaluations resulted in recommendations that no survey be required before construction based on the limited potential for sites with good integrity. Survey was not warranted for four main reasons. First, 49 of these Transportation Activities will require no new rights of way or easements, with all construction-related disturbances restricted to existing, already-disturbed rights of way. Second, in 14 of the cases in which new right of way could be required, disturbance is so extensive that there is no potential for sites with good integrity. Third, 6 cases in which new right of way could be required are restricted to upland landforms where there is no chance for buried sites. Fourth, in 2 cases in which new right of way could be required, surface and subsurface exposures were adequate to determine that archeological sites are not present.

The results of this project are consistent with the traditional thought that Transportation Activities that do not involve new right of way, particularly when they are in uplands or areas with thin Holocene deposits, are likely to be poor candidates for productive archeological survey. Beyond this, the frequent inability to predetermine where significant existing disturbances and thin (or no) alluvium might exist in project areas suggests that Impact Evaluations will continue to be the prudent choice on certain kinds of Transportation Activities, particularly those where significant accumulations of Holocene sediments could be present and those that are in settings (e.g., valley margins or proximity to known sites) where sites are likely, whether new right of way is involved or not.

Of the 88 Surveys done under this contract, 22 investigated a total of 17 newly recorded and 9 previously recorded sites; 20 of the sites are prehistoric, and 6 are of historic age. This rate of positive surveys ( 25 percent) is lower than the results of two of the previous Survey and Impact Evaluation projects done for TxDOT by Prewitt and Associates (42 percent in the Atlanta, Dallas, Fort Worth, Paris, and Waco Districts; 45 percent in the Austin and Waco Districts) and higher than the other (16 percent in the Bryan, Corpus Christi, San Antonio, and Yoakum Districts). The reason for the lower rate of positive surveys in the current project is not apparent, although it does not appear to relate to a decrease in effort expended on surveys. For example, 393 trenches and 293 shovel tests were dug during the 88 surveys reported here, for an average of 4.5 trenches and 3.3 shovel tests per survey. This compares favorably to 5.9 trenches and 1.7 shovel tests per survey in the Austin and Waco Districts; 3.9 trenches and 4.2 shovel tests per survey in the Bryan, Corpus Christi, San Antonio, and Yoakum Districts; and 6.0 trenches and 5.4 shovel tests per survey in the Atlanta, Dallas, Fort Worth, Paris, and Waco Districts. In any case, the rate of positive surveys in the current project is sufficient to 
suggest that conducting surveys in these areas generally was a good idea.

Of the 26 sites investigated during surveys, 6 were recommended for testing to assess eligibility for listing in the National Register of Historic Places and designation as State Archeological Landmarks. All 6 are prehistoric. Site 41WS56 was judged to have the potential for important information because it contains a variety of kinds of cultural materials in a paleosol buried at 90-130 cm within Holocene alluvium. Hence, it is possible that a discrete component may be present and isolable. Site 41BU51 was considered potentially significant because it appeared to have a discrete Archaic component buried at $140-150 \mathrm{~cm}$ in Holocene colluvium. Site $41 B U 75$ was considered to have the potential to contain important information because it contains abundant artifacts in Holocene colluvium that is at least $100 \mathrm{~cm}$ thick, with relatively intact deposits possible below the plowzone. Site 41SV152 was judged potentially significant, in spite of the fact that it is shallowly buried in an upland setting, because it contains features, artifacts, and datable materials and appeared to retain integrity. Site 41HM46 was judged potentially important because buried cultural materials perhaps representing isolable components are present in a paleosol at a depth of 90-175 cm. And 41BL1214 was considered to have the potential for important information because it contains a variety of kinds of cultural materials, including intact features, at $60-220 \mathrm{~cm}$ in Holocene alluvium, with the context suggesting that components could be isolated.

Of the 20 sites (or parts of sites) investigated during surveys and not considered to warrant further work, 6 prehistoric sites (41MA26, 41DW275, 41BU54, 41GM3, 41NL128, and 41SN79) are in upland settings where Holocene sediments are thin or even absent; these have suffered from varying amounts of disturbance, and some have only sparse scatters of artifacts. Because components could not be isolated, these sites lack the capacity to contribute important information. Five sites (41CJ93, 41CJ94, 41BU72, 41HI292, and 41LE325) contain cultural materials buried within Holocene alluvium. Although the contexts of these sites are conducive to the preservation of important information, the archeological remains tend to be so sparse that it is doubtful that interpretable samples representing isolable components could be recovered. Furthermore, some have been disturbed. Similarly, 1 site (41FY420) appears to be buried in Holocene colluvium, but the part in the existing right of way is too disturbed to contain important information. Four sites (41BL1155, 41ML269, 41TV2022, and 41TV2023) are historic-age house sites that are too disturbed or too recent to yield important information. Another historic-age site (41FA69) is a cemetery that lies adjacent to the project area but will not be affected by the proposed Transportation Activity. One site (41GZ210) consists of lithic artifacts found among gravels that had been introduced into the survey area in modern times; because they are redeposited, these artfacts do not convey important information. Finally, no trace of previously recorded sites 41FT529 and 41BL259 was found in two survey areas, leading to recommendations of no further work.

In total, 23 percent of the sites investigated during surveys (30 percent of the prehistoric sites) were considered to have the potential to contain important information. Three of the six potentially important sites (41BU51, 41HM46, and 41BL1214) later were subjected to test excavations by Prewitt and Associates under a separate contract. Of these, one (41BU51), or 33 percent, was found to be eligible for listing in the National Register and designation as a State Archeological Landmark, but the other two were not. It can be argued that the percentages mentioned in this paragraph should be higher, if the point is to maximize the effectiveness of the dollars spent on surveys. That is, shouldn't we be finding higher percentages of significant sites? The answer to this question is not so simple, however. There are many variables that contribute to decisions about when surveys are needed, and all sites encountered during surveys must be recorded, regardless of their apparent significance. There is even a competing argument that the percentages should go down as we get better at discriminating sites that are truly important from ones that are not. Ultimately, simple expectations such as these probably will never, or seldom, be met because the need to make sure that public monies are used effectively must be balanced against the need to ensure that important cultural resources are not lost without receiving the proper treatment. 



\section{REFERENCES CITED}

Antevs, Ernst

1955 Geologic-Climatic Dating in the West. American Antiquity 20:317-335.

Aten, Lawrence E.

1983 Indians of the Upper Texas Coast. Academic Press, New York.

Barber, Byron L.

1969 The Hackberry Site. The Record 25(3):1824.

Barnes, V. E., and P. R. Rose

1981 Geologic Atlas of Texas, Llano Sheet. Bureau of Economic Geology, The University of Texas at Austin.

Bement, Leland C., Wayne Bartholomew, Glenn T. Goode, Stephen A. Hall, and David G. Robinson

1989 Excavations at 41BP19, The Kennedy Bluffs Site, Bastrop County, Texas. Contract Reports in Archaeology, Report Number 5. Texas State Department of Highways and Public Transportation, Highway Design Division, Austin.

Birmingham, W. W., and Thomas Hester

1976 Late Pleistocene Archaeological Remains from the Johnson-Heller Site, Texas Coastal Plain. In Papers on Paleo-Indian Archeology in Texas: 1, pp. 15-33. Special Report No. 3. Center for Archaeological Research, University of Texas at San Antonio.

Black, Stephen L.

1986 The Clemente and Herminia Hinojosa Site, 41JW8: A Toyah Horizon Campsite in Southern Texas. Special Report No. 18. Center for Archaeological Research, The University of Texas at San Antonio. 1989a South Texas Plains. In From the Gulf to the Rio Grande: Human Adaptation in Central, South, and Lower Pecos, Texas, by Thomas R. Hester, Stephen L. Black, D. Gentry Steele, Ben W. Olive, Anne A. Fox, Karl J. Reinhard, and Leland C. Bement, pp. 39-62. Research Series No. 33. Arkansas Archeological Survey, Fayetteville.

1989b Central Texas Plateau Prairie. In From the Gulf to the Rio Grande: Human Adaptation in Central, South, and Lower Pecos, Texas, by Thomas R. Hester, Stephen L. Black, D. Gentry Steele, Ben W. Olive, Anne A. Fox, Karl J. Reinhard, and Leland C. Bement, pp. 17-38. Research Series No. 33. Arkansas Archeological Survey, Fayetteville.

Black, Stephen L., and I Wayne. Cox

1983 A Cultural Resource Survey of Dredge Disposal Sites Along the Gulf Intracoastal Waterway, Brazoria and Matagorda Counties, Texas. Archaeological Survey Report No. 124. Center for Archaeological Research, The University of Texas at San Antonio.

Black, Stephen L., Linda W. Ellis, Darrell G. Creel, and Glenn T. Goode

1997 Hot Rock Cooking on the Greater Edwards Plateau: Four Burned Rock Midden Sites in West Central Texas, Volumes 1 and 2. Studies in Archeology 22. Texas Archeological Research Laboratory, The University of Texas at Austin. Archeology Studies Program, Report 2. Environmental Affairs Department, Texas Department of Transportation, Austin. 
Black, Stephen L., and A. Joachim Mcgraw 1985 The Panther Springs Creek Site: Cultural Change and Continuity within the Upper Salado Creek Watershed, SouthCentral Texas. Archeological Survey Report No. 100. Center for Archaeological Research, The University of Texas at San Antonio.

Bolton, Herbert Eugene

1970 Texas in the Middle Eighteenth Century: Studies in Spanish Colonial History and Administration. The Texas State Historical Association and University of Texas Press, Austin.

Bond, Clell L.

1978 Three Archeological Sites at Hoxie Bridge, Williamson County, Texas. Report No. 43. Anthropology Laboratory, Texas A\&M University, College Station.

Bowman, Bradley F.

1985 Winnie's Mound (41BU17): A Study in the Prehistory of Burleson County, Texas. Bulletin of the Texas Archeological Society 56:39-74.

Boyd, Douglas K.

1995 The Palo Duro Complex: Redefining the Early Ceramic Period in the Caprock Canyonlands. Bulletin of the Texas Archeological Society 66:461-518.

1997 Caprock Canyonlands Archeology: A Synthesis of the Late Prehistory and History of Lake Henry and The Texas PanhandlePlains, Volumes I-II. Report of Investigations No. 110. Prewitt and Associates, Inc., Austin.

2001 Querechos and Teyas: Protohistoric Hunters and Gatherers in the Texas PanhandlePlains, A.D. 1540-1700. Bulletin of the Texas Archeological Society 72:5-22.

Boyd, Douglas K., Martha Doty Freeman, Michael D. Blum, Elton R. Prewitt, and J. Michael Quigg

1989 Phase I Cultural Resources Investigations at Justiceburg Reservoir on the Double Mountain Fork of the Brazos River, Garza and Kent Counties, Texas. Reports of Investigations No. 66. 2 vols. Prewitt and Associates, Inc., Austin.

Brayshaw, Thomas C.

1970 Henrietta Focus of the Possum Kingdom Basin. Unpublished Master's thesis,
Department of Anthropology, The University of Texas at Arlington.

Brooks, Robert L.

1989 Village Farming Societies. In From Clovis to Comanchero: Archeological Overview of the Southern Great Plains, by Jack L. Hoffman, Robert L. Brooks, Joe S. Hays, Douglas W. Owsley, Richard L. Jantz, Murray K. Marks, and Mary H. Manhein, pp. 71-90. Research Series 35. Arkansas Archeological Survey, Fayetteville.

1994 Warfare on the Southern Plains. In Skeletal Biology in the Great Plains: Migration, Warfare, Health, and Subsistence, edited by Douglas W. Owsley and Richard L. Jantz, pp. 317323. Smithsonian Institution Press, Washington, D.C.

Brown, David O.

1983 The Berger Bluff Site (41GD30A): Excavations in the Upper Deposits, 1979. Archaeological Survey Report No. 115. Center for Archaeological Research, The University of Texas at San Antonio.

Brown, David O. (compiler)

1987 Archeology at Aquilla Lake, 1978-1982 Investigations. Research Report 81. Texas Archeological Survey, The University of Texas at Austin.

Brown, David O., and Dana Anthony

1992 Archeological Survey of the Proposed Salt Creek II Substation and Electric Transmission Line, Kent County, Texas. Summary Report 10. Hicks and Company, Inc., Austin.

Brown, Kenneth M.

1996 Berger Bluff. In The New Handbook of Texas, 1:497-498. The Texas State Historical Association, Austin.

Brown, Kenneth M., Daniel R. Potter, Grant D. Hall, and Stephen L. Black

1982 Excavations at 41LK67:A Prehistoric Site in the Choke Canyon Reservoir, South Texas. Choke Canyon series, Volume 7. Center for Archaeological Research, The University of Texas at San Antonio.

Brown, K. L., and S. A. Lebo

1991 Archaeological Testing of the Lewisville Lake Shoreline, Denton County, Texas. Institute of Applied Sciences, University of North Texas, Denton. 
Brown, L. F., Jr., J. L. Goodson, and P. Harwood 1972 Geologic Atlas of Texas, Abilene Sheet. Bureau of Economic Geology, The University of Texas at Austin.

Brown, T. E., J. L. Brewton, J. H. Mcgowen, C. V. Proctor, S. Aronow, And V. E. Barnes

1975 Geologic Atlas of Texas, Beeville-Bay City Sheet. Bureau of Economic Geology, The University of Texas at Austin.

Brown, Theodore M., Kay L. Killen, Helen Simons, and Virginia Wulfkuhle

1982 Resource Protection Planning Process for Texas. Texas Historical Commission, Austin.

Brownlow, Russ

2000 Excavations at Rice's Crossing. Current Archeology in Texas 2(2):4-6. Texas Historical Commission, Austin.

Bruseth, James E., and William A. Martin (editors) 1987 The Bird Point Island and Adams Ranch Sites: Methodological and Theoretical Contributions to North Central Texas Archaeology. Richland Creek Technical Series, Vol. II. Archaeology Research Program, Institute for the Study of Earth and Man, Southern Methodist University, Dallas.

Bruseth, Jim, and Jeff Durst

2002 The Story of the First Presidio La Bahia Slowly Emerges. Current Archeology in Texas, 4(2):1-3. Texas Historical Commission, Austin.

Calhoun, Cecil A.

1999 Majolica and Faience from the Presidio Loreto Site (41VT8). Bulletin of the Texas Archeological Society 70:339354.

Campbell, Thomas N.

1983 Espinosa, Olivares, and the Colorado River Indians, 1709. Sayersville Historical Association Bulletin 3:2-16.

Campbell, T. N.

1947 The Johnson Site: The Type Site of the Aransas Focus of the Texas Coast. Bulletin of the Texas Archeological and Paleontological Society 18:40-75.

1952 The Kent-Crane Site: A Shell Midden on the Texas Coast. Bulletin of the Texas Archeological and Paleontological Society 23:39-77.
1958 Archeology of the Central Southern Sections of the Texas Coast. Bulletin of the Texas Archeological Society 27:746.

1976 Archaeological Investigations at The Morhiss Site, Victoria County, Texas, 1932-1940. In An Archaeological Survey Of Coleto Creek, Victoria and Goliad Counties, Texas, by Anne A. Fox and Thomas R. Hester, pp. 81-85. Archaeological Survey Report No. 18. Center for Archaeological Research, The University of Texas at San Antonio.

1988 Indians of Southern Texas and Northeastern Mexico: Selected Writings of Thomas Nolan Campbell. Texas Archeological Research Laboratory, with the cooperation of the Department of Anthropology, the College of Liberal Arts, and the Institute of Latin American Studies, The University of Texas at Austin.

Campbell, T. N., and T. J. Campbell

1981 Historic Indian Groups of the Choke Canyon Reservoir and Surrounding Area, Southern Texas. Choke Canyon Series, Volume 1. Center for Archaeological Research, The University of Texas at San Antonio.

Carlson, David L., D. Gentry Steele, and A. G. Comuzzie

1984 Mammoth Excavations at the DuewellNewberry Site on the Brazos River in Texas, 1983. Current Research 1:63-64.

Cliff, Maynard B., Richard Martynec, Sharlene N. Allday, and Duane E. Peter

1991 Cultural Resources Sample of the Elm Creek Detention and Channelization Area, Abilene, Taylor County, Texas. Miscellaneous Report of Investigations, No. 21. Geo-Marine, Inc., Plano.

Collins, Michael B.

1968 A Note on Broad Corner-Notched Projectile Points Used in Bison Hunting in Western Texas. The Bull Roarer 3(2):1314. The U. T. Anthropological Society, Department of Anthropology, The University of Texas at Austin.

1990 Observations on Clovis Lithic Technology. Current Research in the Pleistocene 7:7374.

1995 Forty Years of Archeology in Central Texas. 
Bulletin of the Texas Archeological Society 66:361-400.

Collins, Michael B. (assembler and editor) 1998 Wilson-Leonard: An 11,000-year Archeological Record of Hunter-Gatherers in Central Texas, 5 vols. Archeology Studies Program Report 10. Texas Department of Transportation, Environmental Affairs Division, Austin. Studies in Archeology 31. Texas Archeological Research Laboratory, The University of Texas at Austin.

Collins, Michael B., and Kenneth M. Brown

2000 The Gault Gisement: Some Preliminary Observations. Current Archeology in Texas $2(1): 8-11$.

Collins, Michael B., Glen L. Evans, Thomas N. Campbell, Melissa C. Winans, and Charles E. Mear

1989 Clovis Occupation at Kincaid Rockshelter, Texas. Current Research in the Pleistocene $6: 3-4$.

Collins, Michael B., Thomas R. Hester, and Pamela J. Headrick

1992 Engraved Cobbles from the Gault Site, Central Texas. Current Research in the Pleistocene 9:3-4.

Corbin, James E.

1974 A Model for Cultural Succession for the Coastal Bend Area of Texas. Bulletin of the Texas Archeological Society 45:29-54.

1976 The Archaic of the Texas Coast. In The Texas Archaic: A Symposium, edited by Thomas R. Hester, pp. 91-97. Special Report No. 2. Center for Archaeological Research, The University of Texas at San Antonio.

Cox, Kim A., and Herman A. Smith

1988 Kent Crane Revisited. La Tierra 15(3):2428.

Creel, Darrell

1986 A Study of Prehistoric Burned Rock Middens in West Central Texas. Unpublished Ph.D. Dissertation, The University of Arizona, Tucson.

1990

Excavations at 41TG91, Tom Green County, Texas. Publications in Archaeology Report No. 38. Texas State Department of Highways and Public Transportation, Highway Design Division, Austin.
Crook, Wilson W. Jr., and R. K. Harris

1952 Trinity Aspect of the Archaic Horizon: The Carrollton and Elam Foci. Bulletin of the Texas Archeological and Paleontological Society 23:7-38.

1954 Traits of the Trinity Aspect Archaic: Carrollton and Elam Foci. The Record 12(1):2-16.

1957 Hearths and Artifacts of Early Man Near Lewisville, Texas, and Associated Faunal Material. Bulletin of the Texas Archeological Society 28:7-97.

1958 A Pleistocene Campsite Near Lewisville, Texas. American Antiquity 23(3):233-246.

Davis, Michael W., Dan K. Utley, Steve A. Tomka, and Solveig A. Turpin

1987 Continuing Cultural Resource Investigations in the Calvert Prospect: The 1986 Season. Research Report No. 95. Texas Archeological Survey, The University of Texas at Austin.

Davis, Mike, and Jim Bruseth

2000 The Fort St. Louis Archeological Project, October 1999 through Mid-February 2000. Current Archeology in Texas 2(1):1-4.

2001 Recent Archeological and Architectural Discoveries at Fort St. Louis. Current Archeology in Texas, Volume 3, No. 1, pp. 6 7. Texas Historical Commission, Austin.

Davis, Mike, Jeff Durst, Curtis Tunnell, and Jim Bruseth

2000 The Fort St. Louis Archeological Project: An Update on Recent Discoveries. Current Archeology in Texas, Volume 1, No. 2, pp. 1-4. Texas Historical Commission, Austin.

Dawson, Gerald L., and Timothy L. Sullivan 1973 Excavations at Lake Lavon, 1969. Research Report No. 25. Archaeology Research Program, Southern Methodist University, Dallas.

Day, D. William

1984 Archeological Mitigation at the Doyle Martin Site, 41LN178, and the P. I. Ridge Site, 41FT52, Leon and Freestone Counties, Texas. Document No. 82209. Espey, Huston and Associates, Inc., Austin.

Dering, Phil

1999 Earth-Oven Plant Processing in Archaic Period Economies: An Example from a 
Semi-arid Savannah in South-Central North America. American Antiquity 64(4):659-674.

Denton, Joe T.

1983 Test Excavations at Site 41KT32, Kent County, Texas. Texas Department of Highways and Public Transportation, Austin.

Diamond, David D., David H. Riskind, and Steve L. Orzell

1987 A Framework for Plant Communities Classification and Conservation in Texas. Texas Journal of Science 39(3):203221.

Dibble, David S., and Dessamae Lorrain

1968 Bonfire Shelter: A Stratified Bison Kill Site, Val Verde County, Texas. Miscellaneous Papers No. 1. Texas Memorial Museum, The University of Texas At Austin.

Dillehay, Tom D.

1974 Late Quaternary Bison Population Changes on the Southern Plains. Plains Anthropologist 19(64):180-196.

Duffield, Lathel F.

1963 The Strawn Creek Site: A Mixed Archaic and Neo-American Site at Navarro Mills Reservoir, Navarro County, Texas. Report Submitted to the National Park Service by the Texas Archeological Salvage Project, The University of Texas at Austin.

Eifler, G. K., Jr., J. C. Frye, and A. B. Leonard 1967 Geologic Atlas of Texas, Lubbock Sheet. Bureau of Economic Geology, The University of Texas at Austin.

1974 Geologic Atlas of Texas, Big Spring Sheet. Bureau of Economic Geology, The University of Texas at Austin.

Ensor, H. Blaine, and Catherine S. Mueller-Wille 1988 Excavations at the Bull Pen Site, 41BP280, Colorado River Drainage, Bastrop County, Texas. Contract Reports in Archaeology, Report Number 3. Texas State Department of Highways and Public Transportation, Highway Design Division, Austin.

Ensor, H. Blaine, Joe W. Saunders, and C. S. MuellerWille

1992 Prehistoric Synthesis. In An Archeological Survey of the Proposed South Bend Reservoir Area: Young, Stephens, and
Throckmorton Counties, Texas, edited by Joe W. Saunders, C. S. Mueller-Wille, and David L. Carlson, pp. 259-303. Archeological Surveys No. 6. Archeological Research Laboratory, Texas A\&M University, College Station.

Etchieson, Gerald Meeks, Roberta D. Speer, and Jack T. Hughes

1979 Archeological Investigations in the Crowell Reservoir Area, King and Knox Counties, Texas. Archeological Research Laboratory, Killgore Research Center, West Texas State University, Canyon.

Fenneman, Nevin M.

1931 Physiography of Western United States. McGraw-Hill Book Company, Inc., New York.

1938 Physiography of Eastern United States. McGraw-Hill Book Company, Inc., New York.

Ferring, C. Reid

1975 An Archeological Survey of the Grapevine Dam Area, Tarrant County, Texas. Archeology Research Program, Southern Methodist University, Dallas.

2001 The Archaeology and Paleoecology of the Aubrey Clovis Site (41DN479), Denton County, Texas. Center for Environmental Archaeology, Department of Geography, University of North Texas, Denton.

Ferring, C. Reid, and Bonnie C. Yates

1997 Holocene Geoarcheology and Prehistory of the Ray Roberts Lake Area. Institute of Applied Sciences, University of North Texas, Denton.

1998 Archaeological Investigations at Five Prehistoric Sites at Lewisville Lake, Denton County, Texas. Center for Environmental Archaeology, University of North Texas, Denton.

Fields, Ross C.

1995 The Archeology of the Post Oak Savannah of East Central Texas. Bulletin of the Texas Archeological Society 66:301-330.

Fields, Ross C. (editor)

1987 Excavations at the Alley Road Site (41ln30), Jewett Mine Project, Leon County, Texas. Reports of Investigations No. 61. Prewitt and Associates, Inc., Austin. 
1990 Excavations at the Charles Cox, Lambs Creek Knoll, and Buffalo Branch Sites, Jewett Mine Project, Leon and Freestone Counties, Texas. Reports of Investigations No. 70. Prewitt and Associates, Inc., Austin.

Fields, Ross C., and L. Wayne Klement

1995 Excavations at the Cottonwood Springs Site, Jewett Mine Project, Leon County, Texas. Reports of Investigations No. 102. Prewitt and Associates, Inc., Austin.

Fields, Ross C., Jennifer K. McWilliams, Corey J. Broehm, and Karl W. Kibler

2004 Interim Report on Test Excavations At 41BU51, Burleson County, Texas. Interim Report submitted to the Texas Department of Transportation, Environmental Affairs Division, by Prewitt and Associates, Inc., Austin.

Fields, Ross C., L. Wayne Klement, C. Britt Bousman, Steve A. Tomka, Eloise F. Gadus, and Margaret A. Howard

1991 Excavations at the Bottoms, Rena Branch, and Moccasin Springs Sites, Jewett Mine Project, Freestone and Leon Counties, Texas. Reports of Investigations No. 82. Prewitt and Associates, Inc., Austin.

Forrester, R. E.

1994 Two Henrietta Focus Sites on the Brazos River in North Central Texas. Bulletin of the Texas Archeological Society 62:249266.

Foster, William C.

1995 Spanish Expeditions into Texas 16891768. University of Texas Press, Austin.

Fox, Anne A., and Thomas R. Hester

1976 Archaeological Survey of Coleto Creek, Victoria and Goliad Counties, Texas. Archaeological Survey Report No. 18. Center for Archaeological Research, The University of Texas at San Antonio.

Fox, Anne A., S. L. Black, and S. James

1979 Intensive Survey and Testing of Archaeological Sites on Coleto Creek, Victoria and Goliad Counties, Texas. Archaeological Survey Report No. 67. Center for Archaeological Research, The University of Texas at San Antonio.

Frederick, Charles, D., and Christopher Ringstaff 1994 Lithic Resources at Fort Hood: Further Investigation. In Archeological Investiga- tions on 571 Prehistoric Sites at Fort Hood, Bell and Coryell Counties, Texas, Management Series, Research Report No. 31. United States Army, Fort Hood.

Fritz, Gayle

1975 Matagorda Bay Area, Texas: A Survey of the Archeological and Historical Resources. Research Report No. 45. Texas Archeological Survey, The University of Texas at Austin.

Fullem, Bruce B.

1977 The Black Hopper Site. Report No. 10. State Department of Highways and Public Transportation, Highway Design Division, Austin.

Gadus, Eloise F., Ross C. Fields, and Jennifer K. McWilliams

2003 Interim Report on Data Recovery Excavations at 41MM341, Milam County, Texas. Interim Report submitted to the Texas Department of Transportation, Environmental Affairs Division, by Prewitt and Associates, Inc., Austin.

Gadus, E. Frances, Jennifer K. McWilliams, and Ross C. Fields

2002 Data Recovery Excavations at the McGuire's Garden Site (41FT425), Jewett Mine, Freestone County, Texas. Reports of Investigations No. 134. Prewitt and Associates, Inc., Austin.

Gill-King, H.

1987 The Human Osteology of 41CO141. In Test Excavations at 41CO141, Ray Roberts Reservoir, Cooke County, Texas, edited by Daniel J. Prikryl and Bonnie C. Yates, pp. 101-104. Contributions in Archaeology No. 4. Institute of Applied Sciences, North Texas State University, Denton.

Gilmore, Kathleen Kirk

1996a San Francisco Xavier de Horcasitas Mission. In The New Handbook of Texas, 5:849. The Texas State Historical Association, Austin.

1996b San Ildefonso Mission. In The New Handbook of Texas, 5:853-854. The Texas State Historical Association, Austin.

Goode, Glenn T.

1991 Late Prehistoric Burned Rock Middens in Central Texas. In The Burned Rock Middens of Texas: An Archeological Symposium, edited by Thomas R. Hester, 
pp. 71-93. Studies in Archeology 13. Texas Archeological Research Laboratory, The University of Texas at Austin.

Goode, Glenn T., and Robert J. Mallouf

1991 The Evant Cores: Polyhedral Blade Cores from North-Central Texas. Current Research in the Pleistocene 8:67-70.

Green, F. E.

1963 The Clovis Blades: An Important Addition to the Llano Complex. American Antiquity 29(2):145-165.

Green, L. M., and Thomas R. Hester

1973 The Finis Frost Site: A Toyah Phase Occupation In San Saba County, Central Texas. Bulletin of the Texas Archeological Society 44:69-88.

Hall, Grant D.

1981 Allens Creek: A Study in the Cultural Prehistory of the Brazos River Valley, Texas. Research Report No. 61. Texas Archeological Survey, The University of Texas at Austin.

1995a A Perspective on Some Prehistoric Cemeteries in Texas: Loma Sandia in the Regional Setting. In Archeological Investigations at the Loma Sandia Site (41LK28). A Prehistoric Cemetery and Campsite in Live Oak County, Texas, by Anna Jean Taylor and Cheryl Lynn Highley, 1:47-56. Studies in Archeology 20. Texas Archeological Research Laboratory, The University of Texas at Austin.

1995b Prehistoric Cemeteries on the Texas Central Coastal Plain: Interpretations and Hypotheses. In Archeological Investigations at the Loma Sandia Site (41LK28). A Prehistoric Cemetery and Campsite in Live Oak County, Texas, by Anna Jean Taylor and Cheryl Lynn Highley, 2:633-647. Studies in Archeology 20. Texas Archeological Research Laboratory, The University of Texas at Austin.

Hall, Grant D., Stephen L. Black, and Carol Graves

1982 Archaeological Investigations at Choke Canyon Reservoir, South Texas: The Phase I Findings. Choke Canyon Series Volume 5. Center for Archaeological Research, The University of Texas at San Antonio.
Hall, Grant D., Thomas R. Hester, and Stephen L. Black

1986 The Prehistoric Sites at Choke Canyon Reservoir, South Texas: Results of Phase II Archaeological Investigations. Choke Canyon Series: Volume 10. Center for Archaeological Research, The University of Texas at San Antonio.

Harris, R. K.

1945 Bone Implement Burial, Collin County, Texas. Bulletin of the Texas Archeological and Paleontological Society 16:84-89.

Harris, R. K., and Inus Marie Harris

1970 A Bison Kill on Dixon's Branch, Site 27A25, Dallas County, Texas. The Record 27(1):1-4.

Harris, R. K., and Dee Ann Suhm (editors)

1963 An Appraisal of the Archeological Resources of Forney Reservoir, Collin, Dallas, Kaufman, and Rockwall Counties, Texas. Texas Archeological Salvage Project, The University of Texas at Austin.

Hatfield, Virginia L.

1997 Paleoindian Evidence at the Triple S Ranch Site, Hamilton County, Texas. Current Research in the Pleistocene 14:32-34.

Hays, T. R. (compiler and editor)

1982 Archaeological Investigations at the San Gabriel Reservoir Districts, Central Texas. Archaeology Program, Institute of Applied Sciences, North Texas State University, Denton.

Hayward, O. T.

1988a The Comanchean Section of the Trinity Shelf, Central Texas. In South-Central Section of the Geological Society of America, Centennial Field Guide Volume 4, edited by O. T. Hayward, pp. 323-328. Geological Society of America, Boulder, Colorado.

1988b Gulfian Rocks, Western Margin of the East Texas Basin. In South-Central Section of the Geological Society of America, Centennial Field Guide Volume 4, edited by O. T. Hayward, pp. 329-334. Geological Society of America, Boulder, Colorado.

Hayward, O. T., Peter M. Allen, and David L. Amsbury 1996 Lampasas Cut Plain: Episodic Development of An Ancient and Complex Regional Landscape, Central Texas. In Guidebook 
to Upland, Lowland, and In BetweenLandscapes in the Lampasas Cut Plain, edited by David L. Carlson, pp. 1-1 through 1-97. Friends of the Pleistocene SouthCentral Cell 1996 Field Trip. Department of Anthropology, Texas A\&M University, College Station, and Department of Geology, Baylor University, Waco.

Hentz, T. F., and L. F. Brown Jr.

1987 Geologic Atlas of Texas, Wichita FallsLawton Sheet. Bureau of Economic Geology, The University of Texas at Austin.

Hester, Thomas R.

1976 Late Pleistocene Aboriginal Adaptations in Texas. In Papers on Paleo-Indian Archaeology in Texas: I, pp. 1-10. Special Report No. 3. Center for Archaeological Research. The University of Texas at San Antonio.

1980 A Survey of Paleo-Indian Remains Along the Texas Coast. In Papers on the Archaeology of the Texas Coast, edited by L. Highley and T. R. Hester, pp. 1-22. Special Report 11. Center for Archaeological Research, The University of Texas at San Antonio.

1995 The Prehistory of South Texas. Bulletin of the Texas Archeological Society 66:427459 .

1999 Artifacts, Archeology, and Cabeza de Vaca in Southern Texas and Northeastern Mexico. Bulletin of the Texas Archeological Society 70:17-28.

Hester, Thomas R., and Michael B. Collins

1969 Burials from the Frisch Auf! Site: 41FY2. Texas Journal of Science 20(3):261-272.

Harrison, Billy R., and Kay L. Killen

1978 Lake Theo: A Stratified Early Man Bison Butchering and Camp Site, Briscoe County, Texas: Archeological Investigations, Phase II. Panhandle-Plains Historical Museum, Special Archeological Report No. 1. West Texas State University, Canyon.

Hickerson, Nancy P.

1994 The Jumanos, Hunters and Traders of the Southern Plains. University of Texas Press, Austin.

Highley, Cheryl Lynn

1986 Archaeological Investigations at 41LK201,
Choke Canyon Reservoir, Southern Texas. Choke Canyon series, Volume 11. Center for Archaeological Research, The University of Texas at San Antonio.

Hindes, Kay V., Anne E. Fox, and E. H. Schmiedlin 1999 An Overview of Test Excavations and Documentary Research at 41VT10, the Tonkawa Bank Site, Victoria City Park, Victoria Texas. Bulletin of the Texas Archeological Society 70:79-96.

Hoffman, Jack L.

1989 Prehistoric Culture History: Hunters and Gatherers in the Southern Great Plains. In From Clovis to Comanchero: Archeological Overview of the Southern Great Plains. Hoffman, Jack L., Robert L. Brooks, Joe S. Hays, Douglas W. Owsley, Richard L. Jantz, Murray K. Marks, and Mary H. Manhein Research Series No. 35. Arkansas Archeological Survey, Fayetteville.

Hoffman, Jack L., Robert L. Brooks, Joe S. Hays, Douglas W. Owsley, Richard L. Jantz, Murray K. Marks, and Mary H. Manhein

1989 From Clovis to Comanchero: Archeological Overview of the Southern Great Plains. Research Series No. 35. Arkansas Archeological Survey, Fayetteville.

Holden, W. C.

1929 Some Recent Explorations and Excavations in Northwest Texas. Bulletin of the Texas Archeological and Paleontological Society 1:23-35.

Holliday, Vance T.

1997 Paleoindian Geoarchaeology of the Southern High Plains. University of Texas Press, Austin.

Huebner, Jeffery A.

1988 The Archaeology of Blue Bayou: A Late Prehistoric and Archaic Mortuary Site, Victoria County, Texas. M.A. thesis, Department of Anthropology, The University of Texas at San Antonio.

1991 Late Prehistoric Bison Populations in Central and South Texas. Plains Anthropologist 36(137):343-358.

Hughes, Jack T.

1942 An Archeological Excavation on the Harrell Site of North Central Texas. Unpublished Master's thesis, Department of Anthropology, The University of Texas at Austin. 
1991 Prehistoric Cultural Developments on the Texas High Plains. Bulletin of the Texas Archeological Society 60:1-55.

Jelks, Edward B.

1952 Appraisal of the Archeological and Paleontological Resources of the Colorado City Reservoir, Borden and Scurry Counties, Texas. River Basin Surveys, Smithsonian Institution, Washington, D.C.

1962 The Kyle Site: A Stratified Central Texas Aspect Site in Hill County, Texas. Archaeology Series No. 5. Department of Anthropology, The University of Texas at Austin.

1970 Documentary Evidence of Indian Occupation at the Stansbury Site (41-39b1-1), Appendix B. Bulletin of the Texas Archeological Society 41:277-286.

Johnson, Eileen (editor)

1977 Paleoindian Lifeways. The Museum Journal XVII. West Texas Museum Association, Texas Tech University, Lubbock.

Johnson, LeRoy, Jr.

1991 Early Archaic Life at the Sleeper Archaeological Site, 41BC65, of the Texas Hill Country, Blanco County, Texas. Publications in Archaeology, Report 39. Texas Department of Highways and Public Transportation, Highway Design Division, Austin.

1994 The Life and Times of Toyah-Culture Folk As Seen from the Buckhollow Encampment, Site 31KM16, of Kimble County, Texas. Office of the State Archeologist Report 38. Texas Department of Transportation and Texas Historical Commission, Austin.

1995 Past Cultures and Climates at Jonas Terrace: 41ME29 of Medina County, Texas. Report No. 40. Office of the State Archeologist, Texas Historical Commission, Austin.

2000 Life and Death as Seen at the Bessie Kruze Site (41WM13) on the Blackland Prairie of Williamson County, Texas. Archeology Studies Program, Report 22. Environmental Affairs Division, Texas Department of Transportation, Austin.

Johnson, LeRoy, and Glenn T. Goode

1994 A New Try at Dating and Characterizing
Holocene Climates, as Well as Archeological Periods, on the Eastern Edwards Plateau. Bulletin of the Texas Archeological Society 65:1-51.

Johnson, LeRoy, Jr., Dee Ann Suhm, and Curtis D. Tunnell

1962 Salvage Archeology of Canyon Reservoir: The Wunderlich, Footbridge, and Oblate Sites. Bulletin No. 5. Texas Memorial Museum, The University of Texas at Austin.

Karbula, James W., Rachel Feit, and Timothy B. Griffith

2001 Changing Perspectives on the Toyah: Data Recovery Investigations of 41tv441, The Toyah Bluff Site, Travis County, Texas. Archeology Series No. 94. Hicks and Company, Austin.

Katz, Paul, and Susana R. Katz

2001 Data Recovery at the Bear Branch Site (41CA13), Callahan County, Texas. PRIAM, Panhandle, Texas.

Kelley, J. Charles

1947a The Cultural Affiliations and Chronological Position of the Clear Fork Focus. American Antiquity 13(2):97-109.

1947b The Lehmann Rock Shelter: A Stratified Site of the Toyah, Uvalde, and Round Rock Foci. Bulletin of the Texas Archeological Society 18:115-128.

Kelley, J. C., and T. N. Campbell

1942 What are the Burnt Mounds of Texas? American Antiquity 7(3):319-322.

Kenmotsu, Nancy Adele

2001 Seeking Friends, Avoiding Enemies: the Jumano Response to Spanish Colonization, A.D. 1580-1750. Bulletin of the Texas Archeological Society 72:23-43.

Kerr, Anne C., and Susan W. Dial

1998 Statistical Analysis of Unfluted Lanceolate and Early Bifurcate Stem Projectile Points. In Wilson-Leonard: An 11,000-Year Archeological Record of Hunter-Gatherers in Central Texas, Volume II, edited and assembled by Michael B. Collins, pp. 447-505. Studies in Archeology 31. Texas Archeological Research Laboratory, The University of Texas at Austin. Archeology Studies Program, Report 10. Environmental Affairs Division, Texas Department of Transportation. 
Kibler, Karl W., and Ann M. Scott

2000 Archaic Hunters and Gatherers of the Balcones Canyonlands: Data Recovery Excavations at the Cibolo Crossing Site (41BX377), Camp Bullis Military Reservation, Bexar County, Texas. Reports of Investigations No. 126. Prewitt and Associates, Inc., Austin.

Kier, R. S., L. F. Brown Jr., and P. Harwood

1976 Geologic Atlas of Texas, Brownwood Sheet. Bureau of Economic Geology, The University of Texas at Austin.

Kleinbach, Karl, Gemma Mehalchick, Douglas K. Boyd, and Karl W. Kibler

1999 National Register Testing of 42 Prehistoric Archeological Sites on Fort Hood, Texas: The 1996 Season. Research Report No. 38. Archeological Resource Management Series, United States Army, Fort Hood.

Kleinbach, Karl, Gemma Mehalchick, James T. Abbott, and J. Michael Quigg

1995 Other Analyses. In NRHP Significance Testing of 57 Prehistoric Archeological Sites on Fort Hood, Texas, Volume III, edited by James T. Abbott and W. Nicholas Trierweiler, pp. 765-842. Archeological Resource Management Series, Research Report No. 34. United States Army, Fort Hood.

Kotter, Steven M., Patience E. Patterson, Dan K. Utley, and Henry B. Moncure

1991 Final Report Of Cultural Resource Investigations At The Cummins Creek Mine, Fayette County, Texas. Studies In Archeology 11. Texas Archeological Research Laboratory, The University Of Texas at Austin.

Krieger, Alex D.

1946 Culture Complexes and Chronology in Northern Texas with Extension of Puebloan Dating to the Mississippi Valley. University of Texas Publication No. 4640. Austin.

Krieger, Margery $\mathrm{H}$.

1996 Tawakoni Indians. In The New Handbook of Texas, 6:213, edited by Ron Tyler. The Texas State Historical Association, Austin.

LBJ School of Public Affairs

1978 Preserving Texas' Natural Heritage. Project Report 31. Natural Heritage Policy
Research Project, The University of Texas at Austin.

Leffler, John

1996a Brown County. In The New Handbook of Texas, 1:769-771, edited by Ron Tyler. The Texas State Historical Association, Austin.

1996b Eastland County. In The New Handbook of Texas, 2:765-766, edited by Ron Tyler. The Texas State Historical Association, Austin.

Lintz, Christopher, Abby C. Treece, Fred Oglesby, Karl Kibler, Patrick L. O'Neill, W. Nicholas Trierweiler, Charles Frederick, J. Michael Quigg, and A. J. Taylor

1993 Cultural Resource Investigations in the O.H. Ivie Reservoir, Concho, Coleman, and Runnels Counties, Texas, Volume II: Test Excavations at Prehistoric Sites and Assessment of Rock Cairn Features. Technical Report No. 346-II. Mariah Associates, Inc., Austin.

Lintz, Christopher, W. Nicholas Trierweiler, Fred Oglesby, Patrick O'Neill, William Doering, and Michael McFaul

1991 A Cultural Resource Survey at Mitchell Reservoir, Mitchell County, Texas. Technical Report 433. Mariah Associates, Inc., Austin.

Lorrain, Dessamae

1967 The Glass Site. In A Pilot Study of Wichita Indian Archeology and Ethnohistory, edited by Robert E. Bell, Edward B. Jelks, and W. W. Newcomb, pp. 24-44. Final Report for National Science Foundation Grant GS-964.

1969 Archeological Excavations in the Fish Creek Reservoir. Contributions in Anthropology No. 4. Department of Anthropology, Southern Methodist University, Dallas.

Lorrain, Dessamae, and Norma Hoffrichter 1968 The Lower Rockwall Site, Rockwall County, Texas. Archaeological Salvage Project, Southern Methodist University, Dallas.

Lynott, Mark J.

1975 Archaeological Excavations at Lake Lavon, 1974. Contributions in Anthropology No. 16. Department of Anthropology, Southern Methodist University, Dallas. 
1977 A Regional Model for Archaeological Research in North Central Texas. Unpublished Ph.D. dissertation, Southern Methodist University, Dallas.

1979

Survey and Testing in the Elm Creek Watershed, Upper Colorado River Drainage, Texas (Floodwater Retarding Structures 1-10). Research Report 106. Archeological Research Program, Southern Methodist University, Dallas.

1981 A Model of Prehistoric Adaptation in Northern Texas. Plains Anthropologist 26(92):97-110.

Mack, Steven R.

1994 Archaeological Investigations at the Van York Site (41BD8): A Late Archaic Lithic Scatter in the Western Rolling Plains of Texas. Unpublished Master's thesis, Department of Anthropology, University of Tulsa.

Mahoney, Richard B., Steve A. Tomka, Raymond P. Mauldin, Harry J. Shafer, Lee C. Nordt, Russell D. Greaves, and Rebecca R. Galdeano

2003 Data Recovery Excavations at 41MM340: A Late Archaic Site along Little River in Milam County, Texas. Archeological Studies Program Report No. 54. Environmental Affairs Division, Texas Department of Transportation, Austin. Archaeological Survey Report No. 340. Center for Archaeological Research, The University of Texas at San Antonio.

Mallouf, Michael G.

1979 Archeological Investigations at Lake Limestone. Research Report No. 71. Texas Archeological Survey, The University of Texas at Austin.

Mallouf, Robert J.

1981 A Case Study of Plow Damage to Chert Artifacts: The Brookeen Creek Cache, Hill County, Texas. Office of the State Archeologist Report 33. Texas Historical Commission, Austin.

1989 A Clovis Quarry Workshop in the Callahan Divide: The Yellow Hawk Site. Plains Anthropologist 34(124):81-103.

Mallouf, Robert J., Daniel E. Fox, and Alton Briggs 1973 An Assessment of the Cultural Resources of Palmetto Bend Reservoir, Jackson County, Texas. Archeological Survey Re- port Number 11. Texas Historical Commission and Texas Water Development Board.

Martin, Ernest R.

1994 The Dillard Site, a Late Prehistoric Village on the Red River in Cooke County, Texas. Bulletin of the Texas Archeological Society 62:105-200.

Mauldin, Raymond P., and David L. Nickels

2003 Burned Rock Middens in Texas. Chapter 11 in: Archaeological Testing to Determine the National Register Eligibility Status of 18 Prehistoric Sites on Camp Bowie, Brown County, Texas, by Raymond P. Mauldin, David L. Nickels, and Cory J. Broehm. pp. 217-231. Archaeological Survey Report No. 334, Center for Archaeological Research, The University of Texas at San Antonio.

McGowen, J. H., D. E. Owen, M. K. Pieper, and C. A. Shelby

1967 Geologic Atlas of Texas, Sherman Sheet. Bureau of Economic Geology, The University of Texas at Austin.

McGowen, J. H., C. V. Proctor, W. T. Haenggi, D. F. Reaser, and V. E. Barnes

1972 Geologic Atlas of Texas, Dallas Sheet. Bureau of Economic Geology, The University of Texas at Austin.

McGregor, Daniel E., and James E. Bruseth (editors) 1987 Hunter-Gatherer Adaptations Along the Prairie Margin: Site Excavations and Synthesis of Prehistoric Archaeology. Richland Creek Technical Series, Vol. III. Archaeology Research Program, Institute for the Study of Earth and Man, Southern Methodist University, Dallas.

McGraw, A. Joachim, John W. Clark Jr., and Elizabeth A. Robbins

1991 A Texas Legacy, The Old San Antonio Road and the Caminos Reales, A Tricentennial History, 1691-1991. Texas Department of Transportation, Environmental Affairs Department, Austin.

McGregor, Daniel E., and James E. Bruseth (editors) 1987 Hunter-Gatherer Adaptations Along the Prairie Margin: Site Excavations and Synthesis of Prehistoric Archaeology. Richland Creek Technical Series, Vol. III. Archaeology Research Program, Institute for the Study of Earth and Man, Southern Methodist University, Dallas. 
McKinney, Wilson W.

1981 Early Holocene Adaptations in Central and Southwestern Texas: The Problem of the Paleoindian-Archaic Transition. Bulletin of the Texas Archeology Society 52:91120.

Mehalchick, Gemma, Karl Kleinbach, Douglas K. Boyd, And Karl W. Kibler

2000 Geoarcheological Investigations and $\mathrm{Na}$ tional Register Testing of 52 Prehistoric Archeological Sites on Fort Hood, Texas: The 1997 Season. Research Report No. 39. Archeological Resource Management Series, United States Army, Fort Hood.

Mehalchick, Gemma, Karl Kleinbach, Douglas K. Boyd, Steve A. Tomka, and Karl W. Kibler

1999 National Register Testing of 19 Prehistoric Archeological Sites at Fort Hood, Texas: The 1995 Season. Research Report No. 37. Archeological Resource Management Series, United States Army, Fort Hood.

Meltzer, David J.

1986 The Clovis Paleoindian Occupation of Texas: Results of the Texas Fluted Point Survey. Bulletin of the Texas Archeological Society 57:27-68.

Meltzer, David J., and Michael R. Bever

1995 Paleoindians of Texas: An Update on the Texas Clovis Fluted Point Survey. Bulletin of the Texas Archeological Society $66: 47-81$.

Moore, William E.

2001 A Phase I Archaeological Survey along a 7.2 Mile Segment of State Highway 21/ US 190 Between North Zulch and Madisonville in Central Madison County, Texas. Contract Report No. 70. Brazos Valley Research Associates, Bryan, Texas.

Morgan, Larry W.

1975 An Empirical Analysis of a pre-NeoAmerican Site in Dallas County, Texas. Unpublished Master's thesis, The University of Texas at Arlington.

Morris, Virginia, and Bill Morris

1970 Excavation of Bison Remains in Northwest Dallas County. The Record 27(1):25 .

Newcomb, W. W. Jr.

1961 The Indians of Texas: From Prehistoric to Modern Times. University of Texas Press, Austin.
1993 Historic Indians of Central Texas. Bulletin of the Texas Archeological Society 64:163.

Newcomb, W. W., and T. N. Campbell

1982 Southern Plains Ethnohistory:A Reexamination of the Escanjaques, Ahijados, and Cuitoas. In Pathways to Plains Prehistory: Anthropological Perspectives of Plains Natives and Their Pasts, edited by Don G. Wyckoff and Jack L. Hoffman, pp. 29-43. Oklahoma Anthropological Society Memoir 3 and The Cross Timbers Heritage Association Contributions 1, Duncan, Oklahoma.

Odintz, Mark

1996 Elmdale. In The New Handbook of Texas, Vol. 2:840. The Texas State Historical Association, Austin.

Peter, Duane E., and Daniel E. McGregor (editors)

1988 Late Holocene Prehistory of the Mountain Creek Drainage. Joe Pool Lake Archaeological Project, Vol. I. Archaeology Research Program, Southern Methodist University, Dallas.

Peterson, Fredrick A.

1965 The Erwin's Bridge Site at Somerville Reservoir, Burleson County, Texas. Texas Archeological Salvage Project, The University of Texas at Austin.

Preston, Nolan E.

1969 The McCann Site. Bulletin of the Texas Archeological Society 40:167-192.

Prewitt, Elton R.

1974 Archeological Investigations at the LoeveFox Site, Williamson County, Texas. Research Report 49. Texas Archeological Survey, The University of Texas at Austin.

1981 Cultural Chronology in Central Texas. Bulletin of the Texas Archeological Society 52:65-89.

1982 Archeological Investigations at the LoeveFox Site, Williamson County, Texas. Reprints in Archeology No. 1. Prewitt and Associates, Inc., Austin.

1985 From Circleville to Toyah: Comments on Central Texas Chronology. Bulletin of the Texas Archeological Society 54:201-238.

1995 Distributions of Typed Projectile Points in 
Texas. Bulletin of the Texas Archeological Society 66:83-173.

Prewitt, Elton R., Susan V. Lisk, and Margaret A. Howard

1987 National Register Assessments of the Swan Lake Site, 41AS16, on Copano Bay, Aransas County, Texas. Reports of Investigations No. 56. Prewitt and Associates, Inc., Austin.

Prikryl, Daniel

1990 Lower Elm Fork Prehistory: A Redefinition of Cultural Concepts and Chronologies along the Trinity River, North-Central Texas. Office of the State Archeologist Report 37. Texas Historical Commission, Austin.

1993 Regional Preservation Plan for Archeological Resources, Prairie-Savanna Archeological Region: Introduction. In Archeology in the Eastern Planning Region, Texas: A Planning Document, edited by Nancy Adele Kenmotsu and Timothy K. Perttula, pp. 191-204. Cultural Resource Management Report 3. Department of Antiquities Protection, Texas Historical Commission, Austin.

Prikryl, Daniel J., and Bonnie C. Yates

1987 Test Excavations at 41CO141, Ray Roberts Reservoir, Cooke County, Texas. Contributions in Archaeology No. 4. Institute of Applied Sciences, North Texas State University, Denton.

Proctor, C. V., Jr., T. E. Brown, J. H. Mcgowen, and N. B. Waechter

1981 Geologic Atlas of Texas, Austin Sheet. Bureau of Economic Geology, The University of Texas at Austin.

Proctor, C. V., Jr., T. E. Brown, N. B. Waechter, S. Aronow, M. K. Pieper, and V. E. Barnes

1979 Geologic Atlas of Texas, Seguin Sheet. Bureau of Economic Geology, The University of Texas at Austin.

Proctor, C. V., Jr., J. H. McGowen, and W. T. Haenggi 1970 Geologic Atlas of Texas, Waco Sheet. Bureau of Economic Geology, The University of Texas at Austin.

Ray, Cyrus N.

1929 A Differentiation of the Prehistoric Cultures of the Abilene Region. Bulletin of the Texas Archeological and Paleontological Society 1:7-22.
1930 Report on Some Research in the Abilene Section. Bulletin of the Texas Archeological and Paleontological Society 2:4558.

1934 Flint Cultures of Ancient Man in Texas. Bulletin of the Texas Archeological and Paleontological Society. 5:14-24.

1936 Some Unusual Cremated Burials Found near Colorado, Texas. Bulletin of the Texas Archeological and Paleontological Society 8:9-16.

1938 The Clear Fork Culture Complex. Bulletin of the Texas Archeological and Paleontological Society 10:193-207.

1940 The Deeply Buried Gibson Site. Bulletin of the Texas Archeological and Paleontological Society. 12:223-237.

1945 Stream Bank Silts of the Abilene Region. Bulletin of the Texas Archeological and Paleontological Society 16:117-147.

Ray, Cyrus N., and Kirk Bryan

1938 Folsomoid Point Found in Alluvium Beside Mammoth's Bones. Science 88(2281):257258 .

Ray, Cyrus N., and E. B. Sayles

1941 An Agreement on Abilene Region Terminology. Bulletin of the Texas Archeological and Paleontological Society. 13:175-176.

Redder, Albert J.

1985 Horn Shelter Number 2: The South End, A Preliminary Report. Central Texas Archeologist 10:37-65.

Ricklis, Robert A.

1988 Archeological Investigations at the McKinzie Site (41NU221) Nueces County, Texas: Description and Contextual Interpretations. Bulletin of the Texas Archeological Society 58:1-76.

1989 Historical Cultural Ecology of the Karankawan Indians of the Central Texas Coast: A Case Study in the Roots of Adaptive Change. Ph.D. dissertation, Department of Geography, The University of Texas at Austin.

1995 Prehistoric Occupation of the Central and Lower Texas Coast: A Regional Overview. Bulletin of the Texas Archeological Society 66:265-300. 
1996 The Karankawa Indians of Texas. An Ecological Study of Cultural Tradition and Change. University of Texas Press, Austin.

1999 The Spanish Colonial Missions of Espiritu Santo (41GD1) and Nuestra Señora del Rosario (41GD2), Goliad, Texas: Exploring Patterns of Ethnicity, Interaction, and Acculturation. Bulletin of the Texas Archeological Society 70:132-168.

2001 National Register Eligibility Testing at 41LE177, Alcoa Sandow Mine, Lee County, Texas: Archaeological, Geoarchaeological, and Paleoenvironmental Assessment of an Upland Sandy Mantle Site. Coastal Archaeological Research, Inc., Corpus Christi.

Ricklis, Robert A., and Michael B. Collins

1994 Archaic and Late Prehistoric Human Ecology in the Middle Onion Creek Valley, Hays County, Texas. Studies in Archeology 19. Texas Archeological Research Laboratory, The University of Texas at Austin.

Robinson, David G., and Solveig A. Turpin

1993 Hunter-Gatherer Mobility and Settlement in the Brazos Uplands: Archeology in the Calvert Mine, Robertson County, EastCentral Texas. Studies in Archeology 14. Texas Archeological Research Laboratory, The University of Texas at Austin.

Roemer, Erwin, Jr., and Shawn Bonath Carlson

1987 Excavations at 41BU16: State Highway 21 at the Brazos River, Burleson County, Texas. Contract Reports in Archaeology, Report Number 1. Texas State Department of Highways and Public Transportation, Highway Design Division, Austin.

Rogers, Robert

1993 Data Recovery of Three Prehistoric Sites at the Gibbons Creek Third Five-Year Mine Permit Area, Grimes County, Texas. Document No. 910529. Espey, Huston and Associates, Inc., Austin.

1994 Excavations at Site 41GM224 in Gibbons Creek Lignite Mine Permit 38A Area, Grimes County, Texas. Document No. 930476. Espey, Huston and Associates, Inc., Austin.

1995 Excavations at Sites 41GM166, 41GM281 and 41GM282 at the Gibbons Creek Lignite Mine, Grimes County, Texas. Docu- ment No. 940611. Espey, Huston and Associates, Inc., Austin.

1997 National Register Testing at Site 41LE120, Lee County, Texas. Document No. 970348. Espey, Huston and Associates, Inc., Austin.

1999 Excavations at the Walleye Creek Site (41LE57), Lee County, Texas. Document No. 981670. Espey, Huston and Associates, Inc., Austin.

Rogers, Robert, and Steve Kotter

1995 Archaeological Investigations at the Chesser Site (41LE59), Lee County, Texas. Document No. 950209. Espey, Huston and Associates, Inc., Austin.

Ross, Richard E.

1966 The Upper Rockwall and Glen Hill Sites, Forney Reservoir, Texas. Papers of the Texas Archeological Salvage Project No. 9. The University of Texas at Austin.

Saunders, Joe W., C. S. Mueller-Wille, and David L. Carlson (editors)

1992 An Archeological Survey of the Proposed South Bend Reservoir Area: Young, Stephens, and Throckmorton Counties, Texas. Archeological Surveys No. 6. Archeological Research Laboratory, Texas A\&M University, College Station.

Sayles, E. B.

1935 An Archeological Survey of Texas. Medallion Papers No. 17. Gila Pueblo, Globe, Arizona.

Schroeder, Eric A., Craig A. Weaver, and Glenn T. Goode

1999 Archeological Investigations at the Armstrong Site. Current Archeology in Texas 1(1):12-14. Texas Historical Commission, Austin.

2001 Archeological Testing at Sites 41WM908, 41WM911, and 41BL1092 Along the Williamson County Regional Raw Water Pipeline, Williamson and Bell Counties, Texas. PPA Cultural Resources Report Number 0247. Paul Price Associates, Inc., Austin.

Scott, Ann M., Karl W. Kibler, and Marie E. Blake 2002 National Register Testing of Nine Archeological Sites at Waco Lake, McLennan County, Texas. Reports of Investigations 
No. 132. Prewitt and Associates, Inc., Austin.

Scott, Robert F. IV, and Daniel E. Fox

1982 Excavations at Sites 41LK31/32 and 41LK202 in the Choke Canyon Reservoir, South Texas. Choke Canyon Series: Volume 8. Center for Archaeological Research, The University of Texas at San Antonio.

Sellards, E. H.

1940 Pleistocene Artifacts and Associated Fossils from Bee County, Texas. Bulletin of the Geological Society of America 51:16271658.

1952 Early Man in America: A Study in Prehistory. University of Texas Press, Austin.

Shafer, Harry J.

1963 Test Excavations at the Youngsport Site: A Stratified Terrace Site in Bell County, Texas. Bulletin of the Texas Archeological Society 34:57-81.

1971 Investigations into South Plains Prehistory, West Central Texas. Papers of the Texas Archeological Salvage Project No. 20. The University of Texas at Austin.

Shelby, C. A., M. K. Pieper, and A. C. Wright

1968 Geologic Atlas of Texas, Palestine Sheet. Bureau of Economic Geology, The University of Texas at Austin.

Shum, Raymond W.

1980 The La Paloma Mammoth Site, Kenedy County, Texas. In Papers on the Archaeology of the Texas Coast, edited by Lynn Highley and Thomas R. Hester, pp. 79-104. Special Report No. 11. Center for Archaeological Research, The University of Texas at San Antonio.

Skelton, Duford W.

1977 Archeological Investigations at the Fayette Power Project, Fayette County, Texas. Research Report No. 60. Texas Archeological Survey, The University of Texas at Austin.

Skinner, S. Alan

1971 Prehistoric Settlement of the De Cordova Bend Reservoir, Central Texas. Bulletin of the Texas Archeological Society 42:149269.

Skinner, S. Alan, M. B. Cliff, L. Baird, A. B. Amerson Jr., J. Bennett, A. R. Faust, J. Kaskey,
K. Ludden, M. D. Northern, A. Pitchford, J. Raley, D. G. Shaddox, and D. Shanabrook 1982 The Archaeology and History of Lake Ray Roberts, Vol. 1: Cultural Resources Survey. Cultural Resources Report 82-6. Environmental Consultants, Inc., Dallas.

Smith, James E., II

1993 The Vinson Site (41LT1): A Norteño Focus Indian Village in Limestone County, Texas. Bulletin of the Texas Archeological Society 64:65-162.

Sollberger, J. B., and Thomas R. Hester

1972 The Stonehacker Site: A Review of PreArchaic Manifestations in Texas. Plains Anthropologist 17(58, part 1):326-344.

Sorrow, William M.

1966 The Pecan Springs Site, Bardwell Reservoir, Texas. Papers of the Texas Archeological Salvage Project No. 10. The University of Texas at Austin.

1969 Archeological Investigations at the John Ischy Site: A Burned Rock Midden in Williamson County, Texas. Papers of the Texas Archeological Salvage Project No. 18. The University of Texas at Austin.

Sorrow, William, Harry J. Shafer, And Richard Ross 1967 Excavations at Stillhouse Hollow Reservoir. Papers of the Texas Archeological Salvage Project No. 11. The University of Texas at Austin.

Spearing, Darwin

1991 Roadside Geology of Texas. Mountain Press Publishing Company, Missoula, Montana.

Staley, David P., and John A. Evaskovich 1993 A Cultural Resource Survey for Cap Rock Electric Cooperative Proposed Transmission Lines, Borden, Howard, Martin, and Midland Counties, Texas. Project 695. Mariah and Associates, Inc., Albuquerque.

Standifer, Mary L., and Martha Doty Freeman 1985 Inventory and Assessment of Cultural Resources at the Austin Metro-Tech Center Project, Travis County, Texas. Reports of Investigations No. 47. Prewitt and Associates, Inc., Austin.

Steele, D. Gentry

1986 Analysis of Vertebrate Faunal Remains. in The Clemente and Herminia Hinojosa Site, 41JW8: A Toyah Horizon Campsite in 
Southern Texas, by Stephen L. Black, pp. 108-136. Special Report No. 18. Center for Archaeological Research, The University of Texas at San Antonio.

Steele, D. Gentry, and C. A. Hunter

1986 Analysis of Vertebrate Faunal Remains from 41MC222 and 41MC296, McMullen County, Texas. In The Prehistoric Sites at Choke Canyon Reservoir, South Texas: Results of Phase II Archaeological Investigations, by G. D. Hall, T. R. Hester, and S. L. Black, pp. 452-502. Choke Canyon Series: Volume 10. Center for Archaeological Research, The University of Texas at San Antonio.

Steinbomer, Robert A.

1982 Brickmaking in Texas: A History of the Industry and its Product. A partially complete manuscript submitted to the Texas Historical Commission as result of a Texas Historic Resources Fellowship awarded by the San Antonio Conservation Society and administered by the Texas Architectural Foundation.

Stephenson, Robert L.

1949 Archaeological Survey of Lavon and Garza-Little Elm Reservoirs: A Preliminary Report. Bulletin of the Texas Archeological and Paleontological Society 20:21-62.

1950 Archeological Survey of Garza-Little Elm Reservoir, Denton County, Texas. River Basin Surveys, Austin Office, Smithsonian Institution, Washington.

1952 The Hogge Bridge Site and the Wylie Focus. American Antiquity 17(4):299312 .

1970 Archeological Investigations in the Whitney Reservoir Area, Central Texas. Bulletin of the Texas Archeological Society 41:37-277.

Story, Dee Ann

1985a Adaptive Strategies of Archaic Cultures of the West Gulf Coastal Plain. In Prehistoric Food Production in North America, edited by R. I. Ford, pp. 19-56. Anthropological Papers 75. Museum of Anthropology, University of Michigan, Ann Arbor.

1985b The Walton Site: An Historic Burial in McLennan County, Texas. Central Texas Archeologist 10:66-96.
1990 Cultural History of the Native Americans. In The Archeology and Bioarcheology of the Gulf Coastal Plain, by Dee Ann Story, Janice A. Guy, Barbara A. Burnett, Martha Doty Freeman, Jerome C. Rose, D. Gentry Steele, Ben W. Olive, and Karl J. Reinhard, pp. 163-366. Research Series No. 38. Arkansas Archeological Survey, Fayetteville.

Story, Dee Ann, and Harry J. Shafer

19651964 Excavations at Waco Reservoir, McLennan County, Texas: The Baylor and Britton Sites. Miscellaneous Papers No. 6. Texas Archeological Salvage Project, The University of Texas at Austin.

Suhm, Dee Ann

1957 Excavations at the Smith Rockshelter, Travis County, Texas. Texas Journal of Science 9(1):26-58.

1960 A Review of Central Texas Archeology. Bulletin of the Texas Archeological Society 29:63-107.

Suhm, Dee Ann, Alex D. Krieger, and Edward B. Jelks 1954 An Introductory Handbook of Texas Archeology. Bulletin of the Texas Archeological Society, Vol. 25.

Takac, Paul R.

1991 Underwater Excavations at Spring Lake: A Paleoindian Site in Hays County, Texas. Current Research in the Pleistocene 8:4648.

Taylor, Anna Jean, and Cheryl Lynn Highley

1995 Archeological Investigations at the Loma Sandia Site (41LK28). A Prehistoric Cemetery and Campsite in Live Oak County, Texas, Vols. 1 and 2. Studies in Archeology 20. Texas Archeological Research Laboratory, The University of Texas at Austin.

Tennis, Cynthia L.

2002 Archaeological Investigations at the Last Spanish Colonial Mission Established on the Texas Frontier: Nuestra Señora del Refugio (41RF1), Refugio County, Texas, Volume I, Archaeological Investigations. Archaeological Survey Report No. 315. Center for Archaeological Research, The University of Texas at San Antonio. Archeological Studies Program Report No. 39. Texas Department of Transportation, Environmental Affairs Division, Austin. 
Thoms, Alston V., and Steven W. Ahr

1996 Archaeological Studies at Birch Creek Unit and Yegua Creek Fishing-Access Area, Lake Somerville State Park, Burleson County, Texas, Interim Report, September 1996. Center for Environmental Archaeology, Texas A\&M University, College Station.

Thurmond J. Peter, Martha Doty Freeman, and Susan L. Andrews

1981 A Preliminary Assessment of the Cultural Resources in the Brazos Natural Salt Pollution Control Project, Kent, King, and Stonewall Counties, Texas. Reports of Investigations No. 18. Prewitt and Associates, Inc., Austin.

Tomka, Steve A., Timothy K. Perttula, and Robert J. Hard

1997 Archaeology of the Rio Grande and Central Coastal Plains, Texas: A Planning Document (draft). Archaeological Survey Report No. 266. Center for Archaeological Research, The University of Texas at San Antonio.

Toomey, Rickard S., III, Michael D. Blum, and Salvatore Valastro Jr.

1993 Late Quaternary Climates and Environments of the Edwards Plateau, Texas. Global and Planetary Change 7:299-320.

Treece, Abby C., Christopher Lintz, W. Nicholas Trierweiler, J. Michael Quigg, and Kevin A. Miller

1993a Cultural Resource Investigations in the O. H. Ivie Reservoir, Concho, Coleman, and Runnels Counties, Texas, Volume III: Data Recovery Results from Non-Ceramic Sites. Technical Report No. 346-III. Mariah Associates, Inc., Austin.

1993b Cultural Resource Investigations in the O. H. Ivie Reservoir, Concho, Coleman, and Runnels Counties, Texas, Volume IV: Data Recovery Results from Ceramic Sites. Technical Report No. 346-IV. Mariah Associates, Inc., Austin.

Tunnell, Curtis

1960 Appraisal of the Archeological Resources of Champion Creek Reservoir, Mitchell County, Texas. Report Submitted to the National Park Service by the Texas Archeological Salvage Project, The University of Texas at Austin.
Lithic Specimens from the Adair Steadman Sites in Northwest Texas. Office of the State Archeologist, Special Report 18. Texas Historical Commission, Austin.

1978 The Gibson Lithic Cache from West Texas. Office of the State Archeologist, Report 30. Texas Historical Commission, Austin.

Turner, Ellen Sue, and Thomas R. Hester

1999 A Field Guide to Stone Artifacts of Texas Indians. 3rd ed. Gulf Publishing, Lanham.

Voellinger, Leonard

1985 A Cultural Resources Survey of the Block House Creek Development, Williamson County, Texas. Espey, Huston and Associates, Inc., Austin.

Wade, Mariah F.

1999 Unfolding Native American History: The Entrada of Fr. Manuel de la Cruz and the Bosque-Larios Expedition. Bulletin of the Texas Archeological Society 70:29-48.

Wallace, Ernest, and E. Adamson Hoebel

1985 The Comanches: Lords of the Southern Plains. University of Oklahoma Press, Norman. Ninth Printing.

Walter, Tamra L.

1999 A Preliminary Report of the 1997 TAS Field School Excavations in Area A at Mission Espiritu Santo de Zuniga (41VT11), Victoria County, Texas. Bulletin of the Texas Archeological Society 70:97-121.

Wandsnider, L.

1997 The Roasted and the Boiled: Food Composition and Heat Treatment with Special Emphasis on Pit-Hearth Cooking. Journal of Anthropological Archaeology 16:1-48.

Watt, Frank H.

1953 Pottery Diffusions of the Central Brazos Valley. Central Texas Archeologist 6:57-85.

1978 Radiocarbon Chronology of Sites in the Central Brazos Valley. Bulletin of the Texas Archeological Society 49:111-138.

Weinstein, Richard A.

1992 Archaeology and Paleogeography of the Lower Guadalupe River / San Antonio Bay Region: Cultural Resources Investigations Along the Channel to Victoria, Calhoun and Victoria Counties, Texas. Coastal Environments, Inc., Baton Rouge. 
Weir, Frank A.

1976 The Central Texas Archaic. Ph.D. dissertation, Department of Anthropology, Washington State University, Pullman.

Wendorf, Fred, and James J. Hester

1975 Late Pleistocene Environments of the Southern High Plains. Publication No. 9. Fort Burgwin Research Center, Taos, New Mexico.

Wesolowsky, Al B., Thomas R. Hester, and Douglas R. Brown

1976 Archeological Investigations at the Jetta Court Site (41TV151) Travis County, Texas. Bulletin of the Texas Archeological Society 47:25-87.

Willey, Gordon R., and Philip Phillips

1958 Method and Theory in American Archaeology. University of Chicago Press, Chicago.

Wilson, E. W.

1930 Burnt Rock Mounds of Southwest Texas. Bulletin of the Texas Archaeological and Paleontological Society 2:59-63.

Wilson, Lester

1946 Problematical Pits on East Fork. The Record 5(2):11-12.

Woodall, J. Ned

1967a The Coyote Site. In A Pilot Study of Wichita Indian Archeology and Ethno- history, edited by Robert E. Bell, Edward B. Jelks, and W. W. Newcomb, pp. 15-23. Final Report for National Science Foundation Grant GS-964.

1967b The Upper Tucker Site. In A Pilot Study of Wichita Indian Archeology and Ethnohistory, edited by Robert E. Bell, Edward B. Jelks, and W. W. Newcomb, pp. 3-14. Final Report for National Science Foundation Grant GS-964.

Wormington, H. M.

1957 Ancient Man in North America. Denver Museum of Natural History, Denver, Colorado.

Wulfkuhle, Virginia A.

1986 Investigations into the Prehistory of the Upper Clear Fork of the Brazos River: Fisher and Jones Counties, Texas. Unpublished Master's Thesis, The University of Texas at Austin.

Yedlowski, Joseph L., Kevin J. Shaunessy, David H. Jurney, and J. M. Adovasio

1998 Archaeological Investigations in Support of the Superconducting Super Collider Ellis County, Texas. Archaeology Research Program, Mercyhurst College, Erie.

Young, Bill, and Michael B. Collins

1989 A Cache of Blades with Clovis Affinities from Northeastern Texas. Current Research in the Pleistocene 6:26-28. 
APPENDIX A: Glossary of Technical Terms 

Arrow point: Point used to tip an arrow, which is propelled by a bow.

Biface: Piece of conchoidally fracturing stone that has had flakes removed from both faces to create a tool.

Core: Piece of lithic material from which one or more flakes have been removed.

Dart point: Point used to tip a throwing spear or dart, which is propelled by an atlatl.

Debitage: Debris generated by the removal through percussion or pressure of flakes, chips, and chunks to make stone tools.

Fill section: Introduced fill used to elevate the approaches to a bridge above the surrounding terrain.

Flake: Generally thin piece of conchoidally fracturing stone with a positive bulb of percussion showing that it was removed from the parent piece by percussion or pressure.

Grog: Crushed fired clay added as temper to clay used in making ceramic vessels.

Hammerstone: Rock used as a hammer, for example, in making stone tools, crushing nuts, and so on.

Impact Evaluation: Onsite inspection documenting existing damage or other conditions that may preclude the presence of intact archeological deposits within the project area for a proposed Transportation Activity.

Megafauna: Very large animal.

Metate: Anvil of stone used, usually with a mano, to grind plant parts such as seeds.

Midden: Accumulation of occupational debris, particularly organic remains, burned rocks, or shells.

Projectile point: Inclusive term for arrow and dart points.

Sherd: A piece of broken pottery.

Survey: Fieldwork to locate archeological remains within the project area for a proposed Transportation Activity, including on-foot examination of the surface, shovel testing, and trenching by mechanical means where appropriate. 

APPENDIX B: Letters and Letter Reports for Impact Evaluations and Surveys 

The interim reports for the Impact Evaluations and Surveys are on the CD-ROM, which is included only in selected copies. Authors of the reports were Christopher W. Ringstaff, Patrick McLoughlin, Corey Crawford, Ross C. Fields, Karl W. Kibler, E. Frances Gadus, Stephen M. Thompson, Timothy B. Griffith, and Cory J. Broehm. 
